MARCELO MELO BARROSO

\title{
INFLUENCIA DAS MICRO E MACROPROPRIEDADES DOS LODOS DE ESTAÇÕES DE TRATAMENTO DE ÁGUAS NO DESAGUAMENTO POR LEITO DE DRENAGEM
}

\author{
Tese apresentada à Escola de Engenharia \\ de São Carlos da Universidade de São \\ Paulo, como parte dos requisitos para \\ obtenção do título de Doutor em \\ Hidráulica e Saneamento.
}

ORIENTADOR: Prof. Dr. João Sérgio Cordeiro

São Carlos 



\author{
UNIVERSIDADE DE SÃO PAULO \\ ESCOLA DE ENGENHARIA DE SÃO CARLOS \\ DEPARTAMENTO DE HIDRÁULICA E SANEAMENTO
}

MARCELO MELO BARROSO

INFLUÊNCIA DAS MICRO E MACROPROPRIEDADES DOS LODOS DE ESTAÇÕES DE TRATAMENTO DE ÁGUAS NO DESAGUAMENTO POR LEITO DE DRENAGEM 



\section{Oração de uma camponesa de Madagáscar}

Senhor! Dono das panelas e marmitas! Não posso ser a santa que medita aos vossos pés.

Não posso bordar toalhas para o vosso altar.

Então, que eu seja santa ao pé do meu fogão.

Que o vosso amor esquente a chama que eu acendi

e faça calar minha vontade de gemer a minha miséria.

Eu tenho as mãos de Marta. Mas quero também ter a alma de Maria.

Quando eu lavar o chão, lave, Senhor, os meus pecados.

Quando eu puser na mesa comida, coma também, Senhor, junto conosco.

É ao meu Senhor que eu sirvo, servindo minha família. 



\section{AGRADECIMENTOS}

À Deus pelo milagre da vida, da humanidade e da ciência.

À minha família, meus pais Aristeu e Maria José, aos meus irmãos Marcio, Marcos e Maristela e Adah que compartilharam cada passo de alegria, tristeza, esperança, sonho e trabalho neste longo caminho. À toda minha família, avô Campos, dona Dora, meus tios Reginaldo, Janilson, Naldo, Sheila e Michele que sempre apoiaram e me receberam de braços abertos nas infinitas indas e vindas...

À minha amada Patrícia com seu belo sorriso, sabedoria e companheirismo sempre presente, incentivando e contribuindo inestimavelmente nessa conquista.

Ao Prof. Cordeiro pela orientação, apoio e por ampliar minha visão da vida e da ciência. Pelos valiosos ensinamentos e confiança.

À Cali pela essencial contribuição na realização dessa tese e pela companhia na exploração do vasto mundo do saneamento, do lodo e aos fundamentais amigos do departamento de Hidráulica e Saneamento, Carlos Eugênio "Cabrallll”, Zé Eduardo, André, Cacá, Jeanette, Valmir, Fernando companheiro das madrugadas, Magdalena, Leonídia entre outros talvez não citados, mas valiosos.

Ao Fábio Jacomassi (CCDM/UFSCar), Valter e Helton do DEMA/UFSCar, José da Estação Climatológica pela solícita disposição em contribuir prontamente na realização da presente pesquisa. Ao Professor Dr. Edmundo Esquivel do Departamento de Geotecnia da USP, pelos esclarecimentos e contribuição na aquisição das mantas geotêxteis. A Professora Beth do LPB/USP pela atenção dispensada na realização das análises químicas.

Agradeço ao professor Harry Edmar Schulz pelo apoio e presteza da infraestrutura necessária na confecção final da tese. 
Aos meus irmãos e amigos do GPP/GOUs primordiais no meu crescimento pessoal e profissional presentes nos momentos de "celebração da vida e fé" e que aspiram profissionais comprometidos com a verdade, amor a profissão e ao próximo. Minha eterna gratidão e fraterno amor ao Eduardo, Heltinho, Gustavo, Aderson, Sara, Fátima, João Paulo, Renan, “Jão", Julianita, Aline, Idalíria, Wilson, André e tantos outros...

Aos amigos e corpo docente do Departamento de Engenharia Ambiental da Universidade Federal de Rondônia que apoiaram e permitiram a conclusão dessa tese. Não posso esquecer também dos amigos e companheiros do IBAMA/RO, George, Nancy, Keiti, João Paulo, Renato, Ana, Marta e tantos outros pelo apoio dispensado a tantas viagens, idas e vindas.

Aos amigos de São Carlos, Cardoza, Gian, Eduardo, etc.. e a turma do basquete da USP pela presença e amizade.

Aos meus amigos de longa data espalhados pelo Brasil, pelo Mundo que muito contribuíram, cada um a seu modo, ao meu crescimento pessoal e profissional. Marcelo, Ciro, Mocotó, Helder e Fernando, e tantos outros que passaram ao largo da minha história. 


\section{RESUMO}

BARROSO, M. M. (2007). Influência das Micro e Macropropriedades dos Lodos de Estações de Tratamento de Águas no Desaguamento por Leito de Drenagem. 249p. Tese (Doutorado) Escola de Engenharia de São Carlos, Universidade de São Paulo, São Carlos, 2007.

O estudo dos fatores intervenientes, micro e macropropriedades dos lodos de estação de tratamento de água (ETA), no desaguamento por sistemas naturais, com uso de Leito de Drenagem, constituiu o principal foco desta pesquisa. Assim, ensaios de desaguamento por Leito de Drenagem foram realizados com amostras de lodos de sulfato de alumínio e de cloreto de polialumínio $(\mathrm{PACl})$ e monitoramento das variáveis climáticas. Os resultados comprovaram o desempenho do Leito de Drenagem para redução de volume, da ordem de 80 \% e 90 \% para os lodos de PACl e Sulfato de Alumínio e teor de sólidos final respectivamente de 30 a $90 \%$, sem consumo de energia. Na Fase de Drenagem, independente do tipo e volume de lodo aplicado, a vazão de drenagem foi maior quanto menor o valor da taxa de aplicação de sólidos - TAS $\left(\mathrm{kg} / \mathrm{m}^{2}\right)$ (fração volumétrica de partículas). As variáveis analisadas, teor de sólidos, distribuição de tamanho de partículas, morfologia e composição das partículas entre outros, na massa de lodo bruto e desaguado indicaram diferentes mecanismos de secagem e conseqüente influencia na velocidade de secagem. O uso do Fluxo de massa de água evaporada revelou-se adequado para avaliar a Fase de Secagem. O estudo das micro e macropropriedades do lodo mostram-se decisivos para balisarem pesquisas de desenvolvimento dos sistemas de desaguamento e de reúso dos lodos de ETAs.

Palavras-Chave: Lodo, Estação de tratamento de água, Desaguamento, Sistemas Naturais, Leito de Drenagem, Micro e Macropropriedades, Reologia. 



\begin{abstract}
BARROSO, M. M. (2007). Influence of Micro and Macroproperties of Sludge from Water Treatment Plants in Dewatering by Draining Beds. 249p. Ph. D. Thesis. Engineering School of São Carlos, University of São Paulo, São Carlos, 2007.
\end{abstract}

The study of involved factors, micro and macroproperties of sludge from Water Treatment Plants (WTP) in dewatering by natural systems with the use of Draining Beds is the main focus of this research. For this purpose, dewatering assays by Draining Beds were done with samples from Aluminium Sulphate and Polyaluminium Chloride (PACl) sludge, and monitoring of the climatic variables along the experiments. The results proved the performance of the draining beds in reducing the volume, ranging from 80 to $90 \%$ for the sludges from $\mathrm{PACl}$ and Aluminium Sulphate and the final rate of solids from 30 to $90 \%$, without consuming the energy. In Dewatering Phase, independently of the type and volume of the applied sludge, the bigger the flow of dewatering the lesser the value of the applied rate of solids (TAS, $\mathrm{kg} / \mathrm{m}^{2}$, volumetric fraction of particles). The analised variables, solid rates, distribution of the height of the particles, morphology, and composition of the particles among others, in the mass of the brute and dewatered sludge indicated different mechanisms of drying and consequently influence in the rate of drying. The use of the flow of mass of humidity revealed adequate to evaluate the Drying Phase. The studies of micro and macroproperties of the sludge were decisive to conduct researches of development of dewatering systems and reusing of the sludges from WTP's.

Keywords: Sludge, Water Treatment Plant, Dewatering, Natural Systems, Draining Beds, Micro and Macroproperties, Rheology. 



\section{LISTA DE FIGURAS}

Figura 4.1 - Ilustração de uma ETA convencional e locais de geração dos resíduos ............. 37

Figura 4.2 - Ilustração das frações de água constituintes dos lodos de ETAs........................ 38

Figura 4.3 - Distribuição de tamanho de partículas de lodos de ETAs de três cidades

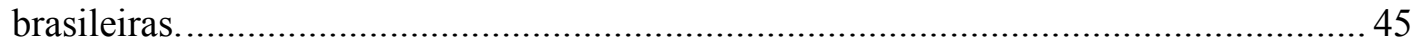

Figura 4.4 - Ilustração esquemática de curva de sedimentação do tipo sazonal.................... 53

Figura 4.5 - Ilustração esquemática das diversas etapas e métodos de tratamento de resíduos

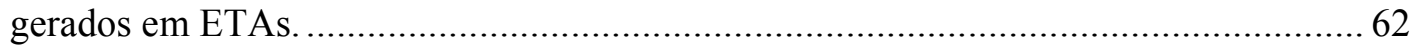

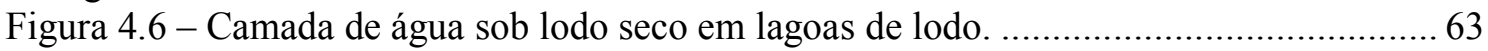

Figura 4.7 - Etapas de desenvolvimento dos sistemas de leitos de secagem......................... 66

Figura 4.8 - Curvas de remoção de água filtrada de sistemas, modificado por Cordeiro 1993 e

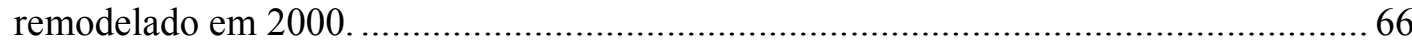

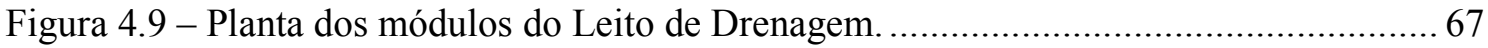

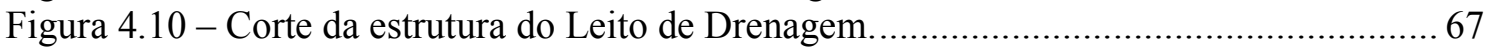

Figura 4.11 - Esquema ilustrativo para medição de permeabilidade no plano...................... 73

Figura 4.12 - Esquema ilustrativo da formação de rede de arcos na superfície dos poros de

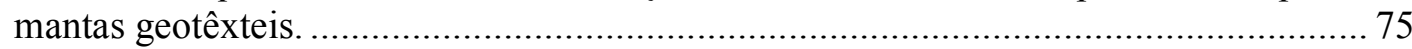

Figura 4.13 - Desenho esquemático do bloqueamento em geotêxtil. ................................ 76

Figura 4.14 - Desenho esquemático do cegamento em geotêxteis. ..................................... 77

Figura 4.15 - Desenho esquemático da colmatação propriamente dita em geotêxteis............ 77

Figura 5.1 - Ilustração esquemática de energia requerida Ei para remoção dos diferentes volumes de frações de água constituintes de lodo de ETAs........................................ 80

Figura 5.2 - Fluxograma dos Procedimentos Metodológicos adotados............................... 82

Figura 5.3 - Ilustração esquemática do ensaio de desaguamento por leito de drenagem e

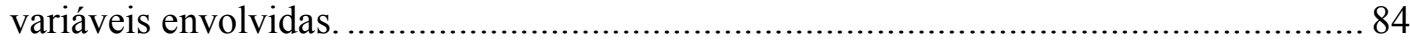

Figura 5.4 - (a) Protótipo de Leito de Drenagem I desenvolvido por Cordeiro (2001). (b) vista geral dos dois protótipos usados nos ensaios de desaguamento, situados na estação

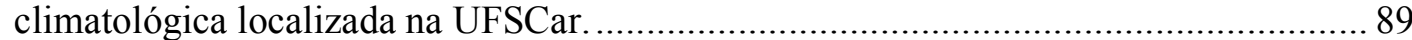

Figura 5.5 - Ilustração do Leito de Drenagem I usado nos ensaios de desaguamento............ 89 Figura 5.6 - Vista do Leito de Drenagem II com volume útil de $10 \mathrm{~L}$ usados nos ensaios de desaguamento na Fase 02 (a) e dos protótipos de acrílicos, Leito de Drenagem III,

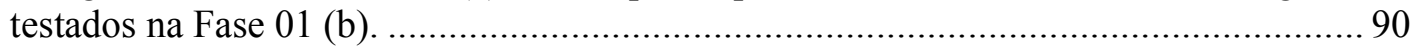

Figura 6.1 - Curva de porcentagem de massa de partículas retida $\mathrm{X}$ abertura de poro em $\mu \mathrm{m}$.

Figura 6.2 - Resultado de sólidos sedimentáveis nos tempos 1 hora, 2 horas, 24 horas e 48 horas para amostras "in natura" e após congelamento (descongelado) de lodo de ETA de sulfato de alumínio.

Figura 6.3 - Variação da vazão de drenagem para lodo de PACl com e sem condicionamento químico (a) e variação do teor de sólidos ST (\%) do resíduo de $\mathrm{PACl}$ retido na manta do leito de drenagem (b)... 114

Figura 6.4 - Curva de sedimentação das amostras de lodos de PACl com e sem adição de polímero aniônico de elevada massa molecular (dosagem $=1 \mathrm{~g} / \mathrm{kg} \mathrm{SST})$.................... 114

Figura 6.5 - Fotografias dos ensaios de desaguamento de lodo de PACl com adição de polímero aniônico de elevada massa molecular $(1 \mathrm{~g} / \mathrm{kg} \mathrm{SST})$ por Leito de Drenagem. (a) lodo de $\mathrm{PACl}$ com polímero aplicado no Leito de Drenagem II. (b) vista da água livre drenada obtida no ensaio preliminar no protótipo de Leito de Drenagem II. (c) vista da água livre drenada do lodo de $\mathrm{PACl}$ com adição de polímero desaguado por Leito de Drenagem I. (d) massa de lodo retida no Leito de Drenagem I. 
Figura 6.6 - Valores de turbidez da água livre drenada das amostras de lodo de PACl com e

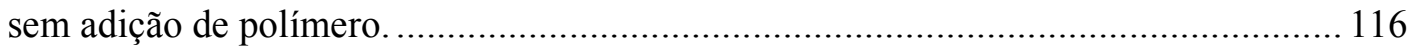

Figura 6.7 - Variação da vazão de drenagem de água livre resultante de ensaio de desaguamento no Leito de Drenagem I em 20/05/2004 (a) e de ensaio realizado no Leito de Drenagem III em acrílico (b) com amostras de lodo de sulfato de alumínio............ 119

Figura 6.8 - Curva de sedimentação dos lodos de sulfato de alumínio e PACl. ................... 122

Figura 6.9 - Variação da vazão de drenagem da água livre (em L/min) para os lodos de sulfato de alumínio e $\mathrm{PACl}$ durante as primeiras 5 horas................................................. 123

Figura 6.10 - Influência da chuva na vazão de drenagem da água livre (em L/s) para os lodos de sulfato de alumínio e PACl durante as primeiras 24 horas.................................... 123

Figura 6.11 - Volume acumulado de drenagem da água livre em (\%) para os lodos de sulfato

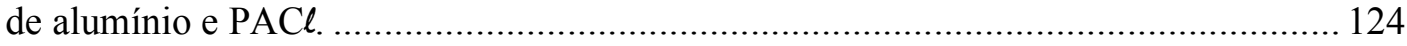

Figura 6.12 - Variação dos valores de volume acumulado de água livre drenada em (\%) e de turbidez durante a fase de drenagem, para as amostras de lodos de sulfato de alumínio (a) e de lodos de $\mathrm{PACl}(\mathrm{b})$. 125

Figura 6.13 - Fotos dos Leitos de Drenagem após 7 dias de aplicação dos lodos de Sulfato de

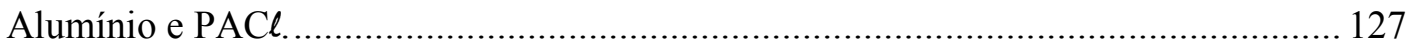

Figura 6.14 - Variação da redução de volume de lodo de Sulfato de alumínio e de PACl... 128

Figura 6.15 - Curva de sedimentação do lodo de PACl aplicado no Ensaio 2 ...................... 129

Figura 6.16 - Variação da vazão de drenagem da água livre em L/min (a) e volume acumulado de água livre drenada (b) proveniente da aplicação de lodo de PACl, Ensaio 2 .......... 130

Figura 6.17 - Variação dos valores de volume acumulado de água livre drenada em (\%) e de turbidez durante a fase de drenagem, para amostra de lodos de PACl, Ensaio 2. ......... 130

Figura 6.18 - Curva de sedimentação dos lodos de sulfato de alumínio e PACl................... 132

Figura 6.19 - Variação da vazão de drenagem de água livre para lodo de sulfato de

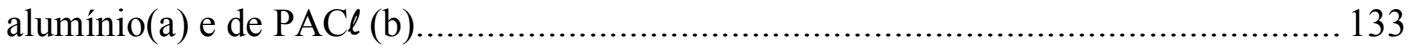

Figura 6.20 - Volume acumulado de drenagem da água livre para os lodos de sulfato de

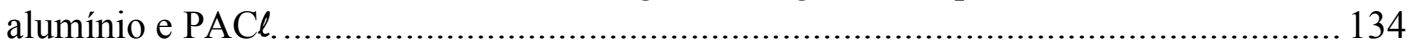

Figura 6.21 - Variação dos valores de volume acumulado de água livre drenada em (\%) e de turbidez durante a fase de drenagem. Para amostras de lodos de sulfato de alumínio (a) e

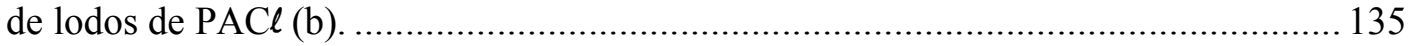

Figura 6.22 - Curva de sedimentação dos lodos de sulfato de alumínio e de PACl.............. 137

Figura 6.23 - Variação da vazão de drenagem da água livre (em L/min) para os lodos de sulfato de alumínio e $\mathrm{PACl}$ durante as primeiras 4 horas............................................. 138

Figura 6.24 - Volume acumulado de drenagem da água livre para os lodos de sulfato de

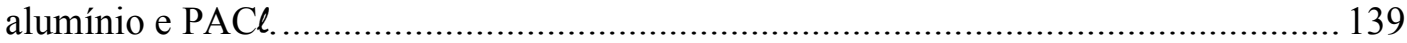

Figura 6.25 - Variação dos valores de volume acumulado de água livre drenada em (\%) e turbidez durante a fase de drenagem. Para amostras de lodos de sulfato de alumínio (a) e

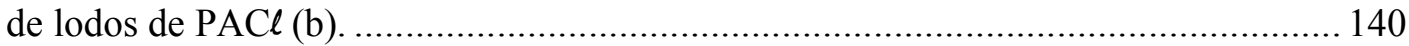

Figura 6.26 - Variação da vazão de drenagem da água livre (em L/min) para os lodos de

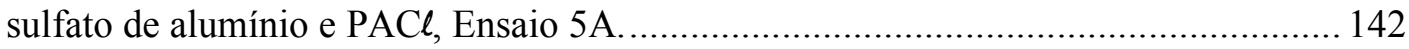

Figura 6.27 - Variação da vazão de drenagem da água livre (em L/min) para os lodos de

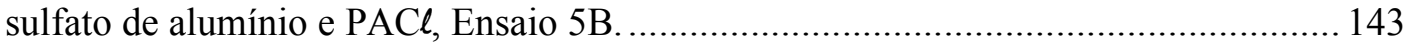

Figura 6.28 - Variação da vazão de drenagem da água livre (em L/min) para os lodos de sulfato de alumínio entre Ensaio 5A e Ensaio 5B.................................................... 143

Figura 6.29 - Variação da vazão de drenagem da água livre (em L/min) para os lodos de PACl

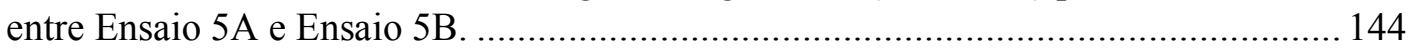


Figura 6.30 - Variação em porcentagem de volume acumulado de drenagem da água livre para os lodos de Sulfato de Alumínio (Ensaios 5A e 5B)........................................ 144

Figura 6.31 - Variação em porcentagem de volume acumulado de drenagem da água livre

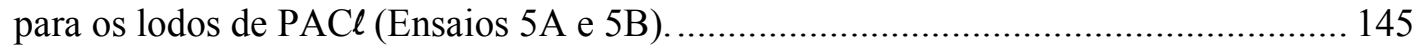

Figura 6.32 - Variação dos valores de volume acumulado de água livre drenada em (\%) e de turbidez para amostras de lodos de sulfato de alumínio (a) e de lodos de $\mathrm{PACl}$ (b), Ensaio $5 \mathrm{~A}$

146

Figura 6.33 - Variação dos valores de volume acumulado de água livre drenada em (\%) e de turbidez para as amostras de lodos de sulfato de alumínio (a) e de lodos de $\mathrm{PACl}$ (b), Ensaio 5B. 146

Figura 6.34 - Variação do teor de sólidos de resíduo de Sulfato de Alumínio retido na manta do leito de drenagem, Ensaios 5A e 5B.... 148

Figura 6.35 - Curvas de sedimentação das amostras de lodos de ETAs de sulfato de alumínio e de PACl usadas nos Ensaios 1, 2, 3 e 4 de desaguamento através de leito de drenagem.

Figura 6.36 - Variação da vazão de drenagem para os Ensaios 1, 2, 3, 4, 5A e 5B.

152 taxa de aplicação de sólidos-TAS em $\left(\mathrm{kg} / \mathrm{m}^{2}\right)$ para os diferentes ensaios realizados com as amostras de lodo de $\mathrm{PACl}$ (a) e de sulfato de alumínio (b).................................... 158

Figura 6.38 - Volume acumulado de água livre drenada dos ensaios de desaguamento com as amostras de lodo de sulfato de alumínio. 160

Figura 6.39 - Volume acumulado de água livre drenada dos ensaios de desaguamento com as amostras de lodo de $\mathrm{PACl}$. 161

Figura 6.40 - Relação entre volume acumulado de água livre drenada e volume aplicado em (\%) para cada ensaio de desaguamento com amostras de lodo de sulfato de alumínio e de PACl, Ensaios 1, 2, 3, 4, 5A e 5B. 162

Figura 6.41 - Ilustração da variação dos valores de turbidez da água drenada de lodos de sulfato de alumínio (a) e lodos de PACl (b). 165

Figura 6.42 - Variação do teor de sólidos para lodos de sulfato de alumínio e de PACl...... 173

Figura 6.43 - Gráficos de curva de secagem e de fluxo de massa de umidade ( $\mathrm{kg}$ água $/ \mathrm{m}^{2}$.dia) para os Ensaios 1, 2, 3, 4, 5A e 5B

Figura 6.44 - Variação da precipitação em $(\mathrm{mm})$ e do teor de sólidos totais $(\% \mathrm{ST})$ para cada ensaio de desaguamento por Leito de Drenagem (Fase de Secagem). ........................ 183

Figura 6.45 - Variação da umidade relativa do ar em (\%) e do teor de sólidos totais $(\% \mathrm{ST})$ para cada ensaio de desaguamento por Leito de Drenagem (Fase de Secagem)........... 184

Figura 6.46 - Variação da insolação (horas) e do teor de sólidos totais (\%ST) para cada ensaio de desaguamento por Leito de Drenagem (Fase de Secagem). .................................. 186

Figura 6.47 - Variação da evaporação $(\mathrm{mm})$ e do teor de sólidos totais $(\% \mathrm{ST})$ para cada ensaio de desaguamento por Leito de Drenagem (Fase de Secagem). ........................ 188

Figura 6.48 - Variação do vento $(\mathrm{m} / \mathrm{s})$ e do teor de sólidos totais $(\% \mathrm{ST})$ para cada ensaio de desaguamento por Leito de Drenagem (Fase de Secagem).

Figura 6.49 - Variação da temperatura do ar $\left({ }^{\circ} \mathrm{C}\right)$ e do teor de sólidos totais $(\% \mathrm{ST})$ para cada ensaio de desaguamento por Leito de Drenagem (Fase de Secagem).

Figura 6.50 - Micrografias obtidas por MEV das amostras de lodo de sulfato de alumínio do Ensaio 4. (a) micrografia de amostra de lodo bruto aplicado no Leito de Drenagem e (b) micrografia de amostra de lodo desaguado (retido na manta geotêxtil).

Figura 6.51 - Resultado da análise de EDS para amostras de lodo de sulfato de alumínio bruto (a) e lodo desaguado, retido no Leito de Drenagem (b). 196 
Figura 6.52 - Micrografias obtidas por MEV das amostras de lodo de PACl do Ensaio 2. (a) micrografia de amostra de lodo bruto aplicado no Leito de Drenagem e (b) micrografia de amostra de lodo desaguado (retido na manta geotêxtil). 198

Figura 6.53 - Resultado da análise de EDS para amostras de lodo de PAC $\ell$ bruto (a) e lodo desaguado (retida no leito de drenagem) (b).

Figura 6.54 - Micrografias da amostra de manta geotêxtil usada. Vista do lado oposto à aplicação de lodo de sulfato de alumínio. (a), (c) e (e) aumento de 50x e (b), (d) e (f) aumento de $250 \mathrm{x}$. 201

Figura 6.55 - Micrografias da amostra de manta geotêxtil virgem, (a), (c) e (e) aumento de $50 \mathrm{x}$ e (b), (d) e (f) aumento de 250x. 203

Figura 6.56 - Difratograma de raios X das amostras de lodo de sulfato de alumínio bruto (LSC1) e lodo desaguado (LSC2). 205

Figura 6.57 - Difratograma de raios X das amostras de lodo de PACl bruto (LPAC1) e lodo desaguado (LPAC2). 207

Figura 6.58 - Curva de distribuição de tamanho de partículas em massa acumulada que passa (\%) por diâmetro de esfera equivalente $(\mu \mathrm{m})$ para amostra bruta de lodo de sulfato de alumínio (a) e amostra de lodo desaguado de sulfato de alumínio (b), (Ensaio 4)....... 211

Figura 6.59 - Curva de distribuição de tamanho de partículas em massa acumulada que passa (\%) por diâmetro de esfera equivalente $(\mu \mathrm{m})$ para amostra bruta de lodo de $\mathrm{PACl}$ (a) e amostra de lodo desaguado de $\mathrm{PACl}$ (Ensaio 4).

Figura 6.60 - Ilustração demonstrando a ação do vento na retirada de camada de umidade subjacente a superfície do lodo desaguado. 223

Figura A1 - Difratograma de raios $\mathrm{X}$ das amostras de lodo de sulfato de alumínio bruto (LSC1) e lodo desaguado (LSC2) e amostras de lodo de PACl bruto (LPAC1) e lodo desaguado (LPAC2) 


\section{LISTA DE TABELAS}

Tabela 4.1 - Teses e dissertações envolvendo resíduos e lodos de ETAs desenvolvidas no Departamento de Hidráulica e Saneamento da EESC-USP. ....................................... 33

Tabela 4.2 - Características dos resíduos de diferentes ETAs no Brasil................................ 39

Tabela 4.3 - Características dos precipitados de sulfato de alumínio e PACl...................... 40

Tabela 4.4 - Micropropriedades e macropropriedades dos resíduos de ETAs ..................... 42

Tabela 4.5 - Densidade do floco e características de filtração de resíduos de várias ETA's. . 50

Tabela 4.5 - Características do lodo de decantador e drenado do Leito de Drenagem de

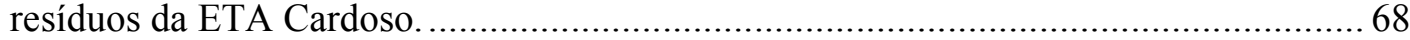

Tabela 4.6 - Características do lodo de decantador da ETA Cardoso e do drenado resultante da

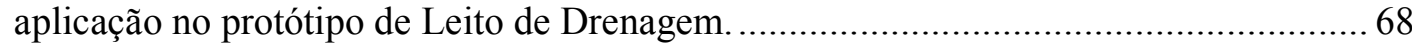

Tabela 4.8 - Comparação entre propriedades gerais dos principais famílias de polímeros usados na fabricação de geotêxteis. ............................................................................ 70

Tabela 5.1 - ETAs envolvidas no desenvolvimento da pesquisa e respectivas ações e

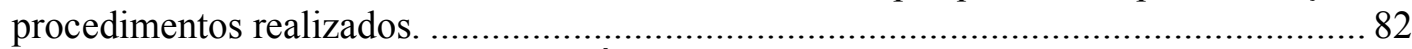

Tabela 5.2 - Estações de Tratamento de Água onde foram coletadas as amostras de lodo de

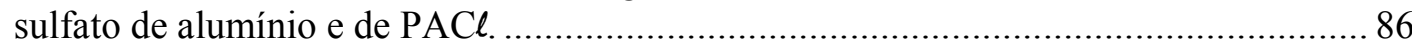

Tabela 5.3 - Características da manta geotêxtil utilizada nos ensaios de desaguamento ........ 90

Tabela 5.4 - Variáveis operacionais e climatológicas monitoradas durante ensaios de

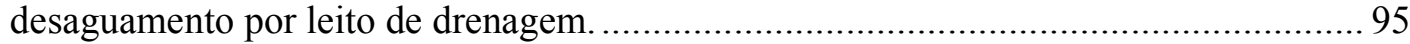

Tabela 5.5 - Variáveis e métodos utilizados para caracterização dos resíduos. .................... 95

Tabela 5.6 - Variáveis e métodos analíticos usados na caracterização da água livre drenada.96

Tabela 5.7 - Micro e macropropriedades e métodos usados na caracterização não tradicional

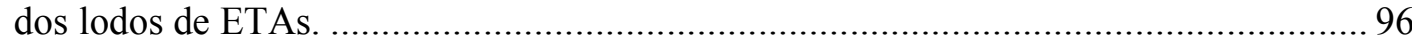

Tabela 5.8 - Procedimentos para determinação de distribuição de tamanho de partículas por fracionamento por filtração seqüencial com uso de membranas. .................................. 99

Tabela 6.1 - Resultado dos ensaios de fracionamento de lodo de sulfato de alumínio, massa de partículas retidas X abertura de poro de membranas de filtração em $\mu \mathrm{m}$..................... 106

Tabela 6.2 - Resultados de determinação de distribuição de tamanho de partículas por SEDIGRAPH e por fracionamento com múltiplas membranas................................. 107

Tabela 6.3 - Resultados dos valores de concentração de carbono orgânico total determinados pelo analisador de COT, nas amostras de lodos de sulfato de alumínio.

Tabela 6.4 - Resultados do ensaio de desaguamento com amostra de lodo de sulfato de alumínio ( $\mathrm{ST}=7,6$ \%) no Leito de Drenagem I...................................................... 118

Tabela 6.5 - Resultados do Ensaio II de desaguamento com amostra de lodo de sulfato de alumínio ( $\mathrm{ST}=2,2 \%$ ) e volume aplicado de 15 litros, Leito de Drenagem I. .............. 118

Tabela 6.6 - Resultados do Ensaio III de desaguamento com amostra de lodo de sulfato de alumínio (ST=2,2 \%) e volume aplicado de 3,5 litros no Leito de Drenagem III. ........ 118

Tabela 6.7 - Realização de coleta e aplicaçde amostras para estudo das características e de

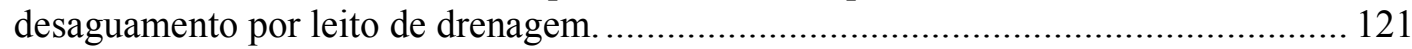

Tabela 6.8 - Caracterização dos resíduos utilizados nos ensaios de desaguamento por leito de drenagem.

Tabela 6.9 - Variação da concentração de sólidos para o resíduo retido no leito de drenagem.

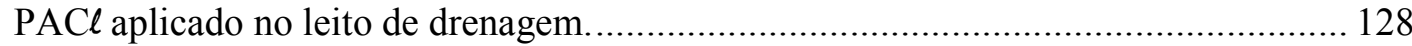

Tabela 6.11 - Variação da concentração de sólidos para o lodo de PACl retido na manta do leito de drenagem, Ensaio 2. 
Tabela 6.12 - Caracterização dos resíduos utilizados nos ensaios de desaguamento por leito de

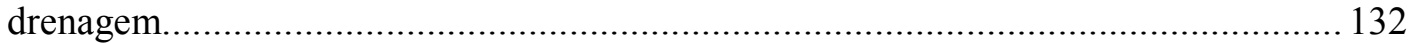

Tabela 6.13 - Variação da concentração de sólidos para o resíduo de Sulfato de Alumínio e $\mathrm{PAC} \ell$ retidos na manta do leito de drenagem, Ensaio 3.............................................. 136

Tabela 6.14 - Caracterização dos resíduos utilizados nos ensaios de desaguamento por leito de

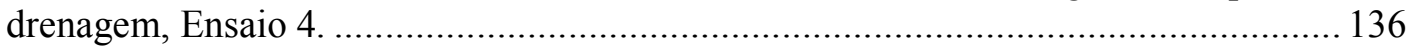

Tabela 6.15 - Resultado do ensaio de sólidos sedimentáveis das amostras de lodo de sulfato de alumínio e de $\mathrm{PACl}$, usadas no ensaio de desaguamento por leito de drenagem...... 136

Tabela 6.16 - Variação da concentração de sólidos para o resíduo de $\mathrm{PACl}$ retido na manta do

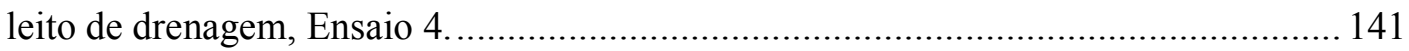

Tabela 6.17 - Caracterização dos lodos usados nos ensaios de desaguamento por leito de drenagem, Ensaios 5A e 5B...................................................................................... 141

Tabela 6.18 - Variação do teor de sólidos para as amostras de lodo desaguado e retido na manta do leito de drenagem (lodo de sulfato de alumínio e de PACl).......................... 147

Tabela 6.19 - Resumo geral das condições de ensaio e resultados dos ensaios de desaguamento de resíduos de ETA. ................................................................ 150

Tabela 6.20 - Quadro geral das velocidades de sedimentação das amostras usadas nos Ensaios

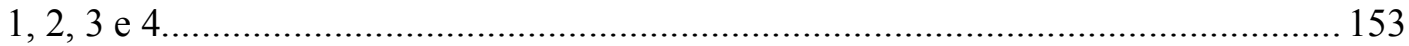

Tabela 6.21 - Valores de vazão de drenagem em ordem decrescente para os lodos de sulfato de alumínio e correspondente taxa de aplicação de sólidos. ..................................... 157

Tabela 6.22 - Valores de vazão de drenagem em ordem decrescente para os lodos de PACl e correspondente taxa de aplicação de sólidos. ........................................................... 157

Tabela 6.23 - Valores de cor aparente (uC), turbidez (uT) e pH nas amostras de água drenada

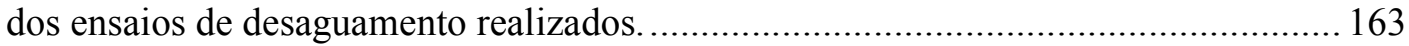

Tabela 6.24 - Valores de concentração de sólidos totais, e composição percentual de sólidos fixos totais e sólidos voláteis totais na água drenada................................................ 166

Tabela 6.25 - Determinação da concentração de metais $(\mathrm{mg} / \mathrm{L})$ nas amostras de lodo bruto e de água livre drenada para os lodos de sulfato de alumínio e de PACl, Ensaios 3 e 4. $\mathrm{PACl}$ 169

Tabela 6.26 - Concentração de DQO e COT em mg/L nas amostras de lodo bruto e de água livre drenado para os Ensaios 3 e 4 realizados com lodo de sulfato de alumínio e de $\mathrm{PACl}$

Tabela 6.27 - Variação de teor de sólidos durante a Fase de Secagem............................... 172

Tabela 6.28 - Valores dos componentes químicos, valor médio em (\% em massa) encontrados para amostras de lodo bruto de sulfato de alumínio, reportados na literatura brasileira.194

Tabela 6.29 - Elementos químicos identificados por EDS nas partículas encontradas na amostra de manta geotêxtil usada nos ensaios de desaguamento de lodo de sulfato de alumínio por Leito de Drenagem. ..................................................................... 202

Tabela 6.30 - Elementos químicos identificados por EDS nas partículas encontradas na amostra de manta geotêxtil virgem (não usada)................................................... 204

Tabela 6.31 - Valores dos componentes químicos, valor médio em (\% em massa) encontrados para lodo de $\mathrm{PACl}$ e sulfato de alumínio (Difração de Raios X)................................. 205

Tabela 6.32 - Valores de distribuição de tamanho de partículas para lodos de sulfato de alumínio e $\mathrm{PACl}$ (bruto e desaguado) e valores correspondentes reportados no Brasil. 214 


\section{LISTA DE ABREVIATURAS E SIGLAS}

ABES

ANA

ALAF

AWWA

ASCE

ASTM

CCDM

CETESB

CONAMA

COT

DAT

DBPs

DQO

ETA

ETEs

EESC

EAA

IBGE

LATAR

LPB

MEV

MON

NMP

NTK

$\mathrm{PACl}$

PROSAB

RMSP

SABESP

SEDIGRAPH

USP

UFSCar
Associação Brasileira de Engenharia Sanitária

Agência Nacional de Águas

Água de Lavagem de Filtros

American Water Works Association

American Society of Civil Engineers

American Society for Testing Materials

Centro de Caracterização e Desenvolvimento de Materiais

Companhia de Tecnologia de Saneamento Ambiental

Conselho Nacional do Meio Ambiente

Carbono Orgânico Total

Decantador de Alta Taxa

Sub-produtos da Desinfecção com cloro

Demanda Química de Oxigênio

Estação de Tratamento de Água

Estação de Tratamento de Esgotos

Escola de Engenharia de São Carlos

Espectroscopia de Absorção Atômica

Instituto Brasileiro de Geografia e Estatística

Laboratório de Tratamento Avançado e Reuso de Águas

Laboratório de Processos Biológicos

Microscópio Eletrônico de Varredura

Matéria Orgânica Natural

Número Mais Provável

Nitrogênio Total Kjeldhal

Cloreto de Polialumínio

Programa de Pesquisa em Saneamento básico

Região Metropolitana de São Paulo

Companhia de Saneamento Básico do Estado de São Paulo

Analisador de Distribuição e Tamanho de Partículas por Sedimentação

Universidade de São Paulo

Universidade Federal de São Carlos 


\section{SUMÁRIO}

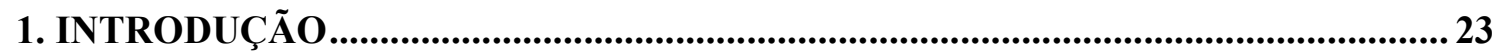

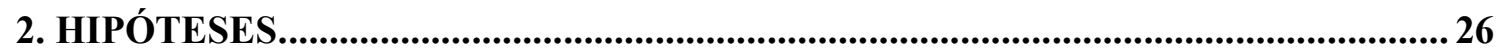

3. OBJETIVOS ……........................................................................................................... 27

4. REVISÃO BIBLIOGRÁFICA .................................................................................28

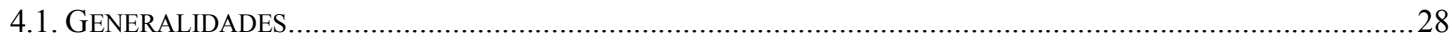

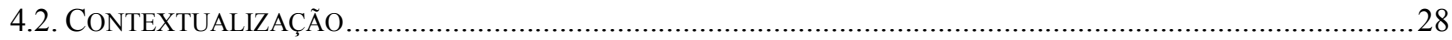

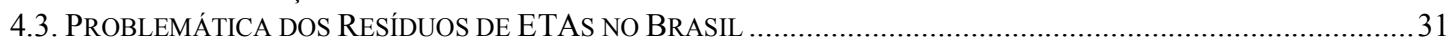

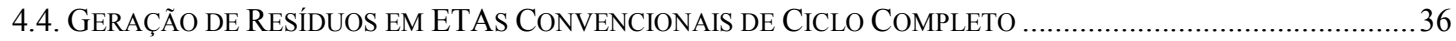

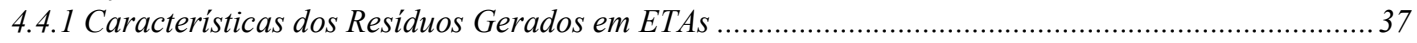

4.4.2 Características dos Resíduos de ETAs: Influência das Condições de Coagulação ........................... 40

4.4.3 Micropropriedades e Macropropriedades de resíduos de ETAs ................................................... 41

4.2.3 Considerações Sobre as Micro e Macropropriedades e Características Reológicas dos Resíduos de

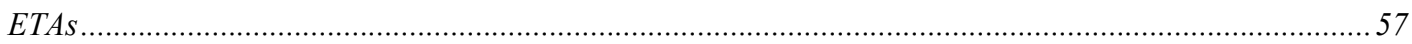

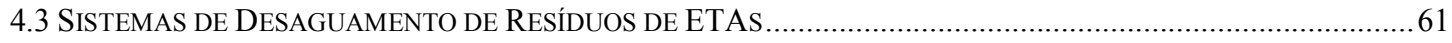

4.3.1 Sistemas naturais de desaguamento - Leito de Drenagem .........................................................6 65

4.6. FundAMENTAÇ̃̃o TEÓRICA No USO DE MANTAS GEOTÊXTEIS. .............................................................69

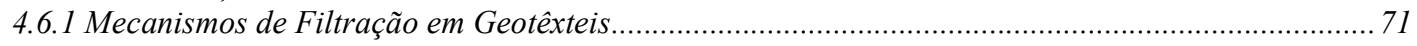

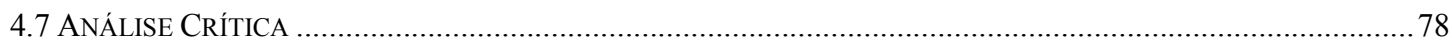

\section{PROCEDIMENTOS METODOLÓGICOS.......................................................................8 8}

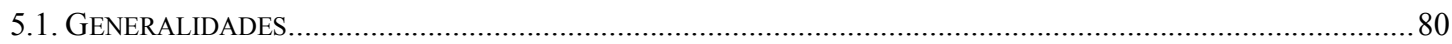

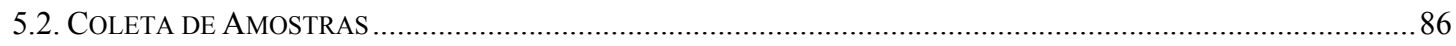

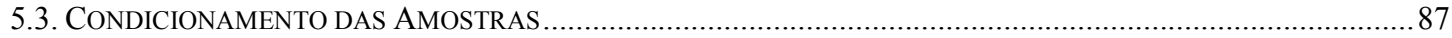

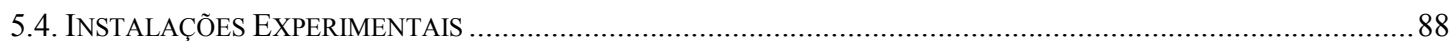

5.5. ENSAIOS DE DESAGUAMENTO POR LEITO DE DRENAGEM (FASE 02) ................................................. 92

5.6 CARACTERIZAÇÃO “TRADICIONAL” DAS AMOSTRAS DE LODO DE ETAS .................................................. 95

5.7. CARACTERIZAÇÃO DA ÁGUA LIVRE DRENADA DOS ENSAIOS DE DESAGUAMENTO POR LEITO DE DRENAGEM

.

5.8. CARACTERIZAÇÃO DAS MICRO E MACROPROPRIEDADES DAS AMOSTRAS DE LODOS DE ETAS ...................96

5.8.1 Sedimentabilidade - Ensaios em Coluna de sedimentação .......................................................96

5.8.2 Determinação das Frações de água do Lodo e ensaios de congelamento .......................................... 97

5.8.3 Determinação de distribuição de tamanho de partículas (Fracionamento e SEDIGRAPH) ..............98

5.8.4 Microscopia Eletrônica de Varredura acoplada a Espectrocopia por Dispersão de Energia de Raios-

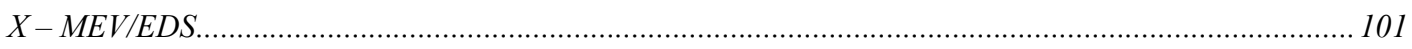

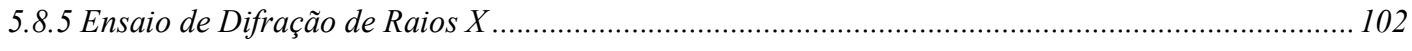

5.8.6 Estudo de Metodologia para Determinação de COT em resíduos de ETAs....................................... 102 
6.1. FASE 01: ESTUDO E DEFINIÇÃO DAS MICRO E MACROPROPRIEDADES E VARIÁVEIS DE CONTROLE USADAS PARA REALIZAÇÃO DE ENSAIOS DE DESAGUAMENTO POR LEITO DE DRENAGEM ....

6.1.2 Ensaios preliminares para definição dos procedimentos operacionais necessários e definição das variáveis de controle

6.2. FASE 02: ENSAIOS DE DESAGUAMENTO COM LODO DE SULFATO DE ALUMÍNIO E DE CLORETO DE POLIALUMINIO (PACl) POR LEITO DE DRENAGEM

6.2.1 Ensaio 1

6.2.2 Ensaio 2 128

6.2.3 Ensaio 3 132

6.2.4 Ensaio 4 136

6.2.5 Ensaio 5 (5A e $5 B$ ) 141

6.3. AVAliaÇÃo CONJUNTA DE DESEMPENHO dOS ENSAIOS DE DESAGUAMENTO COM LODO DE SULFATO DE ALUMÍNIO E DE PACL POR LEITO DE DRENAGEM

6.3.1 Desempenho dos ensaios de desaguamento por Leito de Drenagem com as amostras de lodos de

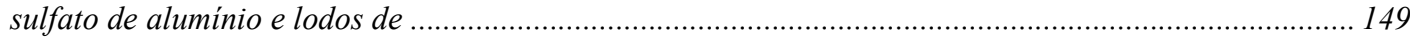

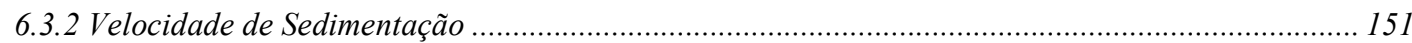

6.3.3 Avaliação do desaguamento por Leito de Drenagem - Fase de Drenagem................................... 154

6.3.4 Avaliação do desaguamento por leito de drenagem - Fase de Secagem .................................... 171

6.3.5 Influência das variáveis climáticas na Fase de Secagem

6.3.6 Avaliação qualitativa dos ensaios de desaguamento por leito de drenagem - micro e macropropriedades.

6.3.7 Considerações e conclusões parciais

6.4. ProposiçÃo: ESCLARECIMENTO SOBRE O DESAGUAMENTO DE LODOS DE ETAS POR SISTEMAS NATURAIS (LEITO DE DRENAGEM) 219 6.5. ANÁLISE CRÍTICA DOS RESULTADOS 225

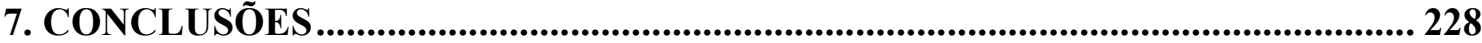

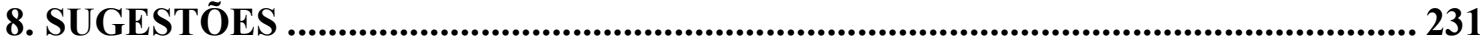

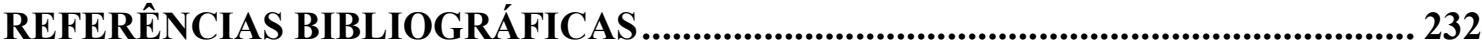

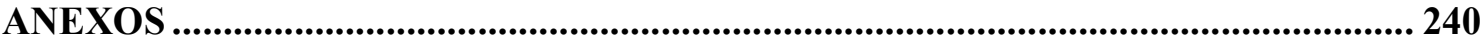




\section{Introdução}

A universalização do saneamento é prerrogativa para obter o desenvolvimento humano, social e econômico. A dinâmica observada na adoção de políticas públicas (Política Nacional do Meio Ambiente de 1981); criação de organismos nacionais, como a Agência Nacional de Águas-ANA e desdobramentos da legislação brasileira, tais como, Lei nº 9433/97 “Política Nacional dos Recursos Hídricos”, Lei no 9605/98 "Lei dos Crimes Ambientais", mostra quão importantes são os problemas relacionados à água.

A necessidade de estabelecer uma Política Nacional de Saneamento Ambiental, a despeito da intensa discussão gerada, pode preencher lacunas na condução da prestação de serviços de saneamento no Brasil. Isto é, define os direitos e deveres dos titulares, das concessionárias e dos usuários. Dessa forma, maior competição, regulação e fiscalização são esperadas para todos os prestadores de serviços, sejam públicos ou privados.

Nesse contexto, a visão integrada das questões gerenciais, técnicas e administrativas torna-se necessária para garantia de sustentabilidade e competitividade às empresas de saneamento, e acima de tudo, qualidade de serviço ao usuário.

Esta pesquisa tem como pressuposto básico, a abordagem sistêmica dos aspectos envolvidos na produção de água potável, particularmente, dos sistemas de tratamento de água tradicionais de ciclo completo.

Nesse sentido, há dois "aspectos" que podem ser destacados: a crescente degradação dos corpos d'água e conseqüente aumento das restrições dos parâmetros de qualidade da água e a preocupação com a geração de resíduos pela indústria da água que estimulam iniciativas e estudos em busca de gerenciamento adequado.

A crescente degradação dos cursos da água devido ao aumento de lançamentos de carga orgânica que associado à formação de subprodutos potencialmente prejudiciais à saúde 
humana pela interação de MON, coagulantes e desinfetantes tem tornado em âmbito mundial e nacional, uma das principais mudanças estratégicas, no tratamento de água.

Tais mudanças, assim como o uso de novos produtos químicos, principalmente coagulantes pré-polimerizados, como por exemplo, cloreto de polialumínio (PACl) e polímeros auxiliares de coagulação e floculação, podem influenciar não apenas nas operações e processos de tratamento de água, como também, a produção e as propriedades físicas e químicas dos resíduos gerados.

Problemas advindos com a geração de resíduos pela indústria da água estimulam estudos em busca de gerenciamento adequado. No Brasil, vale salientar a criação da Rede de Pesquisa formada no âmbito do Edital 01 do Programa de Pesquisa em Saneamento Básico PROSAB, em torno do tema "Técnicas de Tratamento e Despejos Líquidos de Estações de Tratamento de Água", coordenado pelo Departamento de Hidráulica e Saneamento da Escola de Engenharia de São Carlos - USP (REALI, 1999), neste programa buscou-se reunir e sistematizar as informações "criadas" por agentes geradores de conhecimento sobre o tratamento de água e a problemática dos resíduos gerados.

No Brasil, a grande maioria das ETAs lançam seus resíduos indiscriminadamente nos corpos d'água. Estes resíduos são constituídos de fase sólida e fase líquida, sendo a fase liquida subdividida em diferentes frações. A água livre presente no lodo pode representar quantidade apreciável, dependendo da forma de limpeza dos decantadores. A estrutura dos sólidos presentes nos lodos de ETAs é muito complexa e apresenta uma distribuição de tamanho de partículas e estrutura amorfa ou cristalina que podem dificultar a remoção da água livre. Assim, alternativas de redução do volume de lodo produzido nas ETAs é uma questão complexa que merece destaque e pode ser realizada mediante uso e desenvolvimento de sistemas naturais ou mecânicos. 
A remoção natural de água livre dos resíduos de ETAs pode ser realizada por Sistemas Naturais de redução de volume, que são as Lagoas de lodo e os Leitos de secagem. Vale salientar, que no Brasil, o uso de sistemas naturais de tratamento de resíduos de ETAs possui grande potencial de aplicação principalmente pois reúne requisitos de disponibilidade de área, condições climáticas favoráveis e municípios com dificuldades orçamentárias e de formação de recursos humanos.

A tecnologia de leitos de secagem tem sido tradicionalmente utilizada para remoção de água de rejeitos de diversos tipos de tratamento de águas residuárias, e em alguns casos, de abastecimento e vem sendo aplicada praticamente sem mudanças consideráveis em sua concepção e estrutura física. Dentre as evoluções ocorridas nesse sistema, pode-se citar o Leito de Secagem Modificado.

Cordeiro (1993, 2001), estudou a possibilidade de modificação da estrutura tradicional de leito de secagem, com uso de manta de geotêxtil. A evolução do leito possibilitou a redução acentuada do tempo de drenagem da água livre, recebendo a denominação de Leito de Drenagem.

O uso do Leito de Drenagem para desaguamento de lodos de ETAs já é realidade em alguns municípios do estado de São Paulo e tem-se mostrado promissor face aos resultados obtidos em Cordeiro (2001), Achon (2003) e Fontana (2004).

Contudo, ainda é incipiente a compreensão dos mecanismos envolvidos no desaguamento de resíduos de ETAs por do Leito de Drenagem, bem como de que forma as características desses resíduos influenciam no desempenho do desaguamento. A elucidação desses questionamentos concorre para a melhoria e desenvolvimento tecnológico do leito de drenagem e consiste na motivação desta tese. 


\section{Hipóteses}

Durante o desenvolvimento do presente trabalho de Doutorado foram admitidas as seguintes hipóteses:

- O uso de sistemas naturais, particularmente do Leito de Drenagem, é efetivo para o desaguamento de lodos de decantadores provenientes de ETAs que usam diferentes coagulantes (sulfato de alumínio e PACl).

- As características (micro e macropropriedades) dos resíduos de ETAs influenciam no seu desaguamento por sistemas naturais, mais particularmente Leitos de Drenagem;

- As variáveis climáticas influenciam no desempenho do desaguamento de lodos de ETAs por Leito de Drenagem. 


\section{Objetivos}

Avaliação dos mecanismos envolvidos no desaguamento de lodos de decantadores de Estações de Tratamento de Águas por Leito de Drenagem, considerando a influência das micro e macropropriedades e das variáveis climáticas. Para atingir este propósito, foi necessário o cumprimento de objetivos específicos, destacando-se:

Estudo das micro e macropropriedades de lodos gerados nos decantadores de estações de tratamento de águas convencional de ciclo completo que realizam coagulação com uso dos produtos químicos, sulfato de alumínio e cloreto de polialumínio (PACl);

- Estudo e definição de variáveis de controles e procedimentos operacionais para realização de ensaios de desaguamento de lodos de ETAs por Leito de Drenagem;

- Discussão e proposição dos mecanismos que regem o desaguamento de lodo de ETAs por Leito de Drenagem. 


\section{Revisão Bibliográfica}

\subsection{Generalidades}

A apresentação dos aspectos teóricos que fundamentaram a execução desta pesquisa está dividida em três partes, de maneira possibilitar a compreensão clara da tese proposta.

A primeira parte apresenta os aspectos gerais relativos à produção de água potável e conseqüente geração de resíduos, bem como a contextualização do tema proposto no âmbito do Brasil e no Departamento de Hidráulica e Saneamento da EESC-USP.

$\mathrm{Na}$ segunda parte, apresentam-se a evolução histórica do conhecimento das características dos resíduos de ETAs e definições e técnicas de determinação de micro e macropropriedades dos resíduos de ETAs usadas nesta pesquisa. Na seqüência, apresentam-se os aspectos gerais dos sistemas usados no desaguamento dos resíduos de ETAs, com destaque ao desenvolvimento do Leito de Drenagem usado nesta pesquisa.

Por fim, são abordadas pesquisas nas áreas de geotecnia e desenvolvimento de geotêxteis, de maneira a prover o conhecimento correlato e necessário ao desenvolvimento subseqüente da tese. Adicionalmente, apresenta-se uma discussão crítica relativa à apropriação de técnicas de diferentes áreas de conhecimento no desenvolvimento do tema proposto.

\subsection{Contextualização}

Segundo IBGE/DPIS (2000), a indústria de tratamento de água do Brasil produz cerca de $41.10^{6} \mathrm{~m}^{3} /$ dia de água tratada, através de estações de tratamento de água (ETAs) convencionais e não convencionais e tratamento por desinfecção simples. No universo das ETAs existentes, as ETAs convencionais de ciclo completo são responsáveis pela produção de 
cerca de $30,5.10^{6} \mathrm{~m}^{3} /$ dia, ou seja, $93 \%$ da água tratada. As ETAs podem ser vistas como mini fábricas de resíduos, com produção na faixa de 1 a $4 \%$ do volume total de água tratada, que corresponderia à geração de $613.037 \mathrm{~m}^{3} /$ dia de resíduos de ETAs. Este quadro apresentado pela indústria brasileira de água suscita à crescente necessidade de gerenciamento adequado desses resíduos, à medida que aumenta a pressão ambiental no setor.

$\mathrm{Na}$ indústria da água, a matéria prima (água bruta) recebe produtos químicos (coagulantes, cal, cloro etc.) e mediante operações e processos transforma-se em água potabilizada. Como em todo processo industrial de transformação de matéria prima, há geração de resíduos (nos decantadores, água de lavagem dos filtros e lavagem da casa de química) que, via de regra, podem ser tóxicos ao homem e ao meio ambiente.

(Faber ${ }^{1}, 1969$ apud Cordeiro 1993) reporta que o problema dos resíduos de estações de tratamento de água, tem sido objeto de preocupações desde a década de 30, nos Estados Unidos. A partir de trabalho desenvolvido por Herbert Hudson; mas os resultados obtidos não foram publicados. Em 1946, as primeiras preocupações formais começaram a surgir, através da American Water Works Association - AWWA, com a formação do Comitê "E. 5-8 Disposição de Resíduos de Estações de Tratamento de Água e Estações de Abrandamento". $\left(\right.$ Dean $\left.^{2}, 1954\right)$ apud Cordeiro 1993) considera-se a primeira publicação sobre resíduos de estações de tratamento de água convencionais.

Até o final da década de 60, quase nada havia sido divulgado a respeito das características desses resíduos, fator primordial para que se possa avaliar seu impacto no meio ambiente. Ressalta-se, no entanto, que já em Gattes e Mcdermott (1968) inicia-se o estudo das macropropriedades dos resíduos gerados em ETAs.

\footnotetext{
${ }^{1}$ FABER, H. A. (1969). Report on what is knoow - Conference introductory statement. JAWWA, Denver, v. 61, n. 16, p. $542-543$.

${ }^{2}$ DEAN, J. B. (1953). Disposal of waste from filter plants and coagulation basins. JAWWA, Denve, v.45, n. 11. p. $1226-37$, dec.
} 
Os anos 70 caracterizam-se pela participação efetiva da AWWA, na tentativa de equacionar o problema, estabelecendo o programa "Meios de Informação sobre Controle de Poluição de Água, na Indústria da Água", cujo enfoque principal dizia respeito à necessidade de desenvolvimento de conhecimento sobre o assunto. Apesar de haver grande volume de trabalhos realizados nesse período, não houve grande objetividade, em função da ausência de uma coordenação dos mesmos, que permitisse a sistematização dos resultados obtidos (Cordeiro, 1993). As preocupações com as características desses resíduos situaram-se exclusivamente em suas macropropriedades e parâmetros tradicionais de resíduos de outras indústrias. No Brasil, nesse mesmo período é que iniciou as discussões sobre o tema.

A partir dos anos 80, reforça-se o papel da AWWA na discussão do tema e a integração em trabalhos conjuntos com a Europa. O enfoque, agora, se deu na caracterização do lodo, através de suas micropropriedades, tais como: distribuição de tamanho de partículas, composição química e estudo das frações de água. Maior ênfase foi o impacto ambiental causado pelo lançamento desse resíduo, pois o alumínio não era mais considerado um elemento inofensivo à saúde humana e aos organismos aquáticos.

A partir dos anos 90, abriu-se um campo enorme de pesquisas e estudos nesta área Destacaram-se avaliações mais detalhadas sobre os efeitos tóxicos ao meio ambiente causados pelos resíduos de ETAs, assim como das micropropriedades. Realizaram-se trabalhos sobre o gerenciamento dos resíduos, a influência do crescente aumento de matéria orgânica nos mesmos, estudos de recirculação de efluentes clarificados em ETAs e seus efeitos na qualidade da água. Verificaram-se também avanços nos métodos de desaguamento por sistemas mecânicos em detrimento dos sistemas naturais. A publicação de estudos a respeito dos resíduos de ETAs expandiu, além dos EUA e Europa, com diversos trabalhos realizados nos países asiáticos, na África e em alguns países da América Latina, com destaque para o Brasil. Atualmente observa-se que os trabalhos e iniciativas nos EUA e países europeus são 
coordenados e direcionados, enquanto nos demais países as pesquisas, ainda são em sua maioria, dispersos e desarticulados, reflexo da falta de consciência do problema.

\subsection{Problemática dos Resíduos de ETAs no Brasil}

Os primeiros trabalhos de pesquisas desenvolvidos sobre o problema dos resíduos de ETAs tiveram início na década de 70. Almeida (1975) apresentou no Congresso da Associação Brasileira de Engenharia Sanitária - ABES trabalho considerado o primeiro divulgado sobre o tema. Cordeiro, em 1977, no Congresso da ABES, apresentou levantamento inicial sobre o tema, mostrando na época o que já havia sido divulgado em nível mundial.

A primeira dissertação de mestrado sobre o tema foi desenvolvida por Cordeiro (1981) na Escola de Engenharia de São Carlos - USP, a qual apresentou discussão ampla (para a época) sobre caracterização, remoção de água e possíveis utilizações do lodo. Além disso, Cordeiro e Hespanhol (1981) apresentaram resultados dessa pesquisa no XXI Congresso da ABES.

Após esses trabalhos a SABESP (1987) contratou um estudo para busca de soluções para os lodos das ETAs da Região Metropolitana de São Paulo - RMSP. Nesse período cinco ETAs, tratavam $47,6 \mathrm{~m}^{3} / \mathrm{s}$ e o objetivo do trabalho era buscar alternativas para recuperação de águas de lavagem, tratamento e disposição dos resíduos das ETAs. As soluções propostas para a remoção de água foram: centrífugas, filtro-prensa, filtros de esteiras e lagoas de lodo. Apesar disso, esses sistemas nunca foram implantados completamente. Somente nas ETAs Guaraú e Alto da Boa vista foram construídos sistemas de recuperação de água de lavagem de filtros.

Grandin (1992) realizou pesquisa na Escola Politécnica da USP - SP sobre a remoção de água de lodos de ETAs convencionais de ciclo completo, utilizando filtro-prensas. Cordeiro (1993) apresentou a tese de doutorado junto ao programa de Pós Graduação em 
Hidráulica e Saneamento da Escola de Engenharia de São Carlos/USP - SP, cujo título foi: "O problema dos lodos gerados em decantadores de estações de tratamento de água". No trabalho foi elaborado um estudo detalhado sobre o problema, enfocando questões de quantificação, caracterização, remoção de água e os impactos ambientais provocados em cursos d'água. Também foram definidos ensaios para a simulação de filtros- prensa, filtros a vácuo e leitos de secagem.

Após esses estudos houve, no final da década de 90 um acréscimo nas pesquisas sobre o tema. Aspecto importante a ser mencionado foram as mudanças no campo normativo e legislativo, os quais influenciaram e acentuaram a preocupação com o tema.

Barbosa (2000) realizou estudos sobre o impacto de efluentes (lodos) de estações de tratamento de água à biota aquática através de testes de toxicidade. Magalhães (2003) e Morita (2002) estudaram a viabilidade da incorporação de lodo de ETAs em indústrias cerâmicas, enquanto Andrade (2005) desenvolveu estudos de avaliação de impacto ambiental decorrentes da utilização de resíduos do tratamento de água em indústria de cerâmica vermelha. Outros estudos como Carvalho (2000) e Chao (2006) avaliaram a possibilidade de uso dos lodos de ETAs em sistemas de esgotos.

Diante da gama de trabalhos desenvolvidos sobre o tema e o risco de omitir estudos e conseqüentemente injustiças optou-se por apresentar na Tabela 4.1 uma lista de pesquisas, particularmente, realizadas pelo programa de pós-graduação do Departamento de Hidráulica e Saneamento da EESC-USP. 
Tabela 4.1 - Teses e dissertações envolvendo resíduos e lodos de ETAs desenvolvidas no Departamento de Hidráulica e Saneamento da EESC-USP.

Autor

Título do trabalho

Tipo

Cordeiro, J. S. (1981) Disposição, tratabilidade e reuso de estações de tratamento de águas.

Dissertação de

Mestrado

Cordeiro, J. S. (1993) O problema dos lodos gerados em decantadores

de estações de tratamento de águas.

de

Tese
Doutorado

Scalize, P. S. (1997)

Caracterização e clarificação por sedimentação

Dissertação de da água de lavagem de filtros rápidos de Mestrado estações de tratamento de água que utilizam sulfato de alumínio como coagulante primário

Patrizzi, L. J. (1998)

Redução do volume de lodo gerado em decantadores de estações de tratamento de água Dissertação de tradicionais utilizando espessamento por flotação, e por gravidade seguidos de centrifugação.

Souza Filho, A. G. Caracterização e clarificação por sedimentação (1998) da água de lavagem de filtros rápidos de uma

Dissertação de estação de tratamento de água que utiliza cloreto Mestrado férrico como coagulante primário

Barbosa. R. M. (2000)

Avaliação do impacto de efluentes (lodos) de Tese de estações de tratamento de água à biota aquática Doutorado através de testes de toxicidade

Carvalho,E. H. (2000)

Disposição de resíduos gerados nas estações de Tese de tratamento de água em estações de tratamento de Doutorado esgoto com decantação primária

Escobar, R, J. C. Tratamento e recuperação da água de lavagem Tese de (2001) dos filtros de uma estação de filtração direta e Doutorado simulação da disposição dos lodos em estações de tratamento de esgoto

Barroso, M. M. (2002)

Problemática dos metais e sólidos no tratamento

Dissertação de de água (Estação convencional ou de ciclo Mestrado completo) 
Scalize, P. S. (2003) Disposição de resíduos gerados em estações de Tese de tratamento de água em estações de tratamento de Doutorado esgoto

Souza, F. G. C. (2004) Ocorrência de sólidos e metais na água tratada e Dissertação de nos resíduos gerados em ETA convencional de Mestrado ciclo completo com descargas diárias

A necessidade de conhecer melhor o problema tem incentivado pesquisas no intuito de avaliar o potencial tóxico, quantificação e caracterização dos resíduos de ETAs. Ademais, houve pesquisas no sentido de estudar técnicas de remoção de água e lançamento desses resíduos em rede de coleta de esgoto e em estação de tratamento de esgoto. Entre as técnicas de remoção de água, maior destaque se deu para estudos que envolvem sistemas mecânicos com aplicação de condicionantes, principalmente centrífugas em detrimento aos sistemas naturais. Tal aspecto merece reflexão, visto o enorme potencial brasileiro quanto às condições climáticas e disponibilidade de áreas. Nesse sentido, observam-se avanços principalmente quanto ao desenvolvimento de tecnologias alternativas de desaguamento por sistemas naturais, especialmente leitos de secagem tradicionais.

Na prática, os projetos das estações de tratamento de água combinados com tratamento dos resíduos gerados não apresentaram grandes mudanças. Há ainda ações desarticuladas entre os diversos institutos de pesquisas e principalmente quanto à transferência de tecnologia para empresas, municípios e estados.

Pode-se assegurar que no Brasil, menos de 0,5 \% das ETAs possuem sistemas de remoção de água do lodo e/ou recuperação de água de lavagem de filtros e na maioria desses, os operadores citam que existem problemas operacionais.

Nesse sentido, algumas pesquisas foram desenvolvidas por Achon e Cordeiro (2002), utilizando leitos de secagem que foram modificados por Cordeiro (2001), dentro do Programa de Pesquisa em Saneamento Básico - PROSAB. Os resultados obtidos diminuíram o tempo de remoção da água livre, além do drenado possuir boa qualidade, permitindo sua reutilização 
ou recuperação. Ressalta-se que o leito de secagem modificado em Cordeiro (2001) recebeu a denominação de leito de drenagem. O mesmo foi estudado e construído em escala real por Fontana (2004), no município de Cardoso-SP e tem apresentado resultados satisfatórios.

Na ETA - Rio Descoberto e ETA - Pipiripau situadas em Brasília - DF, os sistemas foram projetados como filtração direta e nessas, as águas de lavagem dos filtros são encaminhadas ao adensamento por gravidade e posteriormente para centrífugas para remoção da água livre. Essa água retorna ao adensador e os sólidos são descartados em aterros.

No caso de Cubatão - SP, os órgãos de meio ambiente exigiram soluções para o problema dos resíduos da ETA que trata cerca de $4 \mathrm{~m}^{3} / \mathrm{s}$. Nesse caso foram projetados sistemas de filtros- prensa de esteiras. Em Campinas, Franca, Piracicaba e Ibaté, no estado de São Paulo, e Curitiba, no Paraná construíram, recentemente, sistemas de tratamento de resíduos constituído por adensamento por gravidade e centrífugas, porém praticamente todos apresentam dificuldades operacionais.

Os sistemas de desaguamento de resíduos de ETAs atualmente existentes no Brasil, ainda possuem problemas a serem solucionados, seja na questão operacional ou no descarte dos sólidos após a remoção de água.

Os sólidos resultantes da remoção de água dos resíduos de ETAs podem ser incorporados em concreto, usados em cerâmicas e demais usos. Nesses casos, torna-se necessário aprofundar o conhecimento das micropropriedades desses resíduos, para visualizar potenciais usos.

Por outro lado, Morita et al. (2002) reportam que o órgão ambiental paulista CETESB (Companhia de Tecnologia de Saneamento Ambiental) tem intensificado o controle sobre o lançamento de lodos gerados de ETAs em cursos d'água, forçando a concessionária de saneamento a buscar soluções, com grande ênfase ao tratamento do lodo e relega, em segundo plano, a disposição final. 
Além disso, a constatação de diversos problemas associados à presença de MON e cor na água tratada, tais como: transporte de contaminantes hidrofóbicos orgânicos e inorgânicos e, formação de subprodutos da desinfecção com cloro (DBPs) tem suscitado a prática de coagulação com objetivos múltiplos de remoção de turbidez ou sólidos, de carbono orgânico total (COT) e de precursores de subprodutos da desinfecção com cloro (DBPs). Dessa forma, a intensificação da remoção de cor e matéria orgânica da água bruta podem alterar a produção e as propriedades dos resíduos gerados nas ETAs.

Nesse sentido, a coagulação química, entre os processos e operações unitárias de tratamento de água, merece destaque, pois influencia no desempenho dos processos subseqüentes (floculação-decantação-filtração) (Di Bernardo, 2005), assim como nas características quantitativas e qualitativas dos resíduos gerados.

\subsection{Geração de Resíduos em ETAs Convencionais de Ciclo Completo}

As estações de tratamento de água (ETAs) convencionais de ciclo completo removem partículas finas, em suspensão e em solução, presentes na água, incluindo substâncias húmicas (responsáveis pela cor, COT). Durante o tratamento, aplicam-se produtos químicos que desestabilizam as partículas coloidais e auxiliam a formação de flocos (hidróxidos metálicos) com tamanho suficiente para sua posterior remoção.

A remoção desses flocos é realizada nos decantadores convencionais ou de alta taxa com descarte em regime de batelada e semicontínuo, respectivamente.

Parcela dos flocos que não sedimentam passam aos filtros para clarificação final. Assim, a estação de tratamento de água produz água para abastecimento e gera resíduos na forma de lodos acumulados nos decantadores e água de lavagem dos filtros. Na Figura 4.1 está ilustrado uma ETA convencional de ciclo completo típica e os respectivos locais de geração de resíduos. 


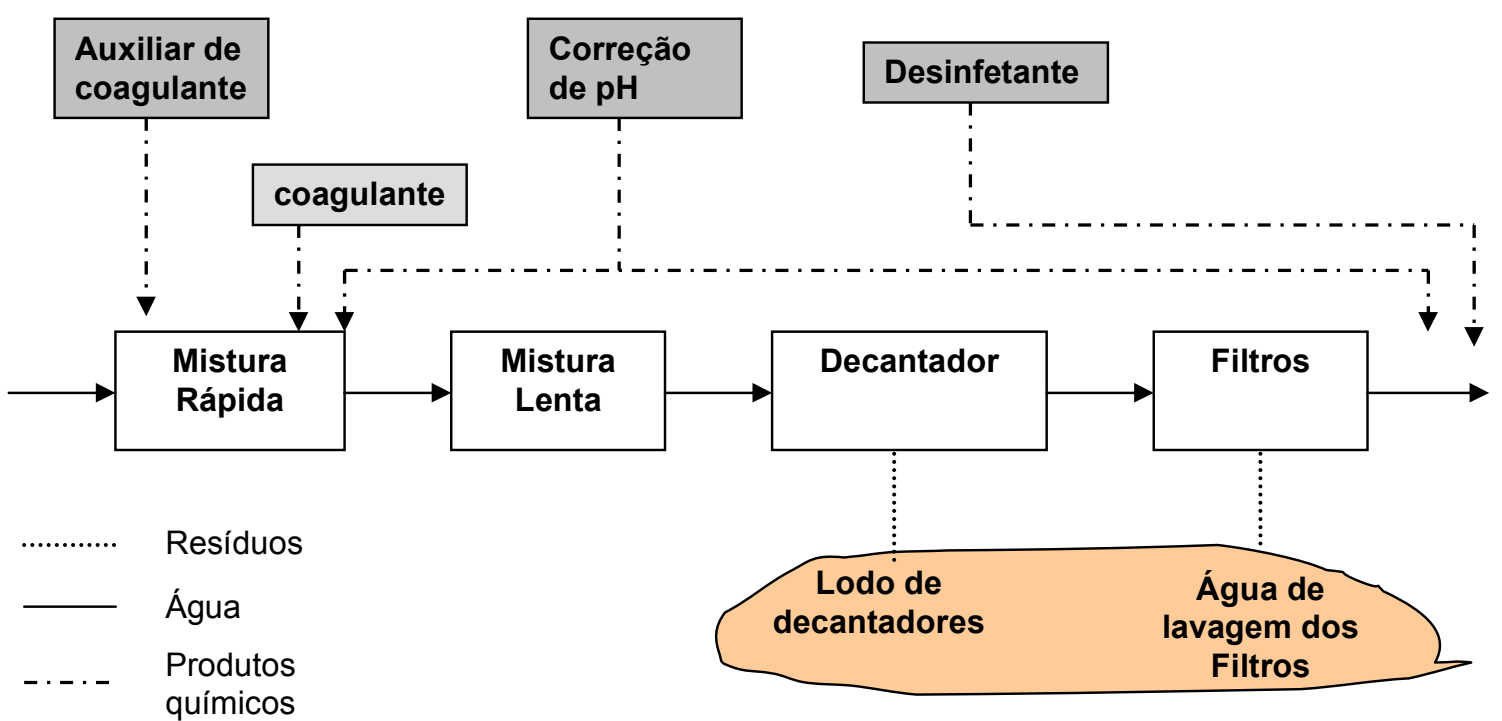

Figura 4.1 - Ilustração de uma ETA convencional e locais de geração dos resíduos.

Fonte: adaptado de Cordeiro (2001).

\subsubsection{Características dos Resíduos Gerados em ETAs}

Os resíduos gerados em ETAs consistem em uma combinação entre fase sólida e líquida. Ressalta-se que a maior parcela destes resíduos corresponde à fase líquida. Assim, as características dos resíduos influenciam a remoção de água e conseqüentemente são essenciais para definir os sistemas de redução de volume e viabilizar seu gerenciamento.

Há diversos modelos que procuram definir as frações de água presentes nos lodos. Vesilind e Hsu (1997); Smollen e Kafaar (1994) apresentam um modelo geral, no qual define os diferentes estados físicos da água, conforme pode ser observado na Figura 4.2:

- Água livre - água não associada aos sólidos e que pode ser facilmente separada por sedimentação gravitacional simples;

- Água intersticial ou capilar - água presente no interior ou intimamente ligada aos flocos. Esta água pode ser liberada quando há quebra do floco, mediante aplicação de força mecânica, tais como centrífugas; 
- Água vicinal - associada às partículas sólidas por virtude da estrutura molecular da água, pontes de hidrogênio;

- Água de hidratação - água quimicamente ligada às partículas sólidas e pode ser liberada somente por destruição termoquímica das partículas.
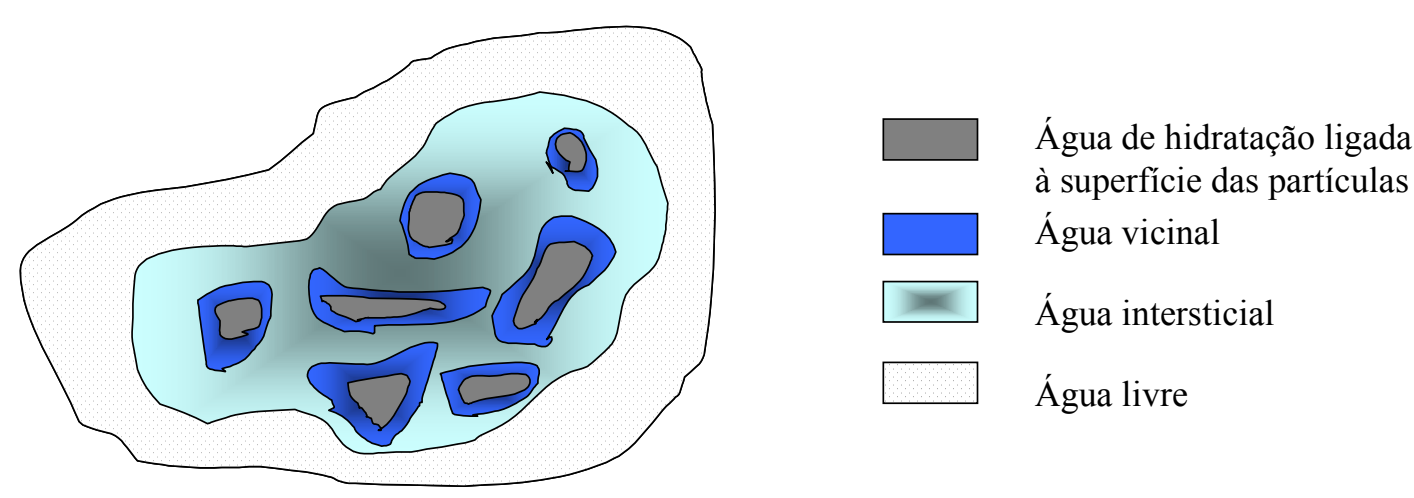

angua intersticial

$\square$ Água livre

Figura 4.2 - Ilustração das frações de água constituintes dos lodos de ETAs.

Fonte: adaptado Smollen e Kafaar (1994).

As quantidades relativas das diferentes frações de água determinam as características de retenção de água dos resíduos e, conseqüente, desempenho dos sistemas de remoção de água (Reali, 1999).

Na composição dos resíduos gerados em ETAs encontram-se metais, sais diversos, plâncton e microrganismos, entre outras substâncias orgânicas e inorgânicas. As partículas presentes na água a ser tratada são basicamente colóides que conferem à mesma, cor e turbidez. Os colóides têm tamanho que varia de $1 \mathrm{~nm}\left(1 \mathrm{~nm}=10^{-6} \mathrm{~mm}\right)$ e $1 \mu \mathrm{m}\left(1 \mu \mathrm{m}=10^{-3} \mathrm{~mm}\right)$ e são incorporados aos flocos. Essa característica faz com que os lodos tenham dificuldade de remoção da água livre, mediante espessamento e desaguamento (Cordeiro, 2001).

Os metais, em especial o alumínio, exercem papel de destaque face suas potenciais ações tóxicas, além de possíveis efeitos positivos e negativos nas técnicas de tratamento, disposição e reutilização desses resíduos. Outro aspecto é que, os metais podem estar 
concentrados por complexantes, principalmente orgânicos, presentes na fase líquida do lodo, Gutekunst $^{3}$ apud ASCE e AWWA (1996).

Segundo Cordeiro (1993), a caracterização dos resíduos de ETAs se torna fundamental para avaliação de possível impacto ambiental, métodos de remoção de água e disposição final. ASCE e AWWA (1996) ressaltam que as características químicas interferem mais na disposição final e nos estudos de reaproveitamento, que nos processos de manejo, adensamento e desaguamento.

Na Tabela 4.2 as características dos resíduos de decantadores e de água de lavagem de filtros (ALAF) de diferentes ETAs brasileiras e adicionalmente comparadas com os parâmetros de lançamento estabelecidos pela Resolução CONAMA 357/05.

Tabela 4.2 - Características dos resíduos de diferentes ETAs no Brasil.

\begin{tabular}{|c|c|c|c|c|c|c|c|}
\hline \multirow{2}{*}{ Parâmetros } & \multirow{2}{*}{ Unidade } & \multirow{2}{*}{ CONAMA 357/05 } & \multicolumn{3}{|c|}{ Lodo de decantadores } & \multicolumn{2}{|c|}{$\begin{array}{c}\text { Água de lavagem } \\
\text { de filtros }\end{array}$} \\
\hline & & & $\begin{array}{l}\text { ETA 1 }^{(\text {a) }} \\
\text { (DC) }\end{array}$ & $\begin{array}{c}\mathrm{ETA}^{(\mathrm{b})} \\
\text { (DC) }\end{array}$ & 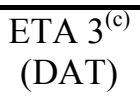 & ETA $1^{(\mathrm{d})}$ & ETA $3^{(\mathrm{e})}$ \\
\hline $\mathrm{pH}$ & - & $5-9$ & 7.2 & 7.4 & 8.93 & 6.9 & $8.4-9.2$ \\
\hline $\begin{array}{c}\text { sólidos } \\
\text { sedimentáveis }\end{array}$ & $\mathrm{ml} / \mathrm{L}$ & 1 & - & - & & 3.4 & - \\
\hline sólidos suspensos & $\mathrm{mg} / \mathrm{L}$ & - & 26520 & 15330 & 775 & 59 & $200-440$ \\
\hline Alumínio & $\mathrm{mg} / \mathrm{L}$ & - & 11100 & 30 & 2.16 & 0.3 & - \\
\hline Arsênio & $\mathrm{mg} / \mathrm{L}$ & 0.5 & - & - & - & - & - \\
\hline Cádmio & $\mathrm{mg} / \mathrm{L}$ & 0.2 & 0.02 & 0.27 & ND & ND & ND \\
\hline Chumbo & $\mathrm{mg} / \mathrm{L}$ & 0.5 & 1.6 & 1.06 & ND & ND & $0-1.5$ \\
\hline Cobre dissolvido & $\mathrm{mg} / \mathrm{L}$ & 1 & $2.06 *$ & $0.91 *$ & $1.7^{*}$ & $0.06^{*}$ & - \\
\hline Cromo VI & $\mathrm{mg} / \mathrm{L}$ & 0.5 & \multirow{2}{*}{$1.58 *$} & \multirow{2}{*}{$0.86^{*}$} & \multirow{2}{*}{$0.19 *$} & \multirow{2}{*}{ ND } & \multirow{2}{*}{$0-0.56^{*}$} \\
\hline Cromo III & $\mathrm{mg} / \mathrm{L}$ & 2 & & & & & \\
\hline Ferro solúvel & $\mathrm{mg} / \mathrm{L}$ & 15 & 5000 & 4200 & 214 & 6.9 & $8.7-31.9$ \\
\hline Mercúrio total & $\mathrm{mg} / \mathrm{L}$ & 0.01 & - & - & - & - & - \\
\hline Níquel total & $\mathrm{mg} / \mathrm{L}$ & 2 & 1.8 & 1.16 & ND & ND & $0-0.01$ \\
\hline Prata total & $\mathrm{mg} / \mathrm{L}$ & 0.1 & - & - & - & - & - \\
\hline Zinco total & $\mathrm{mg} / \mathrm{L}$ & 5 & 4.25 & 48.53 & 0.1 & 0.64 & $0-0.01$ \\
\hline
\end{tabular}

a: DC - Lodo de decantador convencional (sulfato de alumínio como coagulante). Fonte:Barroso e Cordeiro (2001)

b: DC - Lodo de decantador convencional (utiliza cloreto férrico como coagulante). Fonte: Barroso e Cordeiro (2001).

${ }^{3}$ GUTEKUNST, B.; HAHN, H.H. (1983). Investigation to reduce heavy metal concentration in municipal sludges with the aid of complexing substances. BMFT Research Report, 3:158, Karlsruhe Univ., West Germany. 
c: DAT - Lodo de decantador de alta taxa com descarga periódica (utiliza cloreto férrico como coagulante). Fonte: Barroso e Cordeiro (2001).

d: Água de lavagem de filtros de ETA que utiliza Sulfato de Alumínio (Filtração com taxa constante). Fonte: Di Bernardo et al. (1999). ND - Não detectado

e: ETA convencional alta taxa (utiliza cloreto férrico como coagulante). Fonte: Souza (2004).

*cromo total; ferro total; manganês total, cobre total.

\subsubsection{Características dos Resíduos de ETAs: Influência das Condições de Coagulação}

Cornwell et al. (1987) citam três variáveis; mecanismo predominante na coagulação, teor de matéria orgânica e a quantidade de sólidos em suspensão da água bruta, que afetam as características físico-químicas e, mais particularmente, a capacidade de desaguamento dos resíduos gerados em ETAs. Acrescenta-se, também, a influência pelo uso de novos coagulantes como PACl.

Vários pesquisadores têm investigado as características de desaguamento dos resíduos de ETAs. Não obstante, poucos relacionam as condições de água bruta e de coagulação (pH, turbidez e dosagem de coagulante) com as características dos resíduos.

Van Benschoten e Edzwald (1990) realizaram estudos de coagulação de substâncias húmicas (ácidos fúlvicos) e usaram coagulantes diferentes, sulfato de alumínio e cloreto de polialumínio (PACl), como resultado houve formação de precipitados (resíduos) distintos, conforme pode ser observado na Tabela 4.3.

Tabela 4.3 - Características dos precipitados de sulfato de alumínio e PACl.

\begin{tabular}{l|l|l}
\hline Características & Sulfato de alumínio & PACl \\
\hline Aspecto, aparência & estrutura porosa, gelatinoso & $\begin{array}{l}\text { coalizão de subunidades poliméricas } \\
\text { intactas. }\end{array}$ \\
\hline Tamanho & 25 a $100 \mu \mathrm{m}$ & $<25 \mu \mathrm{m}$ \\
\hline Carga & carga positiva & carga mais positiva \\
\hline $\begin{array}{l}\text { Redissolvido a pH 4 } \\
\text { (espécie Al resultante) }\end{array}$ & $\begin{array}{l}\text { predomina espécies monoméricas } \\
\text { de Al }\end{array}$ & $90 \%$ de espécies polímericas de Al \\
\hline
\end{tabular}
Obs: Extraído de Van BENSCHOTEN e EDZWALD (1990)

Dulin e Knocke (1989) avaliaram como as características dos resíduos de ETAs são afetadas pela incorporação de carbono orgânico via coagulação. Os resultados indicaram claramente que um aumento na concentração de carbono orgânico específico no lodo 
(quantificado pela relação $\mathrm{COT} / \mathrm{Al}$ ) prejudicou significativamente as características de desaguamento. Os autores reportaram que o aumento da concentração de matéria orgânica incorporada no floco (resíduo), torna-o menos denso, diminue a taxa de desaguamento e a concentração final de sólidos.

No Brasil, Grandin (1992) estudou o desaguamento por filtro-prensa de placas e observou que os resíduos de ETAs podem atingir concentração final de sólidos de até aproximadamente $25 \%$, com uso de polímeros. Para resíduos provenientes de água com elevada concentração de matéria orgânica pode-se obter apenas 15 \%.

Por outro lado, existe pouca informação sobre possíveis correlações entre as características de desaguamento de resíduos de diferentes coagulantes, a exemplo do cloreto de polialumínio $(\mathrm{PACl})$ e as propriedades fundamentais do lodo gerado.

\subsubsection{Micropropriedades e Macropropriedades de resíduos de ETAs}

As características tidas como tradicionais na área do saneamento ambiental são fundamentais na definição do potencial poluidor e disposição final dos resíduos de ETAs. Todavia, deve ser acrescida a avaliação de variáveis não tradicionais, que permitam a visão mais abrangente das características dos resíduos de ETAs. Estas variáveis não tradicionais estão contidas nas micropropriedades e macropropriedades propostas inicialmente por Knocke e Wakeland (1983) e melhor desenvolvidas por Dharmappa et al. (1997). Outro aspecto importante reside na reologia dos lodos, destacadamente como subsídio ao transporte de lodo.

As micropropriedades definem as características intrínsecas do lodo, e podem ser tratadas como características de suspensão, enquanto, as macropropriedades descrevem as características relativas à tratabilidade dos resíduos e são dependentes das micropropriedades. Dharmappa et al. (1997) reportam as principais micropropriedades e macropropriedades consideradas na caracterização de resíduos de ETAs, conforme listado na Tabela 4.4. 
Tabela 4.4 - Micropropriedades e macropropriedades dos resíduos de ETAs

\begin{tabular}{l|l}
\hline \multicolumn{1}{c}{ Micropropriedades } & \multicolumn{1}{c}{ Macropropriedades } \\
\hline Distribuição e tamanho dos flocos & Velocidade de sedimentação \\
\hline Estrutura/forma dos flocos & Flotabilidade \\
\hline Tensão de cisalhamento do floco & Centrifugabilidade \\
\hline Densidade & Velocidade de drenagem em lagoas \\
\hline Concentração de sólidos & Resistência específica \\
\hline Viscosidade e temperatura & Tempo de filtração \\
\hline Tensão superficial & Velocidade de drenagem no solo \\
\hline "Frações" de água & Tempo de sucção por capilaridade \\
\hline Composição química* & Compressibilidade \\
\hline Concentração de matéria orgânica* & Lixiviação \\
\hline pH e alcalinidade* & Força cisalhante \\
\hline Carga das partículas & \\
\hline
\end{tabular}

Fonte: Dharmappa et al. (1997).

* Caracterização da avaliação do potencial poluidor de resíduos de ETAs

As micropropriedades e macropropriedades devem ser determinadas e avaliadas para permitir a tomada de decisões quanto ao processo de remoção de água e aproveitamento dos resíduos de ETAs. Esta avaliação deve ser feita com observação da abordagem a que se remete.

Deve-se salientar que as propriedades importantes para estudos de remoção de água por sistemas naturais podem diferir, enormemente, daquelas usadas em estudos por sistemas mecânicos de remoção. Acrescentam-se ainda, diferenças substanciais entre as diversas tecnologias de tratamento que compõem os sistemas mecânicos ou naturais de desaguamento.

Tais considerações são importantes para reduzir o ônus e o tempo necessário, para um determinado estudo de tratabilidade de resíduos de ETAs.

Nas seções subseqüentes 4.4.3.1 e 4.4.3.2 são apresentadas as principais micro e macropropriedades usadas para caracterização dos resíduos de ETAs. 


\subsubsection{Micropropriedades dos resíduos de ETAs}

\section{Distribuição de Tamanho de partículas}

A avaliação dessa propriedade pode ser realizada sob dois prismas. O primeiro referese ao reportado por Lawler (1997), em que no tratamento de água, as unidades de coagulação e floculação são projetadas para promover mudanças na distribuição do tamanho de partículas e assim favorecer a remoção por sedimentação/flotação e filtração, e estão mais relacionadas com tamanho de partículas floculentas. Num segundo momento estão as partículas floculentas depositadas na forma de lodo de decantadores/flotadores e ALAF em que o tamanho dos flocos, mas principalmente das partículas "sólidas", é preponderante ao gerenciamento dos resíduos de ETA, (Santos et al., 2004).

O conhecimento da forma e distribuição de tamanho das partículas dos resíduos é de fundamental importância para os estudos de redução de volume por meio da remoção de água (desaguamento e secagem) e, mais particularmente, para definição de processos e equipamentos para o desaguamento.

Segundo Santos et al. (2004), muitos dos contaminantes encontrados em água e esgoto são partículas ou serão transformados em partículas antes de sua remoção final. As operações e processos unitários usados no saneamento são influenciados pela distribuição de tamanho das partículas, de modo que, seja em operações ou processos de separação sólido-líquido, seja na degradação biológica de matéria orgânica, o conhecimento da distribuição de tamanho de partículas pode contribuir para a escolha e o aperfeiçoamento das tecnologias de tratamento e para a adoção de procedimentos operacionais apropriados.

O uso e conhecimento dessas características em sistemas de desaguamento de lodos de ETAs, particularmente sistemas naturais de desaguamento, pode favorecer na melhor definição dos parâmetros de dosagem de condicionantes, porosidade de membranas filtrantes ou mantas geotexteis (leito de drenagem). 
As partículas em suspensão constituintes dos lodos de ETAs são estruturas tridimensionais, irregulares, polidispersas (de vários tamanhos) e com diferentes propriedades físico-químicas (Santos et al. 2004).

Dentre as principais propriedades das partículas, a forma surge como uma importante fonte de interferência na determinação de tamanho de partículas. Dependendo da propriedade analisada, partículas de formas distintas podem ser representadas por um mesmo valor de diâmetro (mesma esfera equivalente) ou por diâmetros diferentes (diferentes esferas equivalentes).

Lawler (1997) e Feitz et al. (2001) citam que o uso do diâmetro de esfera equivalente de mesma área superficial pode ser mais adequado, para a avaliação das características de desaguamento de um lodo.

Knocke et al. (1980) citam que resíduos não condicionados de ETAs originários de tratamento com sulfato de alumínio possuem tamanho médio dos flocos geralmente inferiores a $20 \mu \mathrm{m}$. Além disso, foi observado que qualquer mudança na distribuição do tamanho da partícula pode influenciar a resistência específica à filtração e à taxa de desaguamento dos resíduos de ETAs.

No Brasil, Cordeiro (2001) apresentou a distribuição de tamanho de partículas de resíduos de ETAs de três cidades e observou que entre 45\% e 70\% das partículas são menores que $10 \mu \mathrm{m}$, conforme pode ser observado na Figura 4.3.

Morita et al. (2002) estudaram a incorporação de resíduo de ETA em blocos cerâmicos e verificaram que de $60 \%$ a $68 \%$ das partículas apresentaram diâmetro compreendido entre 2 e $20 \mu \mathrm{m}$. Nesse estudo foi usado um analisador de partículas.

Oliveira et al. (2004) determinaram a distribuição de tamanho de partículas para lodos da ETA Campos de Goytacases/RJ, sem mencionar o tipo de coagulante originário, e encontraram os seguintes resultados, $45 \%$ das partículas $<2 \mu \mathrm{m}, 41 \%$ compreendido entre 2 
e $60 \mu \mathrm{m}$ e cerca de $14 \%$ das partículas compreendido entre 60 e $600 \mu \mathrm{m}$. Ressalta-se ainda que a metodologia consistiu na combinação de peneiramento e sedimentação e que a mesma pode apresentar problemas de tendência a aglomeraçào, possivelmente pela ocorrência de óxido de titânio. Estes aspectos podem demandar o uso de análises baseados em sedimentação com adição de defloculante.

Os problemas relacionados com as diferentes técnicas de determinação da distribuição de tamanho de partículas e tipos de expressão de resultados sugerem cautela para afirmações conclusivas.

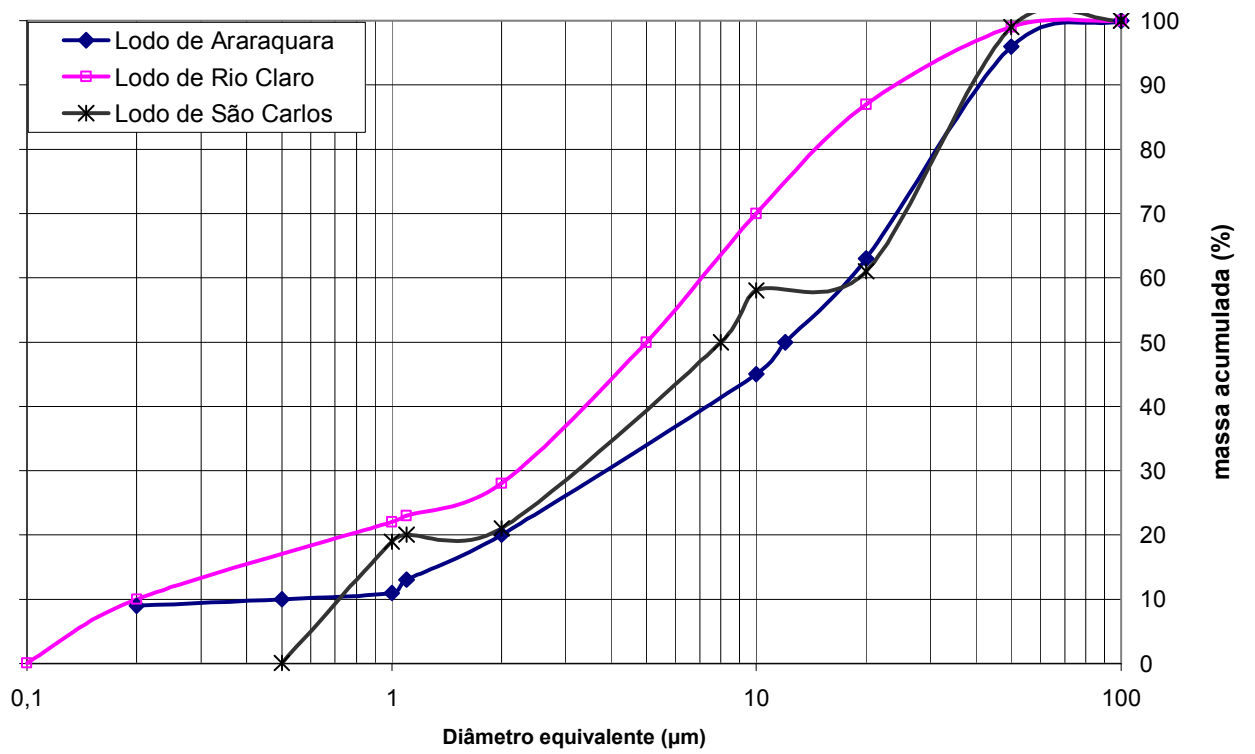

Figura 4.3 - Distribuição de tamanho de partículas de lodos de ETAs de três cidades brasileiras.

Fonte: Cordeiro (2001)

Segundo Santos et al. (2004), as técnicas de determinação de tamanho de partículas podem ser divididas em dois grupos: com e sem fracionamento da amostra. Nas técnicas com fracionamento, as partículas são removidas da amostra por faixas (frações) de tamanho, obtida após sucessivas etapas de separação.

Quando do uso de fracionamento por filtração em membranas ou papel de filtro, o tamanho das partículas é relacionado ao diâmetro (abertura) do poro, ou seja, os resultados são expressos em esfera de diâmetro igual à abertura do poro. 
Nas técnicas sem fracionamento, por sua vez, não é aplicado nenhum mecanismo de separação física, conseqüentemente as frações de tamanho, presentes na amostra, são determinadas por uma única medição.

A escolha da técnica adequada para se efetuar a análise granulométrica de um determinado material vai depender do tamanho das partículas ali presentes, da natureza da amostra (seca, dissolvida ou em suspensão) e finalidade da informação.

As partículas podem ter várias formas, que influenciam determinadas propriedades, tais como fluidez, empacotamento e interação com fluidos. Logo, a medição de tamanho de uma mesma partícula por diferentes técnicas pode dar valores diferentes, à medida que a forma dessa partícula se distancia de uma esfera, daí a razão de se aplicarem fatores de correção para transformar as medidas obtidas de uma técnica para outra e vice-versa.

\section{Análise morfológica e qualitativa das partículas constituintes do lodo por Microscopia Eletrônica de Varredura Acoplada a Espectroscopia por Dispersão de Energia de Raios- X (MEV/EDS)}

A análise da superfície, arranjo físico e/ou morfologia das partículas constituintes de lodos de ETAs pode ser realizado por Microscopia Eletrônica de Varredura, bem como a análise qualitativa dos elementos que compõem o lodo, via Espectroscopia por Dispersão de Energia de Raios-X (EDS).

A irradiação da amostra com elétrons provoca a emissão de elétrons secundários, elétrons retroespalhados e de Raios X, entre outros.

O microscópio eletrônico de varredura (MEV) é geralmente utilizado para o estudo de estruturas superficiais ou subsuperficiais de amostras com dimensões relativamente grandes, a partir de detectores de elétrons secundários e retroespalhados. As imagens têm alta profundidade de foco, o que significa obter diferentes relevos da superfície da amostra 
simultaneamente em foco. Imagens tridimensionais são formadas e, portanto, mais fáceis de interpretar que as imagens de projeção de microscopia de transmissão. A preparação de amostras e a obtenção de imagens são relativamente simples. A combinação destas características justifica o fato do microscópio eletrônico de varredura ser hoje um dos equipamentos mais utilizados na pesquisa de materiais.

A coluna do microscópio consiste de uma fonte de elétrons, lentes eletromagnéticas e bobinas de varredura, operando sob vácuo. A fonte de elétrons, normalmente um tipo de filamento de tungstênio, produz elétrons que são acelerados a uma energia na faixa de 1 a 40 $\mathrm{KeV}$, com correntes entre $10^{-6}$ e $10^{-12}$ A. O diâmetro do feixe produzido diretamente pela fonte de elétrons convencional é muito grande para gerar uma imagem definida em alta ampliação. As lentes eletromagnéticas, em conjunto com os diagramas, são usadas para reduzir o diâmetro do feixe e focalizá-lo sobre a superfície para formar uma imagem definida. As bobinas de varredura têm a função de defletir o feixe e controlar sua varredura sobre a superfície da amostra (Gonçalves, 2003). A emissão resultante de elétrons secundários ou retroespalhados é captada por detectores. Assim, é gerada uma imagem topográfica análoga à que se obtém ao se observar uma superfície de uma amostra em ângulo reto, ao mesmo tempo em que a mesma está sendo iluminada por uma fonte de luz direcionada a $45^{\circ}$. Interessante observar que micrografias obtidas de elétrons secundários possuem maior resolução espacial comparado aos de elétrons retroespalhados (cobertura de maior área de uma amostra) porém, sem contraste de composição com a profundidade resultando em uma imagem tipicamente topográfica, enquanto as micrografias obtidas por elétrons retroespalhados possuem menor cobertura de área de uma amostra, mas permitem imagens com contraste de composição e de topografia fornecendo informações sobre as camadas mais profundas (Correa, 2003).

Por outro lado, os Raios-X também gerados na interação entre o feixe de elétrons e a matéria podem ser detectados para identificar qualitativamente os elementos presentes em 
uma determinada amostra, processo esse denominado Espectroscopia por Dispersão de Energia de Raios-X acoplado ao MEV (EDS/MEV). Essa técnica faz uso da emissão de raios $\mathrm{X}$ característicos de átomos da amostra. Selecionando-se o detector em uma energia particular de raios $\mathrm{X}$, a imagem obtida mostra a variação espacial da concentração do elemento na região da amostra que está sendo realizada.

\section{Caracterização mineralógica - Fases cristalinas e a difração de Raios X}

A determinação das fases cristalinas dos resíduos está relacionada com a disponibilidade e mobilidade dos metais presentes. O uso de difração de raios X indica como os metais encontram-se complexados (Van Vlack, 1986) e geralmente podem complementar a análise qualitativa de um material obtido via EDS/MEV. Andrade (2005) estudou a viabilidade do uso de resíduos de ETAs em indústria cerâmica e reporta que a difração de raios $\mathrm{X}$ pode ser usada para determinar a fase cristalina mais freqüentes no lodo e recomenda a fluorescência de raios X para a determinação da composição ou porcentagem de óxidos presentes.

A técnica de difração de raios $X$ utiliza o espelhamento coerente de radiação $X$, por estruturas organizadas (cristais), permitindo realizar estudos morfológicos em materiais, determinando sua estrutura cristalina e sua fração (percentual) cristalina. Quando estas ondas eletromagnéticas de alta frequência são selecionadas para alcançar um comprimento de onda menor que o espaçamento interpolar dos cristais, elas são difratadas de acordo com leis físicas muito exatas. Os ângulos de difração permitem descrever a estrutura dos cristais com alto grau de precisão e segurança. Assim, as técnicas de difração e fluorescência de raios X apresentam potencial de aplicação em materiais metálicos e orgânicos. 
Sólidos e líquidos podem apresentar-se estruturados, espacialmente organizados, sendo capazes de difratar um feixe de raios X. A esta regularidade estrutural denominamos cristais, comuns em substâncias ou produtos sólidos.

Cristais podem atingir dimensões macroscópicas, visíveis sem o auxílio de lentes, mas apresentam uma identidade básica, a qual caracteriza o mesmo: uma célula unitária, a menor subcomponente de uma estrutura (rede) cristalina (Van Vlack, 1986). A partir desse princípio é que se procede a identificação de estruturas cristalinas.

GUERRA (1978) ${ }^{4}$ apud Dias (2000) apresenta as características dos principais argilominerais potencialmente encontrados nos lodos de ETAs.

$\underline{\text { Caulinita }}$ - Silicato de alumínio hidratado, cuja fórmula é $\mathrm{Al}_{2} \mathrm{O}_{3} .2 \mathrm{SiO}_{2} .2 \mathrm{H}_{2} \mathrm{O}$. Quando puras, possuem baixa plasticidade e baixa resistência mecânica., e é um dos argilo-mineral mais comumente encontrados.

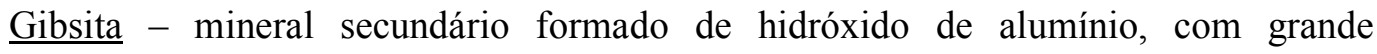
concentração de alumínio.

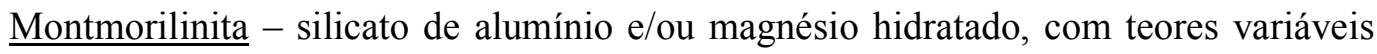
de óxidos de ferro, cálcio e magnésio. Potencialmente absorve água em quantidade considerável, o que o caracteriza pela elevada expansão e plasticidade.

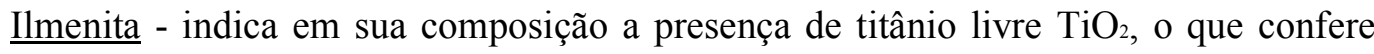
resistência mecânica.

Dessa forma, a informação quanto a composição mineralógica dos lodos de ETAs tem especial importância na avaliação de potenciais reaproveitamentos em cerâmicas, agregados de concreto entre outros (Oliveira, 2004).

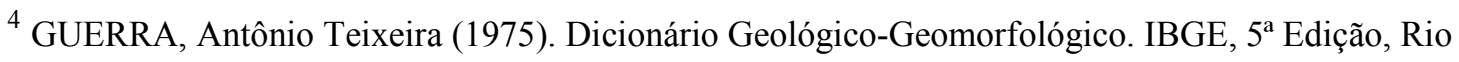
de Janeiro.
} 


\section{Densidade}

A densidade do floco é a relação entre a massa do floco (lodo) e massa de igual volume de água, e varia com o tamanho do floco. Quando a densidade decresce o tamanho do floco aumenta. Geralmente, os resíduos de ETAs apresentam valores de densidades entre 1,03 e $1,19\left(\mathrm{~g} / \mathrm{cm}^{3}\right)$ (ASCE e AWWA, 1996). Knocke e Wakeland (1983) demonstraram que o peso específico ou a densidade aparente podem ser determinantes à concentração de sólidos, obtido após desaguamento, conforme pode se observar na Tabela 4.5. Os autores citam ainda que o uso de polímeros como condicionantes não interferem significativamente na densidade do floco.

Tabela 4.5 - Densidade do floco e características de filtração de resíduos de várias ETA's.

\begin{tabular}{l|c|c|c}
\hline \multirow{2}{*}{\multicolumn{1}{c|}{ Tipo de lodo }} & \multicolumn{2}{|c}{ Densidade da partícula } & \multirow{2}{*}{$\begin{array}{c}\text { Teor de sólidos de torta } \\
(\%)\end{array}$} \\
\cline { 2 - 3 } & $\begin{array}{c}\text { Valor médio } \\
\left(\mathrm{g} / \mathrm{cm}^{3}\right)\end{array}$ & $\begin{array}{c}\text { Faixa de variação } \\
\left(\mathrm{g} / \mathrm{cm}^{3}\right)\end{array}$ & $7-9$ \\
\hline Alúmen (baixa densidade) & 1,005 & $1,002-1,008$ & $20-34$ \\
\hline Alúmen (alta densidade) & 1,013 & $1,008-1,018$ & 8 \\
\hline $\begin{array}{l}\text { Lodo condicionado com } \\
\text { alúmen }\end{array}$ & 1,002 & - & \\
\hline
\end{tabular}

Fonte: adaptado de Knocke e Wakeland (1983).

A densidade dos resíduos pode ser determinada pela Equação 4.1 sendo uma função inversa do teor de umidade do resíduo, válido segundo ASCE e AWWA (1996) para concentrações de sólidos totais menores que 50\% (em massa).

$$
\mathrm{D}=100 /\left[\left(\mathrm{ST} \% / \mathrm{D}_{\text {sólidos }}\right)+((100-\mathrm{ST} \%) / \text { Dágua })\right]
$$

Em que:

$\mathrm{D}_{\text {residuo }}=$ densidade úmida do resíduo em $\mathrm{kg} / \mathrm{m}^{3}$;

$D_{\text {sólidos }}=$ densidade dos sólidos determinada experimentalmente ou adotada igual a $2500 \mathrm{~kg} / \mathrm{m}^{3}$

$\mathrm{D}_{\text {água }}=$ densidade da água igual a $1000 \mathrm{~kg} / \mathrm{m}^{3}$.

\section{Concentração de sólidos}

A concentração de sólidos é de grande importância na avaliação de alternativas de tratamento e disposição dos resíduos de ETAs. Valores reportados na literatura mostram que 
os resíduos de decantadores apresentam concentração de sólidos entre 6.000 e 30.000 mg/L, enquanto que a água de lavagem dos filtros apresenta valores na faixa de $300 \mathrm{mg} / \mathrm{L}$ segundo Di Bernardo (2005). A variação dos valores de concentrações de sólidos depende de inúmeros fatores, tais como:

- Características da água bruta e adequação de tecnologia adotada;

- tipo e dosagem de produtos químicos utilizados,

- concepção da ETA, tipo de decantadores e filtros e respectivos mecanismos de limpeza.

- eficiência dos processos e operações envolvidos,

- duração e intervalo de lavagens dos decantadores e filtros

- Problemas operacionais e deficiência de recursos humanos.

Um dos fatores citados, mais importantes, a serem observados é o tipo de decantador adotado e a forma de descarte do lodo. Os lodos de decantadores convencionais com limpeza manual são descartados em grandes intervalos de tempo e apresentam-se mais concentrados, com grande volume de manuseio "pontual", mas em menor volume total que os originários de decantadores de alta taxa. O prolongado tempo de acumulação (dois a três meses) pode favorecer o desenvolvimento de condições anaeróbias com possível ressolubilização dos metais presentes no fundo dos decantadores, conforme pode ser observado em Souza (2004) e Barroso (2002). Já quando do uso de removedores mecânicos em decantadores convencionais obtém-se concentrações de sólidos intermediários de até 1\%.

\section{Viscosidade}

Gates e McDermott (1968) citam que o lodo de ETA, a partir de uma determinada concentração, é um fluido não-Newtoniano, e sendo assim, sua viscosidade é referida como “viscosidade aparente", pois varia com a concentração de sólidos. 
O conhecimento da viscosidade fornece subsídios para avaliação de perdas de cargas em tubulações (Slatter, 2001) e assume importância fundamental nos estudos reológicos a serem apresentados posteriormente. Dessa forma, pode auxiliar na definição das possibilidades de coleta, transporte e bombeamento do resíduo a ser tratado (ASCE e AWWA, 1996).

\section{Frações de água}

A partir do não congelamento da água de ligação (água não livre) a temperaturas abaixo do ponto de congelamento da água livre, estima-se a água total na amostra por evaporação (análise de sólidos secos) e então se mede o volume de água congelável, a $-20^{\circ} \mathrm{C}$ por dilatometria. Assim, o volume da água de ligação é obtida pela diferença entre a água total e o volume de água congelável. Vale ressaltar que a água de ligação é constituída pelas frações de água vicinal e de hidratação. Sua estimativa fornece indiretamente o limite de desaguamento mecânico (Vesilind e Hsu, 1997).

\subsubsection{Macropropriedades dos resíduos de ETAs}

\section{Velocidade de Sedimentação ou Sedimentabilidade}

No estudo de velocidade de sedimentação ou sedimentabilidade de suspensões como no caso de lodos de ETAs, são definidos em geral três tipos de sedimentação determinados em função da natureza dos sólidos suspensos ou características da suspensão e concentração de sólidos suspensos: A sedimentação discreta, floculenta e sazonal.

A sedimentação discreta ocorre normalmente em lodos com baixo valor de concentração de sólidos ou baixa viscosidade.

A sedimentação floculenta e/ou sazonal ocorre porque as partículas sólidas em suspensão possuem concentrações muito elevadas e propriedades físicas e químicas semelhantes, como no caso de lodos de ETAs. 
A interpretação e explicação deste tipo de sedimentação, sob a ótica dos lodos de ETAs, pode auxiliar na compreensão da sedimentação no processo de desaguamento por sistemas naturais, mais particularmente por Leito de drenagen.

Algumas considerações a respeito dos ensaios de sedimentação serão relatadas adiante, com base nos estudos de sedimentação reportados por Jordão e Pessoa (2005); Santos, Barbosa Filho e Giordano (2005).

A Figura 6.44, reportada e adaptada de Santos, Barbosa Filho e Giordano (2005), ilustra a evolução da sedimentação do tipo sazonal que pode ocorrer com diversos tipos de suspensões e particularmente com amostras de lodos de ETAs. Nesse contexto são feitas algumas considerações.

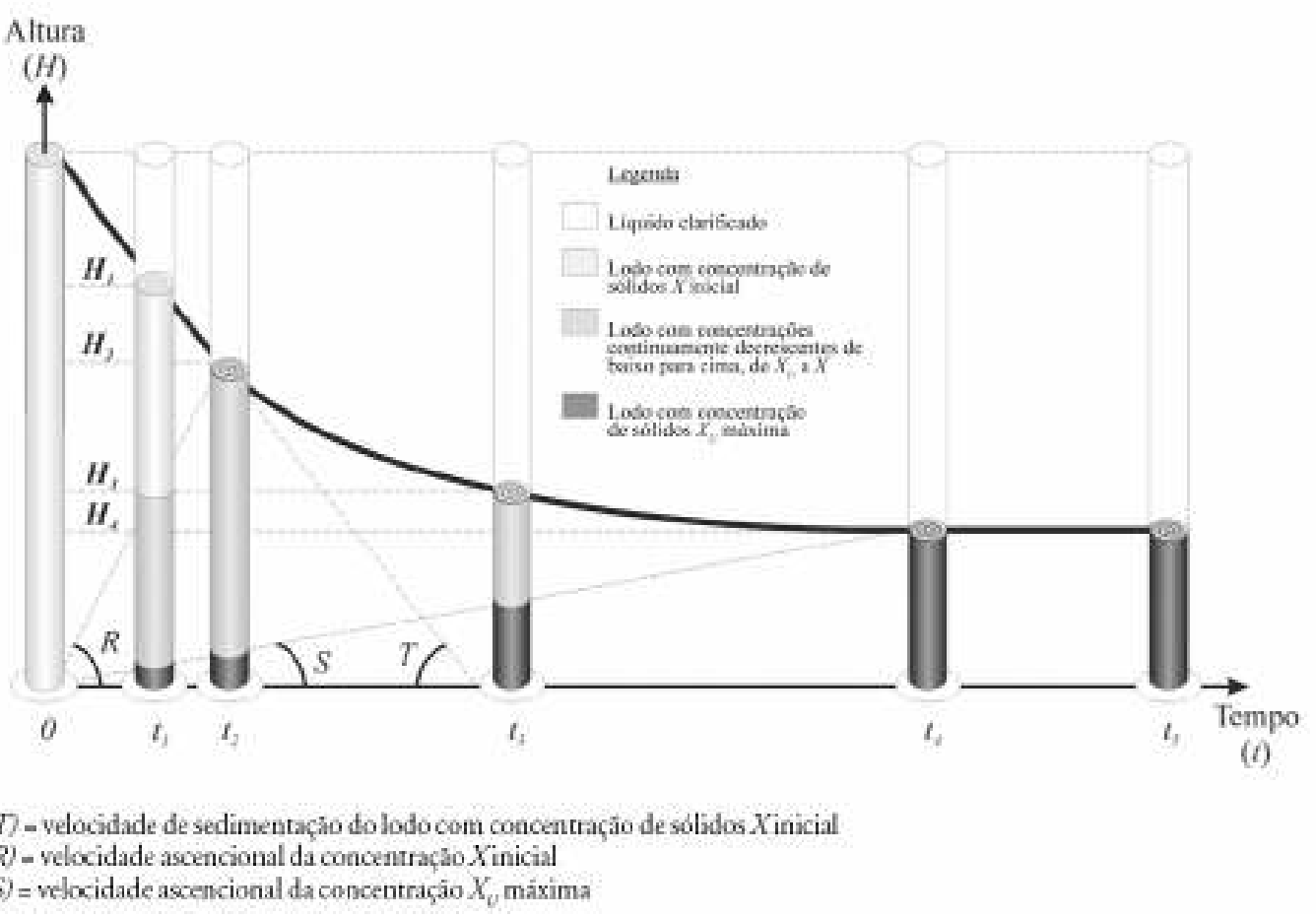

Figura 4.4 - Ilustração esquemática de curva de sedimentação do tipo sazonal.

Fonte: Adaptado de Santos, Barbosa Filho e Giordano (2005). 
No instante inicial $\mathrm{T}_{\mathrm{o}}$ (Figura 4.4), o lodo está presente em toda altura H. À medida que o lodo sedimenta, aumenta a concentração de sólidos nas camadas inferiores e conseguinte redução da velocidade de sedimentação até tornar-se nula, e ao mesmo tempo atinge a concentração máxima de sólidos.

A descrição pormenorizada pode ser enunciada como se segue. Em síntese, decorrido $d t$ após o início da sedimentação, forma-se junto ao fundo uma infinidade de camadas, com espessuras infinitesimais (cujo somatório é também infinitesimal). As concentrações de sólidos apresentam, de baixo para cima, uma variação contínua e decrescente, desde $X u$ (concentração máxima) até $X$.

Enquanto a sedimentação evolui, a interface líquido clarificado-lodo, que é um plano horizontal onde a concentração de sólidos é $X$, descende à velocidade constante $V s$. Ao mesmo tempo, a contínua transferência de sólidos para o fundo faz com que tenha sua concentração aumentada cada uma das infinitas camadas que apresentam, de baixo para cima, concentrações de sólidos que variam da máxima $X u$ à inicial $X$.

Como a concentração não pode crescer além de $X u$, dá-se o aumento da espessura da camada mais de baixo, à medida que, ordenadamente de baixo para cima, nas demais infinitas camadas é atingida $X u$. Assim, a superfície superior da camada com concentração de sólidos máxima ascende.

Santos et. al. (2005) cita que normalmente a taxa de transferência de sólidos descendentes é invariável, e ascende a uma velocidade constante $V a u$, característica de $X u$. Uma vez que cada uma das outras infinitas camadas também têm sua concentração aumentada continuamente, cada concentração, a exemplo da máxima, ascende à velocidade constante própria.

Decorrido um tempo $t_{1}$ do início da sedimentação, a interface líquido clarificado-lodo sedimenta à velocidade $V s$, atingindo a distância $V_{s} t_{l}$ da superfície do líquido. 
Simultaneamente, do fundo se eleva a concentração $X u$, à velocidade $V a u$, alcançando uma altura $\mathrm{Vau} \cdot t_{1}$ medida do fundo. Também ao longo de $\mathrm{t}_{1}$, cada camada com concentração entre $X u-d X$ e $X$ ascende com sua velocidade característica. A camada com concentração $X$ terá então se erguido à sua velocidade ascensional $V_{A X}$, passando a situar-se $V_{A X} \cdot t_{1}$ acima do fundo do cilindro.

Do início do processo até um tempo $t_{2}$, a interface líquido clarificado-lodo sedimenta à velocidade constante $V s$, a máxima ao longo de todo o processo, posto que nela a concentração de sólidos é $X$, constante e mínima. A curva Altura da Coluna de Lodo X Tempo, neste intervalo, é um segmento de reta, conforme pode ser observados na Figura 4.6.

A partir de $t_{2}$, tendo continuidade a sedimentação, a cada intervalo infinitesimal de tempo $d t$ transcorrido, a concentração de sólidos da interface líquido clarificado-lodo é substituída por uma concentração infinitesimalmente maior ascendente que alcança o topo da coluna de lodo. A cada aumento de concentração corresponde uma redução na velocidade de sedimentação da interface para o valor característico da nova concentração. Assim, a partir de $t_{2}$, a velocidade de sedimentação da interface diminui ininterruptamente até um instante $t_{4}$. Em $t_{4}$ a concentração de sólidos máxima $X_{U}$ atinge a interface e a velocidade de sedimentação desta se torna nula, completando-se o processo da sedimentação.

Assim sendo, no intervalo limitado por $t 2$ e $t 4$, a curva Altura da Coluna de Lodo X Tempo deixa de ser retilínea, adquirindo uma curvatura que cresce de zero até um valor máximo e depois diminui de volta para zero. O trecho final da curva Altura da Coluna de Lodo X Tempo é uma semi-reta horizontal, pois a velocidade de sedimentação é nula e a altura de lodo permanece constante.

Os mecanismos supracitados podem ser observados durante a realização de ensaios em coluna de sedimentação. Contudo, para o caso particular dos leitos de drenagens, ocorre a retirada ou drenagem de água a partir das camadas de fundo, concomitante à sedimentação. 


\section{Resistência Específica}

A resistência específica pode ser definida como, a resistência oferecida por um peso unitário de lodo à passagem de água, e pode ser determinada por meio da Equação 4.2. Quanto maior a resistência específica, menor a capacidade de filtração da água (Cordeiro, 1993).

$$
r=\frac{2 \times b \times P \times A^{2}}{\mu \times C}
$$

Em que:

$\mathrm{r}=$ resistência específica $(\mathrm{cm} / \mathrm{g})$;

$\mathrm{P}=$ pressão de filtração $\left(\mathrm{g} / \mathrm{cm} \mathrm{x} \mathrm{seg}^{2}\right)$;

$\mathrm{A}=$ área filtrante $\left(\mathrm{cm}^{2}\right)$

$\mu=$ viscosidade do filtrado ( $\mathrm{g} / \mathrm{cm} \times \mathrm{seg})$;

$\mathrm{C}=$ massa de sólidos suspensos por unidade de volume filtrado $\left(\mathrm{g} / \mathrm{cm}^{2}\right)$;

$\mathrm{b}=$ coeficiente $\left(\mathrm{s} / \mathrm{cm}^{6}\right)$, dado pela relação $\mathrm{t} / \mathrm{v} \mathrm{X}$ v.;

$\mathrm{t}=$ tempo de filtração (s);

$\mathrm{v}=$ volume filtrado $\left(\mathrm{cm}^{3}\right)$.

A resistência específica tem sido muito usada para avaliar e otimizar o desempenho de sistemas de desaguamento de resíduos, ou seja, definir a taxa de desaguamento e auxiliar a escolha e dosagem de condicionantes químicos. Salienta-se que o uso desse parâmetro tem importância somente para sistemas mecânicos de desaguamento.

\section{Compressibilidade}

A característica de deformação do floco durante o desaguamento pela aplicação de pressão é definida como compressão. A principal consequência da compressão (deformação dos flocos) é o decréscimo da taxa de desaguamento com o aumento da pressão aplicada. A maior parte dos resíduos, originários da coagulação, são altamente compressíveis (ASCE e AWWA, 1996). Segundo Knocke \& Wakeland (1983), as mudanças no tamanho das partículas não afetam a compressibilidade do lodo. O coeficiente de compressibilidade, S, normalmente é determinado graficamente mediante ensaio que relacione resistência específica e pressão aplicada. 


\subsubsection{Considerações Sobre as Micro e Macropropriedades e Características Reológicas dos Resíduos de ETAs}

Ao realizar a análise crítica sobre as micro e macropropriedades supracitadas e suas relações com a escolha de tecnologias de manejo e tratamento dos lodos, percebe-se o caráter predominantemente empírico. Caracterizações e ensaios realizados em escala de laboratório com objetivo de "prever" o comportamento lodo e desempenho das tecnologias adotadas em escala real pode inferir discrepâncias de resultados, muitas vezes incomparáveis entre distintos processos e entre diferentes resíduos (Dentel, 1997). Esse aspecto limita a compreensão da relação efetiva das micropropriedades com o desempenho do desaguamento. Nesse sentido pesquisadores apontam o uso da reologia para suprir tal deficiência.

O estudo das características reológicas de resíduos gerados em estações de tratamento de água e de esgoto tem se destacado, como nos estudos de Slatter (1997), Braga e Gonçalves (2000), Miki (1998), Dentel (1997). Esses estudos têm mostrado que as propriedades reológicas podem ser de grande validade para o projeto de sistemas de manejo, bombeamento e tubulações, e assume implicações nos processos de mistura, nas transferências de massa e no condicionamento com polímeros, e como conseqüência, no desempenho de sistemas naturais e mecânicos de desaguamento. Contudo, os estudos são incipientes e com maior enfoque na avaliação do manejo e transporte de resíduos.

A reologia pode ser compreendida como a ciência que estuda o escoamento e deformação da matéria, ou seja, descreve a deformação de um corpo sob a influência de tensões e remonta a postulações de Isaac Newton. Possui como princípio básico a relação entre tensão de cisalhamento e taxa de cisalhamento (Slatter, 1997). No caso de fluidos, como os resíduos de ETAs, esta relação pode ser estudada a partir de duas definições: fluidos Newtonianos e fluidos não-newtonianos. 
Os fluidos newtonianos são aqueles em que a tensão cisalhante tem relação direta e linear com o gradiente de velocidade ou taxa de cisalhamento, descrita pela Lei de Newton e expressa de acordo com a Equação 4.3 (Dentel, 1997).

$$
\begin{aligned}
& \tau=-\mu .(\mathrm{dv} / \mathrm{dy}) \\
& \text { Em que: } \quad \mu=\text { viscosidade. } \\
& (d v / d y)=\text { gradiente de velocidade ou taxa de cisalhamento; } \\
& \tau=\text { tensão de cisalhamento. }
\end{aligned}
$$

Nos fluidos newtonianos a viscosidade é considerada constante e é função da temperatura e concentração de sólidos. Para suspensões relativamente diluídas a relação entre a concentração de sólidos e viscosidade pode ser quantificada pela equação de Einstein, expressa na Equação 4.4 .

$$
\eta=\eta_{\mathrm{o}}\left[1+\varnothing / 2 /(1-\varnothing)^{2}\right]=\eta_{\mathrm{o}}(1+2,5 \varnothing)
$$

Em que: $\quad \eta, \eta_{\mathrm{o}}=$ viscosidade da suspensão e solvente.

$\varnothing=$ fração volumétrica ocupada por partículas.

A Equação 4.4 de Einstein é fundamental para obter relação entre a viscosidade de um lodo e suas características de desaguamento. Um aumento no valor de $\varnothing$ e, portanto, de $\eta$, pode ser relacionado ao aumento da concentração de sólidos ou pela incorporação de água no interior das partículas ou flocos. A partir dessas observações realizadas por Dentel (1997), pode-se esperar também relação entre as características reológicas de determinado lodo e as frações de água constituintes.

Os resíduos de ETAs, em função da concentração, geralmente são classificados como fluidos não-newtonianos, ou seja, não obedecem a proporcionalidade direta entre a tensão cisalhante e a taxa de cisalhamento ou deformação dv/dy, (Miki, 1998). Assim, o coeficiente de viscosidade é variável com a "taxa" de cisalhamento e nesse caso, o coeficiente de viscosidade é definido como viscosidade aparente. Para a descrição do comportamento de fluidos não-newtonianos, encontra-se na literatura os mais variados modelos: Slatter (1997) cita a adoção de fluido pseudoplástico e fluido de Binghan; Dentel (1997) apresenta a 
descrição de fluidos não-newtonianos a partir de três equacionamentos: Ostwald (Equação 4.5); Binghan (Equação 4.6); e Herschel-Bulkley (Equação 4.7), obtidos a partir de Spinoza et al. (1989) e Dick (1979). Além disso, Dentel (1997) discute os fatores intervenientes na adoção destes modelos, os quais são aqui sumariamente apresentados:

$$
\begin{array}{ll}
\text { Equação Ostwald: } & \tau=-\eta_{\mathrm{p}} \cdot(d v / d y)^{\mathrm{n}} \\
\text { Equação Binghan: } & \tau=-\tau_{\mathrm{o}}+\eta_{\mathrm{p} \cdot} \cdot(d v / d y) \\
\text { Equação Herschel-Bulkley } & \tau=-\tau_{\mathrm{o}}+\eta_{\mathrm{p} \cdot} \cdot(d v / d y)^{\mathrm{n}}
\end{array}
$$

Em que: $\quad \tau=$ tensão de cisalhamento.

$\eta_{\mathrm{p}}=$ viscosidade plástica;

$\tau_{\mathrm{o}}=$ campo de tensão inicial;

$(d v / d y)=$ gradiente de velocidade ou taxa de cisalhamento.

O termo $\tau_{\mathrm{o}}$ (campo de tensão inicial) nos modelos de Binghan e Herschel-Bulkley é devido à resistência à deformação do lodo até que a força aplicada exceda o campo limite de resistência da fase sólida, normalmente relacionado a lodos com elevado teor de sólidos.

Dentel (1997) reporta que, na prática, qualquer tentativa de medição em fluidos não newtonianos "impõe" uma taxa de cisalhamento e afeta o resultado da medição da tensão de cisalhamento. Mesmo assim, a taxa de cisalhamento pode ser determinada indiretamente, a partir de velocidades conhecidas e relacionada com pressão, força ou torque.

Outro aspecto que interfere, no caso de lodo de ETAs, é a ocorrência de quebra ou destruição das estruturas floculentas que ditam o comportamento desses fluidos, além da possibilidade de sedimentação de partículas. Adiciona-se a isso, a natureza tixotrópica da maioria dos lodos, ou seja, as características reológicas são variáveis com o tempo, devido à tendência floculante dessas suspensões e possíveis reações químicas diversas. Dessa forma, Dentel (1997) cita o uso de viscosímetros rotacionais, como o mais apropriado para o estudo da reologia de lodos. 
O empacotamento de partículas é outra propriedade importante do ponto de vista reológico e tem relação com a fração volumétrica de partículas e mais precisamente com a distribuição de tamanho de partículas. Seu conhecimento tem sido utilizado nos mais diversos tipos de processos industriais e pesquisas correlatas. O princípio consiste em existir distribuições de tamanho de partículas que favorecem a obtenção de compactos densos e estruturas com menor tamanho de poros. Além disso, a distribuição granulométrica afeta diretamente o comportamento reológico de suspensões, e quando adequada, permite conciliar alto teor de sólidos com baixa viscosidade (Ortega et al., 1997).

Estas características apresentam-se de suma importância no desaguamento de lodos de ETAs pois podem ser traçados paralelos. Segundo Ortega et al. (1997), em linhas gerais, um empacotamento denso de partículas consiste em uma estrutura de partículas grandes cujos interstícios são preenchidos por partículas menores, criando novos interstícios que serão preenchidos por partículas ainda menores, e assim sucessivamente. Este empacotamento é diretamente influenciado por alguns fatores, como a distribuição de tamanhos, o formato e a rugosidade superficial das partículas. Assim, a descrição do fenômeno de empacotamento pode ser usada para compreender e prever os mecanismos de sedimentação e adensamento de lodos.

Encontram-se na literatura diversos modelos matemáticos que estudam a obtenção de uma curva de distribuição de tamanho de partículas com o intuito de maximizar a densidade de empacotamento dos compactos. Dentre estes, os modelos de Alfred e Andreasen estão entre os mais conhecidos. Esses modelos são baseados em uma condição de similaridade entre partículas grandes e partículas menores distribuídas ao seu redor, a qual pôde ser relacionada a uma série de potências resultando nas seguintes equações:

Para o caso do modelo de Alfred, descreve-se a Equação 4.8

$$
\frac{\mathrm{CPFT}}{100}=\left(\frac{\mathrm{D}}{\mathrm{D}_{\mathrm{L}}}\right)^{\mathrm{q}}
$$


onde: $\mathrm{CPFT}=$ Porcentagem acumulada de partículas menores que o tamanho D;

$\mathrm{D}=$ diâmetro da partícula;

$\mathrm{D}_{\mathrm{L}}=$ Tamanho da maior partícula do sistema;

$\mathrm{q}=$ módulo de distribuição.

Para o caso do modelo de Andreasen, descreve-se a Equação 4.9.

$$
\frac{C P F T}{100}=\left(\frac{D^{q}-D_{s}^{q}}{D_{L}^{q}-D_{s}^{q}}\right)
$$

onde: $\mathrm{D}_{\mathrm{S}}$ é o diâmetro da menor partícula do sistema.

Nota-se que se o valor de $\mathrm{D}_{\mathrm{S}}$ for igual a zero, a equação se reduz ao modelo de Andreasen. A equação de Alfred é considerada atualmente o modelo de empacotamento de partículas mais adequado a sistemas reais (Ortega et al., 1997).

Simulações computacionais realizadas posteriormente mostraram que um valor de $\mathrm{q}=$ 0,37 proporciona a máxima densidade de empacotamento. Os modelos descritos têm sido utilizados com relativo sucesso no processamento cerâmico.

Para o caso de lodos de ETAs, mostra-se interessante o uso de tais modelos baseados no modulo de distribuição q, como forma de conhecer ou até induzir a formação de massas de lodo mais compactas (desaguamento mais eficiente). Contudo, mais uma vez é necessário ressalvas e mais estudos a respeito, haja visto as demais propriedades do lodo, seja a questão de predomínio de partículas floculentas, seja relacionadas com as características químicas.

\subsection{Sistemas de Desaguamento de Resíduos de ETAs}

O tratamento ou redução de volume de resíduos de ETAs pode ser realizado basicamente, a partir do uso sistemas naturais e/ou sistemas mecânicos de remoção de água, compreendendo os diversos métodos e etapas apresentados na Figura 4.5.

O Brasil, muitas vezes, reune condições favoráveis de espaço e recursos naturais, seja matéria prima, insumos e abundância de energia proveniente do sol (biomassa, energia solar, etc.), ao contrário da maioria dos paises desenvolvidos que historicamente conduziram o 
desenvolvimento de tecnologias de tratamento de água e de resíduos. Estas condições, quando aliadas ao baixo custo de instalação e operação, indicam potencial vantagem na adoção de sistemas naturais para o tratamento de resíduos de ETAs. Dessa forma, será destacado o desaguamento por sistemas naturais que envolvem, de maneira geral, as lagoas de lodo e leito de secagem, incluindo particularmente leito de drenagem.

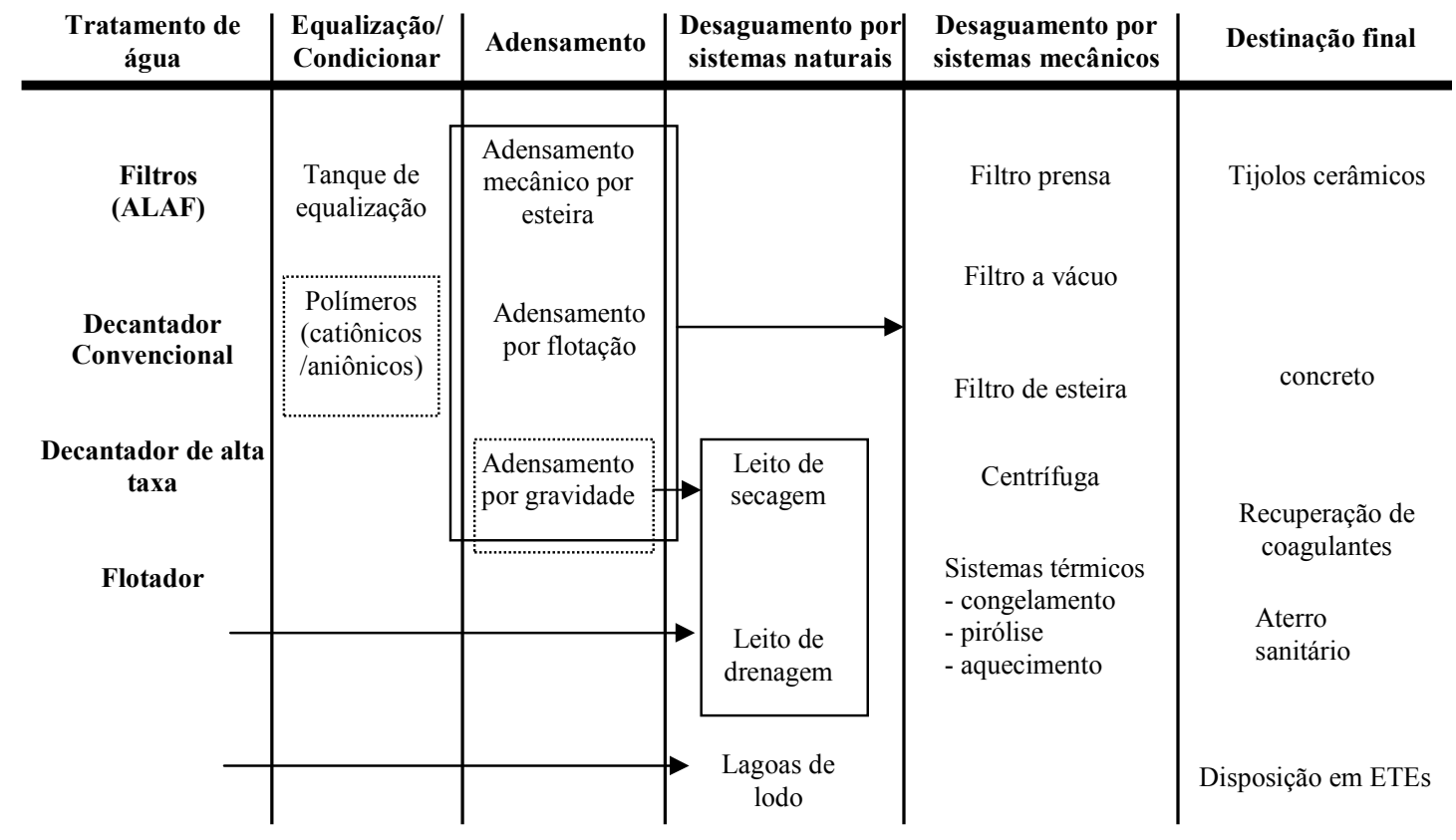

Figura 4.5 - Ilustração esquemática das diversas etapas e métodos de tratamento de resíduos gerados em ETAs.

No que tange às pesquisas desenvolvidas, pode-se dizer que existem dados referentes a processos de remoção de água por sistemas naturais, tais como: leitos de secagem modificados e lagoas de lodo que permitem discutir essas soluções com mais efetividade. Os problemas enfrentados pelos sistemas das cidades de Rio Claro e São Paulo, no estado de São Paulo, são exemplos discutidos a seguir.

Em 1991 entrou em operação a ETA Taioçupeba, situada na região do Alto Rio Tietê com vazão final de projeto de $15 \mathrm{~m}^{3} / \mathrm{s}$ na RMSP, gerenciada pela SABESP. Nesse sistema foram projetados: tanques de recuperação de água de lavagem de filtros; lagoas de lodo para 
remoção de água do lodo dos decantadores e do lodo resultante dos tanques de recuperação de água de lavagem de filtros. Esse sistema se mostrou totalmente ineficiente, pois não era possível remover a água do lodo de forma adequada. O problema nesse caso foi a concepção do projeto. O mesmo não levou em conta o clima e a geologia da região. A ETA situa-se em região de alta umidade que não permite a evaporação adequada da água livre presente no lodo. Além disso, a distribuição de tamanho das partículas foi potencialmente decisiva na "impermeabilização" do fundo das lagoas, impedindo a percolação da água para o solo - vale salientar que esta prática, de prever infiltração no solo/fundo de lagoa, vem sendo combatida.

A utilização de lagoas de lodo também não se mostrou efetiva na ETA de Rio Claro SP. Nessa estação foram projetadas e construídas lagoas cujo fundo era impermeável. O lodo disposto nessas lagoas é deixado em repouso, proporcionando a sedimentação das partículas e o sobrenadante é removido através de tubulações que funcionam como vertedores. O grande problema desse sistema diz respeito ao projeto e à operação, principalmente relativo à remoção do sobrenadante e formação de uma camada de água intermediária entre o fundo impermeável e camada de lodo seco, quando da infiltração de água pluvial, conforme se observa na Figura 4.6.

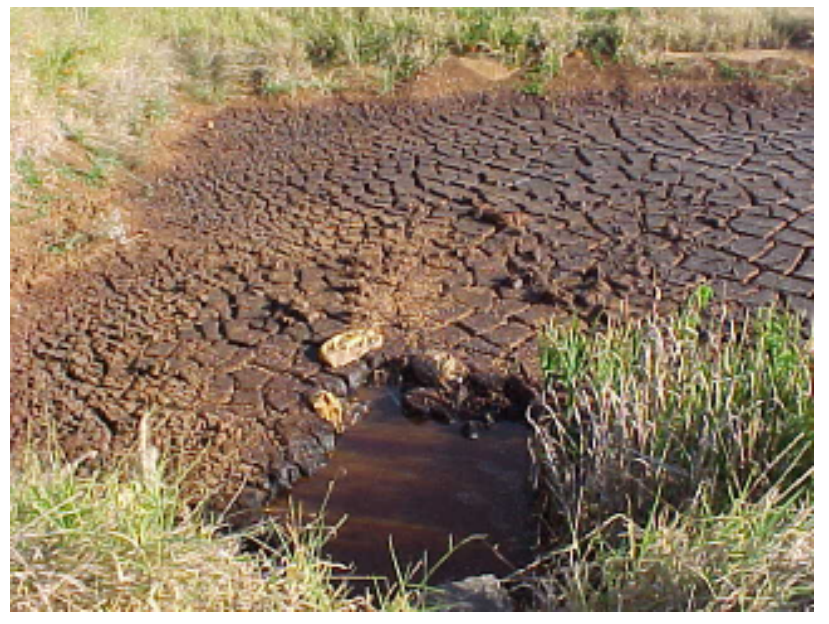

Figura 4.6 - Camada de água sob lodo seco em lagoas de lodo.

Fonte: Achon e Cordeiro (2003). 
Na ETA Rio Descoberto e ETA Pipiripau, situadas em Brasília - DF, os sistemas foram projetados como filtração direta, e nessas, as águas de lavagem dos filtros são encaminhadas ao adensamento por gravidade e posteriormente para centrífugas, que fazem a remoção da água livre. Essa água volta para o adensador e os sólidos são descartados em aterros. No entanto, segundo os responsáveis, esse descarte de sólidos está sendo considerado como temporário pelos órgãos ambientais. Deve-se enfatizar que os adensadores consomem energia e produtos químicos, além de apresentar problemas operacionais e de manutenção. É necessário ainda computar o custo das centrífugas empregadas nesses sistemas.

No caso de Cubatão - SP, os órgãos de meio ambiente exigiram soluções para o problema dos resíduos da ETA, que trata cerca de $4 \mathrm{~m}^{3} / \mathrm{s}$. Nesse caso, foram projetados sistemas de filtros prensa de esteiras.

Apesar das várias experiências com sistemas mecânicos, o uso de sistemas naturais também tem sido usado com êxito, a exemplo dos casos de Cardoso e Guaíra (São Paulo), Campo Grande (Mato Grosso do Sul) e outros.

Os sistemas atualmente existentes no Brasil ainda possuem problemas a serem solucionados, seja na questão operacional, seja no descarte dos sólidos após a remoção de água. No caso das lagoas, a possibilidade de sua utilização deve ficar restrita às regiões de alta insolação e com solo permeável, desde que os lençóis subterrâneos sejam monitorados para evitar a possibilidade de poluição.

Os sistemas de leitos de drenagem (leitos de secagem modificados) têm mostrado alto desempenho em protótipos desenvolvidos e aplicados nas ETAs de São Carlos e Rio Claro SP, e em sistemas reais, como é o caso de Cardoso e Guairá. Dessa forma, mostram-se alternativas promissoras, principalmente em locais onde as ETAs possuem áreas próximas disponíveis. Além disso, as águas excedentes ou de processo podem ser recuperadas. 


\subsubsection{Sistemas naturais de desaguamento - Leito de Drenagem}

A tecnologia dos leitos de secagem tem sido utilizada para remoção de água de rejeitos de diversos tipos de tratamento de águas residuárias e de abastecimento desde o início do século XX, e, a partir de então, vem sendo aplicada praticamente sem mudança considerável em sua estrutura física.

Dentre as evoluções ocorridas nesse sistema podem ser citadas: leito de secagem a vácuo; leitos de secagem de tela em cunha; tradicionais; e leitos pavimentados. Outros arranjos têm sido descritos, como os leitos solares, utilizados no sul e sudoeste dos EUA, em virtude das características climáticas favoráveis à evaporação de parte da água livre. Esses sistemas foram mostrados por Vandermeyden e Cornwell (1998).

Cordeiro (1993;2001), estudou a possibilidade de modificação dessa estrutura e observou que a colocação de manta de geotêxtil sobre a camada filtrante do leito possibilitava a remoção mais efetiva da água livre dos lodos, mesmo utilizando areias de construção (grossa e fina), adquiridas no mercado, como meio filtrante. Essa areia era lavada e os leitos testados com espessura de areia de 5 e $10 \mathrm{~cm}$. Os resultados obtidos evidenciaram que a areia e a espessura da camada filtrante não eram decisivos na remoção de água livre.

Os estudos evoluíram e no PROSAB 2 - Tema 4, Cordeiro (2001) desenvolveu a proposta de um leito modificado 2, onde a areia foi removida e o leito constituído de uma camada de brita $01 \mathrm{com} 5 \mathrm{~cm}$ e sobre ela manta geotêxtil, com a camada de lodo atingindo até $50 \mathrm{~cm}$. A Figura 4.7 ilustra a evolução dos sistemas de leitos de secagem, estudada por Cordeiro, desde o tradicional até o desenvolvido no PROSAB.

O tempo de drenagem da água livre diminuiu bruscamente com o novo arranjo (modificado 2), como mostra a Figura 4.8, que compara o Leito de secagem tradicional, o modificado por Cordeiro em 1993, nomeado como modificado 1, e remodelado em 2000, recebendo a denominação de modificado 2 . 


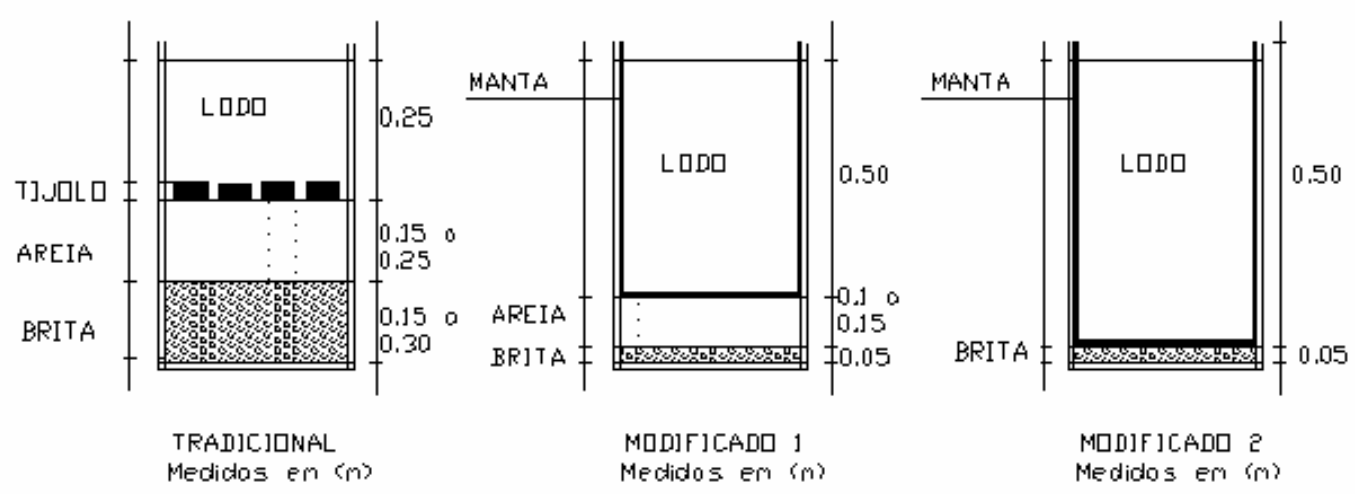

Figura 4.7 - Etapas de desenvolvimento dos sistemas de leitos de secagem Fonte: Cordeiro (2001)

A Figura 4.8, possibilita visualizar os resultados do volume filtrado, por tempo de drenagem, mostrando que o modificado 2, tem uma eficiência superior no que diz respeito ao volume filtrado para um determinado tempo de drenagem.

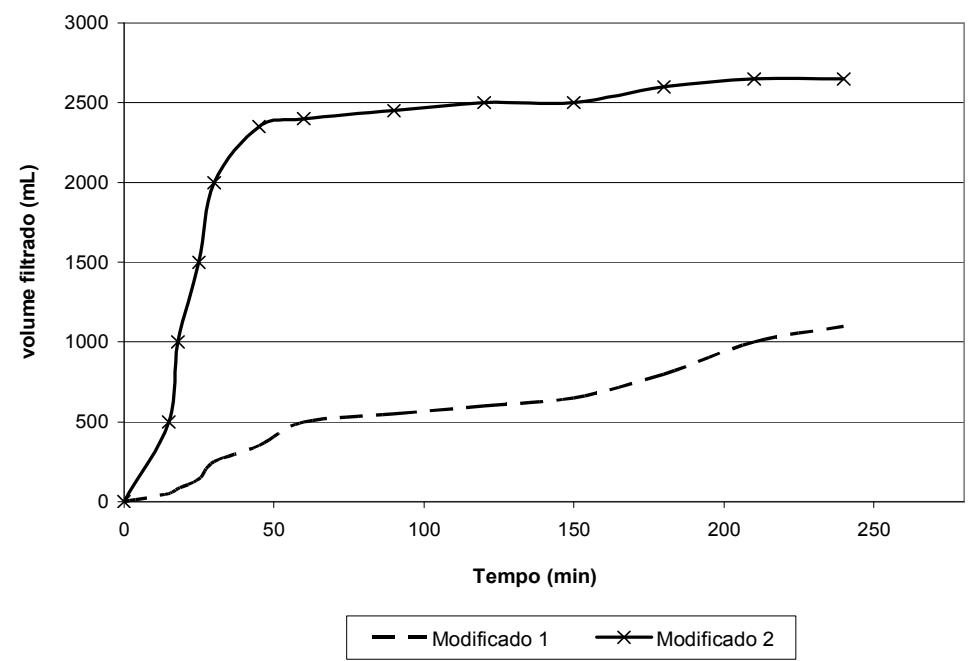

Figura 4.8 - Curvas de remoção de água filtrada de sistemas, modificado por Cordeiro 1993 e remodelado em 2000.

Fonte: Cordeiro (2001).

Nesse sentido, Achon e Cordeiro (2003) desenvolveram pesquisas, dentro do Programa de Pesquisa em Saneamento Básico - PROSAB, com uso de leitos de secagem modificados em Cordeiro (2001), para verificar a readaptação de lagoas de lodo que 
apresentavam inúmeros problemas. Os resultados obtidos demonstraram a diminuição do tempo de remoção da água livre e obtenção de drenado de boa qualidade, passível de reutilização ou recuperação. O leito de secagem modificado em Cordeiro (2001) recebeu a denominação de Leito de Drenagem.

Fontana (2004), no município de Cardoso-SP, construiu um leito de drenagem em escala real, com área de $60 \mathrm{~m}^{2}$ e altura de $0,50 \mathrm{~m}$, conforme pode ser observado em planta (Figura 4.9) e corte (Figura 4.10), precedido por um sedimentador. A manta geotêxtil usada é do tipo não tecida de poliéster, de referência comercial MT 600 da Maccaferri, com densidade superficial de $600 \mathrm{~g} / \mathrm{m}^{2}$, abertura de 0,06 a $0,13 \mu \mathrm{m}$ e espessura de $4,4 \mathrm{~mm}$.

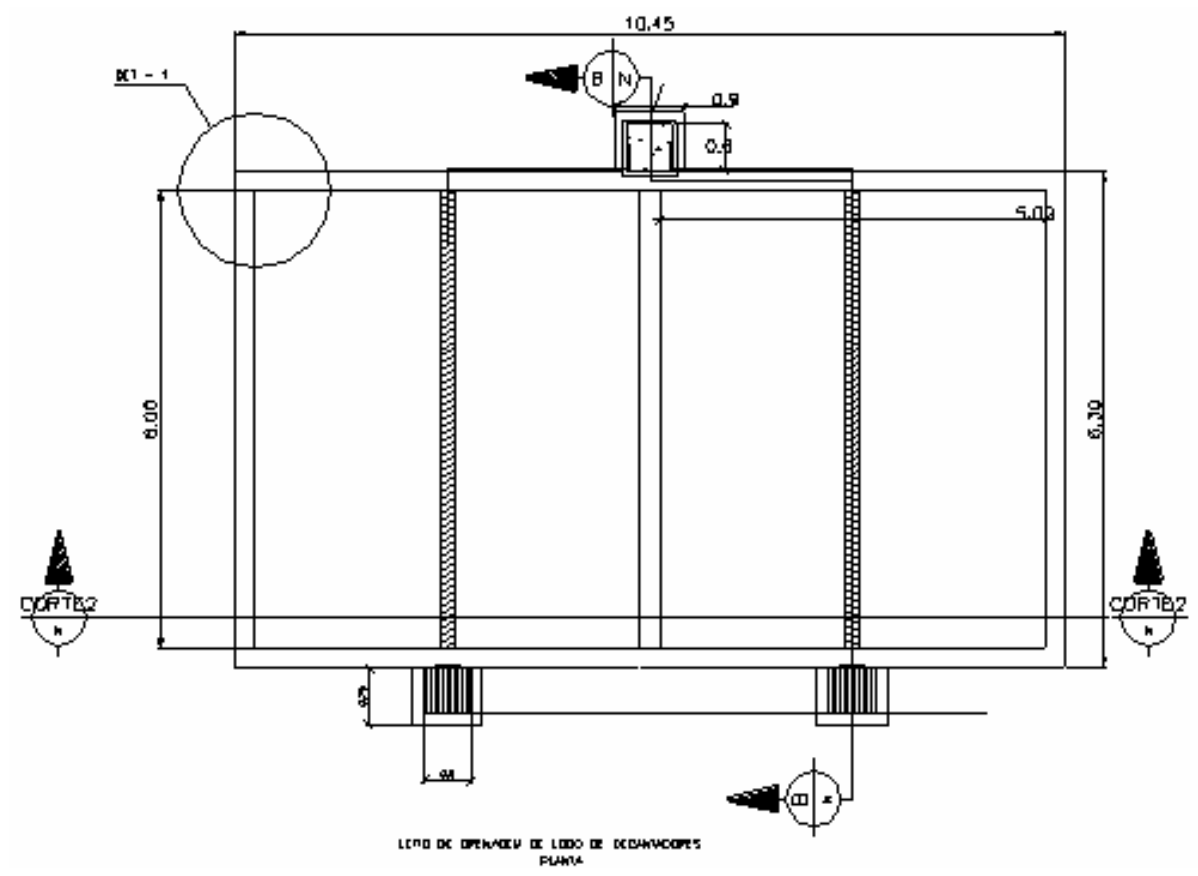

Figura 4.9 - Planta dos módulos do Leito de Drenagem.

Fonte: Fontana (2004)

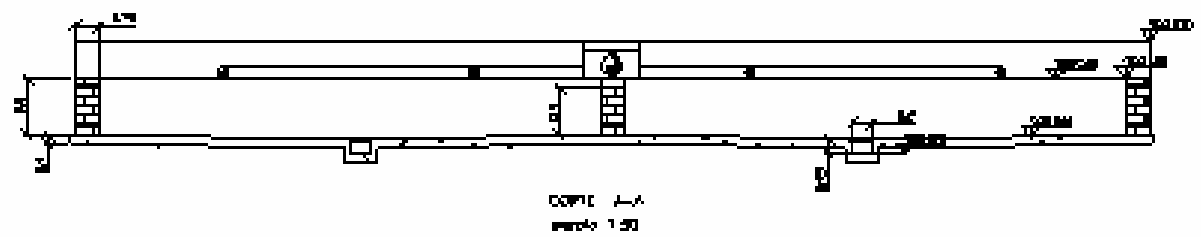

Figura 4.10 - Corte da estrutura do Leito de Drenagem.

Fonte: Fontana (2004) 
Os resultados obtidos demonstraram elevado desempenho no desaguamento com redução de $98 \%$ do volume de resíduos e qualidade do drenado quanto à turbidez, $\mathrm{pH}$, série de sólidos e DQO, conforme apresentados na Tabela 4.5.

Tabela 4.5 - Características do lodo de decantador e drenado do Leito de Drenagem de resíduos da ETA Cardoso.

\begin{tabular}{l|c|c|c|c}
\hline \multirow{2}{*}{ Parâmetros } & \multicolumn{2}{|c|}{ DECANTADOR } & \multicolumn{2}{c}{ DRENADO } \\
\cline { 2 - 5 } & $\mathbf{1 6 / 1 2 / 0 3}$ & $\mathbf{0 6 / 0 1 / 0 4}$ & $\mathbf{1 6 / 1 2 / 0 3}$ & $\mathbf{0 6 / 0 1 / 0 4}$ \\
\hline Turbidez (uT) & - & - & 0,7 & 0,9 \\
\hline $\mathrm{pH}$ & 6,6 & 7,0 & 6,6 & 6,8 \\
\hline Sólido sedimentável (mg/L) & 860 & 850 & 0,08 & 0,03 \\
\hline Sólido total (mg/L) & 98397 & 28263 & 261 & 285 \\
\hline Sólido fixo (mg/L) & 30368 & 20032 & 102 & 107 \\
\hline Sólido volátil (mg/L) & 68029 & 8231 & 159 & 178 \\
\hline Sólido suspenso total (mg/L) & 25150 & 28400 & 18 & 14 \\
\hline Sólido suspenso fixo (mg/L) & 1200 & 5350 & 5 & 4 \\
\hline Sólido suspenso volátil (mg/L) & 23950 & 23050 & 13 & 10 \\
\hline
\end{tabular}

(-) Não determinado

Fonte: adaptado de Fontana (2004).

Na Tabela 4.6, Fontana (2004) apresenta os valores de concentração de metais no lodo do decantador e na água livre drenada do protótipo do leito de drenagem. Pode-se verificar que o leito de drenagem foi efetivo para a remoção dos metais e em conformidade com a Resolução CONAMA 357.

Tabela 4.6 - Características do lodo de decantador da ETA Cardoso e do drenado resultante da aplicação no protótipo de Leito de Drenagem.

\begin{tabular}{l|c|c|c}
\hline Parâmetros & CONAMA 357 & $\begin{array}{c}\text { Lodo de Decantador } \\
\mathbf{0 6} / \mathbf{2 0 0 3}\end{array}$ & $\begin{array}{c}\text { Drenado do } \\
\text { Protótipo }\end{array}$ \\
\hline SST $(\mathrm{mg} / \mathrm{L})$ & 500 & 22200 & 176 \\
\hline DQO $(\mathrm{mg} / \mathrm{L})$ & - & 7500 & 26 \\
\hline Alumínio $(\mathrm{mg} / \mathrm{L})$ & 0,1 & 1700 & 0,13 \\
\hline Cádmio $(\mathrm{mg} / \mathrm{L})$ & 0,001 & 0,12 & 0,0081 \\
\hline Chumbo $(\mathrm{mg} / \mathrm{L})$ & 0,03 & 2,66 & 0,021 \\
\hline Cobre $(\mathrm{mg} / \mathrm{L})$ & 0,02 & 1,39 & 0,008 \\
\hline Cromo total $(\mathrm{mg} / \mathrm{L})$ & 0,05 & 2,7 & 0,005 \\
\hline Ferro total $(\mathrm{mg} / \mathrm{L})$ & 0,3 & 3014 & 0,77 \\
\hline Manganês $(\mathrm{mg} / \mathrm{L})$ & 0,1 & 101 & 23,7 \\
\hline Mercúrio $(\mathrm{mg} / \mathrm{L})$ & 0,0002 & 0,1 & $<0,001$ \\
\hline Zinco $(\mathrm{mg} / \mathrm{L})$ & 0,18 & 3,18 & 0,99 \\
\hline Fosfato total $(\mathrm{mg} / \mathrm{L})$ & 0,025 & 33,72 & 0,09 \\
\hline (-) & & &
\end{tabular}

(-) Não determinado

Fonte: adaptado de Fontana (2004). 
No trabalho desenvolvido por Fontana (2004) foi demonstrado o potencial uso do Leito de Drenagem para desaguamento de resíduos de ETAs. Porém, nessa pesquisa, não foi possível avaliar a influência das variáveis climáticas e nem a compreensão mais detalhada do comportamento dos resíduos de ETAs durante as fases de drenagem e de secagem.

\subsection{Fundamentação Teórica no Uso de Mantas Geotêxteis.}

O desaguamento por Leito de Drenagem tem como principio básico o uso de elemento filtrante, no caso mantas geotêxteis, para a remoção de água livre e uso dos fatores climáticos na fase de secagem.

De maneira geral, todo elemento de filtração deve atender dois requisitos básicos, manter a capacidade drenante eficiente (eficiência hidráulica) e proporcionar a retenção de partículas. Assim, o material dreno/filtrante constituído pelas mantas geotêxteis deve apresentar um coeficiente de permeabilidade elevado, para promover a capacidade drenante da água livre e uma distribuição de tamanho de poros que, seja capaz de reter partículas floculentas ou sólidas.

Os filtros sintéticos, também denominados geotêxteis, são mantas permeáveis, flexíveis e finas produzidas a partir de fibras sintéticas e são produtos manufaturados, a partir de diferentes polímeros e de variadas formas de fabricação.

Os materiais constituintes das mantas de geotêxteis são polímeros, aos quais são acrescentados aditivos para melhorar as propriedades do produto final ou facilitar processos e operações de transformação, podendo exercer papel de lubrificantes, estabilizantes e plastificantes (Freitas, 2003).

Segundo Freitas (2003), os polímeros mais usados na fabricação de geotêxteis são os do grupo de termoplásticos, capaz de sofrer amolecimento ou endurecimento, sob ação da variação de temperatura, sem que haja comprometimento do material. Nesse grupo destacam- 
se o polietileno, poliamida (nylon), o poliéster (polietileno tereftalato) e o polipropileno. Assim as propriedades dos geotêxteis dependem das propriedades gerais dos polímeros usados e método de fabricação. Na Tabela 4.8 apresenta-se a comparação geral entre propriedades gerais dos polímeros.

Tabela 4.8 - Comparação entre propriedades gerais dos principais famílias de polímeros usados na fabricação de geotêxteis.

\begin{tabular}{l|c|c|c|c}
\hline & \multicolumn{4}{|c}{ POLÍMERO } \\
\hline PROPRIEDADES & Poliéster* & poliamida & polipropileno & polietileno \\
\hline Resistência & $\mathrm{A}$ & $\mathrm{M}$ & $\mathrm{B}$ & $\mathrm{B}$ \\
\hline Módulo de deformação & $\mathrm{A}$ & $\mathrm{M}$ & $\mathrm{B}$ & $\mathrm{B}$ \\
\hline Deformação na ruptura & $\mathrm{M}$ & $\mathrm{M}$ & $\mathrm{A}$ & $\mathrm{A}$ \\
\hline Fluência & $\mathrm{B}$ & $\mathrm{M}$ & $\mathrm{A}$ & $\mathrm{A}$ \\
\hline Peso específico & $\mathrm{A}$ & $\mathrm{M}$ & $\mathrm{B}$ & $\mathrm{B}$ \\
\hline Custo & $\mathrm{A}$ & $\mathrm{M}$ & $\mathrm{B}$ & $\mathrm{B}$ \\
\hline
\end{tabular}

RESISTÊNCIA A:

\begin{tabular}{l|c|c|c|c}
\hline Raio U.V. estabilizado & A & M & A & A \\
\hline Raio U.V. não estabilizado & A & M & M & B \\
\hline Álcalis & B & A & A & A \\
\hline Fungos, vermes, insetos & M & M & B & B \\
\hline Óleos & M & M & A & A \\
\hline Detergentes & A & A & A \\
\hline
\end{tabular}

Notas: A - Alta, M - Média, B - Baixa, U.V - radiação ultra-violeta.

* Polímero constituinte principal de geotêxteis usados nos Leitos de drenagem.

Fonte: Freitas (2003).

A estrutura do geotêxtil é determinada pela técnica utilizada na fabricação, ou seja, no processo de combinação das fibras, o qual pode dar origem a três tipos: tecidos, não-tecidos e tricotados.

Os geotêxteis tecidos são fabricados pelo processo de tecelagem, em que o arranjo dos fios é ordenado, com entrelaçamento dos mesmos em duas direções. Os geotêxteis nãotecidos são obtidos pela distribuição aleatória de fibras (monofilamentos contínuos ou cortados), sem direções preferenciais e interligados por processos que envolvem ação mecânica/agulhagem, térmica ou química. Os geotêxteis não-tecidos por apresentar uma 
estrutura mais complexa que os tecidos, quando utilizados como filtros, não atuam como uma simples face e sim como um meio tridimensional, visto que a espessura torna a ser um parâmetro adicional. Têm-se ainda os geotêxteis tricotados obtidos pela associação de técnicas de tricotagem e tecelagem na urdidura (Freitas, 2003).

Para a correta utilização dos geotêxteis é preciso avaliar as propriedades essenciais para a sua sobrevivência durante a instalação e vida útil. Os geotêxteis em uso estão sujeitos a diversos processos de degradação, destacadamente ataques mecânicos e químicos.

$\mathrm{O}$ ataque mecânico pode se dar por ação abrasiva por intermédio de agentes externos e/ou durante manipulação do produto. $\mathrm{O}$ ataque químico pode ocorrer do contato com substancias agressivas, tais alterações químicas podem resultar no inchamento das fibras, perda de material do polímero ou dos aditivos comprometendo a resistência e durabilidade das fibras. Porém, com o desenvolvimento de aditivos, tem-se diminuído a susceptibilidade dos polímeros aos ataques químicos. Outra forma de ataque aos geotêxteis, consiste de ataques biológicos que não deixa de ser ataque químico, mediante ação de fungos e bactérias.

\subsubsection{Mecanismos de Filtração em Geotêxteis}

Para o estudo de manta geotêxtil atuando como elemento filtrante é necessário o conhecimento das seguintes propriedades hidráulicas:

- Permeabilidade normal à manta: A permeabilidade permite avaliar a facilidade com que o fluido passa através de um meio poroso. Entretanto, nem sempre o fluxo através de um geotêxtil obedece a Lei de Darcy (Equação 4.10) ou pode-se dizer que a permeabilidade é constante, visto o fluxo não ser laminar (Freitas, 2003).

Lei de Darcy para geotêxteis:

$$
\mathrm{Q}=\mathrm{K} . \mathrm{i} \cdot \mathrm{A}=(\mathrm{K} . \Delta \mathrm{h} . \mathrm{A}) / \mathrm{Tg}
$$

Em que: $\quad \mathrm{Q}=$ volume do fluxo por unidade de tempo; 
$\mathrm{K}=$ coeficiente de permeabilidade de Darcy;

$\mathrm{I}=$ gradiente hidráulico;

$\mathrm{A}=$ área transversal total disponível para o fluxo;

$\Delta \mathrm{h}=$ variação de carga hidráulica;

$\mathrm{Tg}=$ comprimento do caminho do fluxo onde ocorre $\Delta \mathrm{h}$, ou seja, espessura do geotêxtil.

Os métodos de determinação de permeabilidade em geotêxteis ainda são muito discutíveis. Em geral, consistem de métodos que usam amostras de uma camada ou camadas empilhadas de geotêxteis, submetidas a uma diferença de carga hidráulica reduzida, que resulte em baixas velocidades de fluxo de forma a caracterizar o fluxo laminar. A permeabilidade pode variar com a tensão normal aplicada, em função da espessura deformável das mantas não-tecidas, o que, muitas vezes, impossibilita a adequada comparação entre diferentes geotêxteis. Logo, fez-se necessário a criação e adoção do termo permissividade, de forma a minimizar a influencia da espessura das mantas. A permissividade é dada pela Equação 4.11.

$$
\Psi=\mathrm{Q} / \mathrm{A} \cdot \mathrm{h} \text { ou } \Psi=\mathrm{K} / \mathrm{Tg}
$$

Em que:

$$
\begin{aligned}
& \Psi=\text { permissividade; } \\
& \mathrm{K}=\text { coeficiente de permeabilidade normal ao plano do geotextil; } \\
& \mathrm{Tg}=\text { espessura do geotêxtil. }
\end{aligned}
$$

- Permeabilidade no plano da manta ou transmissividade: Segundo Gomes (2002) é definido como a capacidade de fluxo hidráulico no plano do geotêxtil. A medição é feita mediante determinação da vazão através de corpo de prova, em função da tensão normal e do gradiente hidráulico, para geotêxtil posicionado entre duas superfícies de compressibilidade definida em norma, conforme pode ser observado na Figura 4.11. 


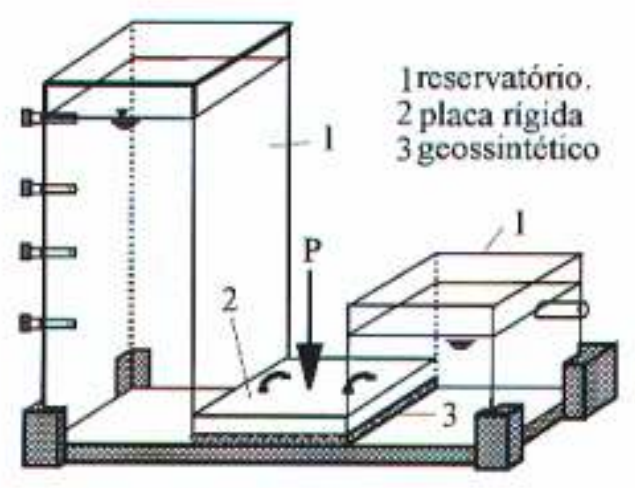

Figura 4.11 - Esquema ilustrativo para medição de permeabilidade no plano Fonte: Gomes (2002)

- Porosidade, Porometria e abertura de filtração: A porosidade pode ser definida como a relação de volume de vazios e volume da amostra e Porometria como a medida das dimensões dos poros e sua distribuição. O tamanho da abertura de filtração é definido como a abertura do geotêxtil equivalente ao maior diâmetro de partícula que consegue passar através do geotextil. O tamanho da abertura de filtração é o índice mais usado para definir o potencial de filtração, sua obtenção pode ser feita por diversos procedimentos ainda discutíveis, como análise de imagem e técnicas de peneiramento, sendo a técnica do peneiramento o mais difundido, principalmente para o caso de mantas geotêxteis não-tecidas.

Diversos autores Sampaio et al. (2000), Freitas (2003), Urashima e Vidal (1995), reportam a dois tipos básicos de mecanismos de filtração através de mantas sintéticas, em função das diferentes condições de interação sólidos/geotêxtil:

- Filtração de partículas em suspensão;

- Filtração em meio poroso.

Neste trabalho só será discutido a filtração em suspensão.

Segundo Freitas (2003), a filtração de partículas em suspensão é o caso da filtração de um líquido que contém, em suspensão, partículas finas que não estão em contato entre si ou 
não apresentam uma estrutura rígida organizada. A maior efíciência de retenção do filtro ocorre quando a manta é colocada transversalmente ao fluxo.

O dimensionamento de filtros têxteis é, em essência, o mesmo que o de filtros granulares, pois ambos têm estruturas similares: o geotêxtil possui seus poros e filamentos, enquanto os filtros granulares possuem seus vazios e partículas. No entanto, para os geotêxteis, a relação entre filamentos e poros é mais complexa do que nos filtros granulares devido ao formato e compressibilidade da estrutura porométrica das mantas têxteis.

Conforme Sampaio et al. (2001), os critérios de retenção usualmente utilizados no dimensionamento de filtros baseiam-se na proposta de Terzaghi, empírica ou semiempiricamente adaptada por diferentes autores. Estes consideram que o maior poro do geotêxtil deve ser menor que o produto entre determinado diâmetro de partícula e um fator. Os autores consideram diferentes solicitações e parâmetros de ensaios, sem correlação direta. Estes procedimentos deixam bastante obscuro o fenômeno da filtração, o que dificulta o cálculo da espessura da manta têxtil necessária para retenção de determinadas partículas.

Diante do exposto, a explicação dos mecanismos de filtração em mantas geotêxteis usadas como elemento filtrante nos Leitos de Drenagem pode ser realizada da seguinte forma:

O desaguamento dos lodos de ETAs por Leito de Drenagem mediante separação da fase liquida (água livre) e fase sólida (partículas) pode ser entendida como filtração de partículas em suspensão. Segundo Freitas (2003) esse tipo de filtração é um problema crítico. [...] Quando a partícula carreada encontra o filtro, ela tende a se depositar em sua superfície, o que ocorre mesmo para partículas muito pequenas, bem menores que a abertura de filtração do elemento filtrante, acarretando assim uma perda de carga no sistema [...] (FREITAS, 2003, p. 30).

Nesse caso, o problema de colmatação pode ter enorme importância, principalmente dependendo do tipo de material a ser filtrado e das características reológicas (viscosidade, concentração de sólidos e distribuição de tamanho de partículas). 
Pela teoria de filtração é de se esperar que a ação de um gradiente hidráulico provoque o fluxo de água, que por sua vez, causa rearranjo das partículas em suspensão que juntamente com a ocorrência da sedimentação evidencia dois mecanismos, a autofiltração e a formação de uma rede de arcos. Na autofiltração, a ação de filtro não se restringe apenas ao geotextil, mas propaga à camada adjacente, formando uma espécie de pré-filtro.

As partículas retidas adjacentes às aberturas superficiais, conforme pode ser observada na Figura 4.12, tendem a redistribuir as tensões verticais devido à força de percolação e força da gravidade, formando arcos que dificultam a passagem de partículas com diâmetros menores que das aberturas. A presença desses arcos foi confirmada por Rollin e Lombard ${ }^{5}$ apud Freitas (2003), a partir de análise de imagens.

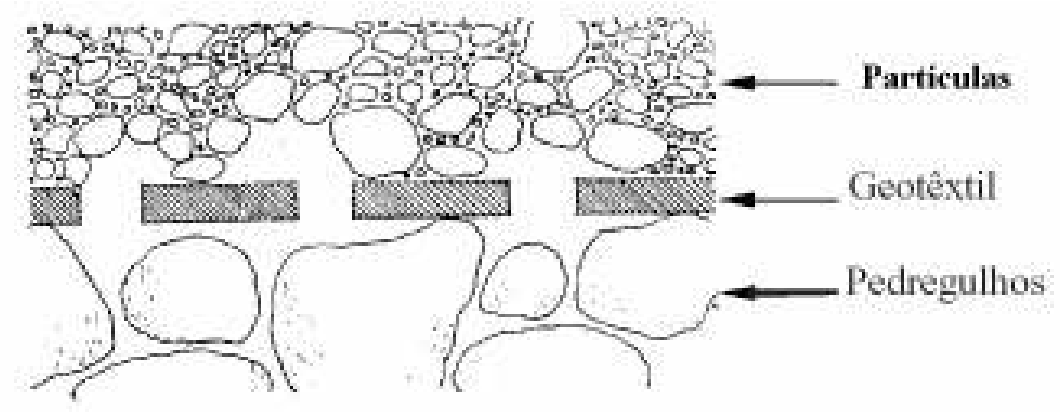

Figura 4.12 - Esquema ilustrativo da formação de rede de arcos na superfície dos poros de mantas geotêxteis.

Fonte: Freitas (2003) - adaptado.

Outro aspecto importante é observar a eficiência do sistema filtrante, constituído por geotêxteis, de manter a capacidade drenante/filtrante ao longo do tempo. Aspecto este intimamente relacionado com a ocorrência de colmatação.

A colmatação ocorre quando as partículas carreadas pelo fluxo são depositadas na interface do filtro, ou movidas para o interior do mesmo, constituindo uma zona de menor

\footnotetext{
${ }^{5}$ ROLLING, A. L., LOMBARD, G., (1988). Mechanisms affecting long-term filtration behavior of geotextiles. Geotextiles and Geomembranes, v. 7, pp. 119-145.
} 
permeabilidade que na região de fluxo livre anterior ao filtro e resulta na alteração das propriedades do geotêxtil ao longo do tempo.

O fenômeno da colmatação afeta diretamente a capacidade drenante do meio poroso onde ocorre o fluxo, fazendo-a diminuir à medida que os espaços disponíveis diminuem. De maneira geral, uma colmatação branda sempre é prevista. Freitas (2003) cita que $75 \%$ dos poros de mantas geotexteis podem estar colmatados sem comprometer o seu funcionamento.

As causas da colmatação podem ser físicas, químicas ou químico-biológicas e em determinadas situações podem ocorrer simultaneamente.

A causa física mais comum da colmatação é devido à ação de um gradiente hidráulico sob o sistema meio/geotêxtil que provoca um fluxo unidirecional e apresenta-se em três formas distintas denominadas bloqueamento, cegamento e colmatação propriamente dita.

Bloqueamento: As partículas se posicionam sobre as aberturas de geotêxtil obstruindo totalmente ou parcialmente, conforme ilustra-se na Figura 4.13. É importante notar que o bloqueamento é independente do tempo.

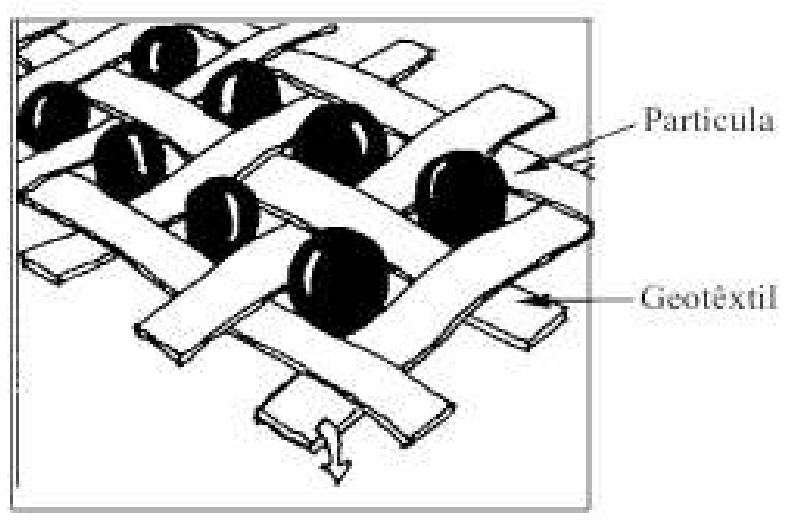

Figura 4.13 - Desenho esquemático do bloqueamento em geotêxtil. Fonte: Rollin e Lombard apud Freitas (2003)

Cegamento: As partículas finas migram em direção ao geotêxtil. Caso a porometria do geotêxtil não seja suficiente para permitir a passagem dessas partículas, estas se agruparão e 
formarão uma camada de baixa permeabilidade sobre a face do geotêxtil, afetando profundamente a capacidade drenante do mesmo, conforme apresenta-se na Figura 4.14.

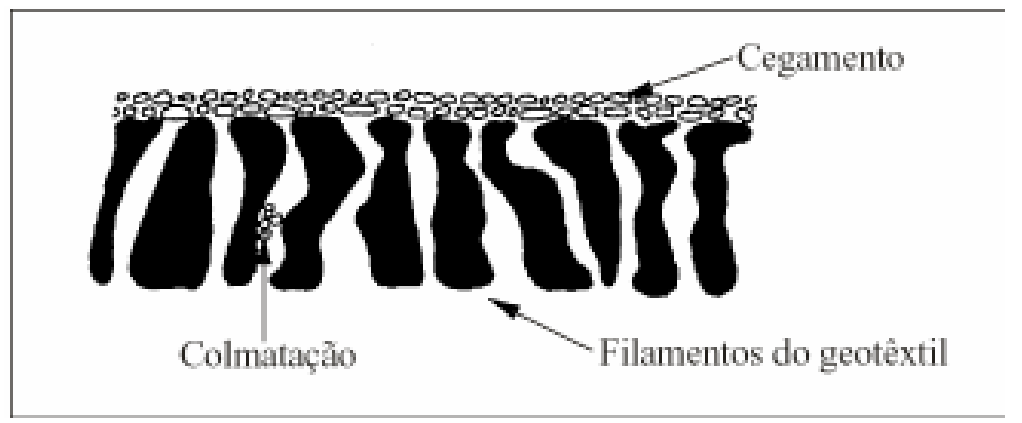

Figura 4.14 - Desenho esquemático do cegamento em geotêxteis.

Fonte: John (1987)

Colmatação propriamente dita: Partículas com diâmetros próximos às aberturas do geotêxtil migram junto com o fluido percolante, penetram no geotextil e ficam retidas no seu interior ao longo da espessura, conforme ilustrado na Figura 4.15.

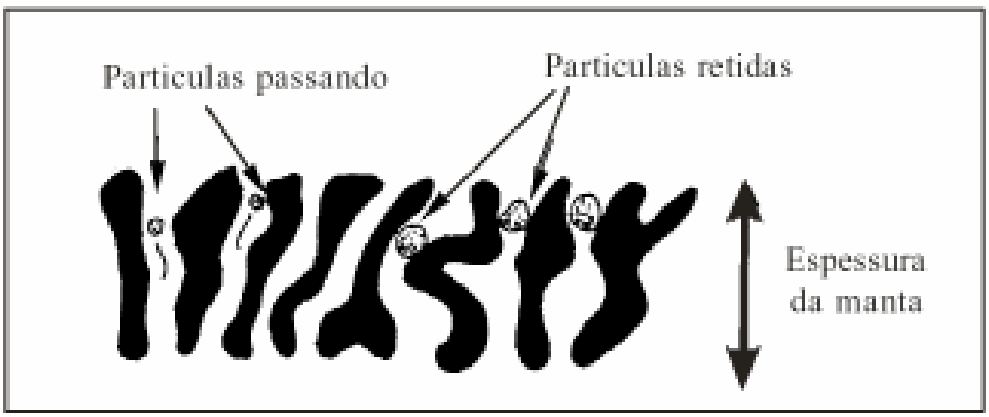

Figura 4.15 - Desenho esquemático da colmatação propriamente dita em geotêxteis.

Fonte: John (1987)

A causa química para a colmatação é resultante de carbonatos e sulfatos dissolvidos no fluido que atravessa o geotextil e formam cristais de sais que ocupam os espaços vazios nos meios porosos, quando a água evapora sob condições atmosféricas. Assim, problemas devido às características dos fluidos, tais como elevada alcalinidade, águas duras e variação de $\mathrm{pH}$ podem interferir na capacidade drenante de diferentes tipos de geotêxteis. Há também, a colmatação resultante de atividade microbiana promovendo o crescimento de biofilmes, com 
redução dos espaços vazios e/ou promovendo reações de oxidação e redução com formação de precipitados.

Dessa forma, inúmeros aspectos devem ser observados quando do uso de geotêxteis para determinados fins, como no caso do uso como elemento filtrante de resíduos de ETAs.

\subsection{Análise Crítica}

No desenvolvimento da revisão bibliográfica, bem como ao longo da pesquisa constatou-se inúmeras dificuldades em reunir informações e princípios entre as diferentes áreas do conhecimento concernentes ao tema abordado.

A questão dos resíduos gerados em ETAs, mais especificamente o lodo, tem sido objeto de recentes estudos, mas ainda incipientes. As peculiaridades características dos problemas envolvidos no gerenciamento e tratamento desses resíduos têm sido obstáculos no entendimento da eleição da melhor abordagem investigativa, científica e das ferramentas que podem auxiliar nesse sentido. Não só entendimento das ferramentas, ou seja, das técnicas usadas no estudo dos resíduos de ETAs, mas como adaptar e interpretar tais conhecimentos adquiridos tem se tornado o maior desafio.

O caráter transversal, adotado e presente nesse estudo faz saltar aos olhos esses aspectos supracitados. Talvez a linguagem, muitas vezes destoantes e a capacidade de troca de informações entre as diversas áreas do conhecimento no Brasil, tenham sido determinantes para as dificuldades encontradas. Parte também devido a limitações do próprio autor.

O necessário conhecimento das propriedades das frações sólidas e liquidas, bem como da combinação destas duas frações, apontam cada vez mais no sentido de incorporar conhecimentos das áreas de pesquisa de materiais, tais como cerâmicas, compósitos, mineração etc e das áreas de geotecnia e de estudo sobre reologia. 
Os avanços tecnológicos relativos a métodos de análises da matéria encontrados em outras áreas de conhecimento, como o caso da microscopia eletrônica de varredura acoplado a espectroscopia por dispersão de energia de Raios X (MEV/EDS), difração de Raios-X, técnicas de distribuição de tamanho de partículas e, viscosímetros ou medidores rotacionais entre outros podem contribuir para que a área do saneamento saia da era das "caixas pretas", que tanto tem limitado o desenvolvimento de operações e processos, para a compreensão dos mecanismos envolvidos, e tornar mais efetivas pesquisas nessas áreas, e mais particularmente no estudo das técnicas de redução de volume, tratamento e reutilização de lodos de ETAs. 


\section{Procedimentos Metodológicos}

\subsection{Generalidades}

O desenvolvimento da pesquisa e, mais particularmente, dos procedimentos metodológicos foi realizado com base na identificação das necessidades, identificação do tema, do problema e por fim na delimitação ou solução do problema.

A identificação do problema de redução de volume de resíduos de ETAs e busca de solução, pode ser melhor abordada ao considerar o resíduo ou lodo de ETAs como um volume constituído de fração sólida mais frações de água. As frações de água são: água livre, água intersticial, água vicinal e água de hidratação-pontes de hidrogênio, (Vesilind e Hsu, 1997); (Smollen e Kafaar, 1994).

Para a remoção de cada fração de água é necessário uso de uma determinada intensidade de energia $\boldsymbol{E}_{\boldsymbol{i}}$, conforme observa-se na Figura 5.1.
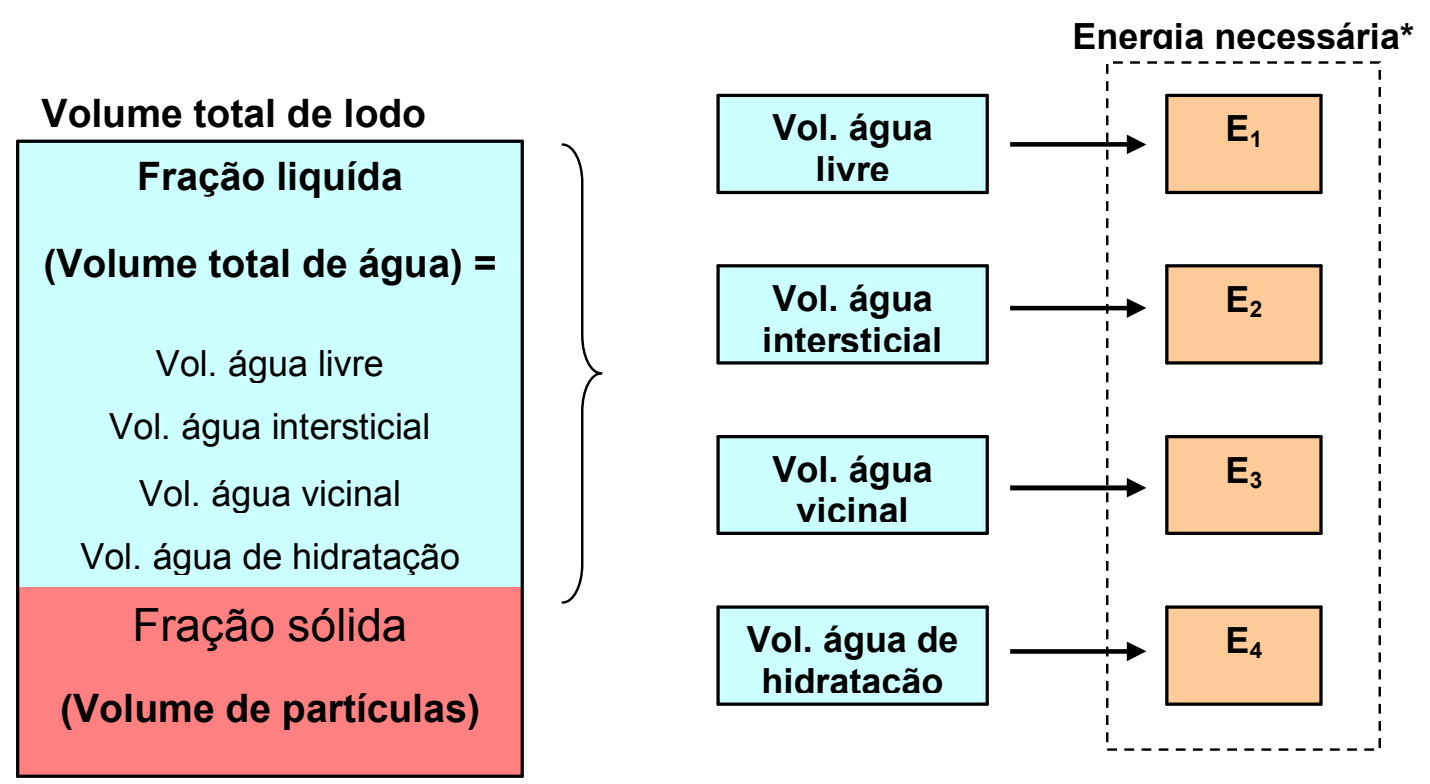

Figura 5.1 - Ilustração esquemática de energia requerida Ei para remoção dos diferentes volumes de frações de água constituintes de lodo de ETAs.

* Ei $=$ Energia requerida. 
A energia $\boldsymbol{E}_{\boldsymbol{l}}$ pode ser considerada energia decorrente da ação da gravidade, necessária para remoção da fração de água livre, é menor que a energia $\boldsymbol{E}_{2}$, e muitas vezes menor que a energia $\boldsymbol{E}_{3}$ (energia térmica) capaz de remover a fração de água vicinal, bem como a energia $\boldsymbol{E}_{4}$ raramente atingida e capaz de remover a água de hidratação. Assim, $\boldsymbol{E}_{4} \gg>>\boldsymbol{E}_{1}$ implica conseqüentemente em custos envolvidos em $\boldsymbol{E}_{4}$ muito maiores que em $\boldsymbol{E}_{\boldsymbol{l}}$.

A partir dessa premissa, o desaguamento de lodos por Leito de Drenagem (sistemas naturais) pode significar o uso eficiente do recurso $\boldsymbol{E}_{\boldsymbol{l}}$ (força da gravidade), aliado a disponibilidade ilimitada e "gratuita" do recurso de energia térmica para secagem, proveniente da energia solar e capaz de suprir as demandas por $\boldsymbol{E}_{3}$ e (parcialmente $\boldsymbol{E}_{4}$ ). O uso racional dos recursos energéticos disponíveis, a compreensão dos fatores que influenciam no desaguamento de resíduos de ETAs através de sistemas naturais, em particular o Leito de Drenagem impõe-se como uma necessidade estratégica de abordagem.

Dessa forma, admitiu-se, na proposição desta pesquisa, a subdivisão em duas fases de maneira a seguir uma seqüência lógica que permitisse a aquisição de conhecimento e procedimentos pertinentes ao desaguamento de lodos de ETAs por sistemas naturais e por último, a aplicação e manipulação destes conhecimentos e procedimentos no desaguamento por Leito de Drenagem. A investigação da influência dos recursos energéticos naturais fez-se mediante a avaliação de variáveis climatológicas.

Para avaliar as características dos resíduos de ETAs e do desaguamento por leito de drenagem foram coletadas amostras de lodos de decantadores provenientes de ETAs que usam distintos coagulantes. As ações e procedimentos realizados com os lodos obtidos de cada ETA são apresentados na Tabela 5.1. 
Tabela 5.1 - ETAs envolvidas no desenvolvimento da pesquisa e respectivas ações e procedimentos realizados.

\begin{tabular}{|l|l|}
\hline ETAs & Ações e Procedimentos \\
\hline A & $\begin{array}{l}\text { Fornecimento de amostras de lodo de decantador (sulfato de alumínio) para estudos } \\
\text { das propriedades e aplicação nos ensaios de desaguamento por leito de drenagem. }\end{array}$ \\
\hline B & $\begin{array}{l}\text { Fornecimento de amostras de lodo de decantador (PACl) para estudos das } \\
\text { propriedades e aplicação nos ensaios de desaguamento por leito de drenagem. }\end{array}$ \\
\hline
\end{tabular}

Para facilitar a compreensão e ordenamento lógico optou-se por subdividir a pesquisa em duas fases, conforme observado na Figura 5.2.

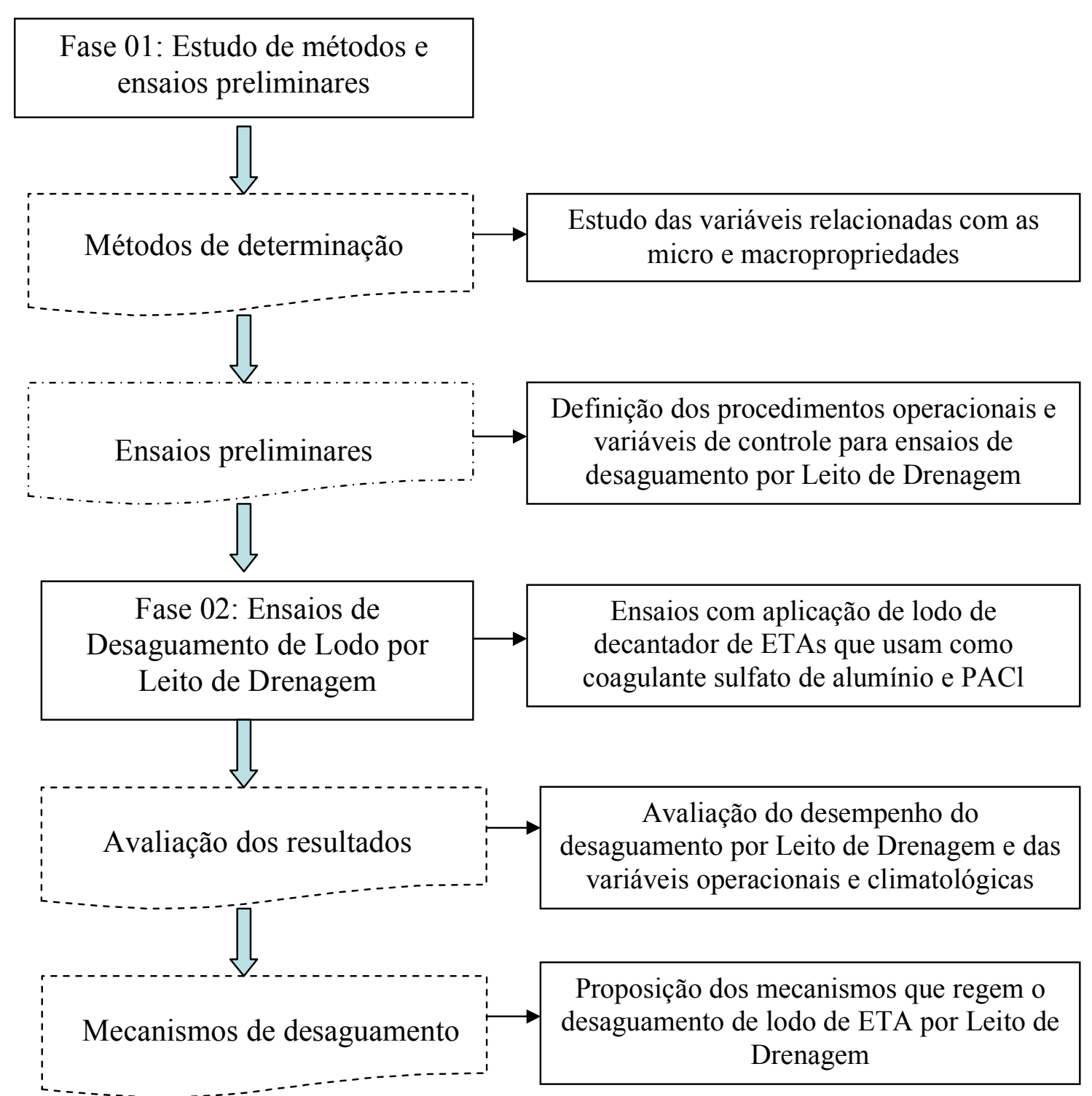

Figura 5.2 - Fluxograma dos Procedimentos Metodológicos adotados. 
Na Fase 01 realizaram-se estudos de técnicas e metodologias de determinação de variáveis a serem usadas na avaliação de desempenho do desaguamento por leito de drenagem. Num primeiro momento, foi previsto o estudo de variáveis relacionadas com as micropropriedades de resíduos de ETAs, proposto por Dentel (1997) e que também fazem parte de estudos reológicos, tais como frações de água, viscosidade, concentração de sólidos inicial e final, microscopia eletrônica de varredura, espectroscopia por dispersão de energia de Raios X, difração de Raios - X e distribuição de tamanho de partículas. Ademais, procurou-se estudar e adaptar metodologias para determinação de carbono orgânico total (COT). Na realização desta fase, constatou-se enorme dificuldade de comunicação entre as diferentes áreas do conhecimento abordadas.

Num segundo momento realizaram-se ensaios preliminares para definir os procedimentos operacionais e variáveis de controle relativos à fase subseqüente (Fase 02), de ensaios de desaguamento de lodos de ETAs por Leito de Drenagem.

Os procedimentos operacionais estudados consistiram de: teste de colocação e disposição da manta geotêxtil, forma de medição da vazão da água livre drenada e estudo das variáveis de controle, seja variação da massa ou volume de lodo introduzido, volume drenado com o tempo, vazão de drenagem e tempo de duração parcial e total de desaguamento.

No tocante às variáveis de controle, definiram-se a divisão da avaliação em duas etapas, conforme pré-determinado: Fase de drenagem e Fase de secagem. O término da fase de drenagem foi estudado e caracterizado para quando a vazão de drenado atingisse valores menores que $\mathrm{Q}=0,04 \mathrm{~L} / \mathrm{min}$, equivalente ao volume de $10 \mathrm{~mL}$ no intervalo de $15 \mathrm{~min}$.

O término da fase de secagem foi estudado e caracterizado para quando houvesse impossibilidade de coleta de sólidos retidos na manta, tamanho o "emaranhamento" entre sólidos e mantas ou atingisse o tempo estipulado de 7 dias. Além disso, definiram-se os procedimentos operacionais tais como, homogeneização, mecanismo de descarga e aplicação 
de lodo, forma de medição de vazão do drenado, concentração de sólidos ao longo do tempo, o volume de lodo aplicado, o volume acumulado de água drenado e o tempo total (fase de drenagem e fase de secagem) de remoção da água livre dos lodos.

Na Figura 5.3 apresenta-se um esquema ilustrativo do desenvolvimento dos ensaios e variáveis envolvidas. A partir desta figura são descritos os procedimentos e critérios adotados para realização dos ensaios preliminares.

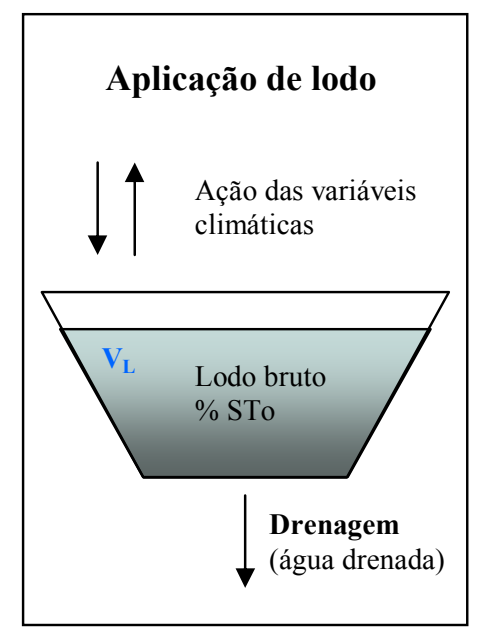

$\mathbf{t}_{\mathbf{0}}$

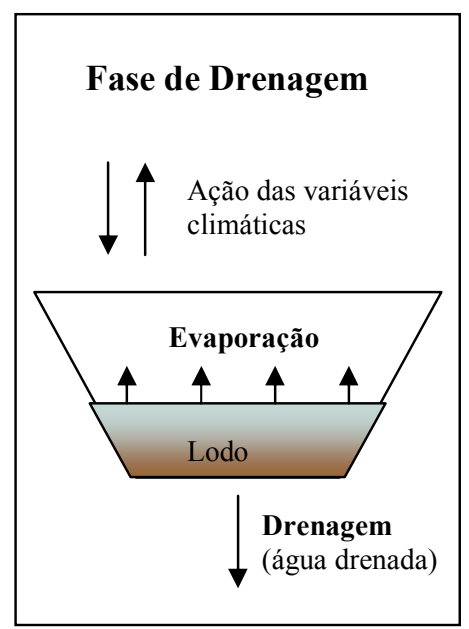

$\mathbf{t}_{\mathbf{i}}$

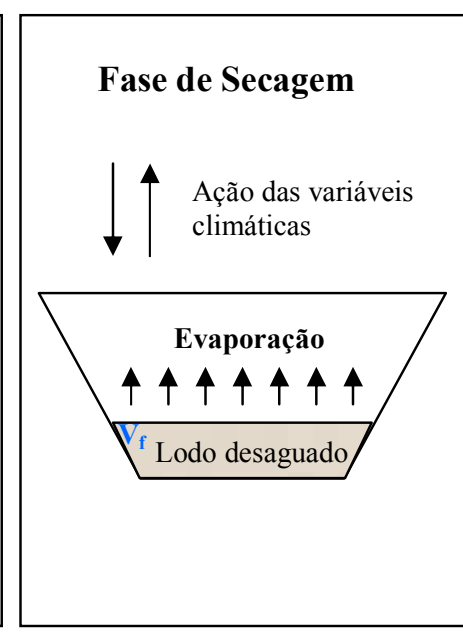

$\mathbf{t}_{\mathbf{f}}$

Figura 5.3 - Ilustração esquemática do ensaio de desaguamento por leito de drenagem e variáveis envolvidas.

Os ensaios tiveram início no tempo To, com a determinação do teor de sólidos inicial STo (\%) e medição do volume total de lodo aplicado $\mathrm{V}_{\mathrm{L}}$.

As variáveis de controle pré-definidas e estudadas são apresentadas a seguir:

- tempo total de desaguamento $(\Delta \mathrm{T})=\mathrm{T}_{\mathrm{f}}-\mathrm{T}_{\mathrm{o}}=\mathrm{T}_{\text {drenagem }}+\mathrm{T}_{\text {secagem; }}$;

- $\quad$ volume drenado acumulado $(\Delta \mathrm{V})=\mathrm{V}_{\mathrm{L}}-\mathrm{V}_{\text {evaporação }}+\mathrm{V}_{\text {precipitação; }}$

- variação de teor de sólidos total, $\Delta \mathrm{ST}(\%)=\mathrm{ST}_{\mathrm{i}}-\mathrm{ST}_{\mathrm{o}}$.

O conhecimento do valor de volume drenado com o tempo ou a redução de volume de lodo com o tempo permite estimar a variação da vazão ou taxa de drenagem de água livre 
$\left(Q_{d}\right)$. Após a realização dos ensaios preliminares foi confirmada a ocorrência de desaguamento em duas fases distintas:

a) Fase de drenagem - Ocorrência de efetiva drenagem de água livre através da ação filtrante da manta de geotêxtil e concomitante secagem por evaporação, mas com reduzida influência das variáveis climáticas.

b) Fase de secagem - Ausência de drenagem de água livre, a não ser quando há ocorrência de precipitação (chuva), com secagem predominantemente por evaporação por ação e influência das variáveis climáticas.

Dessa forma, os resultados da Fase 01 permitiram organizar e estruturar os procedimentos necessários para a realização dos ensaios de avaliação de desempenho e dos fatores intervenientes no desaguamento de lodo de ETAs por Leito de Drenagem a serem realizados na Fase 02 .

Na Fase 02 ocorreu a avaliação de desempenho do desaguamento de Lodos de ETAs por Leito de Drenagem em que se considerem as características intervenientes. Esta avaliação se fez a partir da abordagem individual e comparativa entre os dois lodos de coagulantes distintos, sulfato de alumínio e PACl.

Na Fase 02, o estudo foi dividido em seis etapas, apresentadas a seguir.

- Verificação das alternativas, e respectivas instrumentações existentes e necessárias, das estações climatológicas na região do município de São Carlos.

- Coleta das amostras de lodo;

- Caracterização e aplicação dos lodos de decantadores nos protótipos dos leitos drenagem, com monitoramento das variáveis operacionais e climatológicas;

- Coleta e caracterização do drenado e da fração sólida retida na manta geotêxtil;

- Tabulação e discussão dos resultados, considerando os dados das variáveis climáticas relativos ao período de ensaio. 
Os protótipos utilizados na realização dessa pesquisa foram colocados ao lado da Estação Climatológica da UFSCar. Os ensaios foram realizados simultaneamente em dois protótipos com capacidade para 240 litros.

\subsection{Coleta de Amostras}

Nas Fases 01 e 02, as amostras de resíduos, mais particularmente de lodo de decantadores, foram coletadas em ETAs que empregam como coagulantes, sulfato de alumínio e cloreto de polialumínio $(\mathrm{PACl})$ e, consecutivamente, caracterizadas e usadas nos ensaios de desaguamento. As amostras representam condições de diferentes coagulantes e demais características dos resíduos de ETAs.

Na Fase 01 foram realizadas três coletas de amostras de resíduos de decantadores para realização de ensaios preliminares e definição das metodologias de análises.

$\mathrm{Na}$ Fase 02 foram realizadas quatro coletas para a realização de ensaios de desaguamento por leito de drenagem.

As amostras dos lodos de decantadores foram coletadas em duas ETAs de ciclo completo, descritas na Tabela 5.2. Em cada ETA coletaram-se entre $50 \mathrm{~L}$ a $100 \mathrm{~L}$ de volume de amostra.

Tabela 5.2 - Estações de Tratamento de Água onde foram coletadas as amostras de lodo de sulfato de alumínio e de PACl.

\begin{tabular}{c|l|l|l|l}
\hline ETA & Vazão (L/s) & Coagulante & Tratamento de lodo & Descarte de lodo \\
\hline A & 500 & Sulfato de Alumínio & Não possui & Córrego Monjolinho \\
\hline B & 260 & Cloreto de Polialumínio & Não possui & Ribeirão Avecuia \\
\hline
\end{tabular}

Na seleção das ETAs para fornecimento das amostras, a ETA B, localizada no estado de São Paulo, se constituiu no caso típico, objeto dessa pesquisa. A referida ETA empregava até pouco tempo, sulfato de alumínio como coagulante. A crescente degradação da água bruta, principalmente com a elevação de matéria orgânica, limitou a eficiência requerida para atender o padrão de potabilidade tornando-se necessário avaliar alternativas, entre as quais, 
optou-se pelo uso de cloreto de polialumínio - PACl. A alteração do tipo de produto químico aplicado como coagulante promoveram mudanças nas características dos resíduos gerados. Os administradores responsáveis pela operação da ETA durante as tentativas de substituição do sulfato de alumínio pelo $\mathrm{PACl}$ constataram que a operação da ETA foi alterada. O uso de PACl promoveu formação de "grânulos" e diminuiu a carreira de filtração. Contudo, com a troca de fabricante do $\mathrm{PAC} \ell$ não ocorreu mais a formação de grânulos e conseqüentemente o comprometimento dos filtros. A ocorrência desses grânulos pode ter relação com impurezas, mas não foi investigado na realização dessa pesquisa.

\subsection{Condicionamento das Amostras}

Considerando o foco da pesquisa em sistemas naturais, a pretensão de evitar o crescente uso de produtos químicos e o caráter acessório desse item, optou-se, baseado na literatura correlata (Di Bernardo, 2005; Silva Junior, 2003), por usar, nos ensaios, somente polímeros aniônicos de elevada massa molecular como teste de condicionamento químico. Assim, o polímero foi aplicado nas amostras de lodo, inicialmente com concentração de $0,5 \%$. Contudo, a suspensão ficou muito viscosa tornando seu manuseio difícil. Então, optou-se por preparar polímeros concentrados a $0,25 \%$ e $0,1 \%$, adotando-se por fim $0,1 \%$.

As suspensões de polímeros a $0,1 \%$ foram preparadas, antes dos ensaios, como segue:

1. Pesava-se $250 \mathrm{mg}$ do polímero.

2. Colocava-se os $250 \mathrm{mg}$ de polímero dentro de um balão volumétrico de $150 \mathrm{~mL}$, com $25 \mathrm{~mL}$ de água deionizada para evitar absorção do polímero na parede da vidraria.

3. O balão era posto em uma balança e esta tinha sua tara medida.

4. Adicionava-se $1 \mathrm{~mL}$ de acetona.

5. Acrescentava-se água deionizada no balão, com o auxílio de uma pipeta, até que a balança indicasse o peso de $100 \mathrm{~g}$. 
6. Feito isto, colocava-se o balão sobre um agitador magnético, para que a suspensão de polímero ficasse completamente dissolvida e uniforme. A rotação do agitador era de aproximadamente, $25 \mathrm{rpm}$.

7. Após 90 minutos de agitação a suspensão estava pronta.

Nestes ensaios utilizou-se como agitador o equipamento de "jar test" LDB da Nova Ética, com uso de dois gradientes hidráulicos $600 \mathrm{~s}^{-1}$ e $800 \mathrm{~s}^{-1}$, escalonadas em intervalos de 5 minutos. Nos testes realizados nas colunas, verificou-se a dosagem de polímero de $1 \mathrm{~g} / \mathrm{Kg}$ de SST.

Os resultados dos ensaios realizados com e sem adição de polímeros mostraram que a adição de condicionantes químicos não representou melhoria significativa para o desaguamento em sistemas naturais. Por isso optou-se por não adicionar condicionamento químico nos ensaios.

\subsection{Instalações Experimentais}

Nas Fases 01 e 02 foram usados e testados três tipos de leitos de drenagem. O leito de drenagem com capacidade de 240 L (Leito de Drenagem I), leito de drenagem com capacidade de 10 L (Leito de Drenagem II) e Leito de Drenagem em acrílico com capacidade de 10 L (Leito de Drenagem III).

A partir dos ensaios preliminares realizados na Fase 01, foi definido o uso dos Leitos de Drenagem I e II para os ensaios da Fase 02.

Na Figura 5.4 é apresentada uma foto do protótipo do Leito de Drenagem I, usado neste trabalho durante as Fases 01 e 02 (a), e a vista geral do local onde foram instalados os protótipos do Leito de Drenagem I para a realização dos ensaios da Fase 02 (b), situados na estação climatológica localizada na UFSCar. 


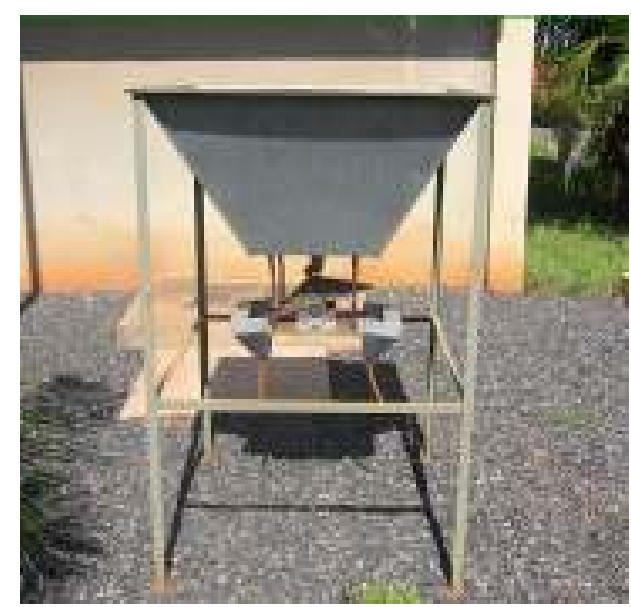

(a)

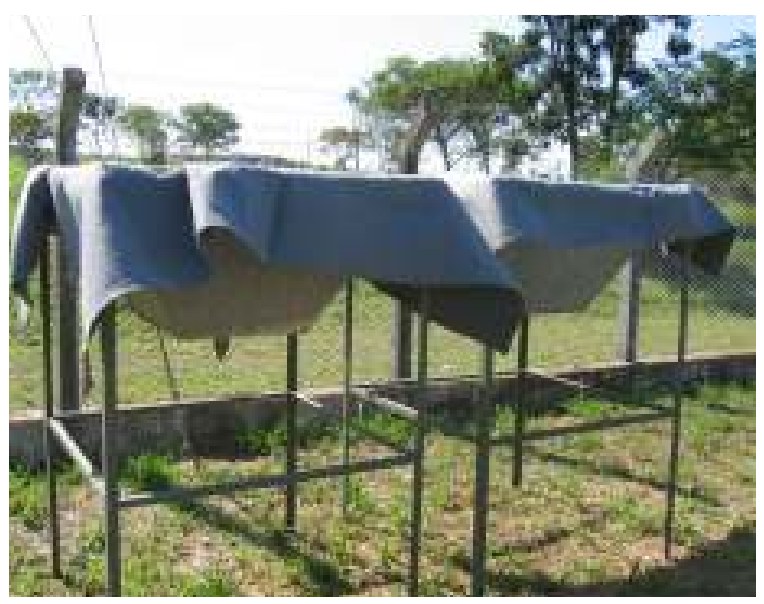

(b)

Figura 5.4 - (a) Protótipo de Leito de Drenagem I desenvolvido por Cordeiro (2001). (b) vista geral dos dois protótipos usados nos ensaios de desaguamento, situados na estação climatológica localizada na UFSCar.

As dimensões e configuração do protótipo são apresentadas na Figura 5.6.

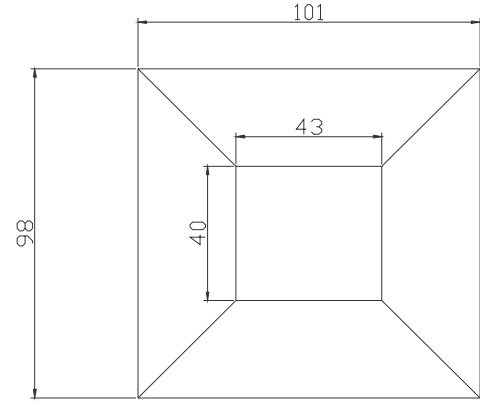

Planta baixa

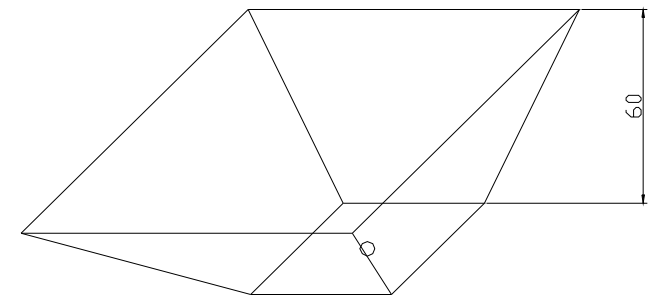

Vista perspectiva

Figura 5.5 - Ilustração do Leito de Drenagem I usado nos ensaios de desaguamento.

Na Figura 5.6 apresenta-se a fotografia dos protótipos do Leito de Drenagem II (a) e de leitos de drenagens em acrílicos, Leito de Drenagem III (b). O Leito de Drenagem II constitui de recipiente retangular em plástico com volume útil de aproximadamente $10 \mathrm{~L}$, área de fundo com dimensões $(0,20 \mathrm{~m}$ x $0,30 \mathrm{~m})$ e altura de $0,17 \mathrm{~m}$. O Leito de Drenagem III consiste de cilindros em acrílico com $0,15 \mathrm{~m}$ de diâmetro e $0,30 \mathrm{~m}$ de altura. Vale salientar, que os ensaios foram "normalizados" considerando a taxa de aplicação de sólidos. 


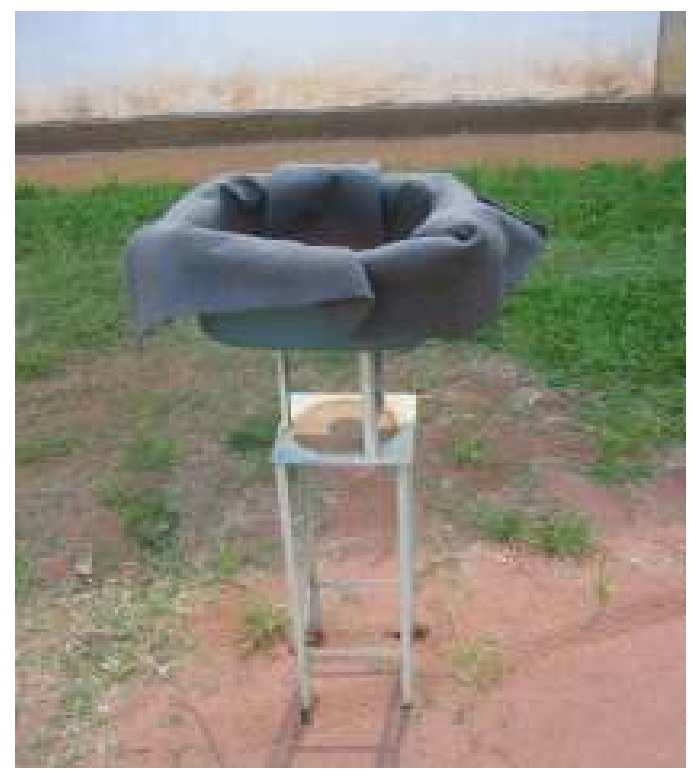

(a)

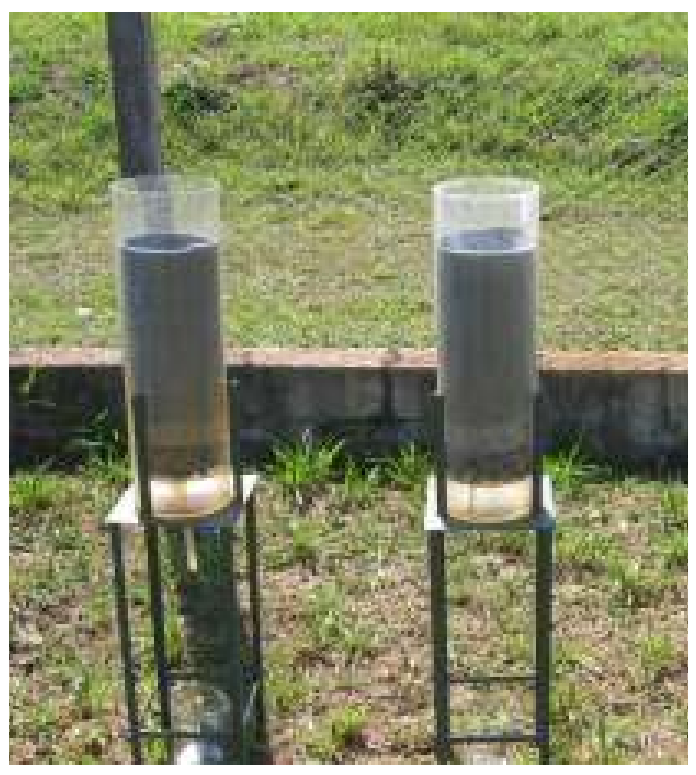

(b)

Figura 5.6 - Vista do Leito de Drenagem II com volume útil de 10 L usados nos ensaios de desaguamento na Fase 02 (a) e dos protótipos de acrílicos, Leito de Drenagem III, testados na Fase 01 (b).

A partir, das experiências relatadas em Cordeiro (2001), Achon e Cordeiro (2003) e realização dos ensaios preliminares da Fase 01, determinou-se a configuração definitiva dos leitos de drenagem I e II. Consistiu do Leito de Drenagem (I ou II), com área de fundo coberto com uma camada de cinco centímetros de brita 01 mais uma camada de manta geotextil, disposta no protótipo sem uso de qualquer tipo de emenda.

A manta geotêxtil escolhida para a realização dos ensaios tem densidade superficial de $600 \mathrm{~g} / \mathrm{m}^{2}$, que apresentou o melhor desempenho de drenagem nos experimentos realizados por Cordeiro (2001), Achon e Cordeiro (2003), e Fontana (2004). As características da referida manta são apresentadas na Tabela 5.3.

Tabela 5.3 - Características da manta geotêxtil utilizada nos ensaios de desaguamento.

\begin{tabular}{lcc}
\multicolumn{1}{c}{ Características da manta } & Unidades & $\mathbf{6 0 0 g} / \mathbf{m}^{\mathbf{2}}$ \\
\hline Espessura & $\mathrm{mm}$ & 4,5 \\
Porosidade & $\%$ & $>90$
\end{tabular}


Permeabilidade normal Abertura $\mathrm{cm} / \mathrm{s}$

$\mu \mathrm{m}$
$3 \times 10^{-1}$

60

Para o monitoramento das variáveis climatológicas foi verificado que no município de São Carlos há duas estações climatológicas clássicas e uma estação agrometereológica, dentre as quais foi escolhida a estação climatológica clássica completa localizada na Universidade Federal de São Carlos (UFSCar).

A estação climatológica clássica completa está sob controle do Instituto Nacional de Metereologia (CP São Carlos-N. 83726) em área concedida pela Universidade Federal de São Carlos (UFSCar).

A referida estação climatológica fornece a informação das seguintes variáveis: Pressão atmosférica, temperatura do ar, temperatura do bulbo úmido, temperatura máxima, temperatura mínima, umidade relativa do ar, direção e velocidade dos ventos, precipitação total, evaporação, insolação diária, nebulosidade, visibilidade, precipitação, gênero de nuvens e insolação horária. A descrição das variáveis climatológicas utilizadas nesse estudo e fornecidas pelo Instituto Nacional de Metereologia é apresentada na Tabela A1, Anexo A.

A caracterização das amostras e determinação das análises das variáveis de controle foram realizadas nas dependências do laboratório de Saneamento do Departamento de Engenharia Civil da UFSCar, Laboratório de Saneamento e LATAR-USP e as análises de partículas, difração de raio-X e MEV/EDS no Centro de Caracterização e Desenvolvimento de Materiais/CCDM - UFSCar/UNESP. 


\subsection{Ensaios de Desaguamento por Leito de Drenagem (Fase 02)}

Com os resultados obtidos na Fase 01 (fase preliminar), foram definidos os seguintes procedimentos operacionais para a realização dos ensaios de desaguamento de lodos de sulfato de alumínio e de PAC $\ell$ na Fase 02.

- homogeneização das amostras.

- medição de vazão do drenado com uso de recipientes com graduação volumétrica, uma vez que se fez necessária a caracterização de amostras em diferentes intervalos de tempo;

- obtenção da redução de volume de lodo mediante determinação da variação de volume acumulado de água livre drenada com o tempo;

- descarte de procedimento de avaliação da redução de volume de lodo através da leitura da altura de lodo. Houve inconveniência na medição da altura da massa de lodo, principalmente durante a fase de secagem, diante da formação de camada de lodo espesso com superfície irregular;

- tempo total de desaguamento foi definido com tempo de drenagem mais tempo de secagem.

$\mathrm{Na}$ Fase 03 foram realizados 6 ensaios com aplicação de 11 amostras no leito de drenagem. Cada ensaio realizado durou cerca de um mês, entre coleta, armazenamento e preparo das amostras e do leito de drenagem, realização efetiva do ensaio (aproximadamente sete dias) e análises em laboratório.

A caracterização das amostras de lodos foi realizada quanto ao teor de sólidos ST (\%), taxa de aplicação de sólidos TAS $\left(\mathrm{kg} / \mathrm{m}^{2}\right)$ e sólidos sedimentáveis.

Diante das distintas condições de ensaio de desaguamento em função dos diferentes volumes aplicados (altura da massa de lodo) e concentrações de sólidos iniciais, optou-se por 
calcular o valor da taxa de aplicação de sólidos, TAS em $\left(\mathrm{kg} \mathrm{ST} / \mathrm{m}^{2}\right)$ para todos os seis ensaios realizados ou onze amostras aplicadas.

Os cálculos das TAS são apresentados na Tabela A2, Anexo A, e foram realizados, a partir das seguintes considerações.

1. A área considerada no cálculo corresponde a área de fundo dos leitos de drenagem. Leito de Drenagem I com dimensões $(0,40 \times 0,43) \mathrm{m}^{2}$ e Leito de Drenagem II $(0,20 \times 0,30) \mathrm{m}^{2}$;

2. Adotou-se peso específico (adimensional) de 1,103 para os lodos de Sulfato de Alumínio e 1,095 para os lodos de $\mathrm{PAC} \ell$, baseado em valores comumente encontrados na literatura.

3. TAS ( $\mathrm{kg} / \mathrm{L})$ calculado a partir da massa de lodo, $m$, contida no volume de lodo aplicado, $v$, dividido pela área de fundo, $A_{f}$ dos protótipos de leito de drenagem.

As variáveis de controle do ensaio foram: teor de sólidos ao longo do tempo, volume de lodo aplicado, volume acumulado de água drenada, tempo de remoção da água livre dos lodos (tempo de drenagem).

Assim, na Fase de Drenagem foram determinadas as seguintes variáveis:

- vazão de drenagem e tempo de drenagem, Td;

- $\quad$ variação de teor de sólidos, (ST \%);

- variação de volume acumulado de água livre drenada que passa através do leito e respectivos valores de turbidez.

Na Fase de Secagem:

- variação do teor de sólidos, ST (\%), sendo $\mathrm{ST}_{\mathrm{o}}$ o valor de $\mathrm{ST}(\%)$ no fim da drenagem;

- variação do teor de sólidos e relação com as variáveis climáticas. 
De maneira geral, após a aplicação do lodo nos protótipos, procurou-se coletar amostras dos drenados nos tempos de $5 \mathrm{~min}, 15 \mathrm{~min}, 30 \mathrm{~min}, 45 \mathrm{~min}, 60 \mathrm{~min}$ e posteriormente a cada 60 minutos até encerrar a fase de drenagem. $\mathrm{O}$ volume drenado foi quantificado mediante uso de recipiente graduado com volume definido e dimensões conhecidas.

A água livre drenada (Fase de Drenagem) foi caracterizada quanto a turbidez, cor, sólidos totais, fixos e voláteis e metais, carbono orgânico total (COT) e demanda química de oxigênio (DQO).

Após o encerramento da fase de drenagem foram coletadas amostras de lodo desaguado retido na manta geotêxtil para determinação do teor de sólidos (\%). Esse valor de teor de sólidos foi considerado o teor de sólidos final da fase de drenagem e ao mesmo tempo, o inicial da fase de secagem e foi importante para estimar a eficiência da drenagem, bem como da evolução da secagem.

Após a secagem do lodo, as mantas foram retiradas com a massa seca de sólidos. As massas secas de sólidos foram coletadas e caracterizadas. As mantas usadas foram limpas com remoção superficial do resíduo retido e utilizadas novamente nos ensaios.

A avaliação qualitativa da Fase de Secagem foi realizada, a partir dos resultados de distribuição de tamanho de partículas e microscopia eletrônica de varredura acoplada a Espectroscopia por Dispersão de Energia de Raios-X (MEV/EDS) das amostras de lodo bruto e dos lodos desaguados retidos nas mantas geotêxteis, bem como as mesmas. As análises foram realizadas nas amostras coletadas ao fim da fase de secagem para os lodos de sulfato de alumínio (Ensaio 4) e de PACl (Ensaio 2).

A Tabela 5.4 mostra o resumo das variáveis operacionais e climatológicas usadas na avalição do desempenho do Leito de Drenagem no desaguamento dos lodos de Sulfato de Alumínio e de PACl. 
Tabela 5.4 - Variáveis operacionais e climatológicas monitoradas durante ensaios de desaguamento por leito de drenagem.

\begin{tabular}{|l|l|}
\hline VARIÁVEIS OPERACIONAIS & VARIÁVEIS CLIMATOLÓGICAS \\
\hline - tempo de drenagem (desaguamento); & - precipitação; \\
- tempo de secagem; & - taxa de evaporação; \\
- percentagem de variação de volume acumulado & - temperatura; \\
de água drenada por volume de amostra aplicada; & - umidade relativa do ar; \\
- taxa ou vazão de drenagem; & - insolação; \\
- variação do teor de sólidos totais; & - ventilação. \\
- taxa de aplicação de sólidos. & \\
\hline
\end{tabular}

\subsection{Caracterização "tradicional” das amostras de lodo de ETAs}

As variáveis e os métodos empregados para caracterização usual dos lodos de ETAs são descritos na Tabela 5.5, os quais seguiram os métodos preconizados pela APHA/AWWA/WEF (2005).

Tabela 5.5 - Variáveis e métodos utilizados para caracterização dos resíduos.

\begin{tabular}{l|l}
\hline Variáveis & Método \\
\hline $\mathrm{Ph}$ & APHA/AWWA/WEF, 2005 \\
\hline Teor de sólido total, em suspensão e dissolvido & APHA/AWWA/WEF, 2005 \\
\hline Sólidos sedimentáveis & APHA/AWWA/WEF, 2005 \\
\hline
\end{tabular}

\section{Teor de umidade, teor de sólidos e sólidos totais em base seca}

A determinação do teor de umidade, teor de sólidos e concentração de sólidos na base seca foi feita em duplicatas. Para cada análise, são medidos $40 \mathrm{~mL}$ de lodo, secos em estufa a $105^{\circ} \mathrm{C}$ até peso constante.

\subsection{Caracterização da água livre drenada dos ensaios de desaguamento por leito de drenagem}

As variáveis e os métodos analíticos usados para a caracterização e avaliação da qualidade da água livre drenada são descritos na Tabela 5.6, os quais seguiram os métodos preconizados pela APHA/AWWA/WEF (2005). 
Tabela 5.6 - Variáveis e métodos analíticos usados na caracterização da água livre drenada.

\begin{tabular}{l|l}
\hline Variáveis & Método \\
\hline $\mathrm{pH}$ & APHA/AWWA/WEF, 2005 \\
\hline Cor aparente $(\mathrm{uC})$ & APHA/AWWA/WEF, 2005 \\
\hline Turbidez (uT) & APHA/AWWA/WEF, 2005 \\
\hline Série de sólidos. & APHA/AWWA/WEF, 2005 \\
\hline Metais $(\mathrm{Cu}, \mathrm{Cr}, \mathrm{Fe}, \mathrm{Mn}, \mathrm{Ni}, \mathrm{Pb}$ e Zn) & APHA/AWWA/WEF, 2005, EAA \\
\hline
\end{tabular}

\subsection{Caracterização das micro e macropropriedades das amostras de lodos}

\section{de ETAs}

A caracterização das micro e macropropriedades dos lodos de sulfato de alumínio e de PACl foi realizada, a partir do estudo e uso dos métodos analíticos apresentados na Tabela

\section{7 .}

Tabela 5.7 - Micro e macropropriedades e métodos usados na caracterização não tradicional dos lodos de ETAs.

\begin{tabular}{l|l}
\hline Propriedades & Método \\
\hline Sedimentabilidade (lodo) & Coluna de sedimentação \\
\hline Frações de água (estudo) & Congelamento e descongelamento de lodo \\
\hline Distribuição de tamanho de partículas & SEDIGRAPH (esfera de diâmetro equivalente) \\
\hline Estrutura cristalina & Difraçao de Raios X (CCDM/UFSCar) \\
\hline Morfologia das partículas & $\begin{array}{l}\text { MEV - microscopia eletrônica de varredura } \\
\text { (CCDM/UFSCar) }\end{array}$ \\
\hline Avaliação qualitativa da fração solida & $\begin{array}{l}\text { EDS - Espectroscopia por Dispersão de Energia de } \\
\text { Raios-X (CCDM/UFSCar) }\end{array}$ \\
\hline Carbono orgânico total (lodo) & Adaptação de Moraes et al. (2003) \\
\hline Metais $(\mathrm{Cu}, \mathrm{Cr}, \mathrm{Fe}, \mathrm{Mn}, \mathrm{Ni}, \mathrm{Pb}$ e Zn) & APHA/AWWA/WEF, 2005, EAA \\
\hline
\end{tabular}

\subsubsection{Sedimentabilidade - Ensaios em Coluna de sedimentação}

A coluna utilizada para a realização do ensaio de clarificação por sedimentação da amostra, consistiu de provetas de $1000 \mathrm{~mL}$.

O ensaio de clarificação em coluna de sedimentação foi realizado com porção das amostras de lodo de sulfato de alumínio e de $\mathrm{PACl}$ previamente homogeneizadas e prontas para aplicação nos ensaios de desaguamento. 
Após a introdução da amostra de estudo na coluna de sedimentação, foram feitas leituras das alturas da interface de clarificação em intervalos de 15 min, 30 min, 45 min, 60 $\min , 120 \min , 24$ horas e 48 horas.

Com a construção das curvas de sedimentação calculou-se a velocidade de sedimentação máxima para cada ensaio realizado. A velocidade de sedimentação máxima, Vs foi determinada para quando à interface clarificado-lodo sedimentasse à velocidade constante, para um instante $t_{1}$ inicial a um instante $t_{2}$ em que há crescente diminuição da velocidade (ponto de inflexão da curva). A curva Altura da Coluna de Lodo X Tempo, neste intervalo, é um segmento de reta e a velocidade de sedimentação máxima é dada pelo coeficiente angular, conforme relatado no Capitulo 4, seção 4.4.3.2.

\subsubsection{Determinação das Frações de água do Lodo e ensaios de congelamento}

As frações de água seriam determinadas no laboratório de Engenharia Química da UFSCar, a partir de adaptação do método dilatométrico apresentado por Vesilind e Hsu (1997), conforme acordado com o professor João Batista Baumgartner (Departamento de Engenharia Química da UFSCar), mas diante da fatalidade e indisponibilidade financeira, a continuidade desses estudos foi comprometida.

O método baseia-se no não congelamento da água de ligação (água não livre) a temperaturas abaixo do ponto de congelamento da água livre. Estima-se a água total na amostra por evaporação (análise de sólidos secos) e então se mede o volume de água congelável, a $-20^{\circ} \mathrm{C}$ por dilatometria. Assim, a água de ligação é obtida pela diferença entre a água total e o volume de água congelável. Vale ressaltar que a água de ligação é constituída pelas frações de água vicinal e de hidratação. Sua estimativa fornece indiretamente o limite de desaguamento mecânico. Não sendo possível a realização de determinação das frações de água procedeu-se ensaios de congelamento de lodo de ETA. 
O ensaio de congelamento seguiu procedimentos adaptados de Martel et al. (1998). Consistiu em colocar aproximadamente $2 \mathrm{~L}$ de amostra em um recipiente circular de acrílico e dispô-los em congelador a temperaturas menores que $0^{\circ} \mathrm{C}$.

Quando a porção inferior do conjunto lodo mais recipiente de acrílico tornou-se transparente, significou que os cristais de gelo estavam formados e o congelamento completado. Na seqüência procedeu o descongelamento da amostra e realizou-se ensaio de sólidos sedimentáveis comparativamente com amostras brutas.

\subsubsection{Determinação de distribuição de tamanho de partículas (Fracionamento e SEDIGRAPH)}

No estudo das técnicas de determinação da distribuição de tamanho de partículas foi considerado a divisão em dois grupos: com e sem fracionamento da amostra. Nas técnicas com fracionamento, as partículas são removidas da amostra por faixas (frações) de tamanho, obtida após sucessivas etapas de separação.

Quando do uso de fracionamento por filtração em membranas ou papel de filtro, o tamanho das partículas foi relacionado ao diâmetro (abertura) do poro, ou seja, os resultados são expressos em esfera de diâmetro igual à abertura do poro.

Nesse sentido, realizaram-se ensaios preliminares para verificar o potencial uso de técnica de fracionamento por filtração em membranas ou papel de filtro para determinação de distribuição de tamanho de partículas de amostras de lodos de decantadores. Os ensaios foram realizados a partir da adaptação da metodologia proposta por Balmat (1957) e constituiu-se dos seguintes procedimentos apresentados na Tabela 5.8.

A motivação para realização destes ensaios baseados em Balmat (1957) consistia em obter uma metodologia apropriada e de baixo custo para ensaios de distribuição de tamanho de partículas. 
Tabela 5.8 - Procedimentos para determinação de distribuição de tamanho de partículas por fracionamento por filtração seqüencial com uso de membranas.

\begin{tabular}{l|c}
\hline \multicolumn{1}{c|}{ Procedimento } & Esfera de diâmetro equivalente \\
\hline 1. Sol. Sedimentáveis em cone Imhoff para $\mathrm{t}=1$ hora & $>100 \mu \mathrm{m}$ \\
\hline 2. filtração através de membranas & $>74 \mu \mathrm{m}$ \\
\hline 3. filtração através de membranas & $>53 \mu \mathrm{m}$ \\
\hline 4. filtração através de membranas & $>38 \mu \mathrm{m}$ \\
\hline 5. filtração através de membranas & $>8 \mu \mathrm{m}$ \\
\hline 6. filtração através de membranas & $>5 \mu \mathrm{m}$ \\
\hline 7. filtração através de membranas & $>1,20 \mu \mathrm{m}$ \\
\hline 8. filtração através de membranas & $>0,80 \mu \mathrm{m}$ \\
\hline 9. filtração através de membranas & $>0,45 \mu \mathrm{m}$ \\
\hline 10. filtração através de membranas & $>0,20 \mu \mathrm{m}$ \\
\hline 11. filtração através de membranas & $>20$ \\
\hline
\end{tabular}

Fonte: adaptado de Balmat (1957).

A partir dos procedimentos constantes na Tabela 5.8 e conhecendo os valores de volume e concentração de sólidos totais para cada fração, pode-se determinar a distribuição do tamanho de partículas considerando a abertura do poro e massa de partículas retida.

O ensaio de filtração foi realizado com equipamento de filtração usado para determinação de sólidos em suspensão, com uso também de bomba de vácuo. Vale dizer que o procedimento adotado foi de 10 segundos de funcionamento da bomba de vácuo de forma a minorar o efeito da força cisalhante nos flocos e partículas contidas no lodo.

$\mathrm{Na}$ realização destes ensaios constatou-se o dispendioso volume de trabalho e tempo requerido para realização deste método de análise e assim optou-se por se usar métodos de determinação automatizada com uso do equipamento SEDIGRAPH.

\section{Técnicas de distribuição de tamanho de partículas - SEDIGRAPH}

Esse ensaio exige que o material a ser analisado esteja em suspensão diluída (1\% de sólidos por volume). Para isso, o resíduo a ser analisado é seco em estufa, passado na peneira de $\mathrm{N}^{\mathrm{o}} 100$ - ASTM e determinado a densidade das partículas. Pesam-se 3 g de resíduo e 
adicionam-se $20 \mathrm{~mL}$ de água. Desagregam-se possíveis formações de aglomerados da amostra preparada, utilizando equipamento de ultra-som. A suspensão é então colocada no equipamento "Sedigraph", que reune um béquer, agitador magnético, uma ou duas bombas peristálticas, uma cela onde as partículas se sedimentam e uma fonte de raios X.

Na primeira etapa da análise, o Sedigraph mede a transmitância de raios $\mathrm{X}$ através da suspensão da amostra em movimento, de modo a não permitir nenhuma sedimentação. Em seguida, o equipamento interrompe o movimento da suspensão da amostra e permite que a sedimentação comece a ocorrer. A transmitância de raios X é, então, medida novamente nas diferentes posições na cela (medidas em relação ao topo da mesma) e nos tempos préselecionados com base na lei de Stokes (medidos a partir do momento em que a circulação da suspensão de amostra foi interrompida). As transmitâncias assim obtidas se relacionam à concentração de partículas com o exato diâmetro correspondente à distância e ao tempo de queda em que foram medidas. Dessa forma, para cada diâmetro desejado, o sedigraph fornece uma relação que, multiplicada por 100 , dá a porcentagem de partículas com diâmetro desejado.

O aparelho determina partículas com tamanhos entre 100 e 0,2 $\mu \mathrm{m}$. Entretanto como a técnica baseia-se na lei de Stokes, o equipamento não é capaz de descrever adequadamente a sedimentação de partículas abaixo de $1 \mu \mathrm{m}$, uma vez que estas são significativamente afetadas pelo movimento browniano e por correntes de convecção presentes na suspensão. Portanto, considerações comedidas devem ser feitas quando relacionadas com as frações de partículas com diâmetros equivalentes abaixo de $1 \mu \mathrm{m}$.

A realização das análises foi feita com o equipamento Sedigraph-5100, localizado no Laboratório de Cerâmicas do Departamento de Engenharia de Materiais da UFSCar. 


\subsubsection{Microscopia Eletrônica de Varredura acoplada a Espectrocopia por Dispersão de Energia de Raios-X - MEV/EDS}

Durante a incidência de um feixe de elétrons em uma amostra sólida ocorrem alguns processos de interação entre eles. Os diversos tipos de elétrons refletidos e os elétrons absorvidos são utilizados na microscopia eletrônica de varredura (MEV). Raios-X também são gerados nessa interação entre elétron e matéria, sendo que os mesmos são utilizados para identificar qualitativamente os elementos químicos presentes nas amostras.

Para a realização das análises de MEV/EDS, o resíduo, foi seco em estufa e passado na peneira $\mathrm{N}^{\mathrm{o}} 100$ (American Society for Testing Materials - ASTM), esse procedimento foi usado para as amostras de lodo bruto e amostras de lodo desaguado.

$\mathrm{Na}$ MEV realizada nas amostras de lodo, as micrografias foram obtidas a partir da emissão e detecção de elétrons secundários provenientes das amostras de massa de lodo. Tal informação é importante para caracterizar a geração de imagens com elevada resolução espacial (maior área de cobertura da amostra), porém com pouca profundidade. As micrografias obtidas por elétrons secundários foram consideradas adequadas, pois atende as necessidades de uma compreensão mais global da morfologia dos lodos de ETAs, porquanto não possuir fins específicos nesse sentido. O equipamento usado para realizar as análises foi um Microscópio Eletrônico de Varredura - MEV, modelo LEO Stereoscan 440.

A identificação qualitativa das amostras foi realizada via EDS. A análise via EDS é uma técnica que caracteriza os elementos presentes nas amostras, com limite de detecção de $0,1 \%$ de concentração em massa. O equipamento usado foi um detector para Espectroscopia por Dispersão de Energia de Raios X (EDS), modelo (Energy Dispersive Spectroscopy Oxford eXL) acoplado ao MEV. Os ensaios foram feitos no Centro de Caracterização e Desenvolvimento de Materiais/CCDM - UFSCar/UNESP. 


\subsubsection{Ensaio de Difração de Raios X}

$\mathrm{Na}$ metodologia de análise por difração de raios $\mathrm{X}$ (DRX), o sistema utiliza equipamentos de Raios X, com amostra em pó, cujo diagrama de refração é obtido através de registro gráfico com contador Geiger, chamado de difratograma de Raios X. Para a realização dos ensaios, o resíduo foi seco em estufa e passado na peneira $\mathrm{N}^{\circ} 100$ (American Society for Testing Materials - ASTM), em seguida a amostra em pó é colocada e fixada em lâmina de vidro. O aparelho de Raios $\mathrm{X}$ é acionado sobre a amostra e o difratograma é registrado no contador. Os ensaios foram feitos no Centro de Caracterização e Desenvolvimento de Materiais/CCDM - UFSCar/UNESP.

\subsubsection{Estudo de Metodologia para Determinação de COT em resíduos de ETAs}

Para a determinação de carbono orgânico total (COT) estudou-se a adaptação da metodologia desenvolvida por Moraes et al. (2003), empregada no Laboratório de Processos Biológicos - LPB/USP. O princípio da metodologia consiste em promover a "queima" da matéria orgânica e conseqüente liberação de carbono orgânico na forma gasosa em recipiente fechado para posterior leitura da concentração de COT, inicialmente com uso um analisador de COT EUROGLAS TOC 1200 onde não teve resultados satisfatórios, e depois através de cromatografia.

\section{Coleta e preparo das amostras}

As amostras foram coletadas em volumes de 10 a $25 \mathrm{~mL}$, acidificadas com ácido sulfúrico e submetidos ao ultra-som para retirada de carbono inorgânico. Para análises realizadas após 24 horas da coleta, procedeu-se o congelamento das amostras.

\section{Construção da curva de calibração}

Para o levantamento da curva de calibração e posterior determinação de COT realizouse a padronização dos volumes dos frascos usados para leitura das amostras no cromatógrafo. 
A padronização dos volumes dos frascos foi feita mediante adição de água e compensação das diferenças de volumes (ordem crescente) com uso de pérolas de vidro.

Para a construção das curvas de calibração utilizou-se solução estoque de ftalato $\left(\mathrm{C}_{8} \mathrm{H}_{5} \mathrm{KO}_{4}\right)$ para confecção dos padrões. Os padrões foram feitos em meio ácido (solução de $\mathrm{H}_{2} \mathrm{SO}_{4}$ ) e posteriormente aquecidos em banho de glicerina a $150^{\circ} \mathrm{C}$. A leitura dos padrões e das amostras foi realizada mediante uso de cromatógrafo localizado no Laboratório de Processos Biológicos do Departamento de Hidráulica e Saneamento - EESC/USP. 


\section{Resultados e Discussão}

Neste capítulo são apresentados e discutidos os resultados dos estudos e ensaios realizados de forma a verificar o desempenho do leito de drenagem no desaguamento de lodos de sulfato de alumínio e $\mathrm{PACl}$ e avaliar a influência das micro e macropropriedades.

A seção 6.1 corresponde a Fase 01 são apresentados os estudos das propriedades do lodo e respectivas técnicas de determinação:

- das frações de água que se desdobrou no estudo do potencial uso de técnicas de congelamento e descongelamento como condicionante ou espessador de lodos de ETAs;

- da distribuição de tamanho de partículas;

- de carbono orgânico total (COT) nas amostras de lodo.

Adicionalmente apresentam-se resultados dos ensaios preliminares que deram suporte a realização dos ensaios controlados de desaguamento realizados na seqüência, seção 6.2.

Na seção 6.2 (Fase 02) são apresentados os resultados encontrados para cada ensaio realizado, as particularidades envolvidas e consecutivamente a avaliação conjunta dos resultados que inclui a avaliação qualitativa da água livre drenada e da fração sólida (lodo desaguado).

\subsection{Fase 01: Estudo e definição das micro e macropropriedades e variáveis de controle usadas para realização de ensaios de desaguamento por Leito de Drenagem}

$\mathrm{Na}$ seção 6.1 (Fase 01) foram realizados ensaios de fracionamento por filtração seqüencial em múltiplas membranas com intuito de desenvolver técnica apropriada de determinação de distribuição de partículas para lodos de ETAs. Os estudos de determinação das frações de água e viscosidade aparente para lodos de ETAs foram prejudicados pela 
fatalidade do falecimento do professor João Batista Baumgartner (Departamento de Engenharia Química da UFSCar) principal parceiro nesses estudos e posteriormente por indisponibilidade financeira. A despeito dessas ressalvas são apresentados na seção 6.1.1, os resultados dos estudos para definição das metodologias de determinação das variáveis; distribuição de tamanho de partículas; frações de água (ensaios de congelamento e descongelamento) e teor de carbono orgânico total (COT).

Na seqüência, na seção 6.1.2, são apresentados os resultados referentes aos ensaios caracterizados como preliminares, de maneira a definir os procedimentos operacionais e variáveis de controle para realização de ensaios de desaguamento de lodos de ETAs por Leito de Drenagem.

\subsubsection{Estudo das técnicas de determinação das micro e macropropriedades.}

Essa fase compreendeu estudo de técnicas de determinação de características não tradicionais de lodos de ETAs. Constou de ensaios para determinação de distribuição de tamanho de partículas, em que concomitante foram realizados testes de congelamento do lodo como "alternativa de espessamento do lodo". Posteriormente foi estudado métodos de determinação de COT.

\subsubsection{Técnicas de determinação de distribuição de tamanho de partículas}

Realizaram-se ensaios preliminares para verificar o potencial uso de técnica de fracionamento por filtração em membranas ou papel de filtro para determinação de distribuição de tamanho de partículas de amostras de lodos de decantadores.

Os ensaios foram realizados entre os dias 2 e 7 de Julho de 2004, com amostras de lodos de sulfato de alumínio provenientes dos decantadores da ETA A. Homogeneizaram-se vinte litros de amostras, dos quais quatro litros foram usados no ensaio de sólidos 
sedimentáveis e caracterização da amostra, e parcela restante foi usada no ensaio de filtração fracionada e aproveitada para ensaio de congelamento de lodo.

Na Tabela 6.1 são apresentados os resultados obtidos nos ensaios de fracionamento de resíduos de ETAs, que encontram-se pormenorizados na Tabela A3, Anexo A.

Tabela 6.1 - Resultado dos ensaios de fracionamento de lodo de sulfato de alumínio, massa de partículas retidas $\mathrm{X}$ abertura de poro de membranas de filtração em $\mu \mathrm{m}$.

\begin{tabular}{|c|c|c|c|c|}
\hline \multirow{3}{*}{$\begin{array}{l}\text { Intervalos } \\
\text { Diâmetro da } \\
\text { abertura } \\
(\mu \mathrm{m})\end{array}$} & \multirow{2}{*}{\multicolumn{2}{|c|}{$\frac{\text { Ensaio 1 }}{(2 / 7 / 2004)}$}} & \multirow{2}{*}{\multicolumn{2}{|c|}{$\begin{array}{c}\text { Ensaio 2 } \\
(5 / 7 / 2004)\end{array}$}} \\
\hline & & & & \\
\hline & $\begin{array}{c}\text { massa de } \\
\text { partículas retida } \\
(\%)\end{array}$ & $\begin{array}{l}\text { massa acumulada de } \\
\text { partículas retida }(\%)\end{array}$ & $\begin{array}{c}\text { massa de } \\
\text { partículas retida } \\
(\%)\end{array}$ & $\begin{array}{l}\text { massa acumulada de } \\
\text { partículas retida }(\%)\end{array}$ \\
\hline$>74$ & 34,9 & 34,9 & 21,2 & 21,2 \\
\hline $53-74$ & 42,6 & 77,4 & 36,2 & 57,4 \\
\hline $38-53$ & 22,7 & 100,2 & 29,1 & 86,5 \\
\hline $20-38$ & ND & ND & 6,5 & 93,0 \\
\hline $8-20$ & ND & ND & 4,1 & 97,1 \\
\hline $5-8$ & ND & ND & 2,1 & 99,1 \\
\hline $1,2-5$ & ND & ND & 1,0 & 100,1 \\
\hline
\end{tabular}

ND - Não determinado

Houve inúmeros problemas de procedimento durante a realização dos ensaios, que podem ter comprometido a qualidade dos resultados. Os problemas podem ser elencados como: a colmatação rápida e excessiva das membranas, dificuldade de obter volume suficiente para permitir leitura ou determinação de sólidos e ocorrência de ruptura ou perfuração de membranas. A despeito dessas ressalvas pode-se citar, baseado na Tabela 6.1 e Figura 6.1, que em massa, cerca de 36 a $42 \%$ das partículas estão na faixa de 53 a $74 \mu \mathrm{m}$, e 22 a $29 \%$ estão na faixa de 38 a $53 \mu \mathrm{m}$. Deve-se lembrar que a literatura apresenta valores que costuma variar para $\mathrm{D}_{60}$ de 10 a $74 \mu \mathrm{m}$ e geralmente predominam na faixa de 10 a $20 \mu \mathrm{m}$, mas como já mencionado as distintas técnicas usadas não permitem comparações efetivas. 


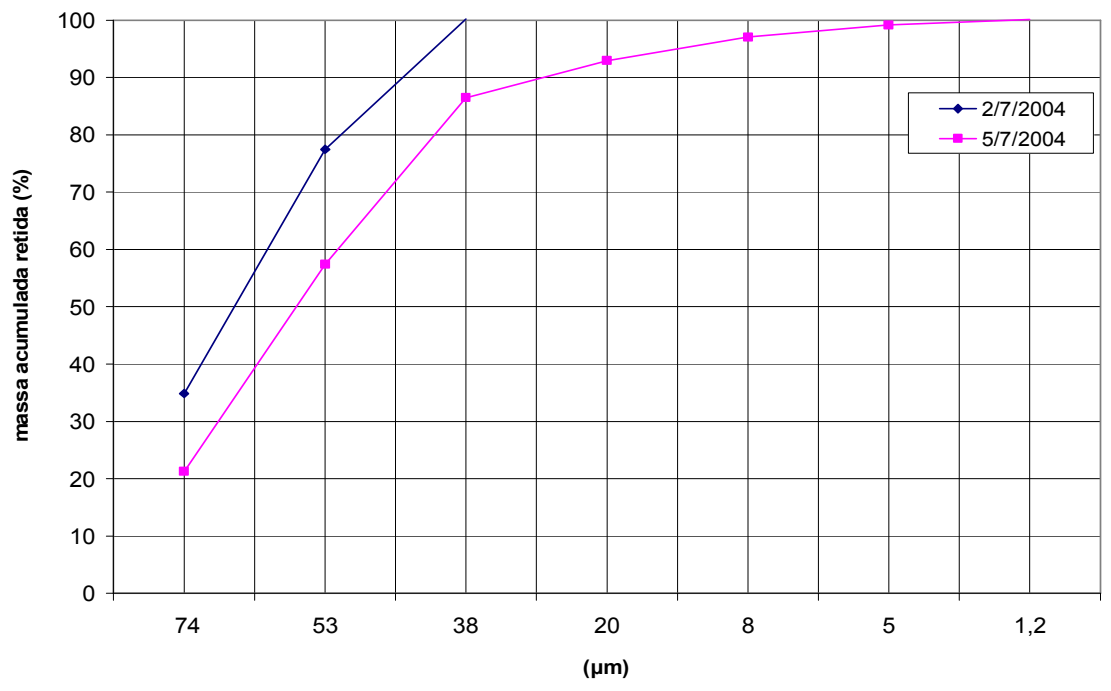

Figura 6.1 - Curva de porcentagem de massa de partículas retida X abertura de poro em $\mu \mathrm{m}$.

A mesma amostra do ensaio realizado no dia 02/07/2004 foi usada para a determinação de distribuição de tamanho de partículas por SEDIGRAPH. A Tabela 6.2 apresenta, comparativamente, os resultados de distribuição de tamanho de partículas entre as duas técnicas, fracionamento e SEDIGRAPH. Como pode ser observado, os resultados diferiram significativamente do ensaio de fracionamento.

Tabela 6.2 - Resultados de determinação de distribuição de tamanho de partículas por SEDIGRAPH e por fracionamento com múltiplas membranas.

\begin{tabular}{c|c|c|c}
\hline \multicolumn{2}{c|}{} & \multicolumn{2}{c}{ Fracionamento } \\
\cline { 3 - 4 } \multicolumn{2}{c}{ SEDIGRAPH } & Ensaio 1 $(2 / 7 / 2004)$ & Ensaio 2 $(5 / 7 / 2004)$ \\
\hline Diâmetro equivalente & $(\mu \mathrm{m})$ & $(\mu \mathrm{m})$ & $(\mu \mathrm{m})$ \\
\hline D $60<$ & 16 & 59,5 & 52 \\
\hline D $10<$ & 1,8 & - & - \\
\hline D $90<$ & 34 & 45 & 29 \\
\hline
\end{tabular}




\subsubsection{Estudo para determinação das frações de água e tratamento por congelamento de lodo}

Haja vista a ausência de resultados sobre a determinação das frações de água dos lodos de ETAs, apresentam-se os estudos e ensaios relativos ao desaguamento de lodo de ETA por congelamento (energia térmica).

A maioria dos métodos de desaguamento é limitada e somente remove água livre, ao contrário da técnica de congelamento que transforma as frações de água intersticial e vicinal na fração de água livre que pode ser removida mecanicamente/fisicamente. Pesquisadores russos (Zolotavin ${ }^{6}$ et al. 1960 apud Parker \& Collins, 1999) já citavam que o congelamento altera as propriedades de precipitados químicos.

Estudos desenvolvidos por Parker e Collins (1999), Martel et al. (1998), e Ormeci e Vesilind (2001) permitirem esclarecer os mecanismos que regem o congelamento do lodo e a partir da sua compreensão potencializaram seu uso como alternativa eficiente de desaguamento de lodos de ETAs, sem necessidade de adição de mais produtos químicos.

No congelamento, a água de ligação (fração de água vicinal e água de hidratação) é liberada pelo floco em que se encontrava previamente presa ou imobilizada, ou seja, a água por difusão pode migrar dos interstícios para a superfície enquanto os cristais de gelo são grandes e formados lentamente. Martel et al. (1998) esclarecem que os cristais de gelo são formados (incorporam) somente por moléculas de água, tanto que durante o crescimento dos cristais de gelo todas as outras moléculas, inclusive os flocos de lodos, são rejeitadas. Esses cristais de gelo não podem acomodar qualquer outro tipo de átomo ou molécula. Todo o tipo

\footnotetext{
${ }^{6}$ ZOLOTAVIN V. L., VOL'KHIN V. V. AND REZVUSHKIN V. V. (1960) Effect of freezing on the properties of coagulated metal hydroxides of coagulated ferric hydroxide. Part 1: Influence of freezing and thawing conditions on the properties of coagulated ferric hydroxide. Colloid Journal of the USSR 22(3), $317 \pm 324$.
} 
de partícula sólida é empurrado para a borda dos cristais, que os tornam comprimidos ou desidratados (Chalmers ${ }^{7}$ apud Ormeci e Vesilind 2001).

Parker \& Collins (1999), Martel et al. (1998) citam que fatores tais como concentração de sólidos, taxa de congelamento (velocidade de congelamento), temperatura final de congelamento, tempo de cura (tempo de permanência congelado) e características de composição de lodos de ETAs podem interferir na eficiência de conversão de água de ligação em água livre. A despeito dessas interferências realizaram-se ensaios para constatar o potencial uso de congelamento em lodos de ETAs como sistema de desaguamento.

Dessa forma, realizaram-se os ensaios de congelamento de lodo (uso de energia térmica) com posterior ensaio de sólidos sedimentáveis com amostras de lodo de decantador de ETA convencional de ciclo completo que usa sulfato de alumínio como coagulante.

Os resultados dos ensaios de congelamento, realizados em duplicata, com amostras de lodo com concentração de sólidos de aproximadamente 1,6\% são apresentados na Figura 6.2, construído a partir da Tabela A4, Anexo A. As amostras são descritas como lodo bruto 1 e 2 e lodos congelados 1 e 2 .

Após o congelamento, verificou-se que o lodo não consistia mais de uma suspensão de partículas finas, mas sim de uma mistura de cristais de gelo e finas partículas sólidas, como reportado em Martel et al. (1998). A razão é que quando os cristais se desfazem, as partículas permanecem consolidadas e não dissolvem mais. Essas partículas são grandes e facilmente sedimentáveis por gravidade (Figura 6.2).

\footnotetext{
${ }^{7}$ CHALMERS B. (1959). How water freezes. Sci. Am. 200, 114.
} 


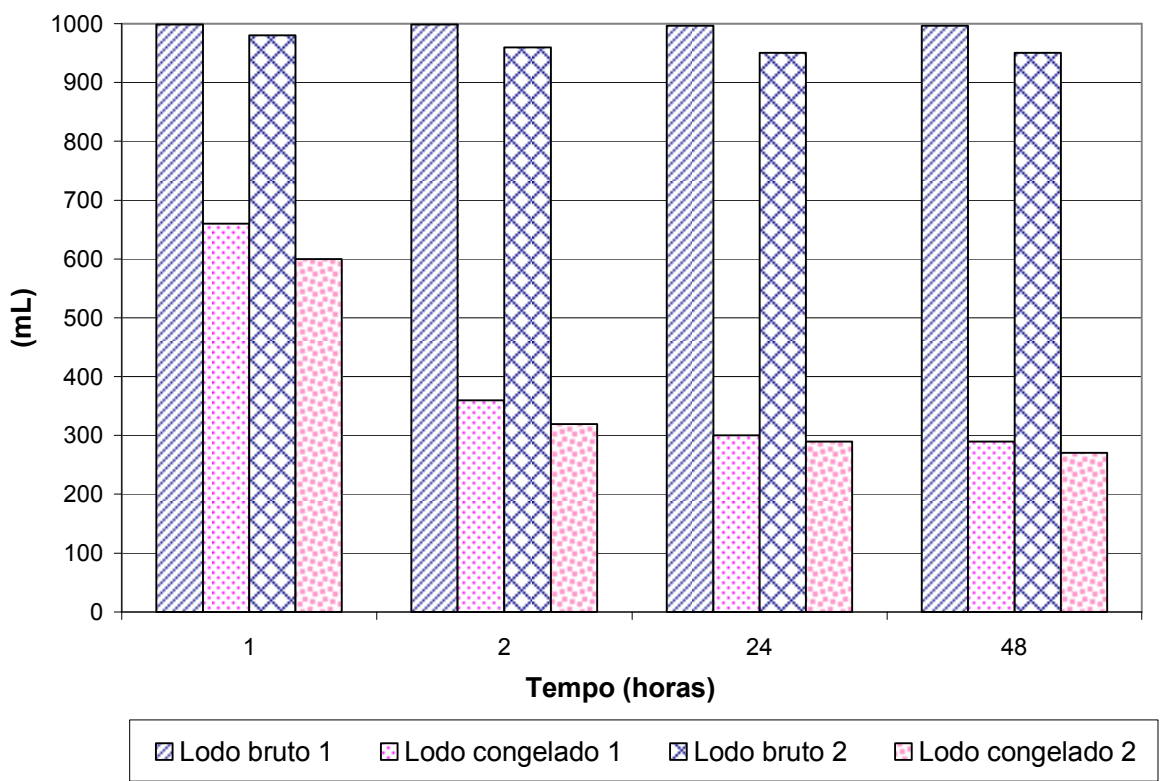

Figura 6.2 - Resultado de sólidos sedimentáveis nos tempos 1 hora, 2 horas, 24 horas e 48 horas para amostras "in natura" e após congelamento (descongelado) de lodo de ETA de sulfato de alumínio.

Dessa forma, o uso de energia térmica, na forma de congelamento e descongelamento, mostrou-se eficiente para o desaguamento de lodos de ETAs e apresentou partículas resultantes de fácil sedimentação e separação da fase líquida.

\subsubsection{Estudo de determinação de carbono orgânico total nas amostras de lodo de sulfato de alumínio e PACl}

O estudo consistiu em verificar o procedimento mais adequado de análise de amostras de lodo "in natura" quanto à determinação de carbono orgânico total. A intenção foi determinar o teor de carbono orgânico, presente nas frações líquidas e sólidas do lodo. Dessa forma, as análises tiveram como princípio promover a "queima" da matéria orgânica e conseqüente liberação de carbono orgânico na forma gasosa em recipiente fechado para posterior leitura da concentração de COT. 
Os testes de determinação de COT foram feitos com uso de analisador de COT, Euroglas e por cromatografia.

Para leitura no analisador de COT foram preparadas soluções estoques de carbono orgânico e inorgânico de aproximadamente $1 \mathrm{~g} / \mathrm{L}$, para a construção das curvas de calibração. As curvas de calibração foram construídas para as faixas de concentração de 50 a $500 \mathrm{mg} / \mathrm{L}$ de carbono e as leituras realizadas em duplicatas. Contudo, na realização das análises, inúmeros e sérios problemas de entupimento, diante da presença excessiva de sólidos, ocasionou grandes desvios dos valores de concentração de carbono para uma mesma amostra, além de causar danos ao equipamento. Apesar disso, obteve-se resultados de valores de concentração de COT, em torno de 5 a 9,6 g/L para amostras de lodo de sulfato de alumínio com teor de sólidos entre 1 e $2 \%$, conforme mostrado na Tabela 6.3.

Tabela 6.3 - Resultados dos valores de concentração de carbono orgânico total determinados pelo analisador de COT, nas amostras de lodos de sulfato de alumínio.

\begin{tabular}{c|c}
\hline Amostras & $\begin{array}{c}\text { Concentração de COT } \\
(\mathrm{g} \mathrm{C} / \mathrm{L})\end{array}$ \\
\hline 2LD & 8,7 \\
\hline 2LD1 & 5,3 \\
\hline 3LD & 11,3 \\
\hline 3LD1 & 10,9 \\
\hline 4LD & 12,2 \\
\hline 4LD1 & 7,6 \\
\hline 5LD & 11,8 \\
\hline 5LD1 & 7,1 \\
\hline
\end{tabular}

LD - Lodo de sulfato de alumínio (decantador)

Assim, verificou-se a possibilidade de leitura de COT por cromatografia. Nessa etapa foram realizadas três baterias de testes de análises.

As amostras preparadas em meio ácido foram congeladas em frascos calibrados, tampados com proteção de teflon e aquecidos em banho de glicerina por 2 horas a $150^{\circ} \mathrm{C}$. Resfriava-se e realizava-se a leitura de carbono no cromatográfo. As curvas foram construídas para as concentrações de 40, 80, 160, 240 e $320 \mathrm{mg} \mathrm{C/L}$. 
Na primeira bateria de análises, as amostras e brancos foram preparadas em solução ácida de 3,5 mL de $\mathrm{H}_{2} \mathrm{SO}_{4}$ mais $\mathrm{K}_{2} \mathrm{Cr}_{2} \mathrm{O}_{7}$ e congeladas. Porém, ao levar ao banho quente de glicerina, as amostras reagiram com o material dos frascos (tampas manchadas) e os valores de carbono orgânico e inorgânico da curva de calibração e das amostras foram incoerentes.

Na segunda bateria de análises, as amostras foram preparadas em meio ácido somente com $\mathrm{H}_{2} \mathrm{SO}_{4}$, congeladas e aquecidas com posterior leitura de carbono inorgânico. $\mathrm{O}$ carbono orgânico total foi determinado com adição de persulfato $\left(1,0 \mathrm{~mL}\right.$ de $\mathrm{H}_{2} \mathrm{SO}_{4} ; 1,0 \mathrm{~mL}$ de amostra/água destilada; 4,0 $\mathrm{mL}$ de persulfato). Dessa vez, as concentrações de carbono orgânico mostraram-se elevadas e muito próximas do carbono inorgânico, com ocorrência de picos não identificados nas respostas gerados no cromatográfo, comprometendo os resultados.

Na terceira bateria de análises, as curvas de calibração foram construídas com adição de persulfato e ftalato em meio ácido $\left(2,5 \mathrm{~mL}\right.$ de $\mathrm{H}_{2} \mathrm{SO}_{4}$ a $30 \% ; 2,5 \mathrm{~mL}$ de persulfato a $20 \%$; $1,0 \mathrm{~mL}$ de padrão/ftalato). De maneira promover a seguinte reação.

$\mathrm{C}_{8} \mathrm{H}_{6} \mathrm{O}_{4}+15 \mathrm{~K}_{2} \mathrm{~S}_{2} \mathrm{O}_{8}+12 \mathrm{H}_{2} \mathrm{O} \rightarrow 8 \mathrm{CO}_{2}+30 \mathrm{KHSO}_{4}$

Porém, a curva de calibração obtida não apresentou resultados satisfatórios com presença de desvios.

Novamente foram construídas curvas com adição de persulfato em meio ácido, $\left(\mathrm{H}_{2} \mathrm{SO}_{4}\right.$ a 30 \%). As amostras foram preparadas em meio ácido e persulfato, e com adição de ftalato para leitura de carbono orgânico. Dessa vez, a curva de leitura, bem como, os valores de carbono orgânico determinados de amostras de lodos apresentaram resultados satisfatórios, porém determinadas amostras dos lodos de sulfato de alumínio e de $\mathrm{PACl}$ apresentaram interferências, não sendo possível elucidar tais problemas na presente pesquisa. 


\subsubsection{Ensaios preliminares para definição dos procedimentos operacionais necessários e} definição das variáveis de controle

Nesta etapa realizaram-se diversos ensaios com lodo de sulfato de alumínio obtido, por coleta simples, da ETA A.

Verificou-se a necessidade de auxílio de mais uma ou duas pessoas para auxiliar nos procedimentos de lançamento do lodo, coleta de amostras, registro do tempo, determinação de vazão de drenagem e leitura de determinadas características do drenado, como turbidez, cor, pH e série de sólidos.

Posto isso, apresentam-se os resultados de ensaios preliminares para verificar a necessidade de condicionamento químico das amostras de lodos a serem desaguados. Nesse estudo teve como pressuposto básico usar o mínimo de consumo de energia e produtos químicos.

$\mathrm{Na}$ seqüência são apresentados os resultados dos ensaios preliminares de desaguamento por leito de drenagem para definição das variáveis de controle e procedimentos operacionais.

\subsubsection{Ensaios preliminares: necessidade e influência de condicionamento.}

Ensaios preliminares foram realizados com intuito de verificar a necessidade e influência de condicionamento no desaguamento por leito de drenagem. Para sistemas mecânicos verifica-se que o condicionamento exerce grande influência no desempenho do desaguamento, conforme reporta inúmeros pesquisadores ASCE e AWWA (1996); Dentel (1997); Archimedes (2003).

A Figura 6.3 (a) e (b) mostra a variação da vazão de drenagem e a variação da concentração de sólidos na fase de secagem para as amostras de lodos com e sem polímero. A Figura 6. 4 mostra a curva de sedimentação obtida no ensaio de coluna de sedimentação 


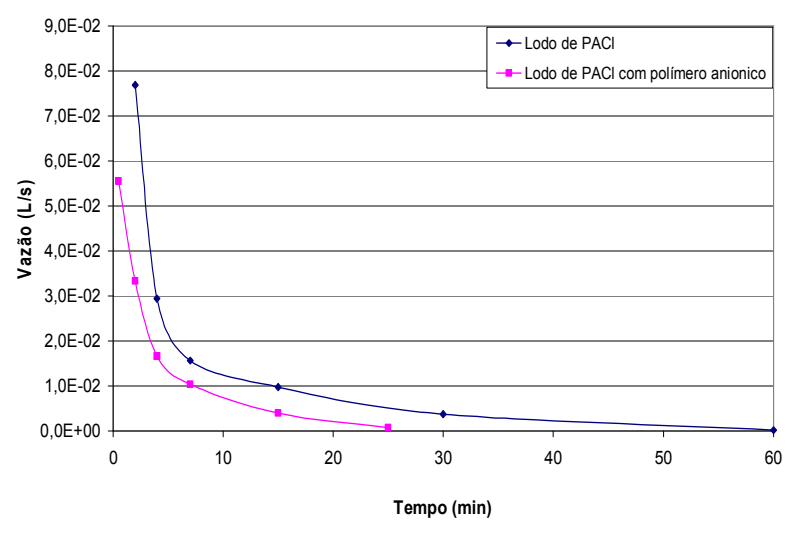

(a)

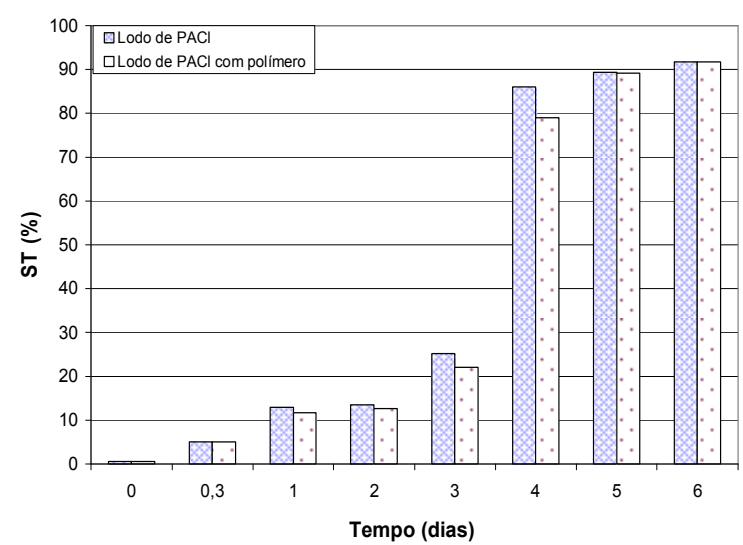

(b)

Figura 6.3 - Variação da vazão de drenagem para lodo de $\mathbf{P A C} \boldsymbol{\ell}$ com e sem condicionamento químico (a) e variação do teor de sólidos ST (\%) do resíduo de $\mathbf{P A C} \boldsymbol{\ell}$ retido na manta do leito de drenagem (b).

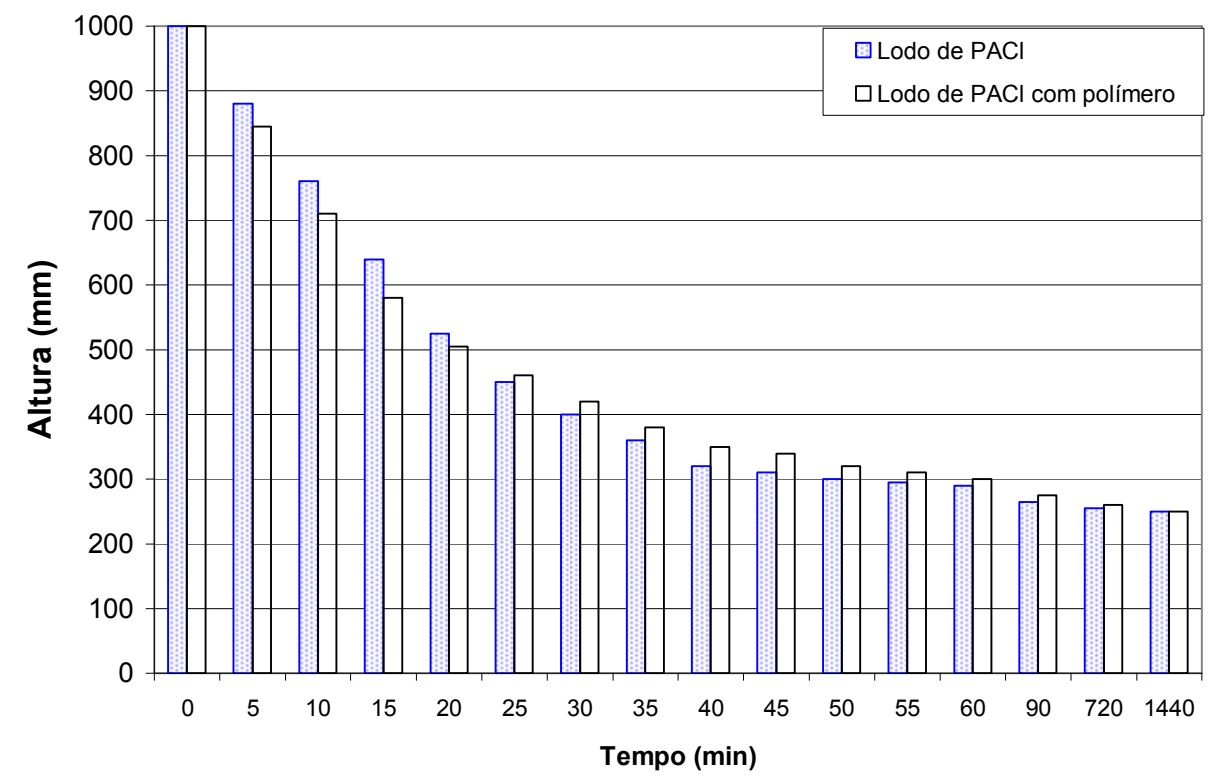

Figura 6.4 - Curva de sedimentação das amostras de lodos de PACl com e sem adição de polímero aniônico de elevada massa molecular $($ dosagem $=1 \mathrm{~g} / \mathrm{kg} \mathrm{SST})$.

A Figura 6.5 ilustra a execução dos ensaios testes realizados no protótipo de leito de drenagem (II) e ensaio definitivo realizado no Leito de Drenagem (I). 


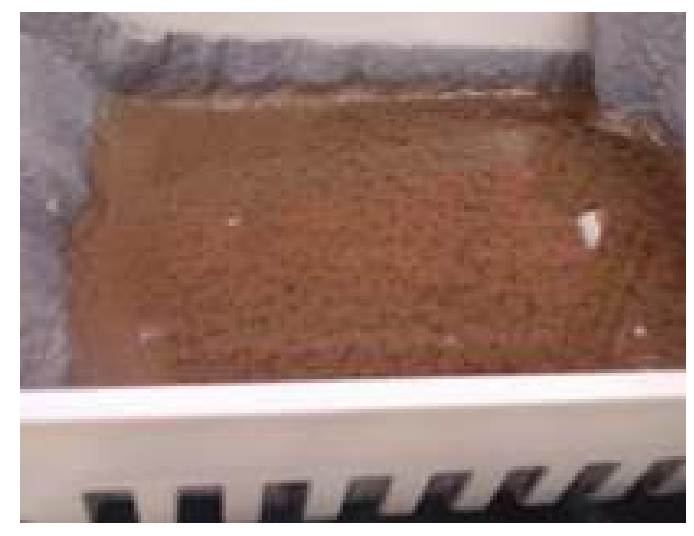

(a)

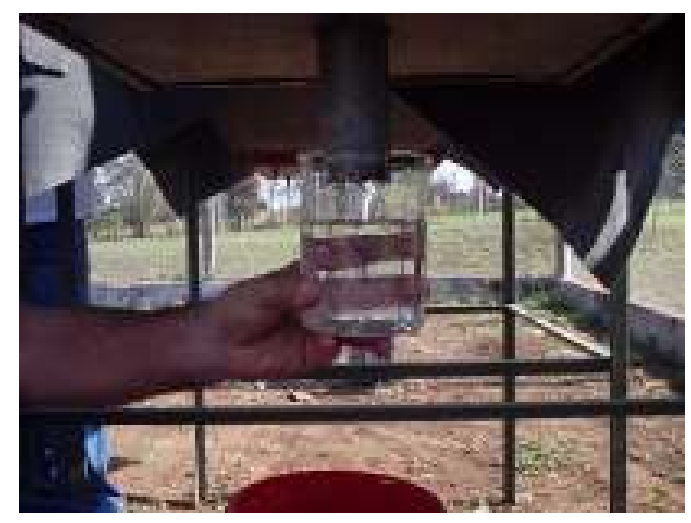

(c)

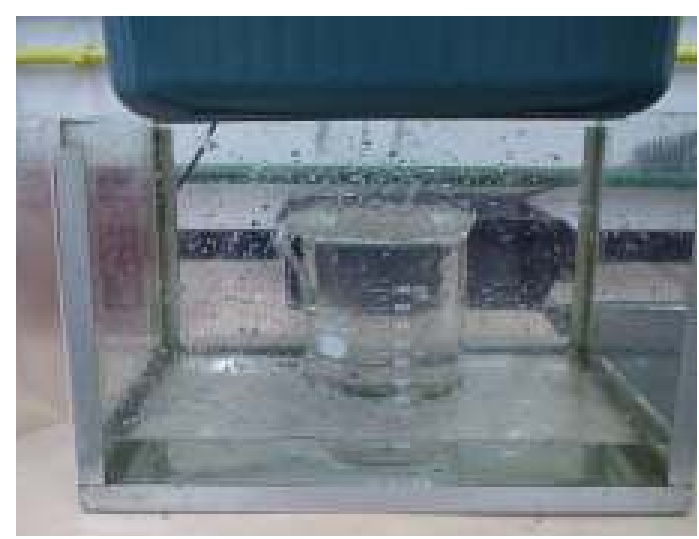

(b)

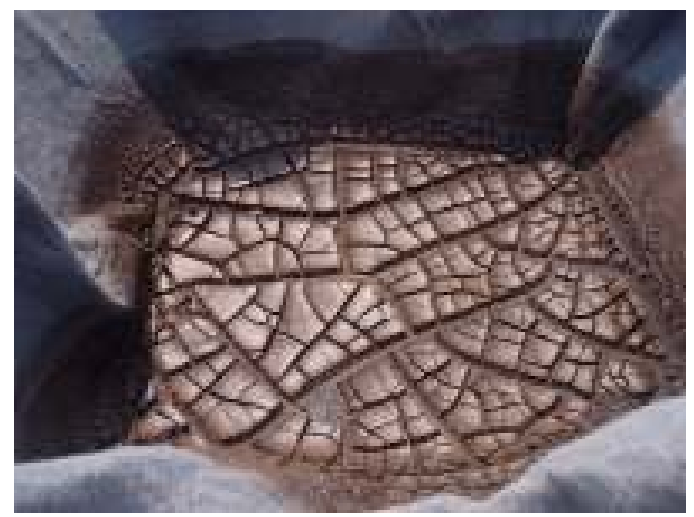

(d)

Figura 6.5 - Fotografias dos ensaios de desaguamento de lodo de PACl com adição de polímero aniônico de elevada massa molecular ( $1 \mathrm{~g} / \mathrm{kg}$ SST) por Leito de Drenagem. (a) lodo de PACl com polímero aplicado no Leito de Drenagem II. (b) vista da água livre drenada obtida no ensaio preliminar no protótipo de Leito de Drenagem II. (c) vista da água livre drenada do lodo de $\mathrm{PACl}$ com adição de polímero desaguado por Leito de Drenagem I. (d) massa de lodo retida no Leito de Drenagem I.

A partir da Figura 6.5 pode-se constatar a boa qualidade da água livre drenada. $\mathrm{Na}$ Figura 6.6 apresentam-se os resultados dos valores de turbidez da água livre drenada das amostras de lodo de $\mathrm{PACl}$ sem e com adição de polímero. 


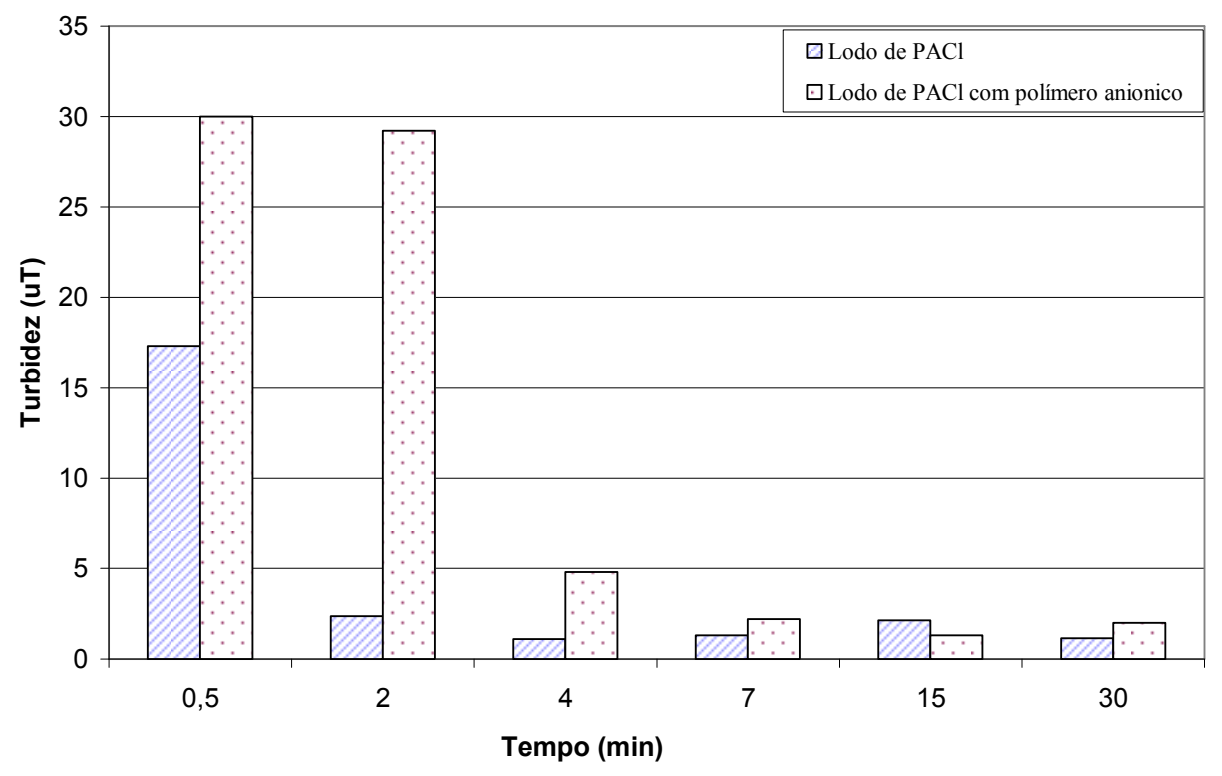

Figura 6.6 - Valores de turbidez da água livre drenada das amostras de lodo de PAC $\ell$ com e sem adição de polímero.

Os resultados apresentados nas Figuras 6.3 e 6.4 não evidenciaram grande influência nas características e desempenho no desaguamento por leito de drenagem. De acordo com a Figura 6.6, o drenado de lodo com polímero apresentou no início do ensaio, valores de turbidez ligeiramente superiores ao drenado de lodo sem polímero. Contudo, os valores máximos de turbidez estão abaixo de $35 \mathrm{uT}$.

\subsubsection{Ensaios preliminares: Definição das variáveis de controle e procedimentos operacionais.}

Na seção 6.1.2.2 são apresentados os resultados dos ensaios que fundamentaram a definição das variáveis de controle e procedimentos operacionais usados na Fase 02.

Inicialmente foram realizados ensaios nos protótipos de Leito de Drenagem I, inclusive com a verificação da colocação da manta em cortes (cruz de malta), visto o formato tronco de pirâmide do equipamento. Posteriormente verificou-se a possibilidade de realização de ensaios com uso de protótipos de leito de drenagem em acrílico, Leito de Drenagem III. 
Os resultados quanto ao estudo da configuração do leito de drenagem, colocação e disposição das mantas geotêxteis são relatados, a seguir.

Para os protótipos de Leito de Drenagem I, a colocação das mantas em segmentos com emendas (cruz de malta) mostrou-se ineficaz. Nas emendas foram testadas fitas adesivas, grampos, cola de sapateiro, cola industrial e praticamente em todos houve vazamento de lodo, comprometendo a qualidade da água drenada. Assim, a adoção de uso da manta sem emendas mostrou-se mais eficiente e vantajosa.

Nos protótipos de Leito de Drenagem III em acrílico, os constantes vazamentos pelas emendas mostraram-se problemático. Além disso, o pequeno diâmetro (tamanho) do protótipo impossibilitava o uso de mantas sem emendas. Portanto, optou-se em descartar o seu uso nos ensaios definitivos constantes da Fase 02 e adotar o Leito de Drenagem II.

Assim, a configuração definitiva dos Leitos de Drenagem I e II usados nos ensaios de desaguamento da Fase 02 resultou em uma camada de cinco centímetros de brita 01 mais uma camada de manta geotêxtil conforme especificações citadas no Capítulo 5, seção 5.3.

No tocante ao estudo, de fato, dos procedimentos dos ensaios de desaguamento e das variáveis de controle, os resultados dos ensaios preliminares confirmaram a ocorrência do desaguamento em duas fases distintas, Fase de drenagem e Fase de secagem.

Nas Tabelas 6.4, 6.5 e 6.6 apresentam-se os resultados de três ensaios de desaguamento por leito de drenagem, realizados com amostras de lodos de sulfato de alumínio, para verificar os procedimentos de medição de vazão e conseqüente determinação da variação da vazão de drenagem. O volume aplicado e a concentração inicial de sólidos das amostras de lodo usado nos ensaios com uso do Leito de Drenagem I foram de 15 litros e ST $(\%)=7,6 \%$ para o primeiro ensaio (Ensaio I), segundo ensaio (Ensaio II) de 15 litros e ST $(\%)=2,2 \%$ e para o terceiro ensaio (Ensaio III) realizado no Leito de Drenagem III em acrílicos, volume de 3,5 L e ST $(\%)=2,2 \%$. 
Tabela 6.4 - Resultados do ensaio de desaguamento com amostra de lodo de sulfato de alumínio (ST=7,6 \%) no Leito de Drenagem I.

\begin{tabular}{c|c|c|c}
\hline Ensaios & $\begin{array}{c}\text { Volume de aplicação } \\
(\mathrm{L})\end{array}$ & $\begin{array}{c}\text { Duração de ensaio } \\
\text { (minutos) }\end{array}$ & $\begin{array}{c}\text { Vazão de drenagem } \\
\text { média } \\
(\mathrm{L} / \mathrm{s})\end{array}$ \\
\hline $\mathbf{I}$ & 15 & 120 & 0,125 \\
\hline
\end{tabular}

Tabela 6.5 - Resultados do Ensaio II de desaguamento com amostra de lodo de sulfato de alumínio ( $\mathrm{ST}=2,2 \%$ ) e volume aplicado de 15 litros, Leito de Drenagem I.

\begin{tabular}{c|c|c|c}
\hline $\begin{array}{c}\text { Tempo } \\
(\text { minutos })\end{array}$ & $\begin{array}{c}\text { Vazão de drenagem } \\
(\mathrm{L} / \mathrm{s})\end{array}$ & $\begin{array}{c}\text { Redução de volume } \\
(\%)\end{array}$ & $\begin{array}{c}\text { Altura da massa de } \\
\text { lodo } \\
(\mathrm{cm})\end{array}$ \\
\hline 0 & 0,0000 & 0,0 & 8,00 \\
\hline 5 & 0,1080 & 3,4 & 7,50 \\
\hline 10 & 0,0340 & 5,5 & 7,00 \\
\hline 15 & 0,0200 & 7,4 & 6,80 \\
\hline 30 & 0,0080 & 8,9 & 6,60 \\
\hline 45 & 0,0044 & 10,1 & 6,00 \\
\hline 60 & 0,0027 & 11,1 & 5,80 \\
\hline
\end{tabular}

Tabela 6.6 - Resultados do Ensaio III de desaguamento com amostra de lodo de sulfato de alumínio (ST=2,2 \%) e volume aplicado de 3,5 litros no Leito de Drenagem III.

\begin{tabular}{c|c|c|c}
\hline $\begin{array}{c}\text { Tempo } \\
(\text { minutos })\end{array}$ & $\begin{array}{c}\text { Vazão de drenagem } \\
(\mathrm{L} / \mathrm{s})\end{array}$ & $\begin{array}{c}\text { Redução de volume } \\
(\%)\end{array}$ & $\begin{array}{c}\text { Altura da massa de } \\
\text { lodo } \\
(\mathrm{cm})\end{array}$ \\
\hline 2 & $2,0 \times 10^{3}$ & 18,3 & 15 \\
\hline 5 & $8,9 \times 10^{4}$ & 29,1 & 11,5 \\
\hline 20 & $4,5 \times 10^{4}$ & 48,9 & 9 \\
\hline 40 & $1,9 \times 10^{4}$ & 58,9 & 5 \\
\hline 60 & $2,0 \times 10^{4}$ & 67,1 & 4 \\
\hline 90 & $1,0 \times 10^{4}$ & 74,3 & 3,2 \\
\hline 120 & $7,8 \times 10^{5}$ & 77,1 & 3 \\
\hline 180 & - & 78,6 & \\
\hline
\end{tabular}

A Figura 6.7 representa, graficamente, a variação da vazão de água livre drenada nos Ensaios II e III, construída a partir das Tabelas 6.5 e 6.6. Ressalta-se que a fase de drenagem não encerrou no tempo 60 minutos.

Para os Ensaios II e III de desaguamento de lodo gerado em ETA que usa sulfato de alumínio, a drenagem de água livre teve duração máxima de aproximadamente 6 horas. $\mathrm{O}$ tempo total da fase de drenagem foi registrado para quando houve cessão total de drenagem 
da água livre ou apresentassem valores de vazão de drenagem menores que $\mathrm{Q}=1,67 \times 10^{-3}$ $\mathrm{L} / \mathrm{min}$ ou $2,80 \times 10^{-5} \mathrm{~L} / \mathrm{s}$, equivalente a $25 \mathrm{~mL}$ no intervalo de $15 \mathrm{~min}$.

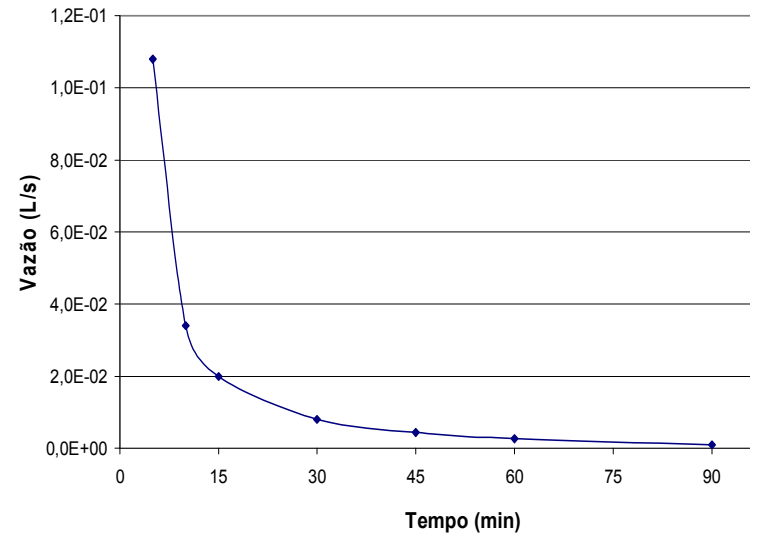

(a)

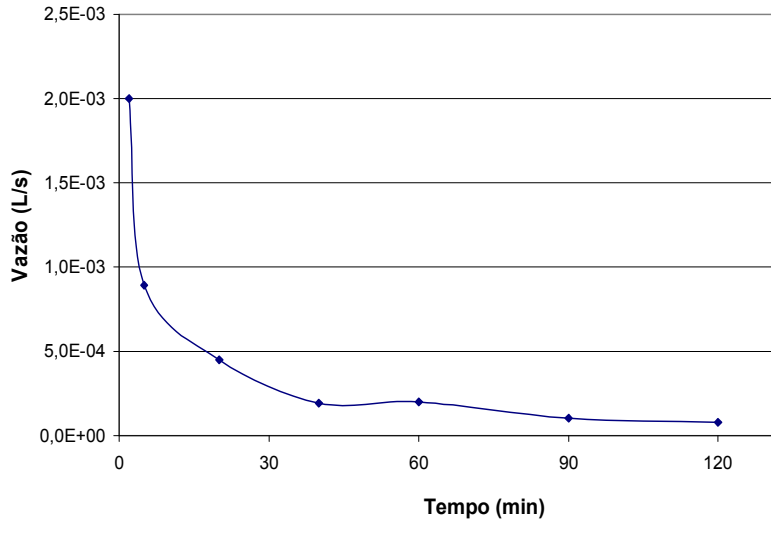

(b)

Figura 6.7 - Variação da vazão de drenagem de água livre resultante de ensaio de desaguamento no Leito de Drenagem I em 20/05/2004 (a) e de ensaio realizado no Leito de Drenagem III em acrílico (b) com amostras de lodo de sulfato de alumínio.

O uso do Leito de Drenagem III na Fase 02 foi descartado. A execução dos ensaios preliminares na Fase 01 com uso dos Leitos de Drenagem III evidenciou inúmeras desvantagens, tais como o vazamento de amostras de lodo através das emendas das mantas e impossibilidade de avaliar a ação das variáveis climáticas, diante da constatação de formação de áreas desiguais de umidades devido à existência de regiões sombreadas.

A duração da Fase de Secagem, bem como do ensaio de desaguamento foi definido para o período máximo de 7 dias após a aplicação de lodo ou quando houvesse impossibilidade de coleta de partículas ou sólidos do lodo desaguado retido na manta.

Assim, a execução dos ensaios I, II e III permitiu definir os procedimentos operacionais a serem usados na Fase 02, conforme reportado no Capítulo 5, seção 5.4. 


\subsection{Fase 02: Ensaios de desaguamento com lodo de sulfato de alumínio e de cloreto de polialuminio (PAC $\ell$ ) por leito de drenagem}

Na seção 6.2 são apresentados os resultados de cada ensaio no total de 6 ensaios com aplicação de 11 amostras.

Os lodos utilizados nos ensaios foram coletados de duas ETAs convencionais de ciclo completo, ETA B e C, as quais apresentam as seguintes características:

Lodo proveniente de coagulante Sulfato de Alumínio: estação de tratamento de água com as etapas de coagulação, floculação, decantação convencional e filtração. Apresenta adição de cal após a coagulação.

Lodo proveniente de coagulante Cloreto de Polialumínio (PAC $)$ : estação de tratamento de água com as etapas de pré-oxidação (cloro), coagulação, adição de carvão ativado, floculação, decantação convencional e filtração.

O volume e teor de sólidos inicial das amostras de lodos aplicadas em cada ensaio são mostrados na Tabela 6.7.

A apresentação e discussão dos resultados para cada ensaio foram subdividas em: caracterização das amostras de lodos aplicadas e variáveis relacionadas com os ensaios de desaguamento de Leito de Drenagem, quanto à Fase de Drenagem e à Fase de Secagem.

A avaliação quanto a influência das variáveis climáticas na Fase de Secagem estão apresentadas na seção 6.3 em que realiza-se a avaliação conjunta dos ensaios de desaguamento. 
Tabela 6.7 - Realização de coleta e aplicaçde amostras para estudo das características e de desaguamento por leito de drenagem.

\begin{tabular}{|c|c|c|c|c|}
\hline Ensaio & $\begin{array}{l}\text { Lodo - tipo de } \\
\text { coagulante }\end{array}$ & $\begin{array}{c}\text { Volume } \\
\text { (L) }\end{array}$ & $\begin{array}{c}\text { Altura inicial da } \\
\text { camada de lodo (cm) }\end{array}$ & $\begin{array}{l}\text { Teor de sólidos inicial } \\
\qquad \mathbf{S T}_{\mathbf{0}}(\%)\end{array}$ \\
\hline \multirow{2}{*}{1} & Sulfato de alumínio & 25 & 11 & 2,60 \\
\hline & $\begin{array}{c}\text { Cloreto de } \\
\text { polialumínio }\end{array}$ & 25 & 11 & 1,40 \\
\hline 2 & $\begin{array}{c}\text { Cloreto de } \\
\text { polialumínio }\end{array}$ & 20 & 10 & 0,22 \\
\hline \multirow[b]{2}{*}{3} & Sulfato de alumínio & 8 & 13 & 7,6 \\
\hline & $\begin{array}{l}\text { Cloreto de } \\
\text { polialumínio }\end{array}$ & 8 & 13 & 0,04 \\
\hline \multirow[b]{2}{*}{4} & Sulfato de alumínio & 55 & 20 & 0,76 \\
\hline & $\begin{array}{c}\text { Cloreto de } \\
\text { polialumínio }\end{array}$ & 55 & 20 & 0,26 \\
\hline \multirow[b]{2}{*}{$5^{a}$} & Sulfato de alumínio & 8 & 13 & 2,7 \\
\hline & $\begin{array}{c}\text { Cloreto de } \\
\text { polialumínio }\end{array}$ & 8 & 13 & 0,28 \\
\hline \multirow[b]{2}{*}{$5 B$} & Sulfato de alumínio & 8 & 13 & 4,2 \\
\hline & $\begin{array}{c}\text { Cloreto de } \\
\text { polialumínio }\end{array}$ & 8 & 13 & 0,26 \\
\hline
\end{tabular}

\subsubsection{Ensaio 1}

No Ensaio 1 foi aplicado $25 \mathrm{~L}$ de amostras de lodo de sulfato de alumínio e de lodo de PACl. As características gerais são apresentadas na Tabela 6.8 .

Tabela 6.8 - Caracterização dos resíduos utilizados nos ensaios de desaguamento por leito de drenagem.

\begin{tabular}{|c|c|c|c|c|}
\hline \multirow[t]{2}{*}{ Amostras de lodo } & \multirow[t]{2}{*}{$\mathrm{ST}_{\mathbf{0}}(\%)$} & \multirow{2}{*}{$\begin{array}{c}\text { TAS } \\
\left(\mathrm{kg} / \mathrm{m}^{2}\right)\end{array}$} & \multicolumn{2}{|c|}{ Sólidos Sedimentáveis $(\mathrm{mL} / \mathrm{L})$} \\
\hline & & & $1 \mathrm{~h}$ & $2 \mathrm{~h}$ \\
\hline Sulfato de alumínio & 2,6 & 3,43 & 550 & 470 \\
\hline $\mathrm{PACl}$ & 1,4 & 1,86 & 470 & 450 \\
\hline
\end{tabular}

A Figura 6.8 representa graficamente os resultados dos ensaios de coluna de sedimentação realizados com as amostras de lodo de sulfato de alumínio e de PACl. O gráfico foi construído a partir dos resultados constantes na Tabela A5, Anexo A. 


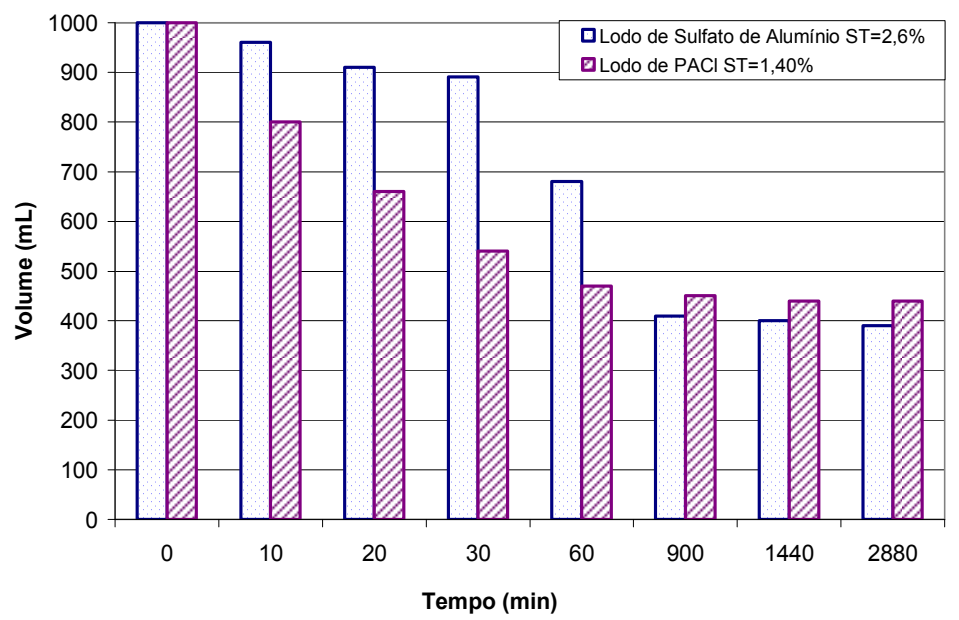

Figura 6.8 - Curva de sedimentação dos lodos de sulfato de alumínio e PACl.

No Ensaio 1, a velocidade de sedimentação máxima foi de $\mathbf{V s}=\mathbf{0 , 2 1} \mathbf{c m} / \mathbf{m i n}$ até 30 minutos para o lodo de sulfato de alumínio e de $\mathbf{V s}=\mathbf{0 , 7 8} \mathbf{~ c m} / \mathbf{m i n}$, para lodo de $\mathrm{PACl}$.

Para $\mathrm{t}=60$ minutos, a coluna de sedimentação indicava $680 \mathrm{~mL}$ para amostra de lodo de sulfato de alumínio e $470 \mathrm{~mL}$ para a amostra de lodo de PACl. Porém, após 900 minutos ocorreu inversão de tendência, lodo de sulfato de alumínio $=400 \mathrm{~mL}$ e lodo de $\mathrm{PAC} \ell=450$ mL. Assim, verificou-se que o lodo de PAC $\ell$ apresentou maior sedimentabilidade até 1 hora. Porém, após 24 horas o lodo proveniente de sulfato de alumínio suplantou ao PACl.

\subsubsection{Aplicação e Desaguamento dos lodos nos Leitos de Drenagem - Fase de Drenagem}

As amostras de lodo de sulfato de alumínio e de PACl foram aplicados nos Leitos de Drenagem I. A variação de vazão da água drenada é apresentado na Figura 6.9.

A vazão de drenagem inicial foi de $\mathrm{Q}=0,33 \mathrm{~L} / \mathrm{min}$ para lodo de sulfato de alumínio (TAS de 3,46 kg/m²) e, Q = 1,22 L/min, para lodo de PACl (TAS de $1,86 \mathrm{~kg} / \mathrm{m}^{2}$ ), conforme pode ser observado na Figura 6.9. 
A vazão de drenagem do lodo de $\mathrm{PACl}$ apresentou-se mais elevada que para sulfato de alumínio, tendência esta apresentada até o final da fase de drenagem. O tempo de drenagem para o lodo de sulfato de alumínio foi $T d=300 \mathrm{~min}$ e para o lodo de $\mathrm{PAC}, \mathrm{Td}=60 \mathrm{~min}$.

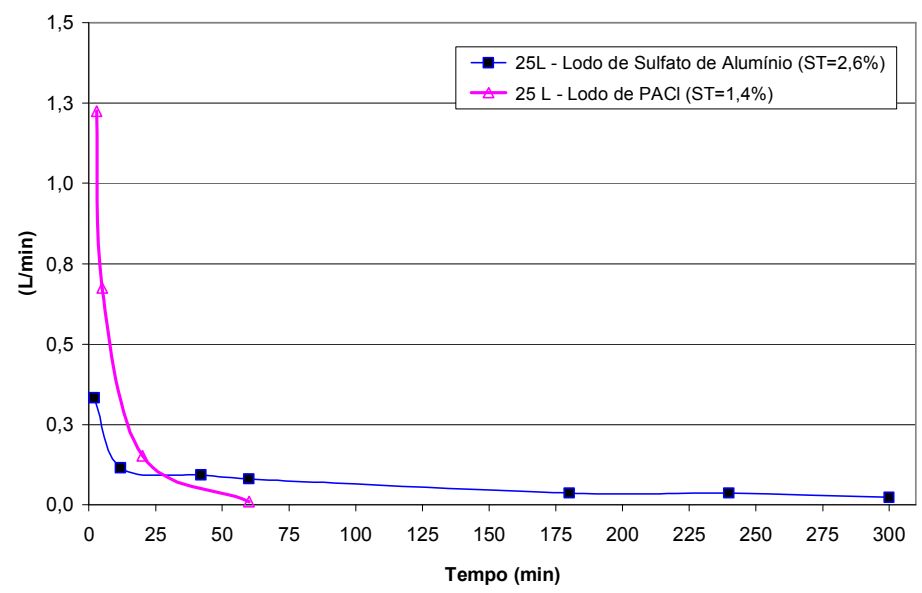

Figura 6.9 - Variação da vazão de drenagem da água livre (em L/min) para os lodos de sulfato de alumínio e $\mathrm{PACl}$ durante as primeiras 5 horas.

Após o término da fase de drenagem ocorreu precipitação (chuva), que provocou novo incremento de vazão de drenagem da água livre conforme observado na Figura 6.10.

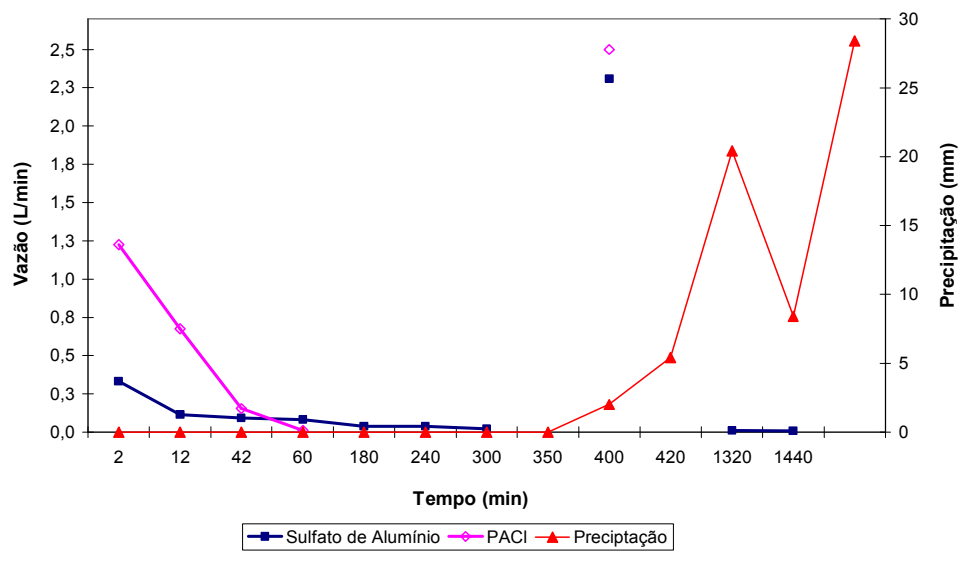

Figura 6.10 - Influência da chuva na vazão de drenagem da água livre (em L/s) para os lodos de sulfato de alumínio e $\mathrm{PAC} \ell$ durante as primeiras 24 horas.

Nota-se pela Figura 6.10 que após ocorrência de chuva (precipitação), houve aumento considerável na vazão de drenagem, ou seja, a água de chuva não se incorporou à massa de lodo, não ficou retida no leito e drenou imediatamente com vazão de $2,5 \mathrm{~L} / \mathrm{min}$ para o lodo de $\mathrm{PACl}$ e $2,3 \mathrm{~L} / \mathrm{min}$ para o lodo de sulfato de alumínio. 
A Figura 6.11 apresenta a variação percentual do volume acumulado de água livre drenada. Os valores absolutos de volume acumulado, bem como valor percentual são apresentados na Tabela A6, Anexo A.

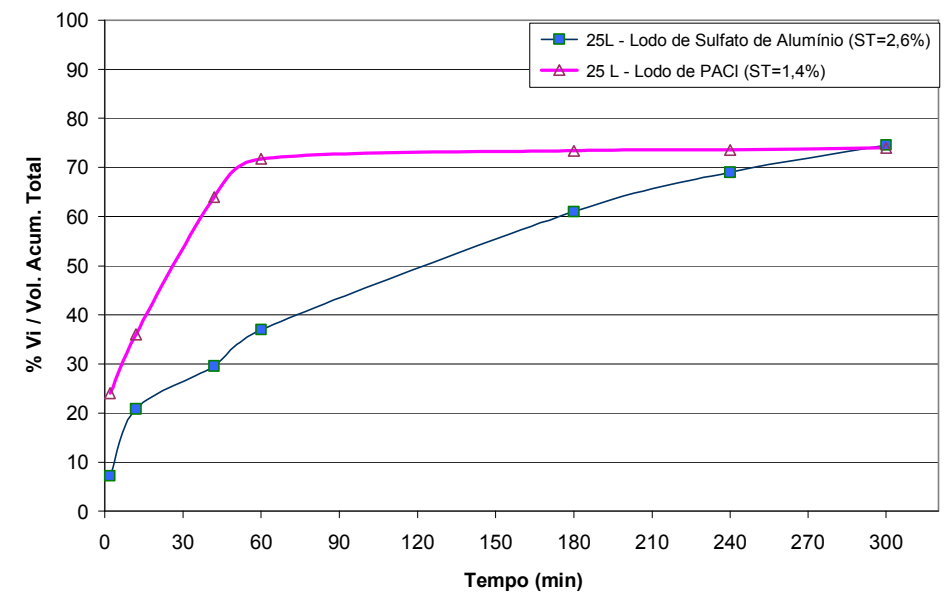

Figura 6.11 - Volume acumulado de drenagem da água livre em (\%) para os lodos de sulfato de alumínio e PACl.

A drenagem de água livre para o $\mathrm{PACl}$ encerrou aproximadamente após 1 hora (60 min), e deu inicio a aberturas na massa do lodo e à secagem por evaporação. O volume acumulado coletado a partir da drenagem da água livre foi de aproximadamente $18 \mathrm{~L}$ ou cerca de $74 \%$ do volume de amostra aplicada. Entretanto, para o lodo de sulfato de alumínio a drenagem de água livre prosseguiu por 5 horas (300 min), quando só então atingiu o volume acumulado de $18 \mathrm{~L}$.

Para avaliar o desempenho e a viabilidade do desaguamento foram construídos gráficos que apresentam conjutamente a variação de volume acumulado e os valores de turbidez, conforme apresentado na Figura 6.12 (a) e (b).

Na Figura 6.12 (a) observa-se que para o lodo de sulfato de alumínio o volume de lodo aplicado, cerca de $20,8 \%$ foi drenado na forma de água livre no tempo de 12 minutos, com valores de turbidez acima de 40 uT. Não houve leitura de turbidez no tempo de 42 minutos, mas extrapolando a tendência da curva obtida pode-se esperar que valor de turbidez menor 
que 20 uT foi obtido entre 42 e 60 minutos, correspondente aos volumes acumulados de 29,6 e $37,0 \%$ respectivamente.

Para o lodo de $\mathrm{PACl}$, a água drenada apresentou valor inicial de turbidez de aproximadamente $30 \mathrm{uT}$, para um volume acumulado de $24 \%$ em 3 minutos. Após 5 minutos e volume acumulado de $36 \%$, a água drenada apresentou valor de turbidez próximos de 2,0 uT.

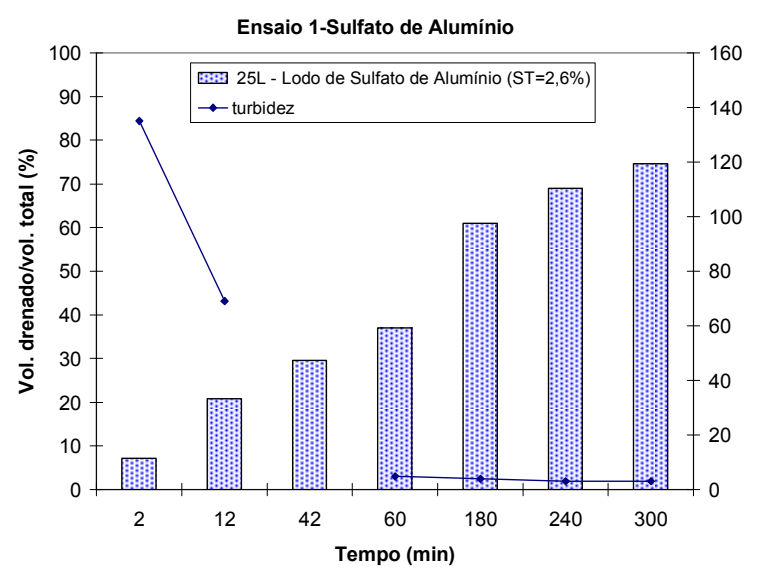

(a)

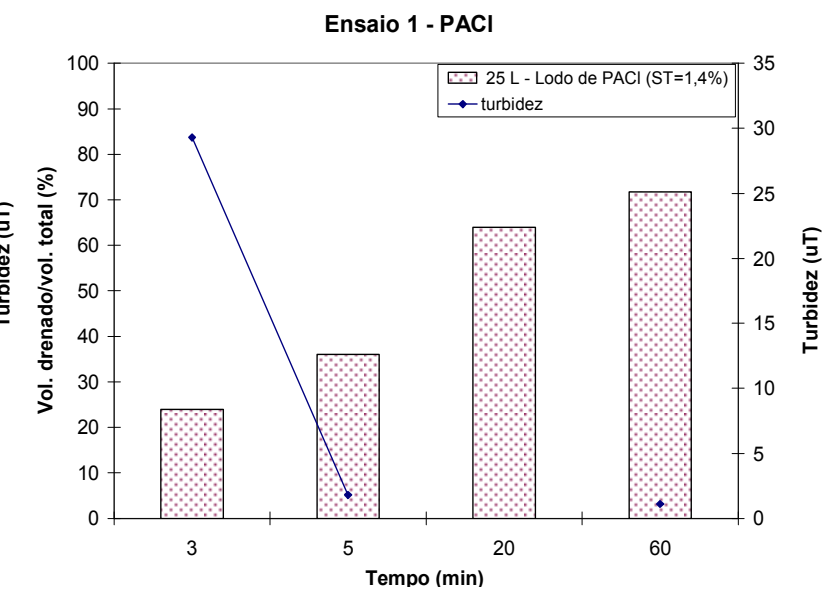

(b)

Figura 6.12 - Variação dos valores de volume acumulado de água livre drenada em (\%) e de turbidez durante a fase de drenagem, para as amostras de lodos de sulfato de alumínio (a) e de lodos de PACl (b).

\subsubsection{Desaguamento dos lodos nos Leitos de Drenagem - Fase de Secagem}

Na Tabela 6.9 é apresentada a variação diária de teor de sólidos nos lodos desaguados e retidos na manta geotextil. O teor de sólidos totais obtido após 24 horas foi aproximadamente de 13\% para o lodo de sulfato de alumínio e 9\% para o lodo de PACl. Após sete dias, estes teores foram de $31 \%$ e $28,4 \%$ respectivamente. 
Tabela 6.9 - Variação da concentração de sólidos para o resíduo retido no leito de drenagem.

\begin{tabular}{|c|c|c|}
\hline \multirow{3}{*}{ Tempo (dias) } & \multicolumn{2}{|c|}{ Variação de teor de sólidos } \\
\hline & \multicolumn{2}{|c|}{ ST $(\%)$} \\
\hline & Sulfato de alumínio & PACl \\
\hline 0 & 2,6 & 1,4 \\
\hline 1dias & 13 & 8,8 \\
\hline 2 dias & 16 & 11,1 \\
\hline 3 dias & 17 & 11,9 \\
\hline 4 dias & 23 & 22,7 \\
\hline 5 dias & 22 & 19,0 \\
\hline 6 dias & 24 & 20,6 \\
\hline 7 dias & 31 & 28,4 \\
\hline 21 dias & 80 & 88,0 \\
\hline
\end{tabular}

A seqüência de fotografias da Figura 6.13 ilustra a evolução do desaguamento para os lodos de PACl e Sulfato de Alumínio, durante os sete dias de ensaio. Nota-se considerável redução de volume, para ambos, quando comparados à fase inicial. O teor de sólidos total obtido após sete dias de ensaio foi de 31\% para o Sulfato de Alumínio e 28\% para o PACl. 

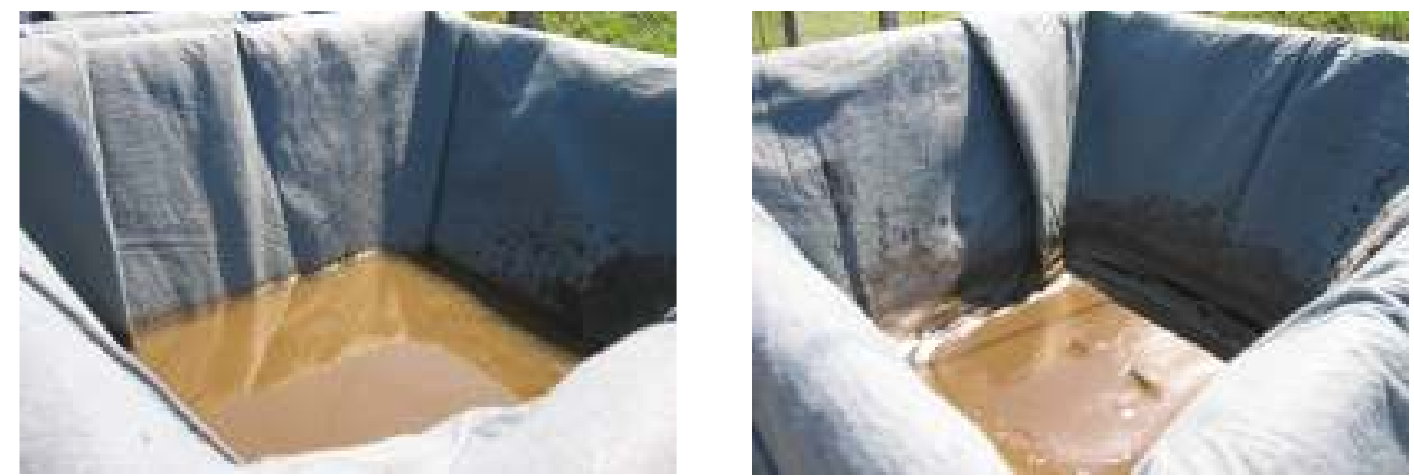

Sulfato de alumínio_10 minutos (ST=2,6\%)

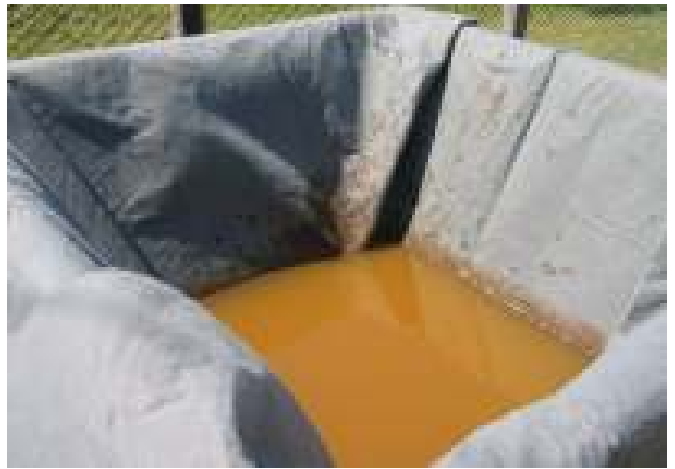

$\mathrm{PACl} \_10$ minutos $(\mathrm{ST}=1,4 \%)$

Sulfato de alumínio, 1 hora
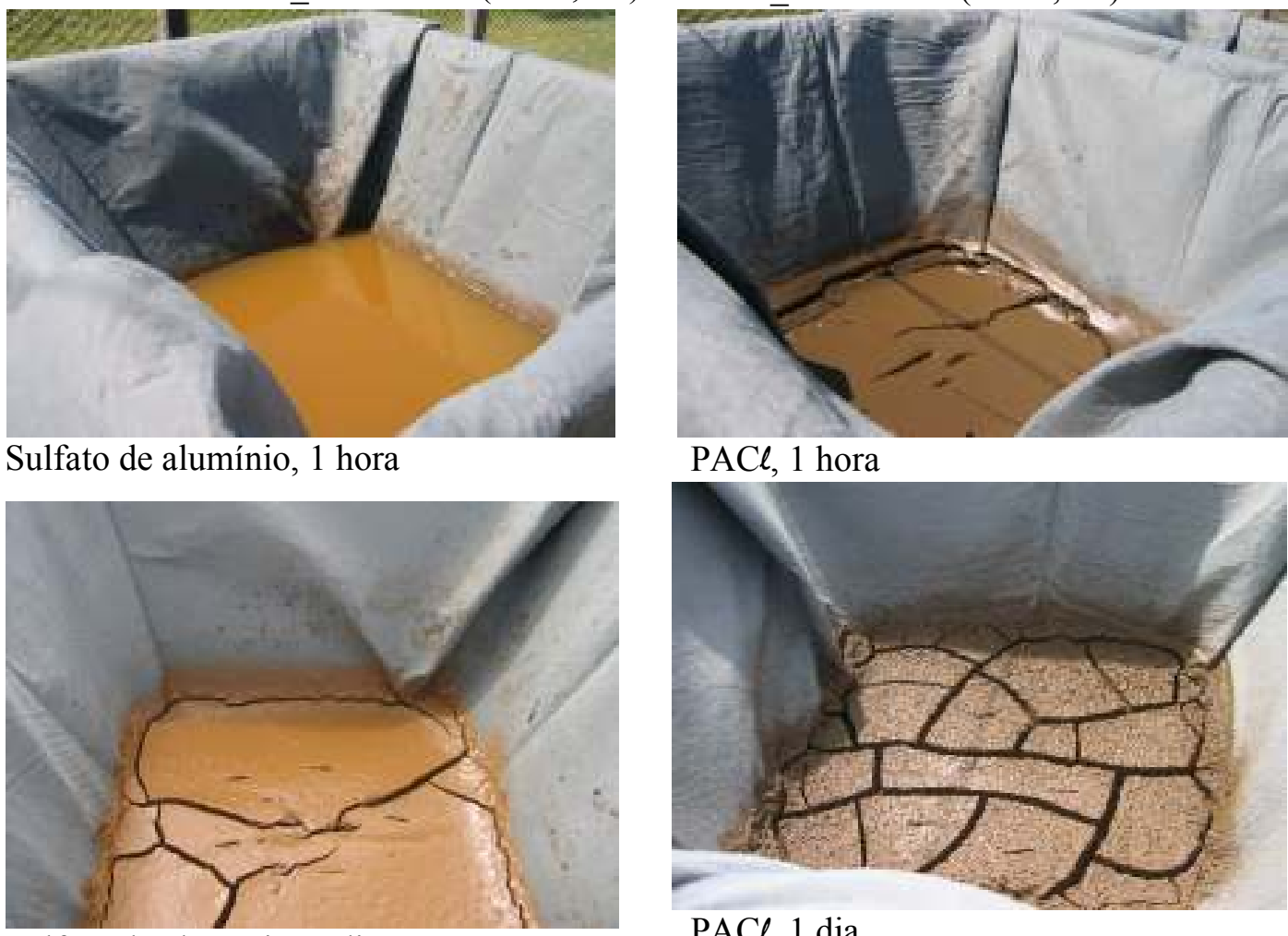

Sulfato de alumínio, 1 dia

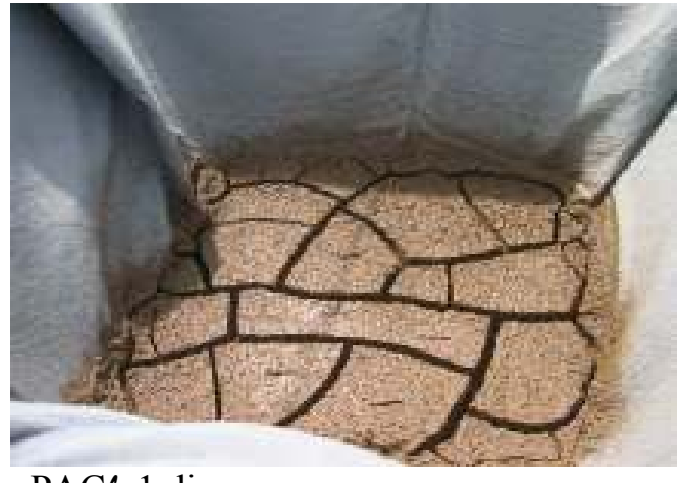

$\mathrm{PACl}, 1$ dia

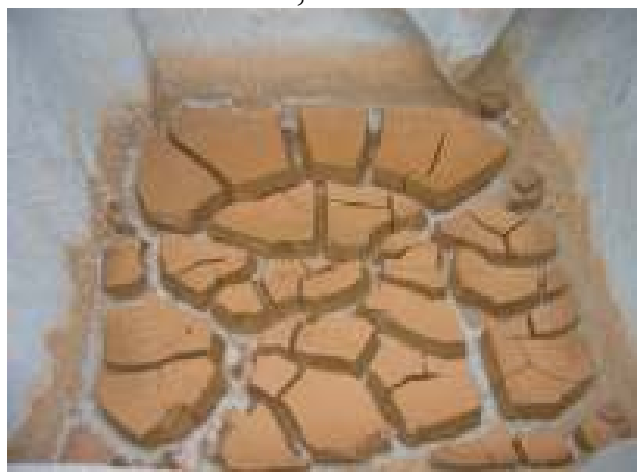

Sulfato de alumínio, 7 dias (ST=31\%)

Lodo de Sulfato de alumínio

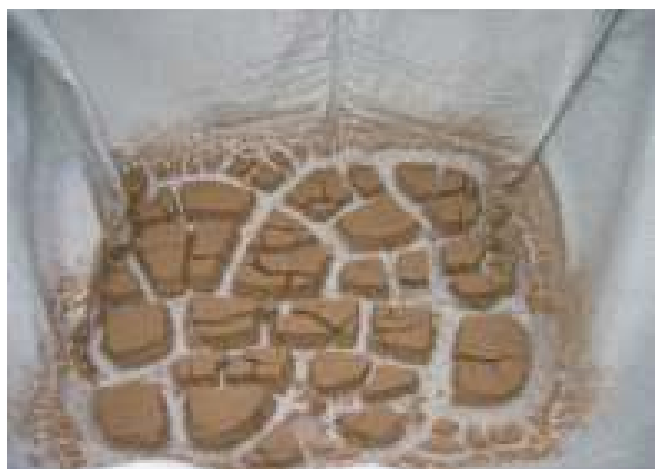

$\mathrm{PAC} \ell, 7$ dias $(\mathrm{ST}=28,4 \%)$

Lodo de PACl

Figura 6.13 - Fotos dos Leitos de Drenagem após 7 dias de aplicação dos lodos de Sulfato de Alumínio e PACl. 
Na Figura 6.14 apresenta-se a redução de volume de lodo obtido após o ensaio de desaguamento. Pode-se observar diminuição de volume de resíduo a ser disposto, tanto para lodo de sulfato de alumínio e PACl.

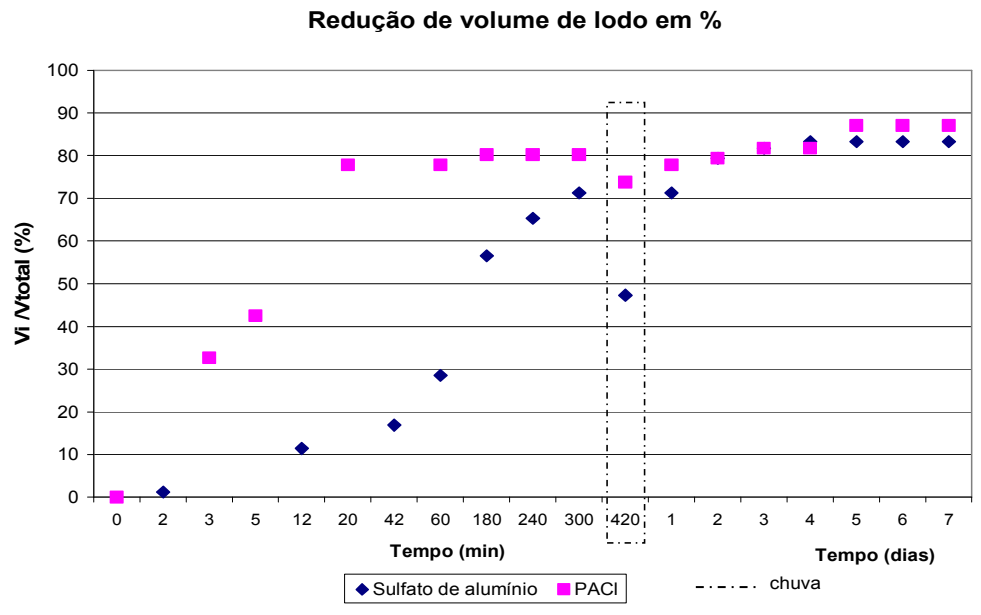

Figura 6.14 - Variação da redução de volume de lodo de Sulfato de alumínio e de PACl.

Ao fim de 7 dias houve redução de aproximadamente 83 e $87 \%$ do volume para os lodos de sulfato de alumínio e $\mathrm{PAC} \ell$ respectivamente. Destaca-se, que já no término da fase de drenagem (60 min para o $\mathrm{PACl}$ e 300 min para sulfato de alumínio), a redução de volume de lodo foi de aproximadamente $80 \%$.

\subsubsection{Ensaio 2}

No Ensaio 2, foi aplicado $20 \mathrm{~L}$ de amostras de lodo de PACl. As características gerais são apresentadas na Tabela 6.10.

Tabela 6.10 - Ensaio de sólidos sedimentáveis e concentração inicial de sólidos de lodo de $\mathrm{PACl}$ aplicado no leito de drenagem.

\begin{tabular}{c|c|c|c|c|c}
\hline \multirow{2}{*}{$\begin{array}{c}\text { Amostras de } \\
\text { lodo }\end{array}$} & ST (\%) & TAS & \multicolumn{3}{|c}{ Sólidos Sedimentáveis (mL/L) } \\
\cline { 4 - 6 } & & $\left.\mathbf{k g} / \mathbf{m}^{\mathbf{2}}\right)$ & $1 \mathrm{~h}$ & $2 \mathrm{~h}$ & $24 \mathrm{~h}$ \\
\hline $\mathrm{PACl}$ & 0,22 & 0,23 & 290 & 250 & 240 \\
\hline
\end{tabular}

Na Figura 6.15 é representado graficamente o resultado do ensaio de coluna de sedimentação, construída a partir da Tabela A5, Anexo A. 


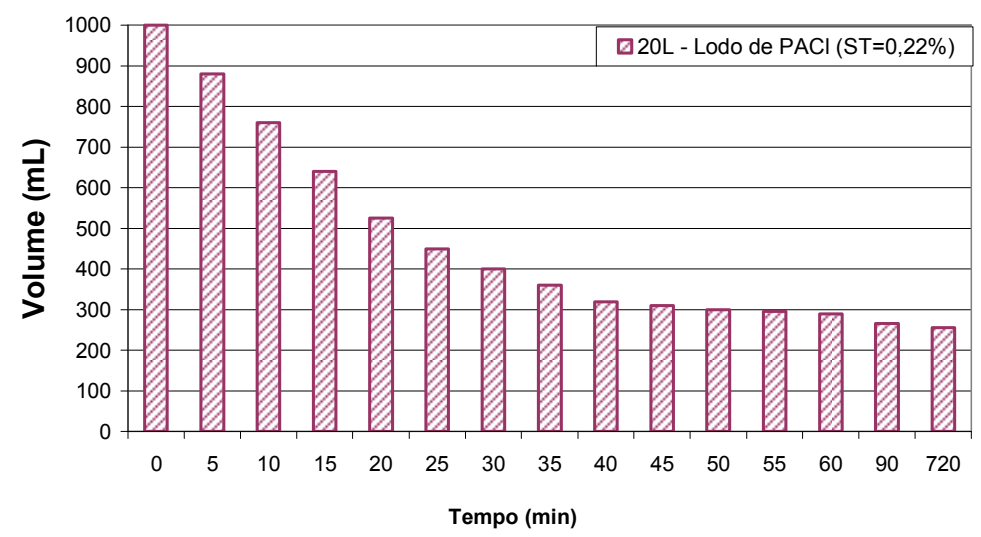

Figura 6.15 - Curva de sedimentação do lodo de PACl aplicado no Ensaio 2.

No Ensaio 2, a velocidade de sedimentação máxima até 30 minutos foi de Vs $=1,4$ $\mathrm{cm} / \mathrm{min}$ para o lodo de $\mathrm{PACl}$. No intervalo entre 45 e 90 minutos de ensaio a velocidade de sedimentação foi de $0,1 \mathrm{~cm} / \mathrm{min}$ e após esse tempo a sedimentação estabilizou-se.

\subsubsection{Aplicação e desaguamento dos lodos nos Leitos de Drenagem - Fase de Drenagem}

A amostra de lodo de PACl foi aplicada no Leito de Drenagem I. Os valores de vazão da água drenada com o tempo e o volume acumulado de água de drenagem são apresentados, respectivamente, na Figura 6.16 (a) e (b).

A vazão de drenagem inicial para o $\mathrm{PACl}$ foi de $4,62 \mathrm{~L} / \mathrm{min}$ e duração aproximada do tempo de drenagem de 60 minutos, conforme pode ser observado na Figura 6.16 (a). 


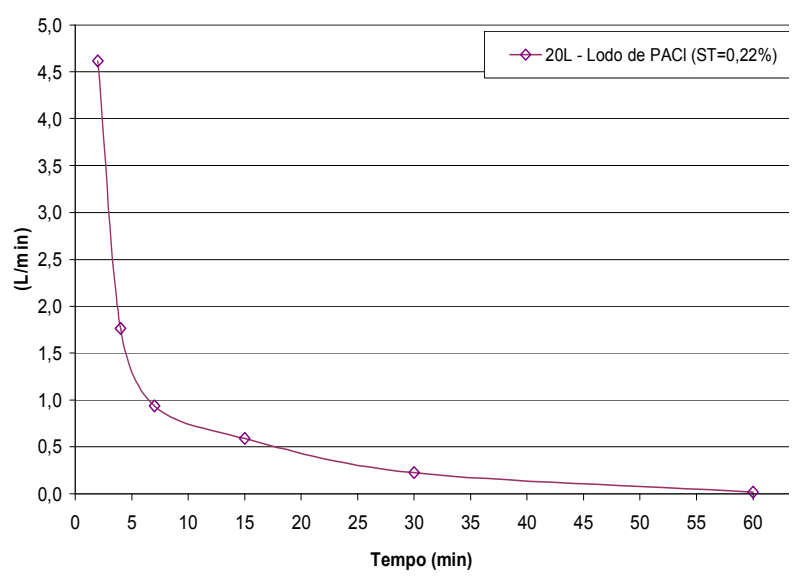

(a)

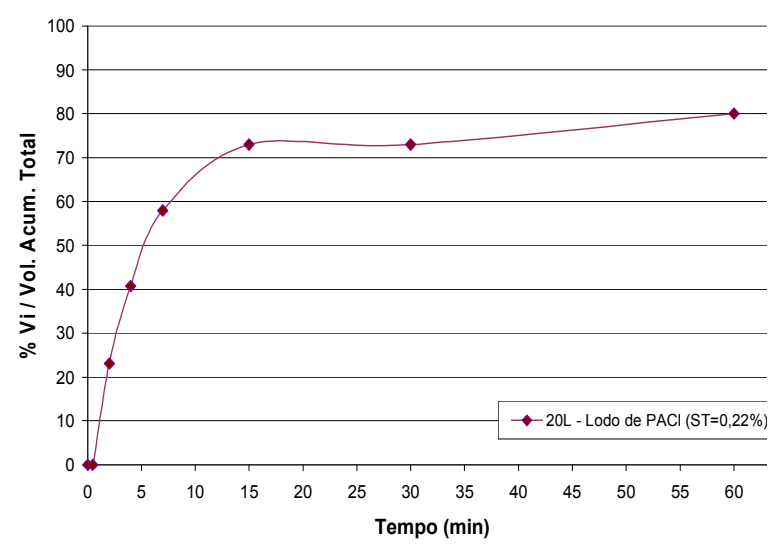

(b)

Figura 6.16 - Variação da vazão de drenagem da água livre em L/min (a) e volume acumulado de água livre drenada (b) proveniente da aplicação de lodo de PACl, Ensaio 2.

A drenagem de água livre para o PAC $\ell$ encerrou aproximadamente após 1 hora $(T d=$ 60 min), dando início às aberturas na massa do lodo e à secagem por evaporação. O volume acumulado coletado a partir da drenagem da água livre foi de aproximadamente $16 \mathrm{~L}$ ou $80 \%$ do volume total aplicado, conforme pode ser observado na Figura 6.16 (b).

A Figura 6.17 apresenta os resultados da variação de volume acumulado em (\%) e os valores de turbidez da água livre drenada durante a Fase de Drenagem.

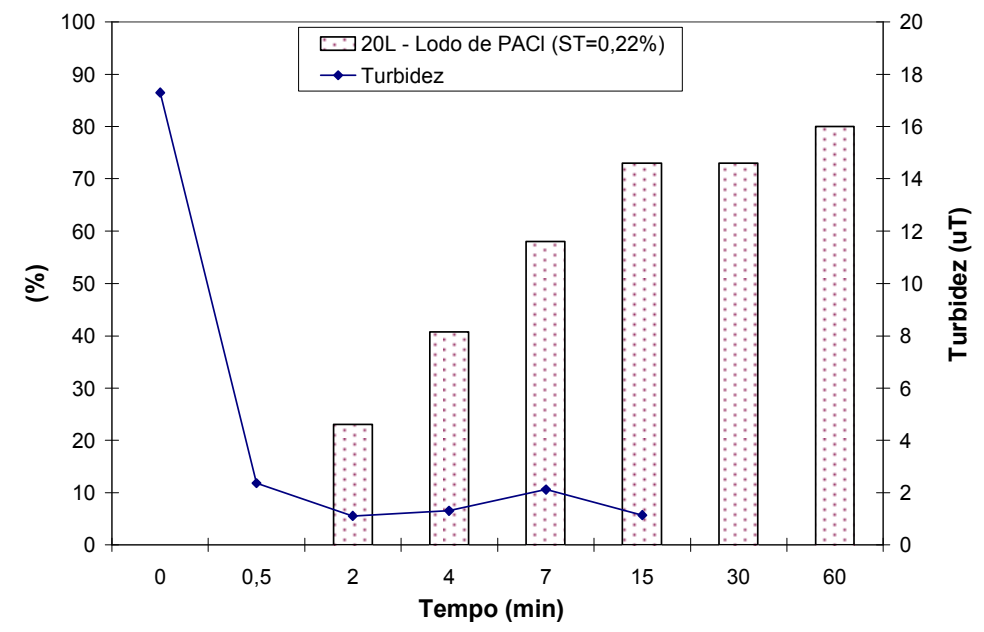

Figura 6.17 - Variação dos valores de volume acumulado de água livre drenada em (\%) e de turbidez durante a fase de drenagem, para amostra de lodos de $\mathrm{PACl}$, Ensaio 2. 
Pela Figura 6.17 observa-se que, para o lodo de $\mathrm{PACl}$, a água livre drenada já apresentava após 30 segundos, valor de turbidez de aproximadamente 2,4 uT, muito embora não tenha sido quantificado o volume acumulado. Cerca de $23,1 \%$ do volume de lodo aplicado foi drenado na forma de água livre no tempo de 2 minutos e apresentou valores de turbidez em torno de $1,5 \mathrm{uT}$.

\subsubsection{Desaguamento dos lodos nos Leitos de Drenagem - Fase de Secagem}

$\mathrm{Na}$ Tabela 6.11 é apresentado a variação diária de teor de sólidos no lodo de $\mathrm{PAC \ell}$ desaguado e retido na manta geotêxtil. O teor de sólidos total obtido após 24 horas foi aproximadamente de $13,0 \%$.

Os teores de sólidos do primeiro e segundo dia permaneceram em torno de $13 \%$, possivelmente explicados a partir da análise das variáveis climáticas. Após o terceiro dia, o teor de sólidos aumentou rapidamente até atingir aproximadamente $91,8 \%$ no sexto dia. No sétimo dia não foi possível retirar amostra de resíduos da manta geotêxtil.

Tabela 6.11 - Variação da concentração de sólidos para o lodo de PACl retido na manta do leito de drenagem, Ensaio 2.

\begin{tabular}{c|c}
\hline \multicolumn{2}{c}{ Amostra de lodo de PACl retido na manta do leito de drenagem } \\
\hline $\begin{array}{c}\text { Tempo } \\
(\text { dias })\end{array}$ & Valor de teor de sólidos \\
ST $(\%)$ \\
\hline 0 & 0,22 \\
\hline 1 hora & 5,10 \\
\hline 1 dias & 13,02 \\
\hline 2 dias & 13,53 \\
\hline 3 dias & 25,22 \\
\hline 4 dias & 85,94 \\
\hline 5 dias & 89,37 \\
\hline 6 dias & 91,76 \\
\hline
\end{tabular}




\subsubsection{Ensaio 3}

No Ensaio 3 foram aplicados $8 \mathrm{~L}$ de amostras de lodos de sulfato de alumínio e de PACl. As características gerais são apresentadas na Tabela 6.12 .

Tabela 6.12 - Caracterização dos resíduos utilizados nos ensaios de desaguamento por leito de drenagem.

\begin{tabular}{c|c|c|c}
\hline Amostras de lodo & ST $(\%)$ & TAS $\left(\mathrm{kg} / \mathrm{m}^{2}\right)$ & COT $(\mathrm{mg} / \mathrm{L})$ \\
\hline Sulfato de alumínio & 7,6 & 7,35 & 553 \\
\hline PACl & 0,04 & 0,04 & 107 \\
\hline
\end{tabular}

Na Figura 6.18 são representados graficamente os resultados dos ensaios de coluna de sedimentação.

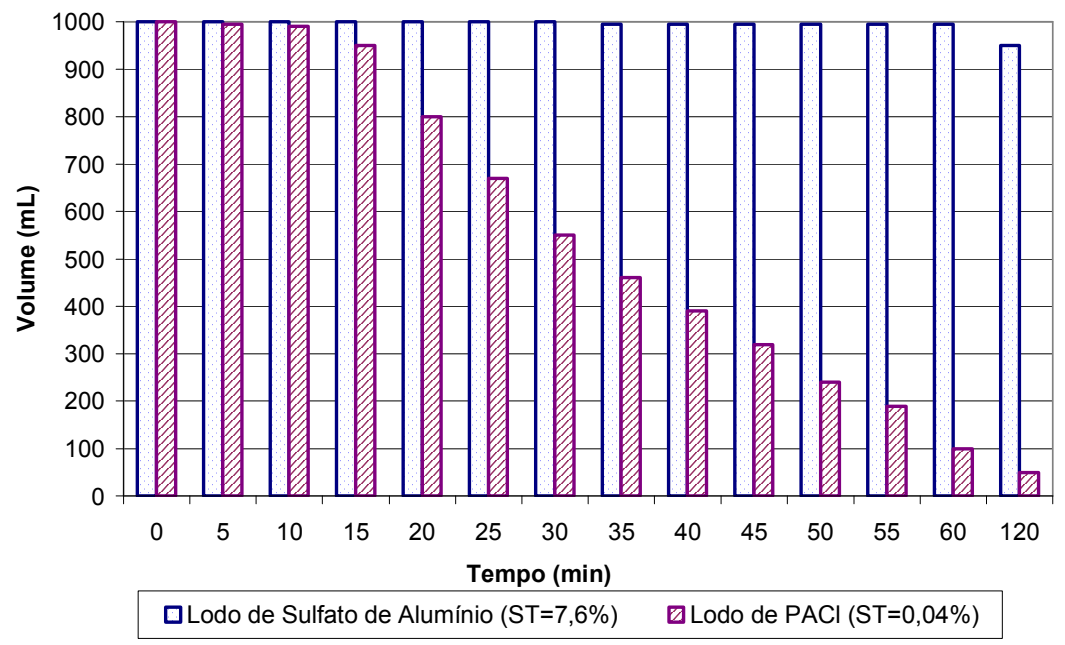

Figura 6.18 - Curva de sedimentação dos lodos de sulfato de alumínio e PACl.

No Ensaio 3, o lodo de sulfato de alumínio com $\mathrm{ST}=7,6 \%$, praticamente não sedimentou em função do elevado teor de sólidos. A sedimentação do lodo de PACl com ST $=0,04 \%$, caracterizou-se por assemelhar-se ao tipo sedimentação discreta com velocidade de sedimentação constante $\mathrm{Vs}=1,1 \mathrm{~cm} / \mathrm{min}$, a partir da formação de interface no tempo de 10 minutos e estabilizou-se praticamente com valor menor que $100 \mathrm{~mL}$ nos tempos 60 e 120 minutos. O lodo de $\mathrm{PACl}$ sedimentou rápido, em 45 minutos, com valor de aproximadamente 310 mL. Porém, ao contrário dos Ensaios 1 e 2 prosseguiu com rápida sedimentação, com valor aproximado de $100 \mathrm{~mL}$ para tempo de 60 minutos. 


\subsubsection{Aplicação dos lodos nos Leitos de Drenagem - Fase de Drenagem}

As amostras de lodo de sulfato de alumínio e de PACl foram aplicados nos Leitos de Drenagem II. Os valores de vazão da água drenada com o tempo são apresentados na Figura 6.19.

A vazão de drenagem inicial foi de $\mathrm{Q}=10 \mathrm{~L} / \mathrm{min}$, para lodo de PACl (TAS de 0,04 $\mathrm{kg} / \mathrm{m}^{2}$ ) e de $\mathrm{Q}=0,145 \mathrm{~L} / \mathrm{min}$ para o lodo de Sulfato de Alumínio (TAS de 7,35 kg/m² ). A vazão de drenagem do PACl apresentou-se mais elevada que para sulfato de alumínio, em todo período observado na fase de drenagem.

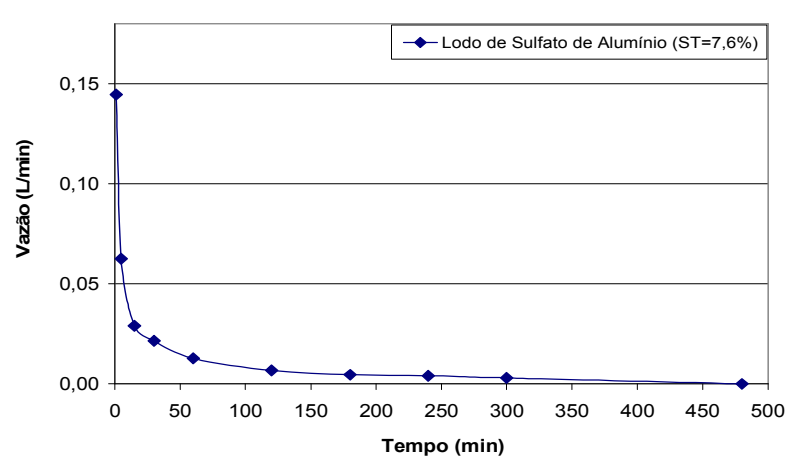

(a)

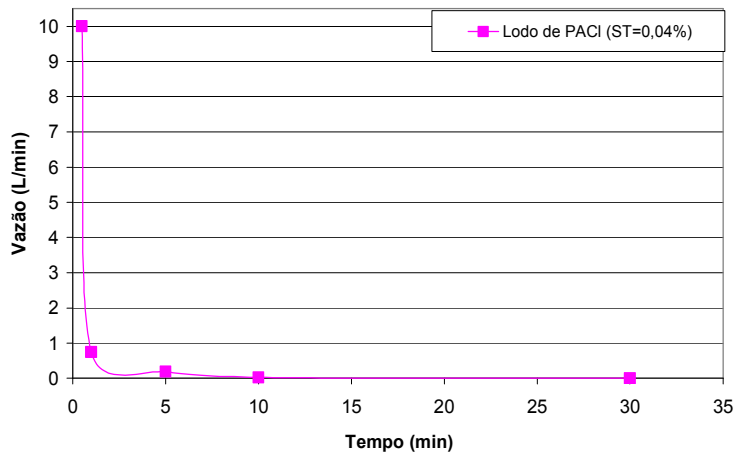

(b)

Figura 6.19 - Variação da vazão de drenagem de água livre para lodo de sulfato de alumínio(a) e de $\mathrm{PACl}$ (b).

A drenagem de água livre para o $\mathrm{PACl}$ encerrou aproximadamente após 30 minutos, tempo de drenagem, $T d=30$ minutos e para o lodo de sulfato de alumínio aproximadamente após 480 minutos, tempo de drenagem, $T d=480$ minutos ou 8 horas.

No término da fase de drenagem, os valores obtidos de teor de sólidos (ST\%) foram de $\mathrm{ST}=9,7 \%$ para o lodo de sulfato de alumínio e $\mathrm{ST}=1,8 \%$ para o lodo de PACl.

O volume acumulado, coletado a partir da drenagem da água livre foi de aproximadamente 7,6 L, ou cerca de $95 \%$ do volume total aplicado para o lodo de PACl. 
Para o lodo de sulfato de alumínio foi de 4,0 L ou $\mathbf{5 0} \%$ do volume total aplicado, conforme pode ser observado na Figura 6.20.

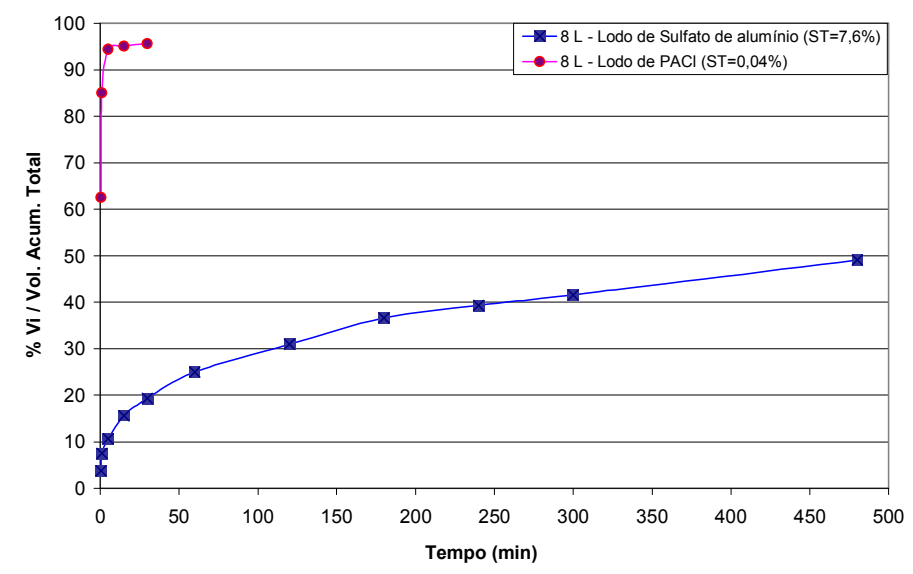

Figura 6.20 - Volume acumulado de drenagem da água livre para os lodos de sulfato de alumínio e $\mathrm{PACl}$.

A Figura 6.21 (a) e (b) apresenta os resultados em conjunto da variação de volume acumulado em (\%) e os valores de turbidez da água livre drenada durante a Fase de Drenagem. Para o lodo de sulfato de alumínio, no tempo de 30 minutos, cerca de $81 \%$ do volume de lodo aplicado foi drenado na forma de água livre e apresentou valores de turbidez abaixo de 7,5 uT.

Para o lodo de PACl, conforme pode ser observado na Figura 6.21 (b), a água drenada apresentou valor inicial de turbidez de aproximadamente $362 \mathrm{uT}$, para um volume acumulado de 62,5\% em 0,5 minuto ou 30 segundos. Após 1 minuto e volume acumulado de $85 \%$, a água livre drenada apresentou valores de turbidez abaixo de 15,5 uT. Assim, estes resultados mostraram que a qualidade da água drenada é distinta entre os lodos de sulfato de alumínio e lodo de $\mathrm{PACl}$ com teor de sólidos muito baixo ( $\mathrm{ST}=0,04 \%)$. 


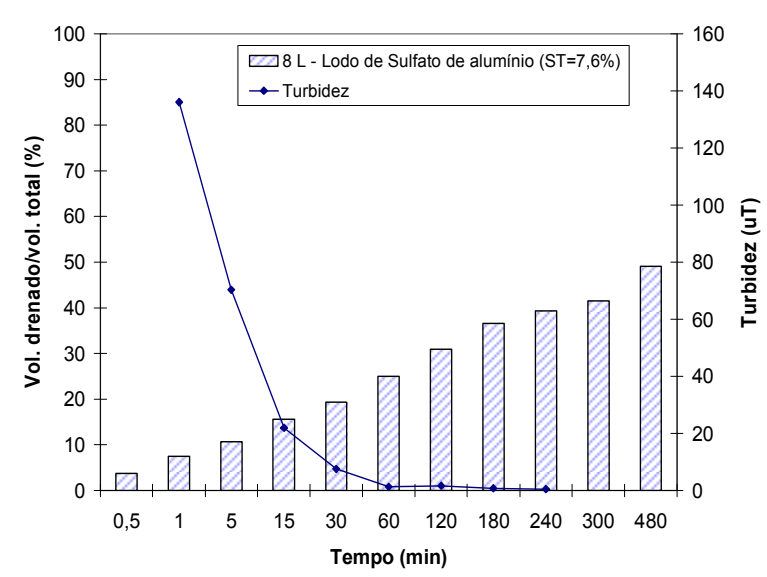

(a)

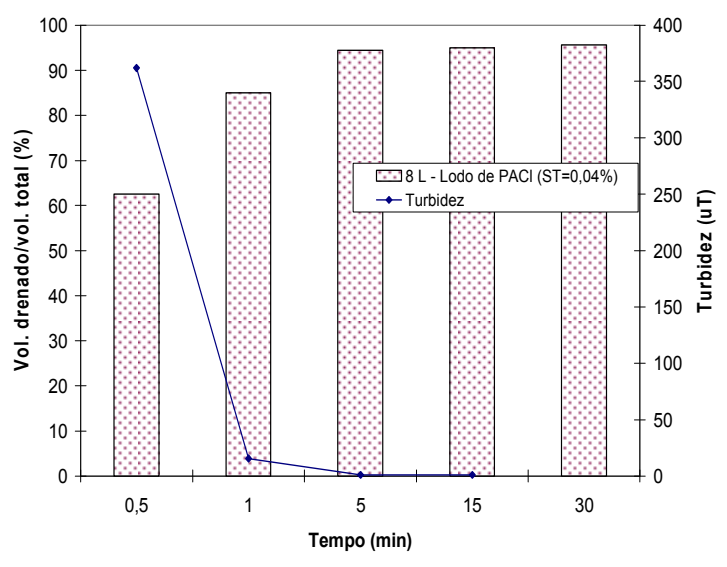

(b)

Figura 6.21 - Variação dos valores de volume acumulado de água livre drenada em (\%) e de turbidez durante a fase de drenagem. Para amostras de lodos de sulfato de alumínio (a) e de lodos de PACl(b).

\section{Fase de Secagem dos lodos nos Leitos de Drenagem}

Na Tabela 6.13 é apresentada a variação diária de teor de sólidos nas amostras de lodo de sulfato de alumínio e de $\mathrm{PACl}$ desaguados e retidos na manta geotêxtil.

O teor de sólidos totais, um dia após inicio do ensaio foi de $\mathrm{ST}=17,3 \%$ para o lodo de sulfato de alumínio e cerca de $13 \%$ para lodo de PACl.

O teor de sólidos final foi de $\mathrm{ST}=88,9 \%$ em sete dias para lodo de sulfato de alumínio e cerca de $\mathrm{ST}=50 \%$ em dois dias para o lodo de $\mathrm{PAC} \ell$.

Para o lodo de sulfato de alumínio, a secagem evoluiu continuamente até atingir ST = $37,5 \%$, a partir do qual elevou rapidamente para 93,7\%.

A partir do terceiro dia, a secagem do resíduo de $\mathrm{PACl}$ foi muito elevada e resultou em pequena quantidade de amostra entrelaçada nas fibras da manta geotêxtil (esturricou), o que inviabilizou a coleta de amostras para determinação de teor de sólidos (Tabela 6.13). 
Tabela 6.13 - Variação da concentração de sólidos para o resíduo de Sulfato de Alumínio e $\mathrm{PAC} \ell$ retidos na manta do leito de drenagem, Ensaio 3.

\begin{tabular}{c|c|c}
\hline \multirow{2}{*}{$\begin{array}{c}\text { Tempo } \\
\text { (dias) }\end{array}$} & \multicolumn{2}{|c}{$\begin{array}{c}\mid c \\
\text { ST (\%) }\end{array}$} \\
\cline { 2 - 3 } & Lodo de Sulfato de Alumínio & Lodo de PACl \\
\hline 0 & 7,6 & 0,04 \\
\hline 0,33 & 9,7 & 1,79 \\
\hline 1 dias & 17,3 & 13,02 \\
\hline 2 dias & 24,6 & 50,25 \\
\hline 3 dias & 28,3 & *esturricou \\
\hline 4 dias & 35,7 & *esturricou \\
\hline 5 dias & 37,5 & *esturricou \\
\hline 6 dias & 93,7 & *esturricou \\
\hline 7 dias & 88,9 & *esturricou \\
\hline
\end{tabular}

* Não foi possível coletar amostras, pois os sólidos ficaram "presos" na manta.

\subsubsection{Ensaio 4}

No Ensaio 4 foram aplicados 55 L de amostras de lodos de sulfato de alumínio e de PACl. As características gerais são apresentadas na Tabela 6.14 .

Tabela 6.14 - Caracterização dos resíduos utilizados nos ensaios de desaguamento por leito de drenagem, Ensaio 4.

\begin{tabular}{c|c|c|c}
\hline Amostras de lodo & ST (\%) & TAS $\left(\mathrm{kg} / \mathrm{m}^{2}\right)$ & COT $(\mathrm{mg} / \mathrm{L})$ \\
\hline Sulfato de alumínio & 0,76 & 2,20 & 133,8 \\
\hline PACl & 0,26 & 0,76 & 36,1 \\
\hline
\end{tabular}

Na Tabela 6.15 são apresentados os resultados dos ensaios de determinação de sólidos sedimentáveis realizados com as amostras brutas de lodo de sulfato de alumínio e PACl.

Tabela 6.15 - Resultado do ensaio de sólidos sedimentáveis das amostras de lodo de sulfato de alumínio e de $\mathrm{PACl}$, usadas no ensaio de desaguamento por leito de drenagem.

\begin{tabular}{c|c|c}
\hline \multirow{2}{*}{ Amostras de lodo } & \multicolumn{2}{|c}{ Sólidos Sedimentáveis (mL/L) } \\
\cline { 2 - 3 } & $1 \mathrm{~h}$ & $2 \mathrm{~h}$ \\
\hline Sulfato de alumínio & 990 & 980 \\
\hline PACl & 50 & $<50$ \\
\hline
\end{tabular}

Na Figura 6.22 são representados graficamente os resultados dos ensaios de coluna de sedimentação. 


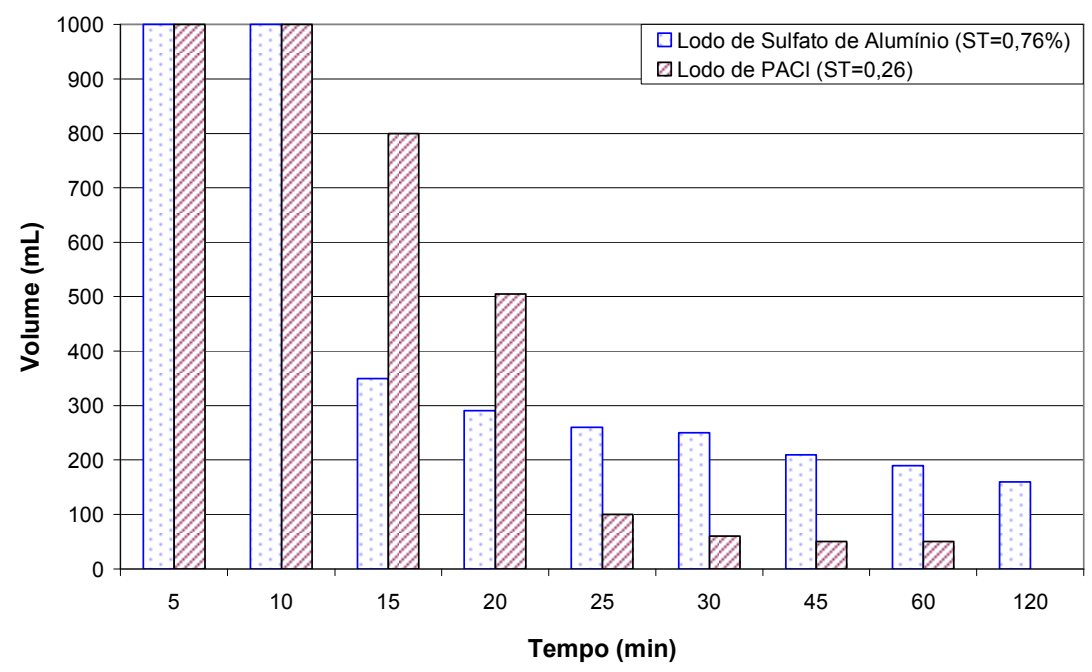

Figura 6.22 - Curva de sedimentação dos lodos de sulfato de alumínio e de PACl.

O lodo de sulfato de alumínio com $\mathrm{ST}=0,76 \%$ apresentou velocidade de sedimentação máxima de 2,6 cm/min nos intervalos entre 5 e 15 minutos. Assim como nos Ensaios 1 e 3, também apresentou tendência de estabilizar após 45 minutos.

O lodo de $\mathrm{PACl}$ apresentou velocidade de sedimentação máxima de 3,6 cm/min no intervalo de 10 minutos $(1000 \mathrm{~mL})$ a 25 minutos $(100 \mathrm{~mL})$. A partir de 45 minutos desenvolveu baixa velocidade de sedimentação e apresentou valores menores que $50 \mathrm{~mL}$. Salienta-se que a identificação da interface clarificado-sedimentado foi de difícil visualização para as duas amostras de lodo.

\subsubsection{Aplicação e Desaguamento dos lodos nos Leitos de Drenagem - Fase de Drenagem}

As amostras de lodo de sulfato de alumínio e de PACl foram aplicadas nos Leitos de Drenagem I. Os valores de vazão da água drenada com o tempo são apresentados na Figura 6.23 .

A partir da Figura 6.23, observa-se que a vazão de drenagem inicial foi de $Q=2,40$ $\mathrm{L} / \mathrm{min}$, para lodo de PACl (TAS de $0,76 \mathrm{~kg} / \mathrm{m}^{2}$ ) e de $\mathrm{Q}=1,25 \mathrm{~L} / \mathrm{min}$ para lodo de Sulfato de Alumínio (TAS de 2,20 kg/m²). A vazão de drenagem apresentou-se mais elevada para o lodo 
de PACl que para o de sulfato de alumínio, tendência observada em todo o período compreendido na fase de drenagem.

A drenagem de água livre para o lodo de sulfato de alumínio ocorreu até 300 minutos, tempo de drenagem, $\mathrm{Td}=300$ minutos e para o lodo de $\mathrm{PACl}$ encerrou aproximadamente após 60 minutos, tempo de drenagem, $T d=60$ minutos.

No término da fase de drenagem, os valores obtidos de teor de sólidos (ST\%) foi de $\mathrm{ST}=12,6 \%$ para o lodo de sulfato de alumínio e $\mathrm{ST}=5,1 \%$ para o lodo de PACl.

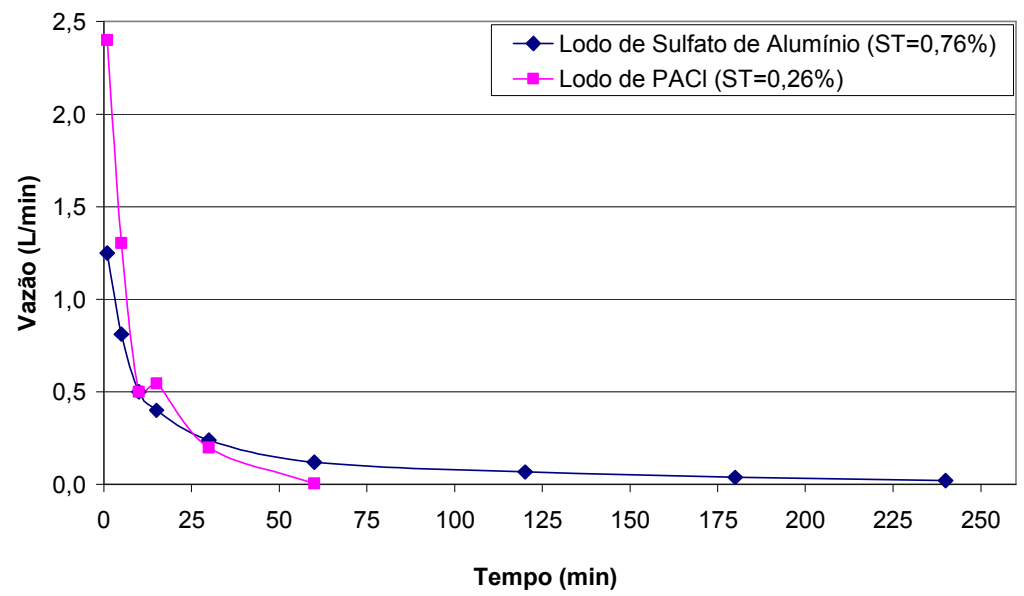

Figura 6.23 - Variação da vazão de drenagem da água livre (em L/min) para os lodos de sulfato de alumínio e $\mathrm{PACl}$ durante as primeiras 4 horas.

O volume acumulado coletado a partir da drenagem da água livre foi de aproximadamente $48 \mathrm{~L}$ ou cerca de $87 \%$ do volume total aplicado, para o lodo de sulfato de alumínio. Para o lodo de PACl foi de aproximadamente $52 \mathrm{~L}$ ou cerca de $93 \%$ do volume total aplicado, conforme pode ser observado na Figura 6.24. 


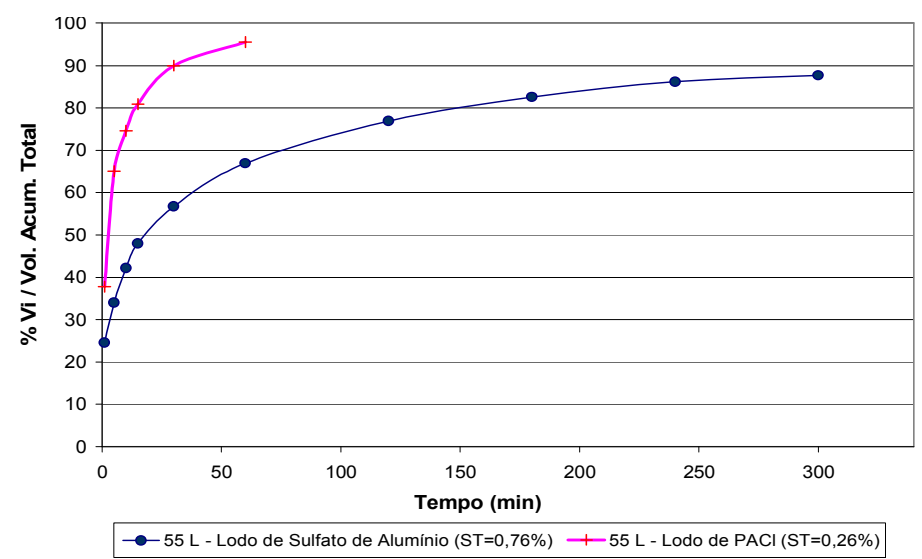

Figura 6.24 - Volume acumulado de drenagem da água livre para os lodos de sulfato de alumínio e PACl.

A Figura 6.25 (a) e (b) apresentam os resultados em conjunto da variação de volume acumulado em (\%) e os valores de turbidez da água livre drenada. Na Figura 6.25 (a) observase que, para o lodo de sulfato de alumínio, cerca de $24,5 \%$ do volume de lodo aplicado foi drenado na forma de água livre no tempo de 1 minuto, com valor de turbidez acima de $60 \mathrm{uT}$. Após 5 minutos de ensaio, havia drenado cerca de $66 \%$ do volume de lodo aplicado com valores de turbidez abaixo de $16,7 \mathrm{uT}$.

Para o lodo de PACl, ilustrado na Figura 6.25 (b), a água drenada apresentou valor inicial de turbidez de aproximadamente $213 \mathrm{uT}$, para um volume acumulado de $37,8 \%$ em 1 minuto. Após 5 minutos e volume acumulado de $65 \%$, a água livre drenada apresentou valores de turbidez próximos de 2,0 uT. 


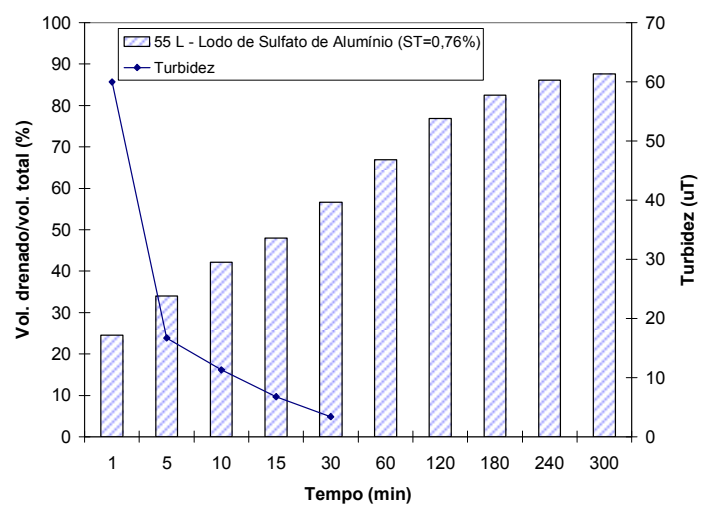

(a)

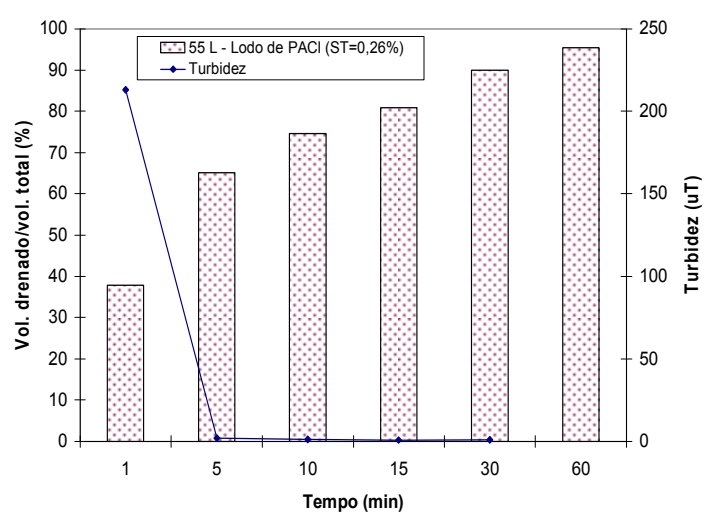

(b)

Figura 6.25 - Variação dos valores de volume acumulado de água livre drenada em (\%) e turbidez durante a fase de drenagem. Para amostras de lodos de sulfato de alumínio (a) e de lodos de PACl (b).

\section{Fase de Secagem dos lodos nos Leitos de Drenagem}

Na Tabela 6.16 é apresentada a variação diária de teor de sólidos nas amostras de lodo de sulfato de alumínio e de $\mathrm{PAC} \ell$ desaguados e retidos na manta geotêxtil.

O teor de sólidos totais, um dia após inicio do ensaio foi de ST=23,4 \% para o lodo de sulfato de alumínio e cerca de $16,7 \%$ para lodo de $\mathrm{PACl}$.

Após o terceiro dia, o teor de sólidos aumentou rapidamente até atingir aproximadamente $98,10 \%$ no sexto dia. No terceiro dia para o lodo de $\mathrm{PACl}$ e sétimo dia para o lodo de sulfato de alumínio não foi possível retirar amostra de resíduos da manta geotêxtil.

O teor de sólidos final foi de $\mathrm{ST}=98,10 \%$ em seis dias para lodo de sulfato de alumínio e cerca de $\mathrm{ST}=46,5 \%$ em dois dias para o lodo de $\mathrm{PACl}$. 
Tabela 6.16 - Variação da concentração de sólidos para o resíduo de PACl retido na manta do leito de drenagem, Ensaio 4.

\begin{tabular}{c|c|c}
\hline \multirow{2}{*}{$\begin{array}{c}\text { Tempo } \\
\text { (dias })\end{array}$} & \multicolumn{2}{|c}{ Variação de teor de sólidos } \\
\cline { 2 - 3 } & LT (\%) \\
\hline 0 & 0,76 & Lodo de PACl \\
\hline 0,33 & 12,60 & 0,26 \\
\hline 1 dias & 23,41 & 5,10 \\
\hline 2 dias & 55,21 & 16,73 \\
\hline 3 dias & 72,31 & 46,55 \\
\hline 4 dias & 96,67 & $*$ esturricou \\
\hline 5 dias & 93,33 & $*$ esturricou \\
\hline 6 dias & 98,10 & $*$ esturricou \\
\hline
\end{tabular}

* Não foi possível coletar amostras, pois sólidos "grudou” na manta geotêxtil.

\subsubsection{Ensaio 5 (5A e 5B)}

O Ensaio 5 foi dividido em dois ensaios 5A e 5B. O volume de amostra de lodo utilizado em cada ensaio foi de 8 L. As características gerais são apresentadas na Tabela 6.17.

Tabela 6.17 - Caracterização dos lodos usados nos ensaios de desaguamento por leito de drenagem, Ensaios 5A e 5B.

\begin{tabular}{|c|c|c|}
\hline Ensaio 5A & ST (\%) & TAS $\left(\mathrm{kg} / \mathrm{m}^{2}\right)$ \\
\hline Lodo de Sulfato de alumínio & 2,7 & 2,61 \\
\hline Lodo de PACl & 0,28 & 0,27 \\
\hline Ensaio 5B & \multicolumn{2}{|}{} \\
\hline Lodo de Sulfato de alumínio & 4,2 & 4,06 \\
\hline Lodo de PACl & 0,21 & 0,20 \\
\hline
\end{tabular}

As amostras dos Ensaios 5A e 5B não foram submetidas a ensaios para determinação dos sólidos sedimentáveis.

\subsubsection{Aplicação e Desaguamento dos lodos nos Leitos de Drenagem}

As amostras de lodo de sulfato de alumínio e de PACl foram aplicadas nos Leitos de Drenagem II. Os valores de vazão da água drenada com o tempo são apresentados na Figura 6.26 e 6.27, respectivamente Ensaio 5A e Ensaio 5B. 
Para o Ensaio 5A, a Figura 6.26 mostra que a vazão de drenagem inicial foi de 0,60 $\mathrm{L} /$ min para lodo de sulfato de alumínio (TAS de $2,61 \mathrm{~kg} / \mathrm{m}^{2}$ ) e $3,0 \mathrm{~L} / \mathrm{min}$, para lodo de PACl (TAS de $0,27 \mathrm{~kg} / \mathrm{m}^{2}$ ). A vazão de drenagem do PACl apresentou-se mais elevada que para sulfato de alumínio, tendência esta apresentada até o final da fase de drenagem.

A drenagem de água livre para o lodo de sulfato de alumínio ocorreu até 120 minutos, tempo de drenagem, $T d=120$ minutos, e para o lodo de PACl encerrou aproximadamente após 10 minutos, tempo de drenagem, $T d=10$ minutos. Os valores obtidos de teor de sólidos (ST \%) no término da fase de drenagem foi de $\mathrm{ST}=18,3 \%$ para o lodo de sulfato de alumínio e para o lodo de PACl não foi possível determinar devido pequena quantidade de sólidos retido e disponíveis na manta geotêxtil.

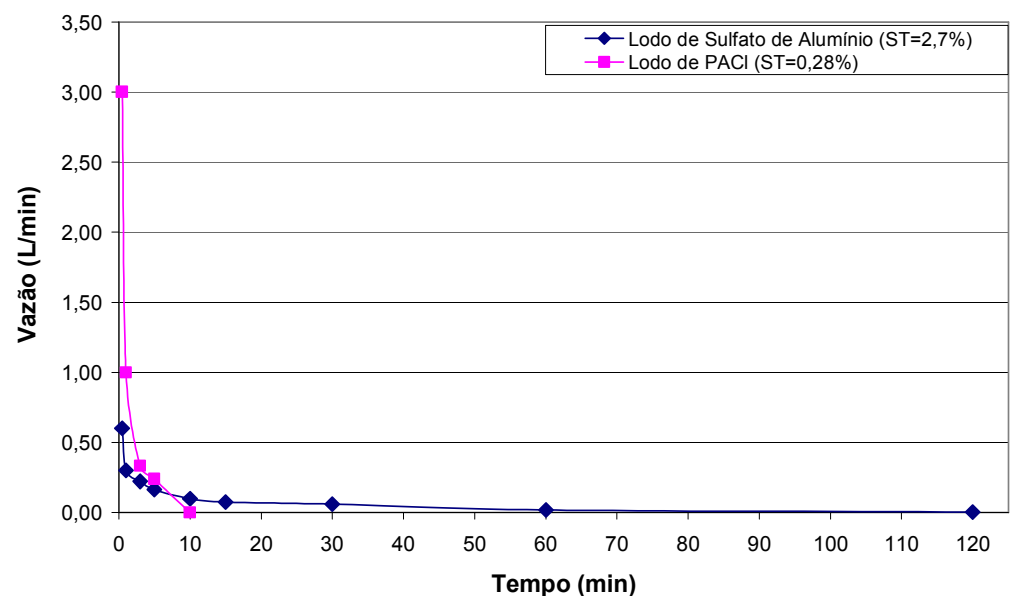

Figura 6.26 - Variação da vazão de drenagem da água livre (em L/min) para os lodos de sulfato de alumínio e PACl, Ensaio 5A.

Para o Ensaio 5B, a Figura 6.27 mostra que a vazão de drenagem inicial foi de 0,20 L/min para lodo de Sulfato de Alumínio (TAS de 4,06 kg/m²) e 6,0 L/min, para lodo de PACl (TAS de $0,20 \mathrm{~kg} / \mathrm{m}^{2}$ ).

A drenagem de água livre para o lodo de sulfato de alumínio ocorreu até 120 minutos, tempo de drenagem, $\mathrm{Td}=120$ minutos, e para o lodo de $\mathrm{PACl}$ encerrou aproximadamente após 10 minutos, tempo de drenagem, $\mathrm{Td}=10$ minutos. 
O teor de sólidos (ST\%) no término da fase de drenagem foi ST $=14,5 \%$ para o lodo de sulfato de alumínio e para o lodo de $\mathrm{PAC} \ell$ não foi possível determinar devido pequena quantidade de sólidos retidos e disponíveis na manta geotêxtil.

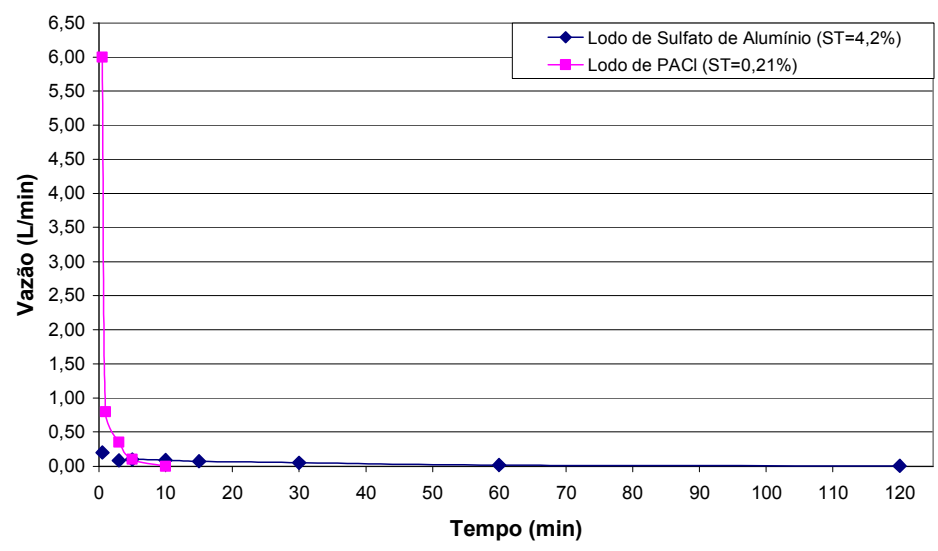

Figura 6.27 - Variação da vazão de drenagem da água livre (em L/min) para os lodos de sulfato de alumínio e PACl, Ensaio 5B.

A Figura 6.28 mostra a comparação entre os dois lodos de sulfato de alumínio, para os valores de vazão de drenagem. Até 10 minutos após início dos ensaios, o lodo com menor teor de sólidos, Ensaio 5A ( $\mathrm{ST}=2,7 \%$ ) apresentou vazões de drenagem maiores que o lodo de maior teor de sólidos, Ensaio 5B (ST = 4,2 \%), a partir do qual apresentaram aproximadamente os mesmos valores de vazão de drenagem.

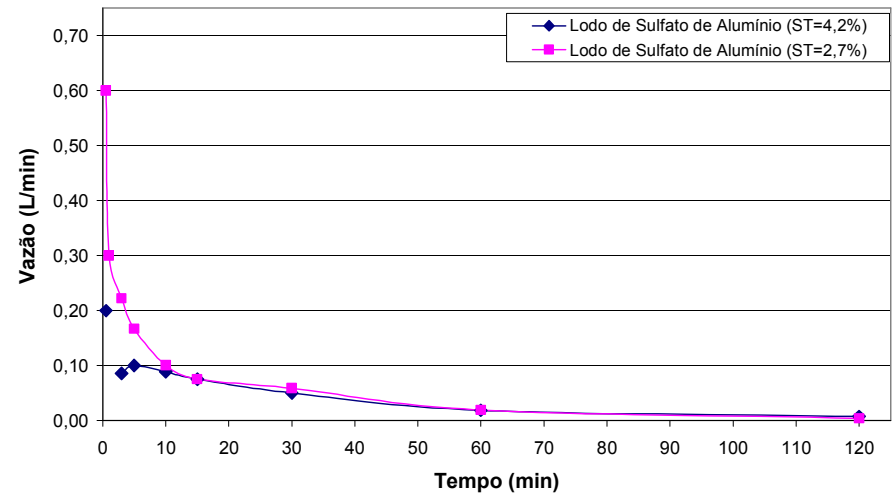

Figura 6.28 - Variação da vazão de drenagem da água livre (em L/min) para os lodos de sulfato de alumínio entre Ensaio 5A e Ensaio 5B.

A Figura 6.29 mostra a comparação entre os dois lodos de PACl. As amostras de lodo de $\mathrm{PACl}$ apresentaram aproximadamente os mesmos valores de teor de sólidos, Ensaio 5A 
$(\mathrm{ST}=0,28 \%)$ e Ensaio 5B $(\mathrm{ST}=0,21 \%)$. Apesar disso, a vazão de drenagem inicial de água livre do lodo do Ensaio 5B (ST = 0,21\%) foi praticamente o dobro, cerca de 6,0 L/min do valor do Ensaio 5A (ST=0,28 \%), em torno de 3,0 L/min. Contudo, após um minuto de ensaio os valores de vazão igualaram-se.

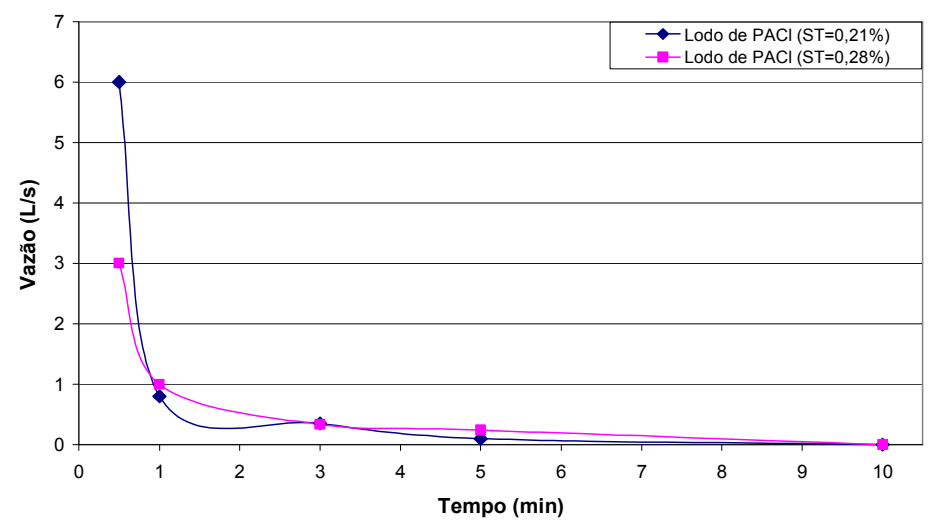

Figura 6.29 - Variação da vazão de drenagem da água livre (em L/min) para os lodos de PACl entre Ensaio 5A e Ensaio 5B.

Nas Figuras 6.30 e 6.31 são representados os resultados de variação de percentual de volume acumulado para os lodos de sulfato de alumínio e de PACl (Ensaios 5A e 5B).

Para o lodo de Sulfato de Alumínio, a drenagem de água livre prosseguiu por aproximadamente 2 horas (Fase de Drenagem), conforme pode ser observado na Figura 6.30, quando só então atingiu o volume acumulado de aproximadamente 4,0 a $4,5 \mathrm{~L}$, ou 49 a $58 \%$ do volume total aplicado.

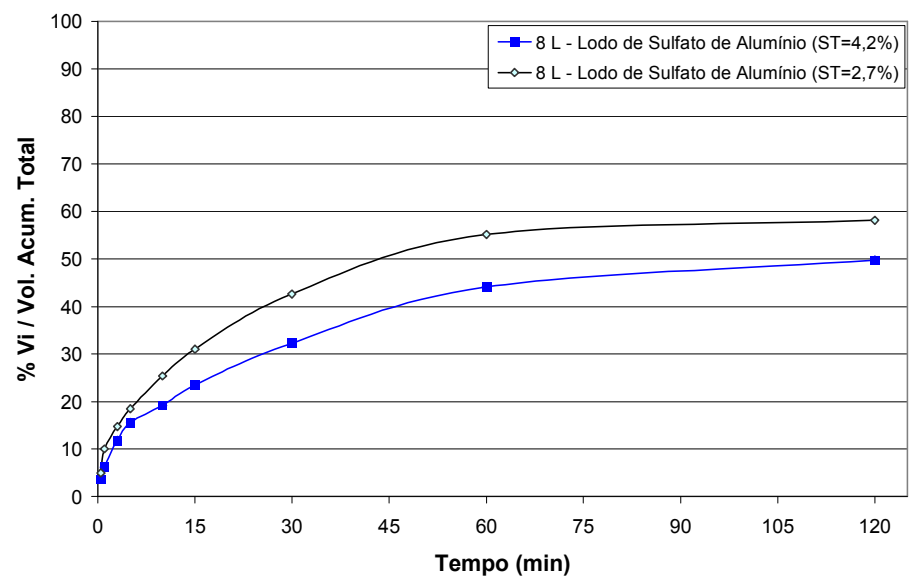

Figura 6.30 - Variação em porcentagem de volume acumulado de drenagem da água livre para os lodos de Sulfato de Alumínio (Ensaios 5A e 5B). 
Para o Lodo de PACl, o volume acumulado total de água livre drenada foi de aproximadamente 7,6 L ou $96 \%$ do volume total aplicado no Ensaio 5A e 5B (Figura 6.31).

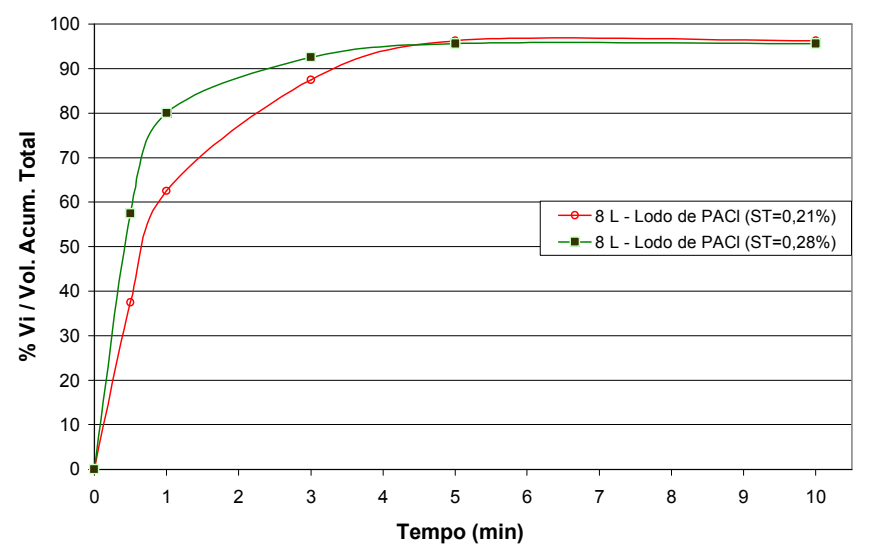

Figura 6.31 - Variação em porcentagem de volume acumulado de drenagem da água livre para os lodos de $\mathrm{PACl}$ (Ensaios 5A e 5B).

A Figura 6.32 (a) e (b) apresenta os resultados da variação de volume acumulado em (\%) e os valores de turbidez da água livre drenada durante a Fase de Drenagem no Ensaio 5A.

Para o lodo de sulfato de alumínio, cerca de $75 \%$ do volume de lodo aplicado foi drenado na forma de água livre em 10 minutos, com valor de turbidez abaixo de 17,1 uT.

Para o lodo de PACl, apresentado na Figura 6.32 (b), a água drenada apresentou valor inicial de turbidez de aproximadamente $137 \mathrm{uT}$, para um volume acumulado de 57,5\% em 0,5 minuto ou 30 segundos. Após 1 minuto e volume acumulado de $80 \%$, a água livre drenada apresentou valores de turbidez próximos de $25 \mathrm{uT}$. 


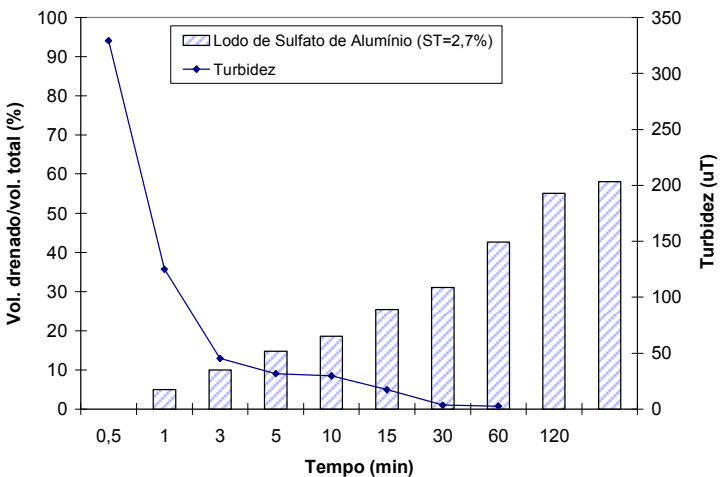

(a)

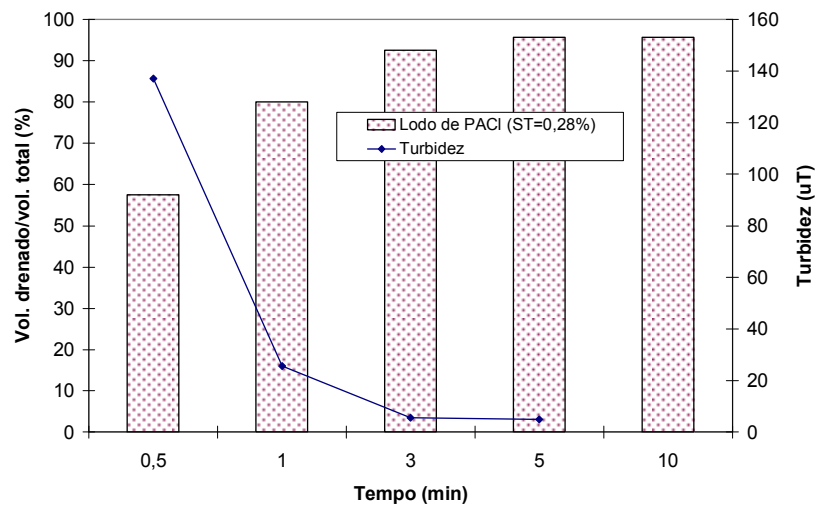

(b)

Figura 6.32 - Variação dos valores de volume acumulado de água livre drenada em (\%) e de turbidez para amostras de lodos de sulfato de alumínio (a) e de lodos de PACl (b), Ensaio 5A.

Na Figura 6.33 (a) e (b) apresentam-se os resultados para o Ensaio 5B.

Para o lodo de sulfato de alumínio, cerca de $81 \%$ do volume de lodo aplicado foi drenado na forma de água livre em 10 minutos, com turbidez abaixo de 22,2 uT.

Para o lodo de $\mathrm{PACl}$, a água drenada apresentou valor inicial de turbidez de aproximadamente $588 \mathrm{uT}$, para um volume acumulado de $37,5 \%$ em 0,5 minuto ou 30 segundos. Após 3 minutos e volume acumulado de 87,5 \%, a água livre drenada apresentou valores de turbidez próximos de $8 \mathrm{uT}$.

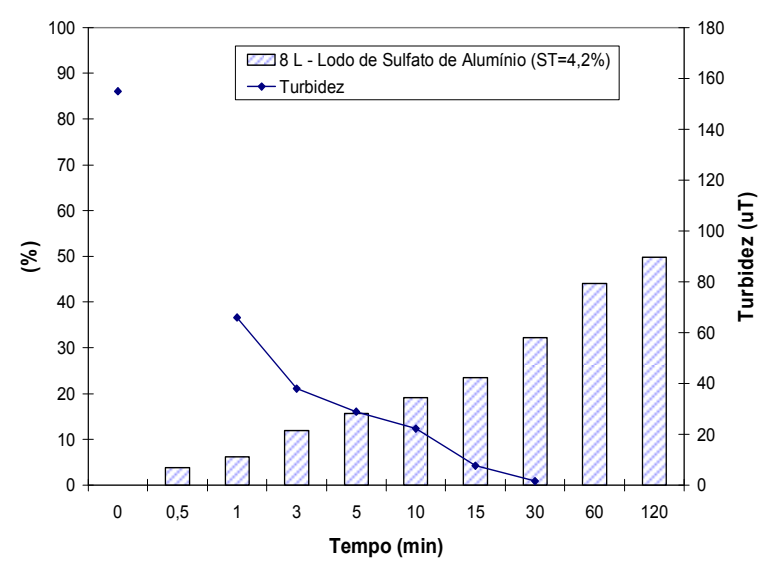

(a)

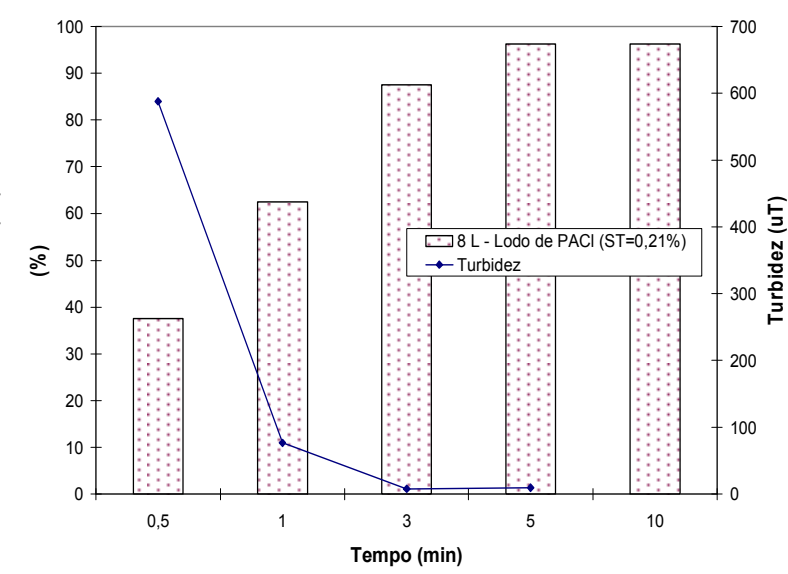

(b)

Figura 6.33 - Variação dos valores de volume acumulado de água livre drenada em (\%) e de turbidez para as amostras de lodos de sulfato de alumínio (a) e de lodos de $\mathrm{PACl}$ (b), Ensaio $5 \mathrm{~B}$. 


\section{Fase de Secagem dos lodos nos Leitos de Drenagem}

Na Tabela 6.18 é apresentado a variação diária de teor de sólidos nas amostras de lodo de sulfato de alumínio e de $\mathrm{PACl}$ desaguados e retidos na manta geotêxtil.

Para os lodos de sulfato de alumínio, o teor de sólidos total, um dia após inicio do ensaio foi de $\mathrm{ST}=18,3 \%$ para Ensaio $5 \mathrm{~A}\left(\mathrm{ST}_{\mathrm{o}}=2,7 \%\right)$ e $\mathrm{ST}=14,2 \%$ para Ensaio $5 \mathrm{~B}\left(\mathrm{ST}_{\mathrm{o}}\right.$ $=4,2 \%)$. Já, os lodos desaguados de $\mathrm{PACl}$ esturricaram e aderiram à manta após um dia de ensaio e não possibilitaram coletar amostras para determinação do teor de sólidos.

Os valores de teor de sólidos nos lodos de sulfato de alumínio elevaram-se rapidamente até o terceiro dia $(\mathrm{ST}=39,8 \%)$ para o Ensaio $5 \mathrm{~A}$ e até o quarto dia ( $\mathrm{ST}=38,5 \%$ ) para o Ensaio 5B, quando houve ocorrência de chuva. O teor de sólidos final foi obtido em sete dias com $\mathrm{ST}=50,3 \%$ para Ensaio $5 \mathrm{~A}$ e $\mathrm{ST}=42,3 \%$ para Ensaio $5 \mathrm{~B}$.

Tabela 6.18 - Variação do teor de sólidos para as amostras de lodo desaguado e retido na manta do leito de drenagem (lodo de sulfato de alumínio e de PACl).

\begin{tabular}{|c|c|c|c|c|}
\hline \multirow[b]{2}{*}{$\begin{array}{l}\text { Tempo } \\
\text { (dias) }\end{array}$} & \multicolumn{4}{|c|}{ Variação de teor de sólidos em (\%) das amostras retidas na manta geotextil } \\
\hline & $\begin{array}{c}\text { Lodo de Sulfato de } \\
\text { Alumínio } \\
\text { (ST=4,2\%) }\end{array}$ & $\begin{array}{l}\text { Lodo de Sulfato de } \\
\text { Alumínio } \\
(\mathrm{ST}=2,7 \%) \\
\end{array}$ & $\begin{array}{l}\text { Lodo de } \mathrm{PACl} \\
(\mathrm{ST}=0,21 \%)\end{array}$ & $\begin{array}{l}\text { Lodo de PACl } \\
(\mathrm{ST}=0,28 \%)\end{array}$ \\
\hline 0 & 4,2 & 2,7 & 0,21 & 0,28 \\
\hline 1dia & 14,5 & 18,3 & *esturricou & *esturricou \\
\hline 2 dias & 20,5 & 25,2 & *esturricou & *esturricou \\
\hline 3 dias & 25,3 & $39,8 * *$ & *esturricou & *esturricou \\
\hline 4 dias & $38,5 * *$ & 35,4 & *esturricou & *esturricou \\
\hline 5 dias & 33,3 & 38,2 & *esturricou & *esturricou \\
\hline 6 dias & 28,5 & 47,7 & *esturricou & *esturricou \\
\hline 7 dias & 42,3 & 50,3 & *esturricou & *esturricou \\
\hline
\end{tabular}

* Não foi possível coletar amostras pois sólidos "grudou" na manta.

** ocorrência de chuva.

A Figura 6.34 ilustra a variação de teor de sólidos para lodo de sulfato de alumínio entre dos Ensaios 5A e 5B.

O teor de sólidos inicial (1 dia) para o Ensaio 5A foi de ST $=18,3 \%$ enquanto para o Ensaio 5B, ST $=14,5 \%$. A velocidade de secagem foi maior para o lodo de menor teor de 
sólidos inicial na fase de drenagem $(\mathrm{ST}=2,7 \%)$ que para lodo com maior teor de sólido $(\mathrm{ST}=$ 4,2\%). Contudo, o valor final de teor de sólidos apresentou valores próximos, cerca de $\mathrm{ST}=$ $50,3 \%$ para o Ensaio $5 \mathrm{~A}$ e $\mathrm{ST}=42 \%$ para o Ensaio $5 \mathrm{~B}$.

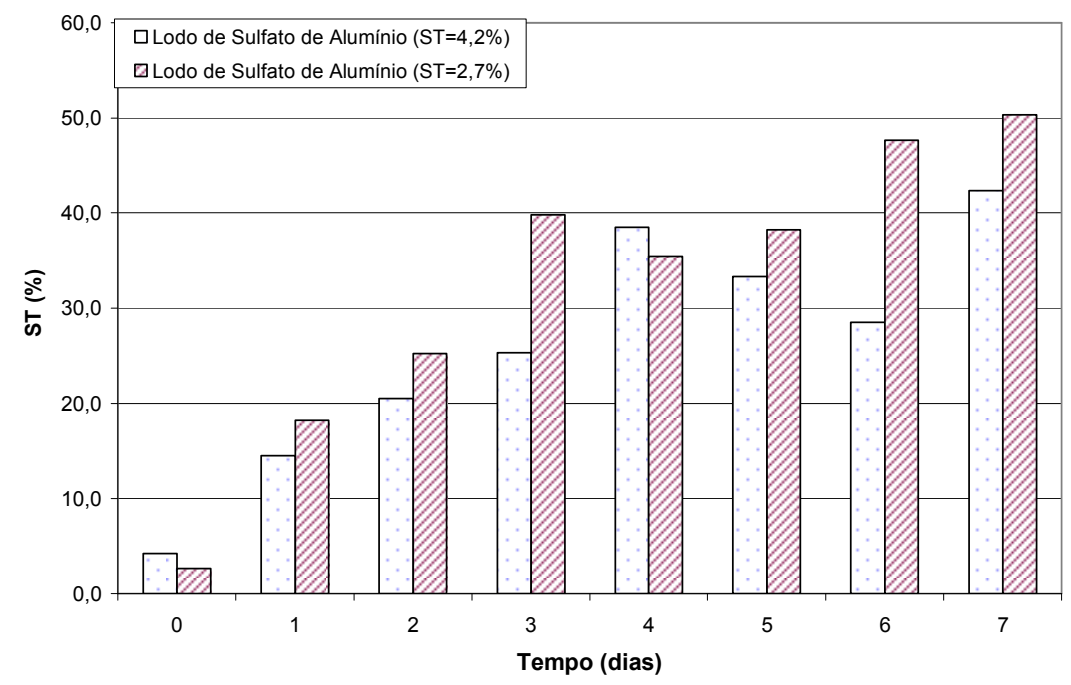

Figura 6.34 - Variação do teor de sólidos de resíduo de Sulfato de Alumínio retido na manta do leito de drenagem, Ensaios 5A e 5B. 


\subsection{Avaliação conjunta de desempenho dos ensaios de desaguamento com lodo de sulfato de alumínio e de PAC $\ell$ por Leito de Drenagem.}

Na seção 6.3 apresenta-se a discussão dos resultados relativos à avaliação conjunta dos ensaios realizados e apresentados anteriormente na seção 6.2.

Na seção 6.3.1 apresenta-se o resumo geral dos resultados das variáveis operacionais e de controle dos ensaios de desaguamento por Leito de drenagem, bem como as particularidades relativas aos diferentes lodos de sulfato de alumínio e de cloreto de polialumínio $(\mathrm{PAC \ell})$.

Nos itens subseqüentes são feitas avaliações conjuntas baseado no estudo das propriedades dos lodos. As macropropriedades são avaliadas a partir da análise das curvas de sedimentação, item 6.3.2, e das características de desaguamento por sistemas naturais, particularmente com uso de leito de drenagem em que compreende a Fase de Drenagem, item 6.3.3 e Fase de Secagem, item 6.3.4.

A avaliação das características intrínsecas dos lodos relacionadas com as micropropriedades e das propriedades das mantas geotexteis usadas nos ensaios estão contidas no item 6.3.5.

$\mathrm{Na}$ seção 6.3.6 são apresentadas discussões sobre as fundamentações teóricas e compreensão dos mecanismos relacionados com desaguamento de lodos de ETAs através de Leito de Drenagem.

\subsubsection{Desempenho dos ensaios de desaguamento por Leito de Drenagem com as amostras de lodos de sulfato de alumínio e lodos de $\mathrm{PACl}$.}

Na Tabela 6.19 é apresentado o resumo geral dos resultados das condições iniciais de ensaio e das variáveis operacionais e de controle apresentados, anteriormente na seção 6.2. 
Tabela 6.19 - Resumo geral das condições de ensaio e resultados dos ensaios de desaguamento de resíduos de ETA.

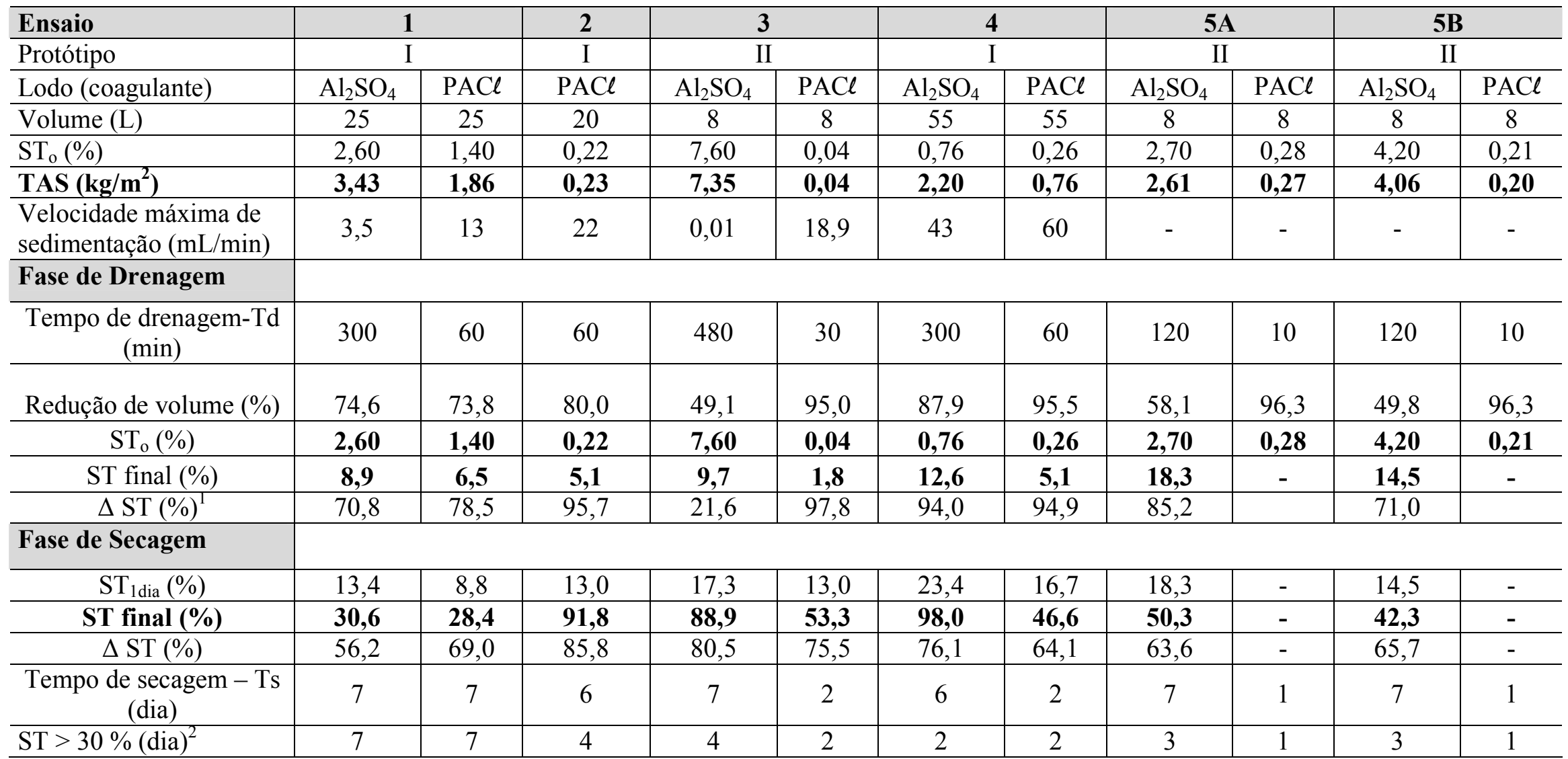

(1) - Variação de teor de sólidos $\Delta \mathrm{ST}(\%)=\left[\mathrm{ST}_{\mathrm{o}}(\%) / \mathrm{ST} \text { final }(\%)\right]^{*} 100$;

(2) - Tempo em dias em que teor de sólidos (ST \%) de lodo desaguado maior que $30 \%$. 
Para todas as diferentes condições de desaguamento, em que pese as diferentes teores de sólidos e volumes aplicados das amostras de lodo de sulfato de alumínio e de PACl, o tempo de drenagem máximo foi de aproximadamente 8 horas para os lodos de sulfato de alumínio e 60 minutos ou 1 hora para os lodos de PACl.

A redução de volume de lodo na fase de drenagem foi superior a aproximadamente 50 \% para lodos de sulfato de alumínio e acima de $74 \%$ para os lodos de PACl.

Os teores de sólidos ao final dos ensaios de desaguamento ( 7 dias) foram para todos os casos, acima de $28,4 \%$, quando houve considerável ocorrência de chuva e acima de $45 \%$ para quando não houve chuva (precipitação acima de $5 \mathrm{~mm}$ ).

\subsubsection{Velocidade de Sedimentação}

Na seção 6.3.2 são apresentados os resultados dos ensaios de coluna de sedimentação e a discussão das características de sedimentabilidade das amostras de lodos submetidas aos ensaios de desaguamento por leito de drenagem. O fenômeno da sedimentação assume grande importância durante a fase de drenagem dos ensaios de desaguamento, pois relaciona-se com o fluxo de sólidos incidente a superfícies da manta geotêxtil e também com a formação de camada filtrante composta pelo rearranjo das partículas sólidas da massa de lodo.

A Figura 6.35 apresenta os resultados dos ensaios de coluna de sedimentação para os lodos de sulfato de alumínio e PACl, construída a partir da Tabela A.5, Anexo A. Na realização dos ensaios 5A e 5B não foi possível realizar os ensaios de sedimentação por insuficiência de volume de amostras. 

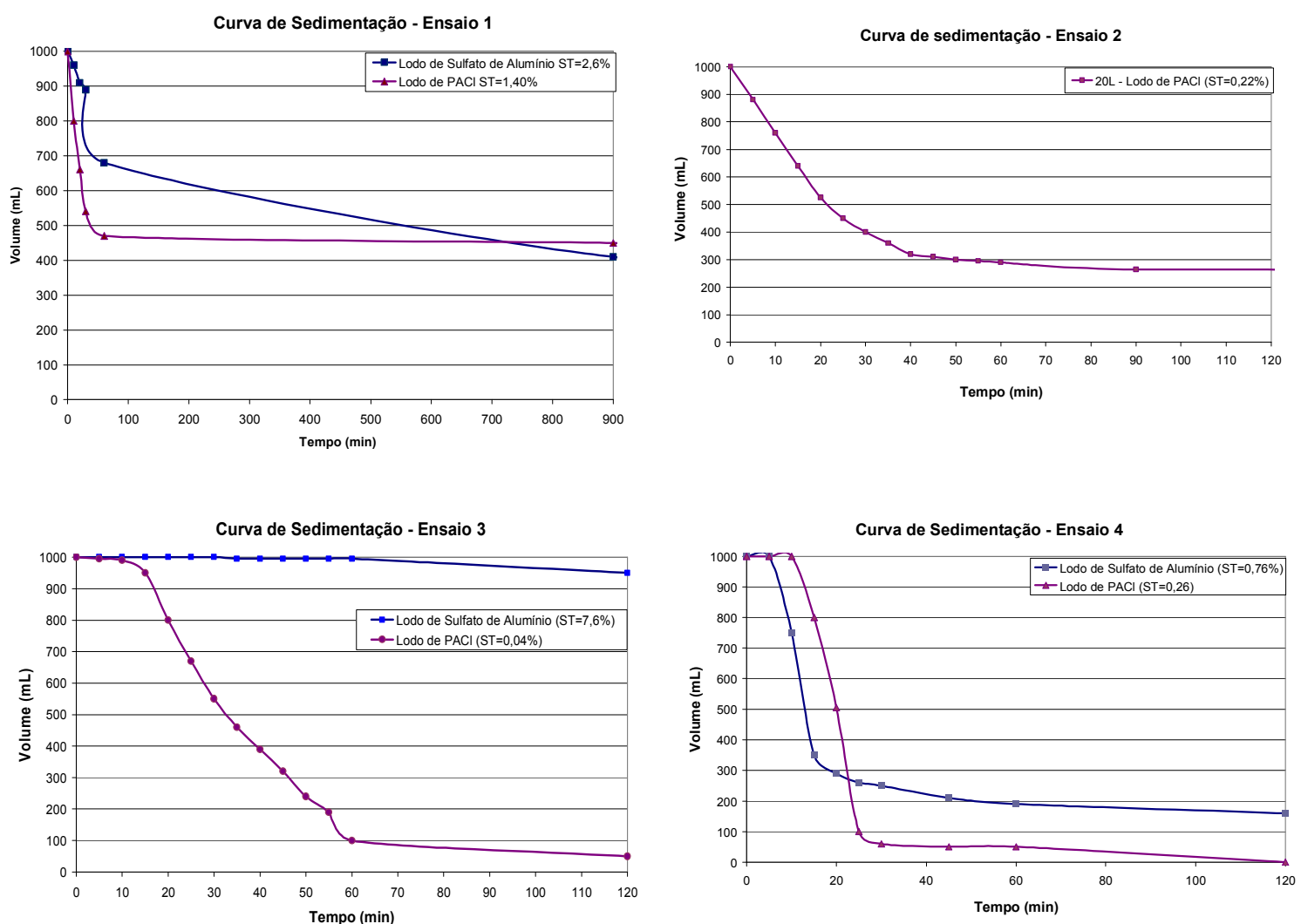

Figura 6.35 - Curvas de sedimentação das amostras de lodos de ETAs de sulfato de alumínio e de PACl usadas nos Ensaios 1, 2, 3 e 4 de desaguamento através de leito de drenagem.

$\mathrm{Na}$ Figura 6.35, as curvas de sedimentação mostram que os lodos de sulfato de alumínio sedimentaram com menor velocidade que os lodos de PACl.

A Tabela 6.20 apresenta um quadro geral dos resultados obtidos dos ensaios de sedimentação, em que consta, as amostras de lodo de sulfato de alumínio e de $\mathrm{PACl}$ usadas nos ensaios de desaguamento, o teor de sólidos inicial, $\mathrm{ST}_{\mathrm{o}}(\%)$, e correspondente velocidade de sedimentação máxima, (Vs). 
Tabela 6.20 - Quadro geral das velocidades de sedimentação das amostras usadas nos Ensaios $1,2,3$ e 4 .

\begin{tabular}{|c|c|c|}
\hline Ensaio & Amostras $-\left(\mathrm{ST}_{\mathbf{0}}=\%\right)$ & Velocidade de sedimentação - Vs $(\mathrm{cm} / \mathrm{min})$ \\
\hline \multirow{2}{*}{1} & Sulfato de alumínio $\left(\mathrm{ST}_{0}=2,6 \%\right)$ & 0,21 \\
\hline & $\mathrm{PACl}\left(\mathrm{ST}_{0}=1,4 \%\right)$ & 0,78 \\
\hline 2 & $\mathrm{PACl}\left(\mathrm{ST}_{\mathrm{o}}=0,22 \%\right)$ & 1,4 \\
\hline \multirow{2}{*}{3} & Sulfato de alumínio $\left(\mathrm{ST}_{0}=7,6 \%\right)$ & 0,05 \\
\hline & $\mathrm{PACl}\left(\mathrm{ST}_{0}=0,04 \%\right)$ & 1,1 \\
\hline \multirow{2}{*}{4} & Sulfato de alumínio $\left(\mathrm{ST}_{0}=0,8 \%\right)$ & 2,6 \\
\hline & $\mathrm{PACl}\left(\mathrm{ST}_{0}=0,26 \%\right)$ & 3,6 \\
\hline
\end{tabular}

Em geral, os lodos de $\mathrm{PACl}$ apresentaram velocidades de sedimentação máxima acima de $0,78 \mathrm{~cm} / \mathrm{min}$, valores estes mais elevados que os lodos de sulfato de alumínio, com valor máximo de $0,21 \mathrm{~cm} / \mathrm{min}$. O Ensaio 4 foi exceção pois apresentou uma abrupta queda da interface até o tempo de 15 minutos.

Os resultados e comportamentos entre os Ensaios 2 e 4 para o lodo $\mathrm{PACl}$ apresentaram comportamentos distintos, embora tenham valores aproximados de ST (\%), em torno de 0,22 e $0,26 \%$. A velocidade de sedimentação máxima da amostra de lodo de PACl do Ensaio 4 $(\mathbf{V s}=\mathbf{3 , 6} \mathbf{~ c m} / \mathbf{m i n})$ foi três vezes mais elevada que a do Ensaio $2(\mathbf{V s}=\mathbf{1 , 4} \mathbf{~ c m} / \mathbf{m i n})$. Após 60 minutos de ensaio os valores foram de $190 \mathrm{~mL}$ de volume de lodo sedimentado para a amostra de lodo de PACl do Ensaio 4 e cerca de $290 \mathrm{~mL}$ para Ensaio 2.

A partir dos resultados ilustrados na Figura 6.35, constatou-se a tendência de quanto maior o teor de sólidos menor a velocidade máxima de sedimentação. Os resultados obtidos para o lodo de $\mathrm{PACl}$ não apresentam regularidade nessa tendência 
Os resultados obtidos para os Ensaios 1, 2 e 4 apresentaram comportamento semelhante à curva de sedimentação do tipo sazonal, conforme relatado no Capítulo 4, seção 4.4.3.2.

De maneira geral, no instante inicial $\mathrm{T}_{\mathrm{o}}$, o lodo esteve presente em toda altura $\mathrm{H}$. $\grave{A}$ medida que o lodo sedimentou houve aumento da concentração de sólidos nas camadas inferiores e conseguinte redução da velocidade de sedimentação até tornar-se nula.

Porém, para o caso do Ensaio 4, especialmente para o lodo de $\mathrm{PACl}$, encontrou-se dificuldade na identificação visual da interface liquído-clarificado-lodo.

\subsubsection{Avaliação do desaguamento por Leito de Drenagem - Fase de Drenagem}

Na seção 6.3.3 discutem-se os resultados referentes à variação de vazão de drenagem, a variação de volume acumulado de água livre drenada em relação ao volume aplicado, e as características da água drenada quanto à turbidez, cor, sólidos totais, pH e metais.

\subsubsection{Variação da vazão de drenagem de água livre}

Os valores de vazão de drenagem são determinantes para o desempenho do desaguamento. Naturalmente buscam-se as vazões mais elevadas, de maneira a minorar o volume e tempo necessário ao desaguamento, destacadamente, na fase de drenagem. Procurou-se aqui discutir os aspectos que regem a drenagem de água livre dos lodos de ETAs com o tempo, baseado nos resultados obtidos com os ensaios de desaguamento.

Conforme já reportado na seção 6.4.1, durante a fase de drenagem, o tempo máximo necessário (tempo de drenagem) foi de 8 horas para os lodos de sulfato de alumínio e de 1 hora para os lodos de PACl. Além disso, a redução de volume de lodo na fase de drenagem foi sempre superior a $50 \%$ para lodos de sulfato de alumínio e acima de $74 \%$ para os lodos de PACl. Ressalta-se que os ensaios foram realizados para altura máxima de $20 \mathrm{~cm}$. 
Estes resultados supracitados já indicam o bom desempenho do leito de drenagem na fase de drenagem, porém algumas considerações específicas devem ser reportadas.

Na Figura 6.36 apresenta-se um resumo geral dos resultados de variação de vazão de drenagem para os Ensaios 1, 2, 3, 4, 5A e 5B.
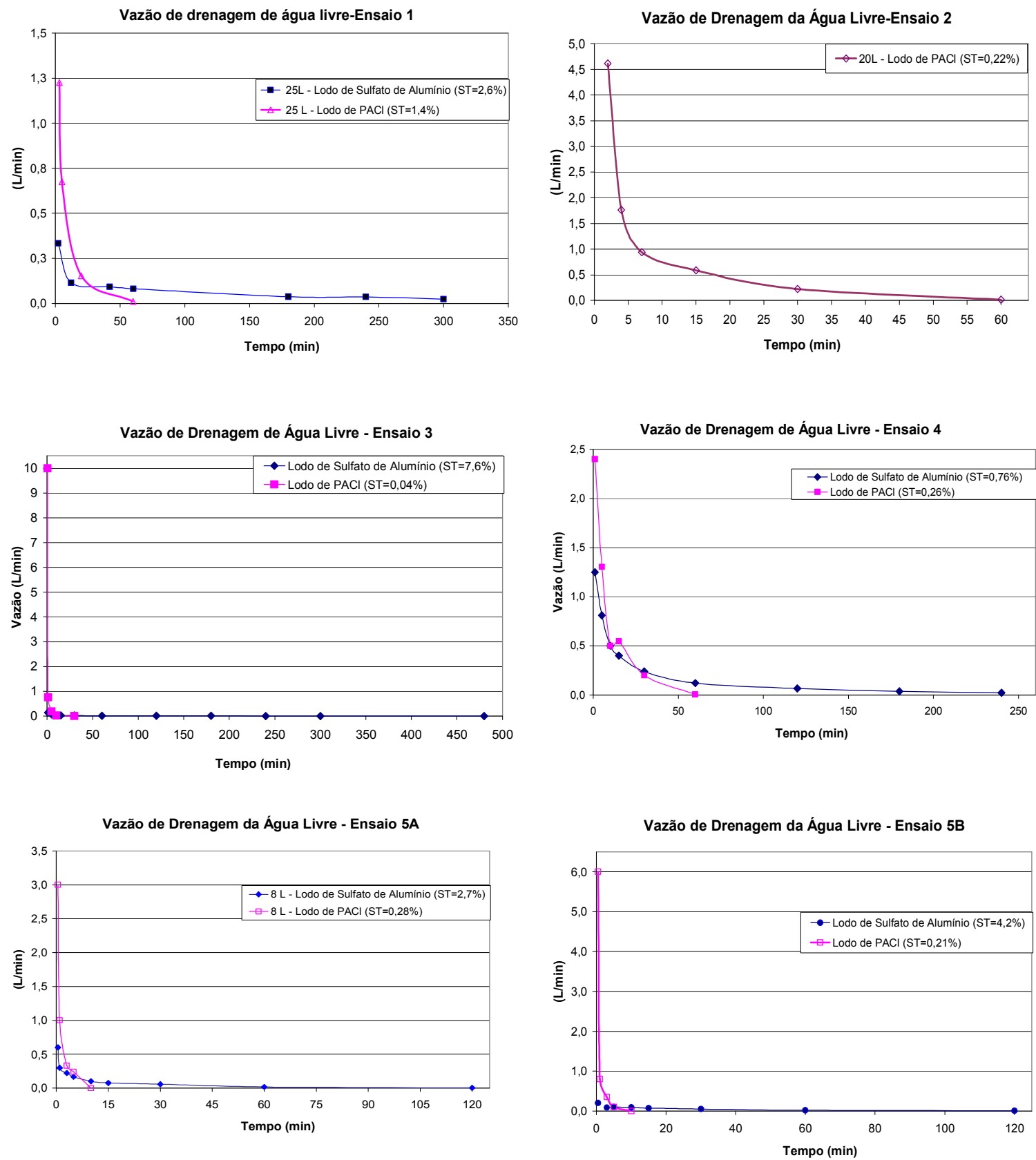

Figura 6.36 - Variação da vazão de drenagem para os Ensaios 1, 2, 3, 4, 5A e 5B. 
$\mathrm{Na}$ comparação dos resultados entre Ensaios 2 e 4 para o lodo de PACl, em que os lodos possuem teor de sólidos em torno de $\mathrm{ST}=0,20 \%$, o tempo de drenagem foi $\mathrm{Td}=60$ minutos para ambos. Porém, a vazão inicial $\mathrm{Q}=4,62 \mathrm{~L} / \mathrm{min}$ no Ensaio $2(20 \mathrm{~L}, \mathrm{ST}=0,22 \%$, TAS $\left.=0,23 \mathrm{~kg} / \mathrm{m}^{2}\right)$ é o dobro da vazão inicial $\mathrm{Q}=2,4 \mathrm{~L} / \mathrm{min}$ do Ensaio $4(55 \mathrm{~L}, \mathrm{ST}=0,26 \%$, TAS $=0,76 \mathrm{~kg} / \mathrm{m}^{2}$ ), mas após 30 minutos as vazões igualam-se.

Interessante lembrar que nos ensaios de sedimentação, a velocidade de sedimentação

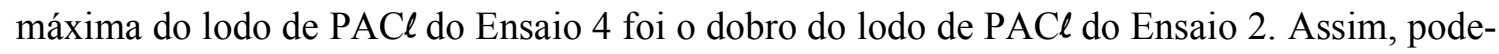
se inferir que a rápida sedimentação das partículas do Ensaio 4 podem ter conferido maior dificuldade na drenagem da água livre.

Os Ensaios 5A e 5B foram realizados sob as mesmas condições de volume de aplicação de amostra (altura de lodo) e mesmo lodo de origem. Contudo, o lodo de PAC $\ell$ de menor teor de sólidos $(\mathrm{ST}=0,21 \%)$ apresentou valor da vazão inicial $\mathrm{Q}=6,0 \mathrm{~L} / \mathrm{min}$ aproximadamente duas vezes mais elevada que a vazão inicial $\mathrm{Q}=3,0 \mathrm{~L} / \mathrm{min}$ do lodo de PACl de maior teor de sólidos $(\mathrm{ST}=0,28 \%)$.

Apresentam-se os valores de vazão de drenagem inicial (ordem decrescente) e correspondente Taxa de aplicação de sólidos $\left(\mathrm{kg} / \mathrm{m}^{2}\right)$ para todos os ensaios realizados com amostras de lodo de sulfato de alumínio e de PACl.

A Tabela 6.21 mostra os resultados de vazão de drenagem inicial e taxa de aplicação de sólidos para as amostras de lodo de sulfato de alumínio e a Tabela 6.22 os resultados para as amostras de lodo de PACl. 
Tabela 6.21 - Valores de vazão de drenagem em ordem decrescente para os lodos de sulfato de alumínio e correspondente taxa de aplicação de sólidos.

\begin{tabular}{c|c|c}
\hline $\begin{array}{c}\text { Vazão de drenagem inicial } \\
(\mathbf{L} / \mathbf{m i n})\end{array}$ & $\begin{array}{c}\text { Taxa de aplicação de sólidos } \\
\text { TAS }\left(\mathbf{k g} / \mathbf{m}^{\mathbf{2}}\right)\end{array}$ & $\begin{array}{c}\text { Ensaio } \\
\text { (Volume em L) }\end{array}$ \\
\hline 1,25 & 2,20 & Ensaio 4 (55 L) \\
\hline 0,60 & 2,61 & Ensaio 5A (8 L) \\
\hline 0,33 & 3,46 & Ensaio 1 (25 L) \\
\hline 0,20 & 4,06 & Ensaio 5B (8 L) \\
\hline 0,15 & 7,35 & Ensaio 3 (8 L) \\
\hline
\end{tabular}

Tabela 6.22 - Valores de vazão de drenagem em ordem decrescente para os lodos de PACl e correspondente taxa de aplicação de sólidos.

\begin{tabular}{c|c|c}
\hline $\begin{array}{c}\text { Vazão de drenagem inicial } \\
(\mathbf{L} / \mathbf{m i n})\end{array}$ & $\begin{array}{c}\text { Taxa de aplicação de sólidos } \\
\text { TAS }\left(\mathbf{k g} / \mathbf{m}^{2}\right)\end{array}$ & $\begin{array}{c}\text { Ensaio } \\
(\text { Volume em L) }\end{array}$ \\
\hline 10,0 & 0,04 & Ensaio 3 (8 L) \\
\hline 6,0 & 0,20 & Ensaio 5B (8 L) \\
\hline 4,6 & 0,23 & Ensaio 2 (20) \\
\hline 3,0 & 0,27 & Ensaio 5A (8 L) \\
\hline 1,2 & 0,76 & Ensaio 4 (55 L) \\
\hline
\end{tabular}

Para todos os ensaios realizados o maior valor de vazão de drenagem foi de $10 \mathrm{~L} / \mathrm{min}$ para o lodo de $\mathrm{PACl}$, com menor valor de $\mathrm{TAS}=0,04 \mathrm{~kg} / \mathrm{m}^{2}$ e a menor vazão de drenagem foi de $0,145 \mathrm{~L} / \mathrm{min}$ para o lodo de sulfato de alumínio, com TAS $=7,35 \mathrm{~kg} / \mathrm{m}^{2}$, ambos pertencentes as amostras do Ensaio 3 (representativo de situações extremas). 
Apesar da peculiaridade do Ensaio 3, essa tendência foi observada nos demais ensaios. O valor da vazão de drenagem de água livre foi maior quanto menor o valor de TAS ou ST (\%) independente do volume aplicado (altura de lodo) ou tipo de leito de drenagem (Leito de Drenagem I ou II).

A Figura 6.37 foi construída a partir dos valores constantes nas Tabelas 6.22 e 6.23 e ilustra a relação entre a vazão de drenagem inicial e a taxa de aplicação de sólidos (TAS) para os lodos de sulfato de alumínio e PACl.

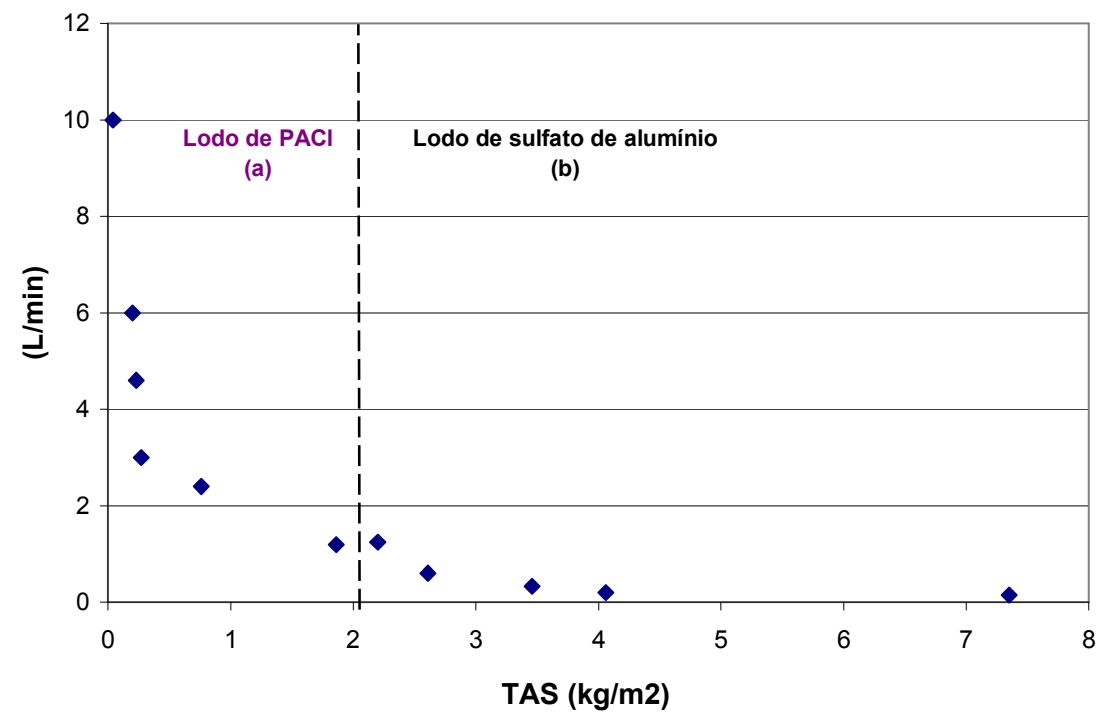

Figura 6.37 - Relação entre vazão de drenagem inicial de água livre em (L/min) e valores de taxa de aplicação de sólidos-TAS em $\left(\mathrm{kg} / \mathrm{m}^{2}\right)$ para os diferentes ensaios realizados com as amostras de lodo de $\mathrm{PACl}$ (a) e de sulfato de alumínio (b).

A partir da Figura 6.37 torna-se evidente que a vazão de drenagem apresentou-se mais elevada para os lodos de $\mathrm{PAC} \ell$ que para sulfato de alumínio.

Além disso, a distribuição dos pontos confirmou a existência de relação inversa entre velocidade de drenagem e TAS para os dois tipos de lodos. O comportamento da curva mostra a continuidade da tendência nos lodos de $\mathrm{PACl}$, com maiores valores de vazão de drenagem, para os lodos de sulfato de alumínio com menor valor de vazão de drenagem. 
Portanto, pode-se inferir que a vazão de drenagem foi maior quanto menor a taxa de aplicação de sólidos - TAS $\left(\mathrm{kg} / \mathrm{m}^{2}\right)$ e indiretamente o teor de sólidos (ST\%).

Vale lembrar, que o teor de sólidos e mais precisamente a taxa de aplicação de sólidos remonta à fração volumétrica de partículas do lodo e como tal, influencia nas caracteristicas reológicas do lodo, seja a viscosidade, tensão limite de cisalhamento entre outros fatores determinantes para a estabilização das suspensões ou para velocidade de sedimentação das partículas/flocos.

Dessa forma, pode-se concluir que no desaguamento de lodos de ETAs (sulfato de alumínio e de $\mathrm{PACl}$ ), a vazão de drenagem está mais relacionada com a taxa de aplicação de sólidos - TAS $\left(\mathrm{kg} / \mathrm{m}^{2}\right)$ e/ou teor de sólidos ST (\%) que com a magnitude do volume de lodo aplicado.

Esses aspectos discutidos mostram-se importantes para quando seja necessária uma prévia avaliação de alternativas de emprego de coagulantes em conjunto com estudos de desaguamento de lodos de ETAs.

Todavia, na Fase de drenagem objetiva-se não só atender os requisitos quantitativos, mas também os aspectos qualitativos concernentes à qualidade da água livre drenada. Assim, na próxima seção será realizada a discussão das características da água livre drenada que passa através do leito de drenagem conjuntamente com a variação do volume acumulado com o tempo.

\subsubsection{Variação do volume acumulado e características da água livre drenada}

No capitulo 6, seção 6.2, foram apresentados para cada ensaio de desaguamento realizado, os resultados referentes ao percentual de volume acumulado de água drenada com o tempo, e os valores de turbidez destas frações de volume. Na seção 6.3.3.2 amplia-se essa abordagem ao alcance das demais variáveis que caracterizaram a água livre drenada. 
Na Figura 6.38 estão agrupados os resultados de volume acumulado para os lodos de sulfato de alumínio.

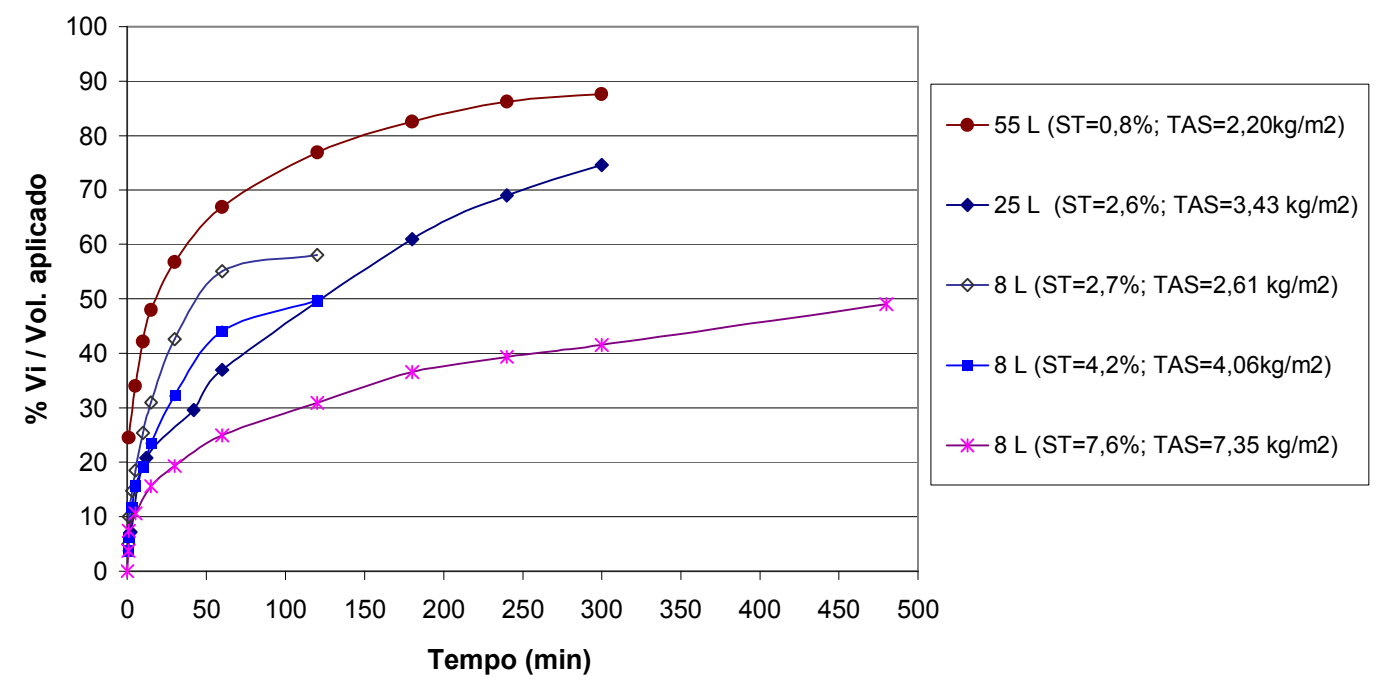

Figura 6.38 - Volume acumulado de água livre drenada dos ensaios de desaguamento com as amostras de lodo de sulfato de alumínio.

Os resultados ilustrados na Figura 6.38 mostraram que, quanto menor foi o teor de sólidos das amostras de lodo de sulfato de alumínio, maior a porcentagem final de volume acumulado de água livre drenada. O menor valor final de volume acumulado de água livre drenado foi de cerca de $50 \%$ para o ensaio com amostra de lodo de maior concentração de teor de sólidos.

Na Figura 6.39 estão agrupados os resultados de volume acumulado para os lodos de PACl. 


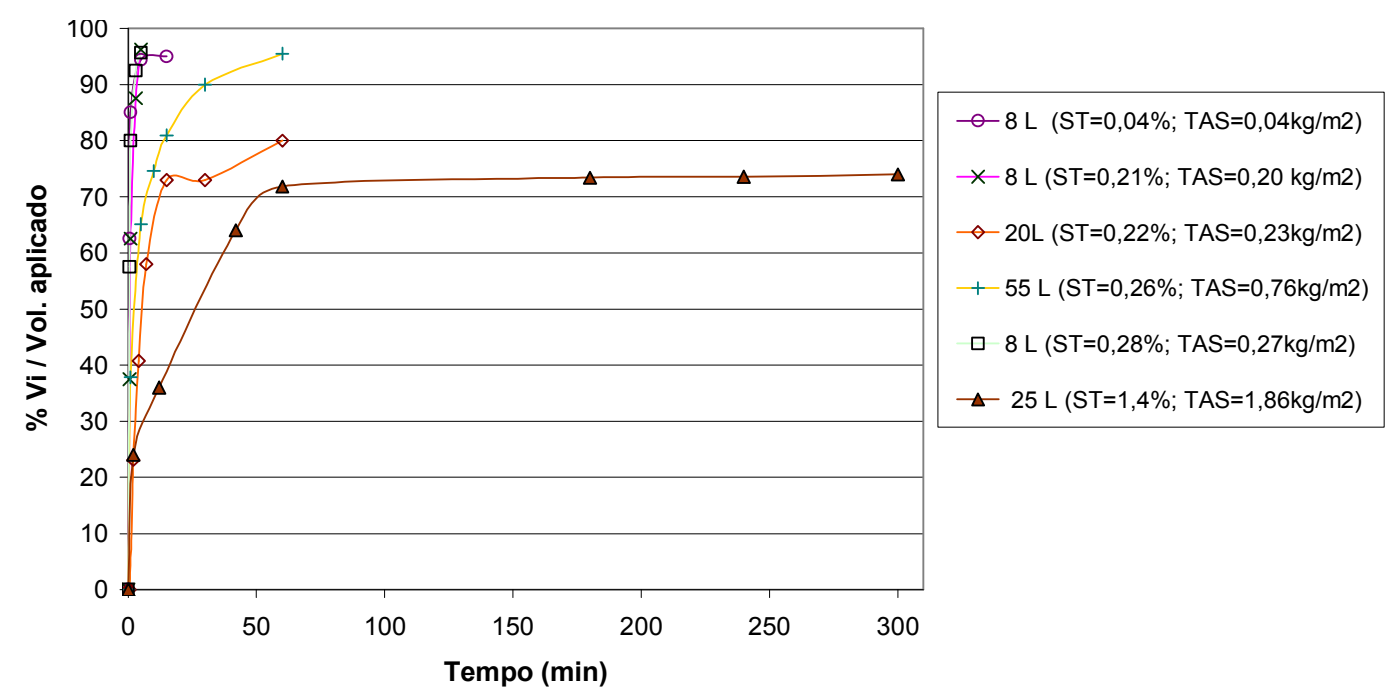

Figura 6.39 - Volume acumulado de água livre drenada dos ensaios de desaguamento com as amostras de lodo de PACl.

Para os lodos de $\mathrm{PACl}$ também foi observada ligeira tendência de quanto menor o teor de sólidos, maior a percentagem final de volume acumulado de água livre drenada. O menor valor final de volume acumulado ficou acima de $70 \%$, para o lodo de $\mathrm{PACl}$ com maior valor de teor de sólidos $(\mathrm{ST}=1,4 \%)$.

A partir dos resultados obtidos de volume acumulado para os lodos de sulfato de alumínio e de $\mathrm{PAC} \ell$ houve indicações de que, o volume acumulado final de água drenada possuiu relação inversa com o teor de sólidos das amostras de lodos submetidas aos ensaios de desaguamento nos Leitos de Drenagem I e II.

Na Figura 6.40 são apresentados os resultados de volume acumulado separados para cada ensaio. Mais uma vez, observa-se que os lodos de $\mathrm{PACl}$, caracterizados por baixos valores de teor de sólidos e taxa de aplicação de sólidos apresentam maior percentagem de volume acumulado em um menor intervalo de tempo que os lodos de sulfato de alumínio. 

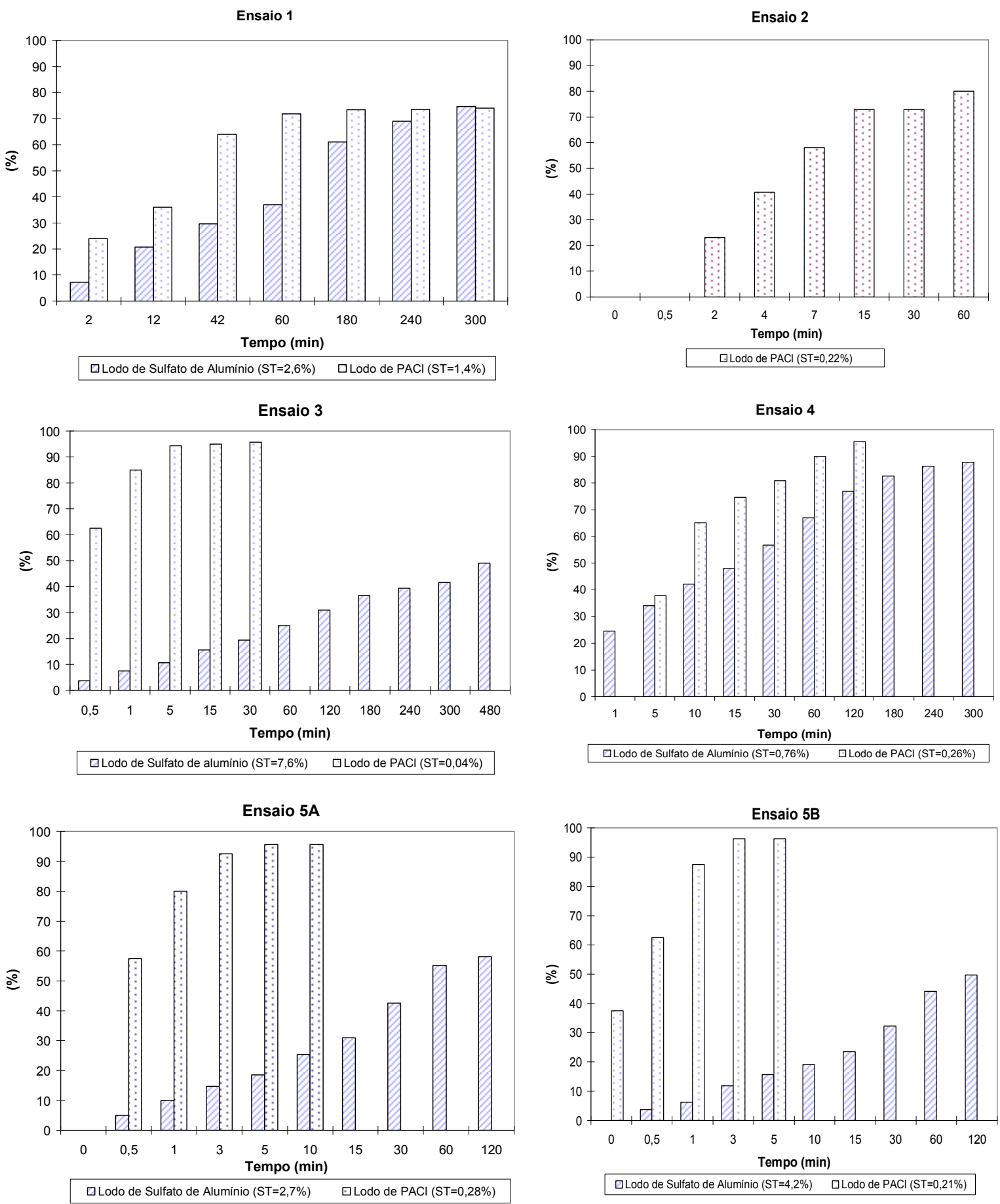

Figura 6.40 - Relação entre volume acumulado de água livre drenada e volume aplicado em (\%) para cada ensaio de desaguamento com amostras de lodo de sulfato de alumínio e de PACl, Ensaios 1, 2, 3, 4, 5A e 5B.

Os resultados mostrados na Figura 6.40 relativos ao volume acumulado de água livre drenada para cada ensaio e os resultados de caracterização da água livre drenada podem 
subsidiar a avaliação qualitativa da Fase de drenagem e mais particularmente da água livre drenada.

\subsubsection{Valores de turbidez, cor e pH na água livre drenada}

Nesta seção 6.3.3.3 são apresentados os resultados dos valores de turbidez, cor e pH na água drenada, conforme mostra a Tabela 6.23.

Tabela 6.23 - Valores de cor aparente (uC), turbidez (uT) e pH nas amostras de água drenada dos ensaios de desaguamento realizados.

\begin{tabular}{|c|c|c|c|c|c|c|}
\hline \multicolumn{7}{|l|}{ Ensaio 1} \\
\hline Tempo & \multicolumn{2}{|c|}{ Cor aparente (uC) } & \multicolumn{2}{|c|}{ Turbidez (uT) } & \multicolumn{2}{|c|}{ pH } \\
\hline$(\min )$ & $\begin{array}{l}\text { Sulfato de } \\
\text { alumínio }\end{array}$ & $\mathrm{PACl}$ & $\begin{array}{c}\text { Sulfato de } \\
\text { alumínio }\end{array}$ & $\mathrm{PACl}$ & $\begin{array}{l}\text { Sulfato de } \\
\text { alumínio }\end{array}$ & $\mathrm{PACl}$ \\
\hline 2 & 984 & 118 & 135 & 29,3 & 6,4 & 6,6 \\
\hline 10 & 608 & 3 & 69 & 1,8 & 6,3 & 6,3 \\
\hline 60 & 57 & 4 & 4,8 & 1,1 & 7,0 & 6,8 \\
\hline \multicolumn{7}{|l|}{ Ensaio 2} \\
\hline Tempo & \multicolumn{2}{|c|}{ Cor aparente (uC) } & \multicolumn{2}{|c|}{ Turbidez (uT) } & \multicolumn{2}{|c|}{ pH } \\
\hline$(\min )$ & - & $\mathrm{PACl}$ & - & $\mathrm{PACl}$ & - & $\mathrm{PACl}$ \\
\hline 0,5 & - & 74 & - & 17,3 & - & 7 \\
\hline 2 & - & 26 & - & 2,4 & - & 6,8 \\
\hline 4 & - & 5 & - & 1,1 & - & 6,9 \\
\hline 7 & - & 14 & - & 1,3 & - & 6,6 \\
\hline 15 & - & 13 & - & 2,1 & - & 6,4 \\
\hline 30 & - & 22 & - & 1,1 & - & 6,3 \\
\hline \multicolumn{7}{|l|}{ Ensaio 3} \\
\hline Tempo & \multicolumn{2}{|c|}{ Cor aparente (uC) } & \multicolumn{2}{|c|}{ Turbidez (uT) } & \multicolumn{2}{|l|}{ pH } \\
\hline$(\min )$ & $\begin{array}{l}\text { Sulfato de } \\
\text { alumínio }\end{array}$ & $\mathrm{PACl}$ & $\begin{array}{c}\text { Sulfato de } \\
\text { alumínio }\end{array}$ & $\mathrm{PACl}$ & $\begin{array}{l}\text { Sulfato de } \\
\text { alumínio }\end{array}$ & $\mathrm{PACl}$ \\
\hline 0,5 & $>\mathrm{ND}$ & $>\mathrm{ND}$ & 0 & 362 & - & - \\
\hline 1 & $>\mathrm{ND}$ & 43 & 136 & 15,5 & 6,6 & 6,7 \\
\hline 5 & $>\mathrm{ND}$ & 2 & 70,4 & 0,8 & 7,2 & 6,8 \\
\hline 10 & - & 2 & - & 0,8 & - & 6,5 \\
\hline 15 & 332 & - & 21,9 & - & 7,2 & 6,7 \\
\hline 30 & 135 & - & 7,5 & - & 7,7 & - \\
\hline 60 & 55 & & 1,2 & - & 7,5 & - \\
\hline 120 & 35 & - & 1,6 & - & 7,8 & - \\
\hline 180 & 28 & - & 0,7 & - & 7,8 & - \\
\hline 240 & 25 & - & 0,5 & - & 7,7 & - \\
\hline
\end{tabular}




\begin{tabular}{|c|c|c|c|c|c|c|}
\hline \multicolumn{7}{|l|}{ Ensaio 4} \\
\hline Tempo & \multicolumn{2}{|c|}{ Cor aparente (uC) } & \multicolumn{2}{|c|}{ Turbidez (uT) } & \multicolumn{2}{|c|}{ pH } \\
\hline$(\min )$ & $\begin{array}{c}\text { Sulfato de } \\
\text { alumínio }\end{array}$ & $\mathrm{PACl}$ & $\begin{array}{l}\text { Sulfato de } \\
\text { alumínio }\end{array}$ & $\mathrm{PACl}$ & $\begin{array}{l}\text { Sulfato de } \\
\text { alumínio }\end{array}$ & $\mathrm{PACl}$ \\
\hline 1 & 387 & ND & 60 & 213 & 7,1 & 7,1 \\
\hline 5 & 209 & 9 & 16,7 & 1,9 & 7,2 & 7,2 \\
\hline 15 & 159 & 8 & 11,3 & 1,2 & 6,9 & 7,1 \\
\hline 30 & 102 & 7 & 6,8 & 0,7 & 7 & 7 \\
\hline 60 & 35 & 4 & 3,4 & 1 & 7,1 & 7,4 \\
\hline \multicolumn{7}{|l|}{ Ensaio 5A } \\
\hline Tempo & \multicolumn{2}{|c|}{ Cor aparente (uC) } & \multicolumn{2}{|c|}{ Turbidez (uT) } & \multicolumn{2}{|c|}{$\mathbf{p H}$} \\
\hline$(\min )$ & $\begin{array}{l}\text { Sulfato de } \\
\text { alumínio }\end{array}$ & $\mathrm{PACl}$ & $\begin{array}{l}\text { Sulfato de } \\
\text { alumínio }\end{array}$ & $\mathrm{PACl}$ & $\begin{array}{l}\text { Sulfato de } \\
\text { alumínio }\end{array}$ & $\mathrm{PACl}$ \\
\hline 0,5 & $>$ faixa & 519 & 329 & 137 & & 7,1 \\
\hline 1 & $>$ faixa & 114 & 125 & 25,6 & 6,6 & 7,2 \\
\hline 3 & $>$ faixa & 34 & 45 & 5,6 & & \\
\hline 5 & 497 & 31 & 31,5 & 4,9 & 7,2 & 7,1 \\
\hline 10 & 444 & - & 29,5 & - & - & - \\
\hline 15 & 310 & - & 17,1 & - & 7,2 & - \\
\hline 30 & 178 & - & 3,3 & - & 7,7 & - \\
\hline 60 & 56 & - & 2,4 & - & 7,5 & - \\
\hline \multicolumn{7}{|l|}{ Ensaio 5B } \\
\hline Tempo & \multicolumn{2}{|c|}{ Cor aparente (uC) } & \multicolumn{2}{|c|}{ Turbidez (uT) } & \multicolumn{2}{|l|}{ pH } \\
\hline$(\min )$ & $\begin{array}{c}\text { Sulfato de } \\
\text { alumínio }\end{array}$ & $\mathrm{PACl}$ & $\begin{array}{l}\text { Sulfato de } \\
\text { alumínio }\end{array}$ & $\mathrm{PACl}$ & $\begin{array}{l}\text { Sulfato de } \\
\text { alumínio }\end{array}$ & $\mathrm{PACl}$ \\
\hline 0,5 & $>$ faixa & $>$ faixa & 155 & 588 & - & 7,0 \\
\hline 1 & $>$ faixa & 281 & - & 77 & 6,8 & 6,9 \\
\hline 3 & $>$ faixa & 29 & 66 & 8 & - & - \\
\hline 5 & 539 & 25 & 37,9 & 9,5 & 7,1 & 7,1 \\
\hline 10 & 424 & - & 28,9 & - & - & - \\
\hline 15 & 342 & - & 22,2 & - & 7 & - \\
\hline 30 & 188 & - & 7,7 & - & 7,6 & - \\
\hline 60 & 48 & - & 1,6 & - & 7,5 & - \\
\hline
\end{tabular}

ND - Não determinado, acima da faixa de leitura.

Os valores de $\mathrm{pH}$ nas amostras de água drenada de lodo de sulfato de alumínio, para os Ensaios 1, 3, 5A e 5B, elevaram-se com o tempo, com valores mínimo de 6,6 e máximo de 7,7. Para os lodos de PACl ocorreu mínima variação de pH, exceto Ensaio 2.

Os valores de cor e turbidez nas amostras de água drenada tiveram comportamentos semelhantes. De maneira geral, a água drenada dos lodos de sulfato de alumínio apresentaram baixos valores, comparado a água drenada dos lodos de $\mathrm{PACl}$. 
A cor e turbidez apresentaram valores mais elevados até os primeiros cinco minutos de ensaio (Ensaio 1, Ensaio 2, e Ensaio 4) para os dois tipos de lodos. Salienta-se que os volumes acumulados drenados nesse intervalo de tempo permaneceram abaixo de $50 \%$.

No Ensaio 2, após 4 minutos, a água drenada apresentou valores de turbidez menores que 2 uT e cor menores que 5 uC. Em seguida, os valores de cor elevaram-se acompanhados pela diminuição do valor de pH. A água drenada de aparência incolor assumiu coloração laranja.

Os resultados dos Ensaios 5A e 5B indicaram que os lodos de sulfato de alumínio e de $\mathrm{PACl}$ com maior teor de sólidos produzem água drenada com baixos valores de cor e turbidez.

A Figura 6.41 (a) mostra que a água livre drenada de lodo de sulfato de alumínio com $\mathrm{ST}=2,7 \%$ apresentou inicialmente valores de turbidez elevados, cerca de $330 \mathrm{uT}$, nos 30 segundos iniciais do ensaio. Os valores de turbidez para o lodo de sulfato de alumínio com ST $=2,7 \%$ é o dobro do apresentado por ST $=4,2 \%$ até o intervalo de 5 minutos, a partir do qual apresentam os mesmos valores de turbidez. O volume acumulado de água drenada nesse intervalo de tempo não ultrapassou os $20 \%$.

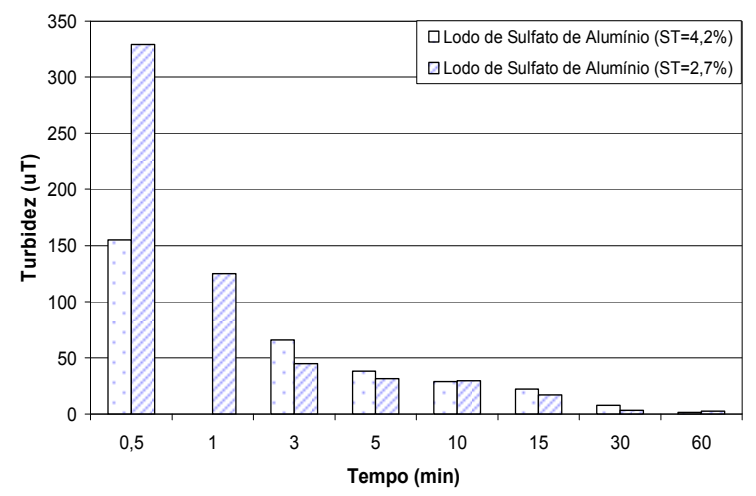

(a)

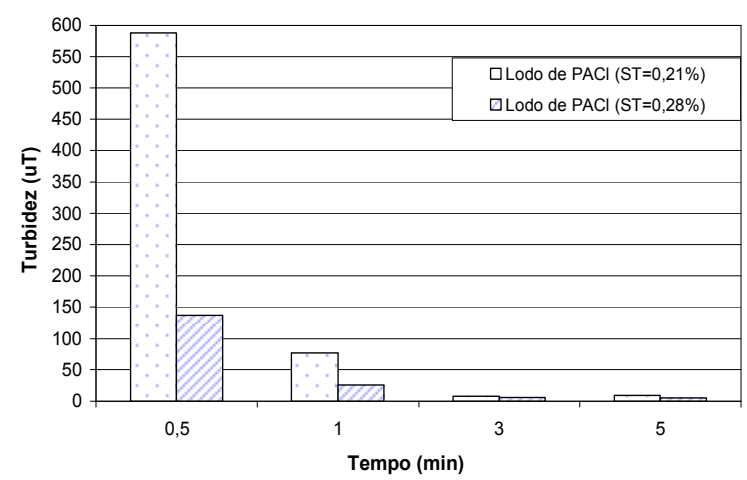

(b)

Figura 6.41 - Ilustração da variação dos valores de turbidez da água drenada de lodos de sulfato de alumínio (a) e lodos de $\mathrm{PACl}$ (b). 
A Figura 6.41 (b) mostra os valores de turbidez entre os dois lodos de PACl com os valores próximos de teor de sólidos, Ensaio 5A $(\mathrm{ST}=0,28 \%)$ e Ensaio 5B $(\mathrm{ST}=0,21 \%)$. Os valores de turbidez para o lodo do Ensaio 5B ( $\mathrm{ST}=0,21 \%)$ apresentaram-se mais elevados que os valores do lodo do Ensaio 5A ( $\mathrm{ST}=0,28 \%)$ no início do ensaio, para $\mathrm{t}=30$ segundos. Na seqüência, para $\mathrm{t}=1$ minuto, os valores de turbidez apresentaram valores muito próximos.

No caso dos lodos de $\mathrm{PACl}$, o volume acumulado de água drenada esteve acima de 70 \%. Isso torna-se importante pois pode ser determinante na definição de destino e aproveitamento da água drenada obtida após o desaguamento por Leito de Drenagem.

Deve-se frisar que os valores de turbidez, cor e $\mathrm{pH}$ encontrados nas amostras de água livre drenada apresentaram características semelhantes a mananciais usados no abastecimento de água das cidades brasileiras.

\subsubsection{Valores de concentração de sólidos na água drenada}

Na Tabela 6.24 são apresentados os valores de concentração de sólidos totais, fixos e voláteis totais em amostras coletadas dos Ensaios 1, 2 e 3. Os valores de sólidos totais são expressos em valores absolutos e sólidos fixos e voláteis em valores percentuais.

Tabela 6.24 - Valores de concentração de sólidos totais, e composição percentual de sólidos fixos totais e sólidos voláteis totais na água drenada.

\begin{tabular}{|c|c|c|c|c|c|c|}
\hline \multicolumn{7}{|l|}{ Ensaio 1} \\
\hline Tempo & \multicolumn{3}{|c|}{ Lodo de Sulfato de alumínio } & \multicolumn{3}{|c|}{ Lodo de PACl } \\
\hline$(\min )$ & ST (mg/L) & $\%$ SFT & $\%$ SVT & $\mathrm{ST}(\mathrm{mg} / \mathrm{L})$ & $\%$ SFT & $\%$ SVT \\
\hline 5 & 180 & 43 & 57 & 636 & 36 & 64 \\
\hline 60 & 145 & 10 & 90 & 171 & 17 & 83 \\
\hline 330(após chuva) & 333 & 80 & 20 & 233 & 64 & 36 \\
\hline \multicolumn{7}{|l|}{ Ensaio 2* } \\
\hline Tempo & \multicolumn{3}{|c|}{ Lodo de Sulfato de alumínio } & \multicolumn{3}{|c|}{ Lodo de PACl } \\
\hline$(\min )$ & ST (mg/L) & $\%$ SFT & $\%$ SVT & $\mathrm{ST}(\mathrm{mg} / \mathrm{L})$ & $\%$ SFT & $\%$ SVT \\
\hline 0,5 & - & - & - & 20 & - & - \\
\hline 2 & - & - & - & 600 & - & - \\
\hline 10 & - & - & - & 233,3 & - & - \\
\hline- & - & - & - & - & - & - \\
\hline
\end{tabular}




\begin{tabular}{|c|c|c|c|c|c|c|}
\hline \multirow{3}{*}{$\begin{array}{c}\text { Ensaio } 3 \\
\text { Tempo } \\
\text { (min) }\end{array}$} & \multirow{2}{*}{\multicolumn{3}{|c|}{ Lodo de Sulfato de alumínio }} & \multirow{2}{*}{\multicolumn{3}{|c|}{ Lodo de PACl }} \\
\hline & & & & & & \\
\hline & ST (mg/L) & $\%$ SFT & $\%$ SVT & ST (mg/L) & $\%$ SFT & $\%$ SVT \\
\hline 0,5 & - & - & & 960 & 0 & 100 \\
\hline 1 & 400 & 50 & 50 & 280 & 14 & 86 \\
\hline 5 & - & - & - & 200 & 20 & 80 \\
\hline 10 & - & - & - & 160 & 13 & 88 \\
\hline 15 & 280 & 43 & 57 & & & \\
\hline 30 & 280 & 29 & 71 & & & \\
\hline 60 & 400 & 60 & 40 & & & \\
\hline
\end{tabular}

* Ensaio 2 foi realizado apenas com amostra de lodo de PACl.

A Tabela 6.24 mostra que os valores de concentração de sólidos totais na água livre drenada proveniente de lodos de sulfato de alumínio variaram de 145 a $333 \mathrm{mg} / \mathrm{L}$ no Ensaio 1, e de 280 a $400 \mathrm{mg} / \mathrm{L}$ no Ensaio 3 . O valor de $333 \mathrm{mg} / \mathrm{L}$ foi obtido na água livre drenada após ocorrência de chuva.

Para a água livre drenada de lodo de $\mathrm{PACl}$, os valores de concentração de sólidos totais variaram de 636,4 a 171,4 mg/L no Ensaio 1, de 20 a $600 \mathrm{mg} / \mathrm{L}$ no Ensaio 2 e de 160 a $960 \mathrm{mg} / \mathrm{L}$ no Ensaio 3.

Em geral, os valores de concentração de sólidos nas amostras de água livre de lodo de $\mathrm{PACl}$ foram superiores aos obtidos para o lodo de sulfato de alumínio.

A percentagem de sólidos voláteis foi predominante nos dois tipos de lodos. Para o lodo de $\mathrm{PACl}$, os valores de SVT (\%) constituiu aproximadamente $80 \%$ dos sólidos totais, enquanto para o lodo de sulfato de alumínio SVT, cerca de $50 \%$.

No Ensaio 1 as amostras coletadas após a chuva apresentaram inversão na composição percentual dos sólidos. Os sólidos fixos predominaram na água drenada dos lodos de sulfato de alumínio e de PACl. Tal aspecto pode relacionar-se com ocorrência de cisalhamento de partículas anteriormente imobilizadas na massa de lodo e no leito filtrante (manta geotêxtil).

Os valores de concentração de sólidos totais encontrados nas amostras de água livre drenada dos lodos de sulfato de alumínio e de PACl, quando comparados aos teores de sólidos 
das amostras brutas dos lodos mostram a eficiência do Leito de Drenagem para remoção de sólidos.

A maior composição percentual de sólidos voláteis totais na água livre drenada indica a passagem de material de origem orgânica através do leito de drenagem. Para os lodos de PACl esse aspecto mostrou-se mais acentuado e pode estar relacionado com o uso de carvão ativado na ETA fornecedora da amostra e também com a matéria orgânica presente na água bruta removida pelo coagulante $\mathrm{PACl}$.

As considerações feitas relativas aos SV (\%), podem ser confirmadas pelas análises de COT na água livre drenada e pela composição das amostras de lodo bruto e retido determinados pela análise qualitativa via EDS e difração de raios-X.

\subsubsection{Valores de concentração de metais, DQO e COT}

Os valores de concentração de metais, demanda química de oxigênio e de carbono orgânico total foram determinados para as amostras de lodo de sulfato de alumínio e de PACl dos Ensaios 3 e 4. O Ensaio 3 caracteriza-se por representar um caso de situações extremas e o Ensaio 4 um caso típico.

Na Tabela 6.25 são apresentados os valores de concentração de metais encontrados, nas amostras brutas e amostras de água livre drenada do lodo de sulfato de alumínio e de PACl. 
Tabela 6.25 - Determinação da concentração de metais $(\mathrm{mg} / \mathrm{L})$ nas amostras de lodo bruto e de água livre drenada para os lodos de sulfato de alumínio e de $\mathrm{PACl}$, Ensaios 3 e 4. PACl

\begin{tabular}{|c|c|c|c|c|c|c|c|c|}
\hline \multirow{2}{*}{$\begin{array}{l}\text { Amostras } \\
\text { Ensaio } 3\end{array}$} & \multicolumn{8}{|c|}{ Metais (mg/L) } \\
\hline & \multirow[b]{2}{*}{ Zn } & \multirow[b]{2}{*}{$\mathbf{P b}$} & \multirow[b]{2}{*}{ Cd } & \multirow[b]{2}{*}{$\mathbf{N i}$} & \multirow[b]{2}{*}{$\mathbf{F e}$} & \multirow[b]{2}{*}{ Mn } & \multirow[b]{2}{*}{$\mathbf{C u}$} & \multirow[b]{2}{*}{$\mathrm{Cr}$} \\
\hline Lodo de PACl & & & & & & & & \\
\hline Lodo bruto & 3,92 & ND & ND & ND & 68,76 & ND & 0,95 & ND \\
\hline Drenado (5 min) & ND & ND & ND & ND & 10,63 & ND & ND & ND \\
\hline \multicolumn{9}{|l|}{ Ensaio 4} \\
\hline \multicolumn{9}{|c|}{$\begin{array}{l}\text { Lodo de Sulfato de } \\
\text { Alumínio }\end{array}$} \\
\hline Lodo bruto & 19,92 & ND & ND & ND & 57,26 & ND & 14,95 & ND \\
\hline Drenado (5 min) & 0,25 & ND & ND & ND & 3,48 & ND & ND & ND \\
\hline Drenado $(60 \mathrm{~min})$ & 0,33 & ND & ND & ND & 1,84 & ND & ND & ND \\
\hline \multicolumn{9}{|l|}{ Lodo de PACl } \\
\hline Lodo bruto & 3,92 & ND & ND & ND & 98,76 & ND & 1,95 & ND \\
\hline Drenado (5 min) & 0,06 & ND & ND & ND & 0,11 & ND & ND & ND \\
\hline Drenado (60 $\mathrm{min})$ & 1,22 & ND & ND & ND & 0,41 & ND & ND & ND \\
\hline
\end{tabular}

Muito embora, o elemento alumínio não tenha sido medido nessa pesquisa, diversos autores brasileiros, tais como Fontana (2004), Cordeiro (2001) mostram que o desaguamento por leito de drenagem é efetivo na retenção de alumínio.

Apesar de reportado na literatura brasileira, não foi constatada a presença de chumbo e níquel nas amostras de lodo bruto e tão pouco na água drenada. O leito de drenagem mostrouse efetivo na retenção de zinco, ferro e cobre.

$\mathrm{Na}$ água livre drenada de lodo de $\mathrm{PAC} \ell$ do Ensaio 4, a concentração de zinco elevou de $0,06 \mathrm{mg} / \mathrm{L}$ no tempo de 5 minutos para $1,22 \mathrm{mg} / \mathrm{L}$ no tempo de 60 minutos, o que também foi observado para o ferro (de 0,11 para $0,41 \mathrm{mg} / \mathrm{L}$ ). Deve ser ressaltado que no tempo $\mathrm{t}=60$ minutos, cerca de $95 \%$ do volume de água livre havia sido drenada.

No Ensaio 3, os baixos valores de concentração de metais devem ser vistos com ressalvas, uma vez que aos 5 minutos de ensaio, 85 \% da água livre já havia sido drenada com turbidez próximas de $350 \mathrm{uT}$.

Para os dois tipos de lodos estudados, de sulfato de alumínio e de PACl, o Leito de Drenagem mostrou-se efetivo na remoção dos metais. As concentrações dos metais, ferro, 
zinco e cobre estão abaixo dos padrões de lançamentos preconizados pela Resolução $\mathrm{N}^{0}$ 375/2005 (CONAMA, 2005) e são preponderantes na determinação do destino ou aproveitamento adequado da fração líquida do lodo desaguado.

Para determinação de carbono orgânico total nas amostras lodo bruto e desaguado e da água drenada foram estudados diversos métodos analíticos, contudo sem obter pleno êxito, conforme reportado no Capítulo 5, seção 5.7.6.

Apesar disso, apresentam-se resultados que podem indicar comportamento e tendência do fluxo de material orgânico (carbono orgânico total) no decorrer dos ensaios de desaguamento por Leito de Drenagem.

Na Tabela 6.26 são apresentados os valores de demanda química de oxigênio (DQO) e carbono orgânico total (COT) encontrados nas amostras de lodo bruto e água drenada de lodos de sulfato de alumínio e de $\mathrm{PAC} \ell$ para os Ensaios 3 e 4.

Tabela 6.26 - Concentração de DQO e COT em mg/L nas amostras de lodo bruto e de água livre drenado para os Ensaios 3 e 4 realizados com lodo de sulfato de alumínio e de PACl.

\begin{tabular}{l|c|c|c|c}
\hline Amostras & \multicolumn{2}{|c|}{ Lodo de Sulfato de Alumínio } & \multicolumn{2}{c}{ Lodo de PACl } \\
\hline Ensaio 3 & \multicolumn{2}{|c|}{ ST (\%) $=\mathbf{7 , 6}$} & \multicolumn{2}{c}{ ST (\%) =0,04 } \\
\hline & DQO (mg/L) & COT $(\mathrm{mg} / \mathrm{L})$ & DQO $(\mathrm{mg} / \mathrm{L})$ & COT (mg/L) \\
\hline Lodo Bruto & 7000 & 553 & 336 & 107 \\
\hline Drenado (5 min) & - & 227 & - & 76 \\
\hline Ensaio 4 & \multicolumn{2}{|c|}{ ST (\%) $=\mathbf{0 , 7 6 \%}$} & \multicolumn{2}{c}{ ST (\%) $\mathbf{0 , 2 6}$} \\
\hline Lodo Bruto & 1295 & 134 & 308 & 36 \\
\hline Drenado (5 min) & - & 398 & - & 217 \\
\hline
\end{tabular}

- amostra perdida

Os valores de DQO para o lodo de sulfato de alumínio são elevados e concordam com o encontrado na literatura. Apesar do coagulante $\mathrm{PAC \ell}$ ser usado para melhorar a remoção de matéria orgânica da água bruta durante o tratamento de água, os lodos gerados não apresentaram valores de DQO tão elevados quanto os lodos de sulfato de alumínio. Por outro lado, há de considerar os baixos teores de sólidos das amostras de lodos de PACl. 
A variação dos valores de concentração COT acompanhou a variação de DQO. Os valores de concentração de COT foram mais elevados para as amostras brutas de lodo de sulfato de alumínio que as de lodo de $\mathrm{PACl}$. Salienta-se que a concentração de sólidos de sulfato de alumínio é mais elevada que a do lodo de PACl.

No Ensaio 3, houve redução de COT na água drenada, ao contrário do Ensaio 4 em que houve aumento dos valores de COT na água drenada, para os lodos de sulfato de alumínio e de PACl. Tal ocorrência pode indicar existência de cisalhamento e desprendimento de partículas retidas na manta geotêxtil ou até mesmo evidenciou possíveis interferentes nas análises de COT das amostras de lodo e de água drenada, conforme reportados no Capítulo 5, seção 5.7.6, relativo aos estudos de determinação de COT.

\subsubsection{Avaliação do desaguamento por leito de drenagem - Fase de Secagem}

Na seção 6.3.4 são discutidos os resultados relativos à Fase de Secagem, no que tange à evolução da secagem e influência das variáveis climáticas.

Para as amostras de lodo bruto e lodos desaguados retidos nas mantas geotexteis são apresentados os resultados de distribuição de tamanho de partículas, morfologia e composição química por microscopia eletrônica de varredura acoplada a Espectroscopia por Dispersão de Energia de Raios-X (MEV/EDS) e estrutura cristalina por análises de difração de raio-X. Também são apresentadas micrografias obtidas por MEV das mantas geotêxteis usadas nos ensaios de desaguamento por Leito de Drenagem.

A Tabela 6.27 apresenta o resumo geral dos resultados de teor de sólidos em (\%), relativo à fase de secagem de cada ensaio de desaguamento. As células hachuradas correspondem aos teores de sólidos dos lodos ao fim da drenagem e início da fase de secagem. 
Tabela 6.27 - Variação de teor de sólidos durante a Fase de Secagem.

\begin{tabular}{|c|c|c|c|c|c|c|c|c|c|c|c|}
\hline Ensaios & \multirow{2}{*}{\multicolumn{2}{|c|}{$\frac{1}{\mathrm{I}}$}} & 2 & \multirow{2}{*}{\multicolumn{2}{|c|}{$\begin{array}{l}3 \\
\text { II }\end{array}$}} & \multicolumn{2}{|c|}{4} & \multirow{2}{*}{\multicolumn{2}{|c|}{$\frac{5 \mathbf{A}}{\mathrm{II}}$}} & \multirow{2}{*}{\multicolumn{2}{|c|}{$\begin{array}{c}\text { 5B } \\
\text { II }\end{array}$}} \\
\hline Protótipo & & & I & & & \multirow{2}{*}{$\frac{\mathrm{I}}{\mathrm{Al}_{2} \mathrm{SO}_{4}}$} & \multirow{2}{*}{$\frac{\mathrm{I}}{\mathrm{PACl}}$} & & & & \\
\hline Coagulante & $\mathrm{Al}_{2} \mathrm{SO}_{4}$ & $\mathrm{PACl}$ & $\mathrm{PACl}$ & $\mathrm{Al}_{2} \mathrm{SO}_{4}$ & $\mathrm{PACl}$ & & & $\mathrm{Al}_{2} \mathrm{SO}_{4}$ & $\mathrm{PACl}$ & $\mathrm{Al}_{2} \mathrm{SO}_{4}$ & $\mathrm{PACl}$ \\
\hline Volume (L) & 25 & 25 & 20 & 8 & 8 & 55 & 55 & 8 & 8 & 8 & 8 \\
\hline TAS $\left(\mathrm{kg} / \mathrm{m}^{2}\right)$ & 3,43 & 1,86 & 0,23 & 7,35 & 0,04 & 2,20 & 0,76 & 2,61 & 0,27 & 4,06 & 0,20 \\
\hline $\begin{array}{c}\text { Tempo } \\
\text { (dias) }\end{array}$ & \multicolumn{2}{|c|}{ ST (\%) } & ST (\%) & \multicolumn{2}{|c|}{ ST (\%) } & \multicolumn{2}{|c|}{ ST (\%) } & \multicolumn{2}{|c|}{ ST (\%) } & \multicolumn{2}{|c|}{ ST (\%) } \\
\hline 1 & 13,4 & 8,8 & 13,0 & 17,3 & 13,0 & 23,4 & 16,7 & 18,3 & $*$ & 14,5 & $*$ \\
\hline 2 & 15,5 & 11,1 & 13,5 & 24,6 & 53,3 & 55,2 & 46,6 & 25,2 & & 20,5 & \\
\hline 3 & 16,8 & 11,9 & 25,2 & 28,3 & $*$ & 72,3 & $*$ & 39,8 & & 25,3 & \\
\hline 4 & 23,3 & 22,7 & 85,9 & 35,7 & & 96,7 & & 35,4 & & 38,5 & \\
\hline 5 & 22,3 & 19,0 & 89,4 & 37,5 & & 93,3 & & 38,2 & & 33,3 & \\
\hline
\end{tabular}

$\sqcup-$ Amostra de lodo com teor de sólidos, ST > $30 \%$.

$\square-$ Amostra de lodo com teor de sólidos inicial, $\left(\mathrm{ST}_{\mathrm{os}}\right)$ da Fase de Secagem

* O resíduo retido esturricou e impossibilitou coleta de amostras. PACl

** Td = teor de sólidos ao fim da Fase de Drenagem (tempo de drenagem-Td) e corresponde ao teor de sólidos inicial, $\mathrm{ST}_{\text {os }}$ da Fase de Secagem. 
A Figura 6.42 apresenta a variação diária do teor de sólidos, ST (\%) dos lodos de sulfato de alumínio e de $\mathrm{PAC} \ell$ para cada ensaio de desaguamento realizado. Nos Ensaios 2, 3 e 4 ocorreu acentuada elevação do teor de sólidos, quando ST (\%) ultrapassou valores próximos de $30 \%$.
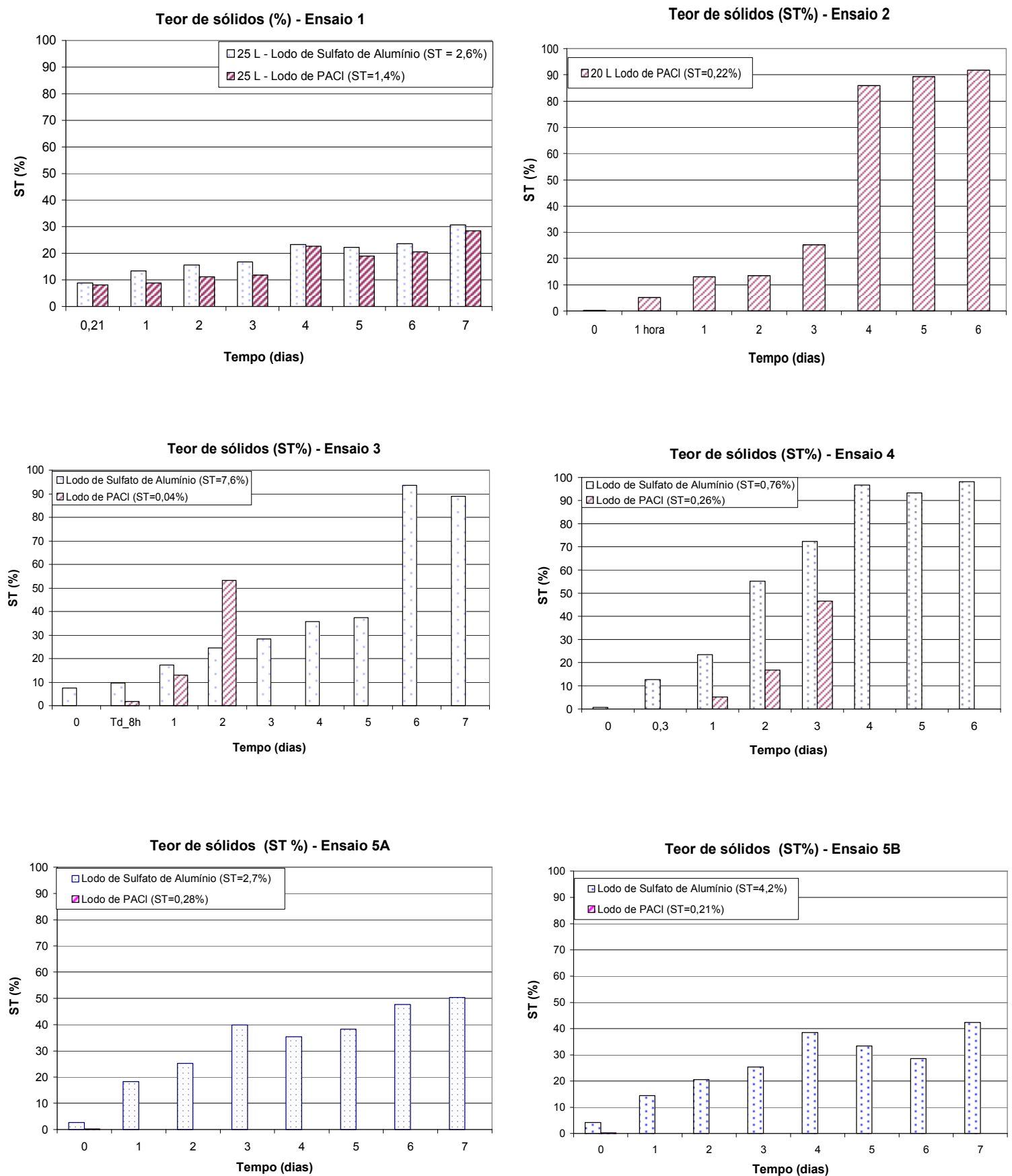

Figura 6.42 - Variação do teor de sólidos para lodos de sulfato de alumínio e de PACl 
Para compreender melhor a evolução da secagem, optou-se por representar a variação de teor de sólidos na forma de curvas de secagem e cálculos de fluxo de massa de água evaporada por unidade de área e unidade de tempo (Figura 6.43).

As curvas de secagem assim como os gráficos de fluxo de massa de água evaporada foram construídas a partir das seguintes proposições:

I - Ao término da fase de drenagem da água livre, a massa de lodo retida com um determinado teor de sólidos (STd), é exposta a ação das variáveis climáticas sob uma temperatura (T), pressão de vapor da água no $\operatorname{ar}(\mathrm{Par})$ e umidade relativa do $\operatorname{ar}(\mathrm{Wr})$.

II - O teor de sólidos na massa de lodo tende a evoluir até atingir equilíbrio térmico com o meio, apresentando um valor de teor de sólidos (STi) maior ou menor que STd.

III - A diferença entre STi e STd fornece indiretamente a diferença entre a umidade na base seca inicial $\left(\mathrm{Wd}_{\mathrm{o}}\right)$ e final (Wdi) num determinado intervalo de tempo, mediante uso da Equação 6.2. A relação entre $\mathrm{Wd}_{\mathrm{o}}$ e $\mathrm{Wd}_{\mathrm{i}}$ denota a intensidade da perda por evaporação ou absorção da água na massa de lodo.

$\mathrm{Wd}=(1 / \mathrm{ST})-1$

Onde:

$$
\begin{aligned}
& \mathrm{Wd}=\text { umidade na base seca }(\%) ; \\
& \mathrm{ST}=\text { teor de sólidos na base úmida }(\%) .
\end{aligned}
$$

IV - A intensidade da perda da água por evaporação pode então ser definida como a velocidade de secagem ou fluxo de massa de água ou umidade que é retirada do lodo por unidade de área de exposição e por unidade de tempo, ou seja, expresso por $\mathrm{kg}$ água $/ \mathrm{m}^{2} . \mathrm{T}$ (unidade de tempo) e representada pela Equação 6.3.

$$
\mathrm{F}_{\mathrm{mar}}=\mathrm{Md} / \mathrm{A} \times\left(\mathrm{dW}_{\mathrm{d}} / \mathrm{dt}\right)
$$

Em que:

$$
\mathrm{Md}=\text { massa de sólidos na base seca }(\mathrm{kg})
$$




$$
\begin{aligned}
& A=\text { área de exposição ou de transferência de vapor de água }\left(\mathrm{m}^{2}\right) \\
& \mathrm{dW}_{\mathrm{d}}=\text { variação de umidade do lodo em base seca; } \\
& \mathrm{dt}=\text { variação do tempo (dia). }
\end{aligned}
$$

Assim, o cálculo do fluxo de massa de água retirado por evaporação $\mathrm{F}_{\operatorname{mar}}$ nos ensaios realizados foi feito tornando $\mathrm{Md} / \mathrm{A}$ igual à TAS (taxa de aplicação de sólidos), expresso em $\mathrm{kg} / \mathrm{m}^{2}$. A variação $\Delta \mathrm{W}_{\mathrm{d}}$ obtido de $\Delta \mathrm{ST}$, a partir da Equação 6.2 , em que $\mathrm{ST}_{\mathrm{o}}$ corresponde ao teor de sólidos inicial, Td da Fase de Secagem (Tabela 6.27).

O cálculo de $\mathrm{F}_{\mathrm{mar}}$ foi feito considerando a variação diária.

Entretanto, o cálculo de $\mathrm{F}_{\mathrm{mar}}$ para o primeiro dia de cada ensaio realizado foi obtido considerando $d t=t_{1 \text { dia }}-t_{o}$, sendo $t_{o}=T_{d}$, para quando tempo de drenagem, (Td) maior que 1 hora. Assim, o cálculo do fluxo de massa no primeiro dia foi baseado na diferença entre 24 horas e a duração em horas da fase de drenagem. Nos Ensaios 5A e 5B não foram determinados os teores de sólidos correspondentes ao início da fase de secagem (fim da fase de drenagem), o que impossibilitou o cálculo do fluxo de massa de água evaporada para o primeiro dia.

Os cálculos do fluxo de massa de umidade ou de água evaporada são apresentados na Tabela A7, Anexo A. Na Figura 6.43 são apresentados os gráficos de curva de secagem e de fluxo de massa de água evaporada (sorção e dessorção) por unidade de área e unidade de tempo, da massa de lodo retida no leito de drenagem.

Nos gráficos de fluxo de massa de umidade (água evaporada), os valores negativos correspondem à perda de água da massa de lodo por evaporação (dessorção) e os valores positivos a ocorrência de absorção da umidade do ar pela massa de lodo (sorção). 

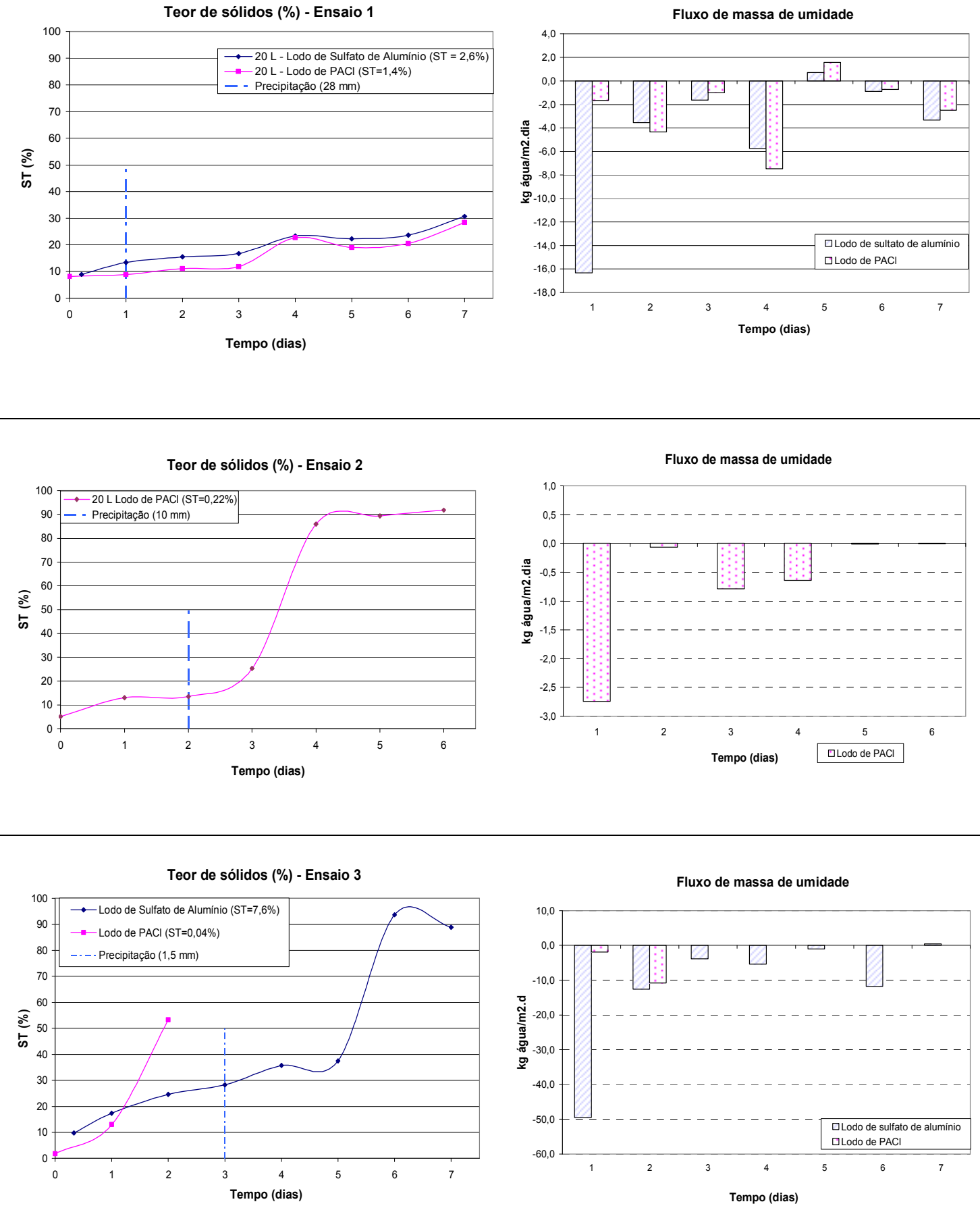

Figura 6.43 - Gráficos de curva de secagem e de fluxo de massa de umidade ( $\mathrm{kg}$ água $/ \mathrm{m}^{2}$.dia) para os Ensaios 1, 2, 3, 4, 5A e 5B. 

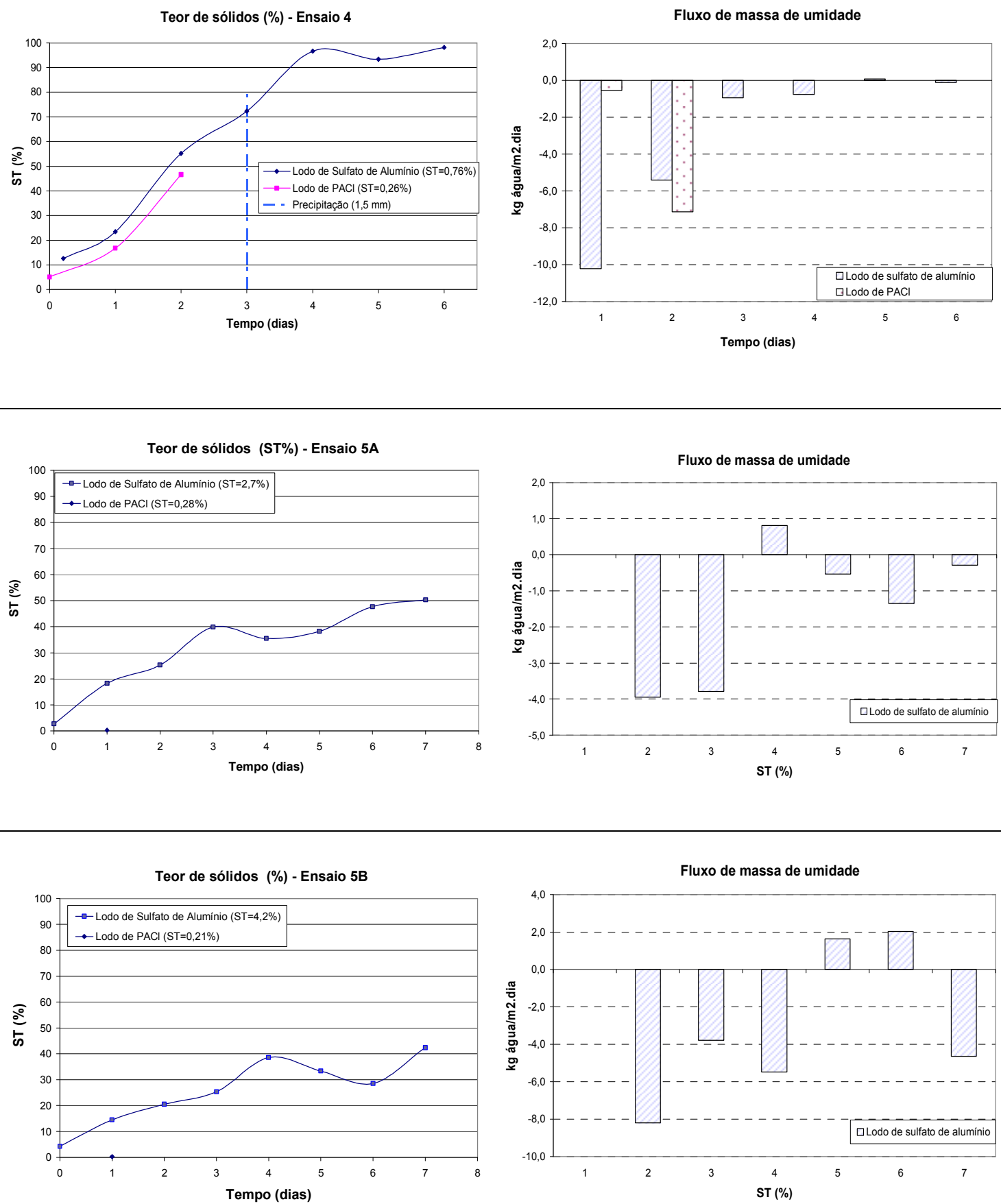

Figura 6.43 - Gráficos de curva de secagem e de fluxo de massa de umidade (kg água $/ \mathrm{m}^{2}$.dia) para os Ensaios 1, 2, 3, 4, 5A e 5B.

Quando da realização do Ensaio 1 ocorreu precipitação $(28 \mathrm{~mm})$ no primeiro dia de secagem. O fluxo de massa de umidade (perda de água por evaporação) para o lodo de sulfato 
de alumínio foi em torno de - $16 \mathrm{~kg}$ água $/ \mathrm{m}^{2}$.dia, enquanto para lodo de PACl somente $-1,7$ $\mathrm{kg}$ água $/ \mathrm{m}^{2}$, os valores de ST (\%) atingiram cerca de $13 \%$ (lodo de sulfato de alumínio) e 8,8 $\%$ (lodo de PACl). No intervalo entre $\mathrm{t}=2 \mathrm{a} \mathrm{t}=4$ dias, os dois tipos de lodo apresentaram comportamentos similares da variação de fluxo de massa de umidade. Porém, para os lodos de PACl, os fluxos de umidade (perda de água por evaporação) foram mais elevados que no primeiro dia.

Para o Ensaio 2 (lodo de $\mathrm{PACl}$ ), o fluxo de massa de umidade (perda de água por evaporação) no primeiro dia foi de $-2,74 \mathrm{~kg}$ água $/ \mathrm{m}^{2}$.dia. A maior parcela do fluxo de massa de água evaporada ocorreu no primeiro dia de secagem e o teor de sólidos foi de aproximadamente, $13,5 \%$. No segundo dia ocorreu chuva (precipitação $=10 \mathrm{~mm}$ ) e como resultado, o fluxo de umidade foi praticamente nulo.

No terceiro dia, o fluxo de massa de umidade foi de $-0,79 \mathrm{~kg}$ água $/ \mathrm{m}^{2}$.dia e $\mathrm{ST}=25$ \%. No intervalo de tempo entre $\mathrm{t}=3$ a $\mathrm{t}=4$ dias houve elevação brusca do teor de sólidos para aproximadamente $\mathrm{ST}=86 \%$ e o fluxo de umidade igual a $-0,8 \mathrm{~kg}$ água $/ \mathrm{m}^{2}$. Nos intervalos de 5 a 6 dias, o fluxo de umidade foi pequeno, em torno de - $0,1 \mathrm{~kg}$ água $/ \mathrm{m}^{2}$, quando então não foi mais possível coletar resíduos do lodo de sulfato de alumínio.

Nos ensaios 3 e 4, como já ocorrera no Ensaio 1, o fluxo de umidade (perda de água por evaporação) para o lodo de sulfato de alumínio foi elevado no primeiro dia de secagem, enquanto para o lodo de $\mathrm{PACl}$, a maior parcela de fluxo de água evaporada ocorreu a partir do segundo dia de secagem.

Foram confirmadas ocorrência de elevações bruscas de ST (\%), destacadamente para o lodo de sulfato de alumínio do Ensaio 3, para quando os lodos desaguados apresentaram teores de sólidos acima de $30 \%$. 
Para os lodos de sulfato de alumínio, obteve-se ST (\%) acima de 90 \% e ocorrência de sorção (fluxo de massa de umidade positivo). Os lodos de PACl esturricaram após atingirem valores de ST (\%) acima de $40 \%$.

Para os Ensaios 5A e 5B, a maior parcela de fluxo de massa de umidade dos lodos de sulfato de alumínio ocorreu nos primeiros três dias. No segundo dia, o fluxo de massa de umidade foi de $-4 \mathrm{~kg}$ água $/ \mathrm{m}^{2}$ para o Ensaio 5A, enquanto para Ensaio $5 \mathrm{~B}$ foi duas vezes maior, cerca de $-8 \mathrm{~kg}$ água $/ \mathrm{m}^{2}$. Nos dois Ensaios (5A e 5B), ocorreu sorção diante da elevação da umidade relativa do ar (alteração na relação pressão de vapor da água no ar e no lodo) e ocorrência de chuva.

As amostras de lodo de sulfato de alumínio desaguados dos Ensaios 5A e 5B apresentavam mesmo volume de aplicação e foram submetidas às mesmas variáveis climáticas. Porém, o teor de sólidos do lodo do ensaio $5 \mathrm{~B}, \mathrm{ST}_{\mathrm{o}}=4,20 \%$ foi cerca de duas vezes maior, que o teor de sólidos do lodo do ensaio $5 \mathrm{~A}, \mathrm{ST}_{\mathrm{o}}=2,61 \%$. Ao fim da drenagem de água livre e início da fase de secagem (primeiro dia), o lodo do ensaio 5B apresentou teor de sólidos, $\mathrm{ST}=14,5 \%$ e o lodo do ensaio $5 \mathrm{~A}, \mathrm{ST}=18 \%$, ou seja, a remoção de água livre drenada foi mais efetiva para o lodo com menor teor de sólidos (Ensaio 5A).

Assim, pode-se inferir que após a fase de drenagem, o lodo desaguado de sulfato de alumínio do Ensaio 5B possuiu maior parcela de água de ligação e/ ou não drenada que 5A, e que por sua vez foi retirada por evaporação.

Esta observação torna-se interessante, pois pode indicar que, se por um lado um lodo possui elevada parcela de água de ligação que porventura tem maior dificuldade de ser drenada, por outro lado na Fase de Secagem é vantajoso, pois favorece a formação de um filme líquido continuo na superfície da massa de lodo.

Segundo David (2005), a formação desse filme líquido contínuo promove a evaporação da água como se não existisse interação com sólidos. Assim, a velocidade de 
secagem ou fluxo de massa de umidade apresenta-se mais elevada que naqueles lodos que não possuem a formação do filme liquido contínuo, como no caso dos lodos drenados com maior eficiência (maior teor de sólidos ao fim da fase de drenagem).

Algumas considerações gerais sobre os resultados apresentados são aqui relatados.

Nos ensaios de desaguamento que atingiram valores de teor de sólidos acima de $30 \%$ houve elevação brusca do teor de sólidos até valores próximos de $90 \%$ ou esturricaram as amostras de lodo desaguado. Isto aconteceu independente do volume de amostra de lodo, como é o caso dos Ensaios 2, 3 e 4. Já para os Ensaios 1, 5A e 5B, as condições climáticas atenuaram esta tendência e obtiveram-se valores finais de ST em torno de $30 \%$.

As amostras de lodo de $\mathrm{PACl}$ esturricaram nos ensaios 3, 4, 5A e 5B, provavelmente devido à pequena massa de lodo mais água retida após a fase de drenagem.

A ocorrência da elevação brusca ou "salto" na evolução da secagem também foi encontrada por Fontana (2004), em seu estudo sobre a implantação em escala real do leito de drenagem para desaguamento de lodo de sulfato de alumínio proveniente de ETA convencional de ciclo completo. A abordagem da fase de secagem considerando o fluxo de massa de água evaporada permitiu elucidar melhor essa questão.

De maneira geral, o fluxo de massa de água evaporada apresentou valores decrescentes com o tempo. Entretanto, os lodos de sulfato de alumínio apresentaram fluxo de água evaporada mais elevado, logo após o encerramento da fase de drenagem (primeiro dia de secagem), que nos demais dias. Já para os lodos de $\mathrm{PACl}$, o fluxo de retirada de água foram mínimos no primeiros dias e maior nos demais.

O comportamento distinto entre os lodos de sulfato de alumínio e de PACl, em relação o fluxo de água evaporada nos primeiros dias da fase de secagem, pode estar relacionado com as condições internas da fração sólida (quantidade, características, forma e natureza da massa do lodo desaguado). 
David (2002) reporta que o processo de secagem em materiais higroscópicos porosos, como no caso de lodo de ETAs, é complexo, mas pode ser subdividido em:

a) fluxo de umidade retirado pela porção interna mediante transporte de água e vapor de água, através dos sólidos por capilaridade e difusão até a superfície;

b) remoção de água da superfície na forma de vapor, em função da relação pressão de vapor da água no lodo e pressão de vapor da água no ar.

Assim, a umidade na massa de lodo pode ter uma componente de umidade livre, em que o fluxo ocorre como se não houvesse sólidos, ou seja, sem a interferência ou etapa de fluxo interno e uma componente de umidade de ligação, em que a água está ligada aos sólidos e que portanto, a fase interna exerce influência considerável. Salienta-se que David (2002) aborda esses mecanismos relativos ao estudo com lodos de ETEs, e que os mesmos podem fornecer indicações quanto aos lodos de ETAs, mas com ressalvas, visto as distintas características entre esses dois tipos de lodos.

Dessa forma, pode-se deduzir que os lodos de sulfato de alumínio após a fase de drenagem apresentavam ainda considerável parcela de água livre que, de alguma maneira não foi drenada, sendo removida por evaporação nos primeiros dias.

Já o lodo de PACl, apresentou na maioria dos Ensaios, menor teor de sólidos que os lodos de sulfato de alumínio. Porém, a parcela de água livre foi menor, e conseqüentemente ocasionou mínima evaporação nos primeiros dias de secagem até ser estabelecido o fluxo interno de retirada de água.

Contudo, as assertivas destas observações supracitadas na evolução da secagem dos lodos de ETAs poderam ser realizada, mediante o desenvolvimento de pesquisas específicas 
que contemplem o estudo do fluxo de umidade das massas de lodos desaguados por Leito de Drenagem. A necessidade destas pesquisas também deve ser analisada criteriosamente.

\subsubsection{Influência das variáveis climáticas na Fase de Secagem}

As Figuras 6.44 a 6.49 apresentam os resultados das variáveis climáticas; precipitação, umidade relativa do ar, insolação, evaporação, vento e temperatura para avaliação conjunta dos ensaios realizados, Ensaios 1, 2, 3, 4, 5A, e 5B.

Observa-se, a partir da Figura 6.44 que a precipitação não exerceu influência significativa na evolução da secagem. Quando da ocorrência de precipitação, a água da chuva não permaneceu incorporada à massa de lodo. Apesar disso, nos Ensaios 1, Ensaio 5A e 5B, a precipitação promoveu a elevação da umidade relativa do ar e conseqüentemente a diminuição do fluxo de umidade (estabilização do teor de sólidos na faixa de 30 a 50 \%), afetando a evolução da secagem. Praticamente toda água precipitada foi drenada. Nos Ensaios 3 e 4, os valores de precipitação (cerca de 1,5 mm) não influenciaram no desempenho da secagem.

Fontana (2004) relata que a ocorrência de precipitação no primeiro dia de secagem, antes da "abertura" da massa de lodo é potencialmente mais prejudicial à secagem do lodo. No Ensaio 1, constatou-se tal observação. Porém, mostrou ser de influência pontual e que a elevada umidade relativa do ar promovida pela chuva é que pode ter influenciado a secagem do lodo desaguado. 

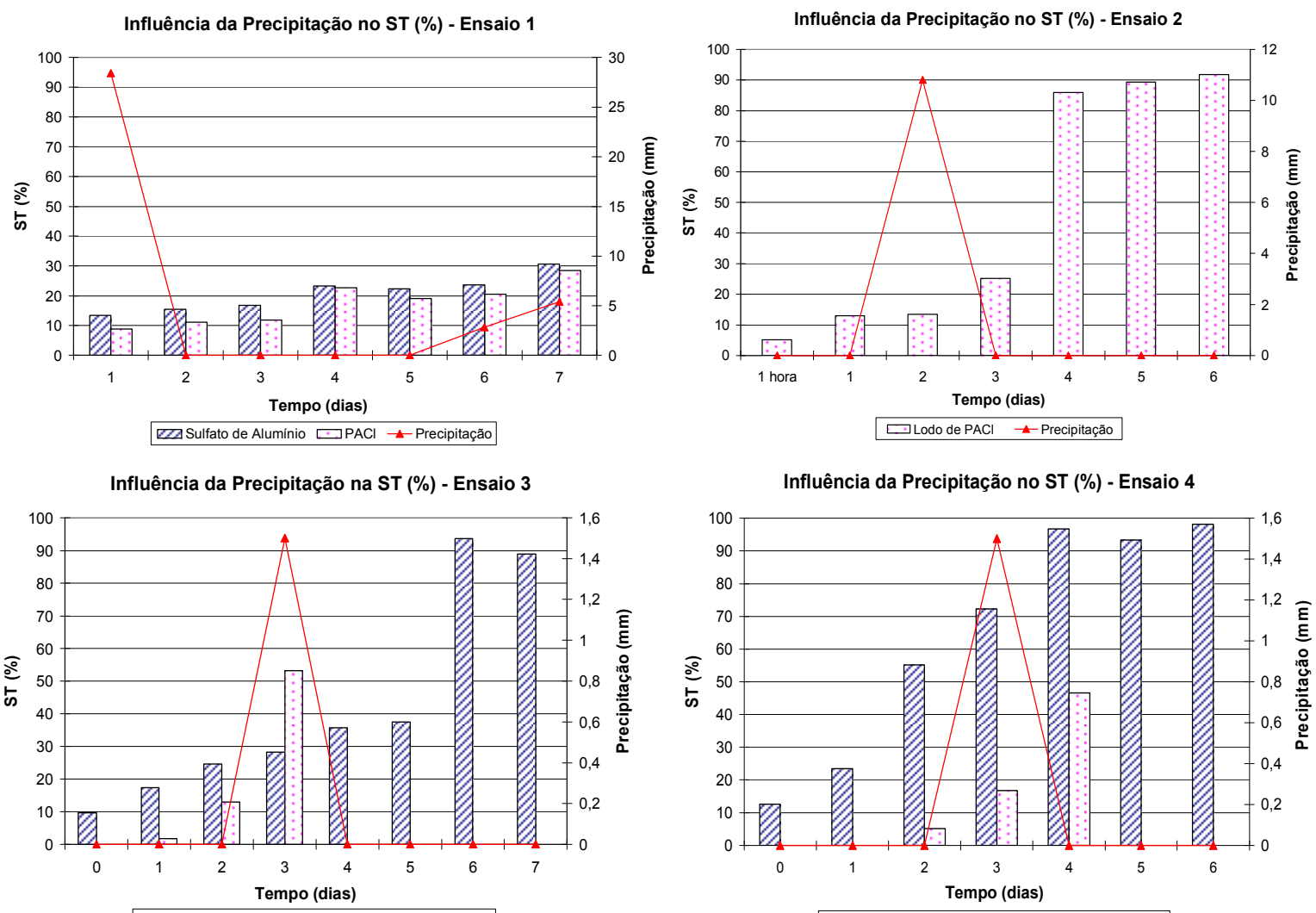

एSulfato de Aluminio $\square \mathrm{PACl}$ ‡-Precipitação
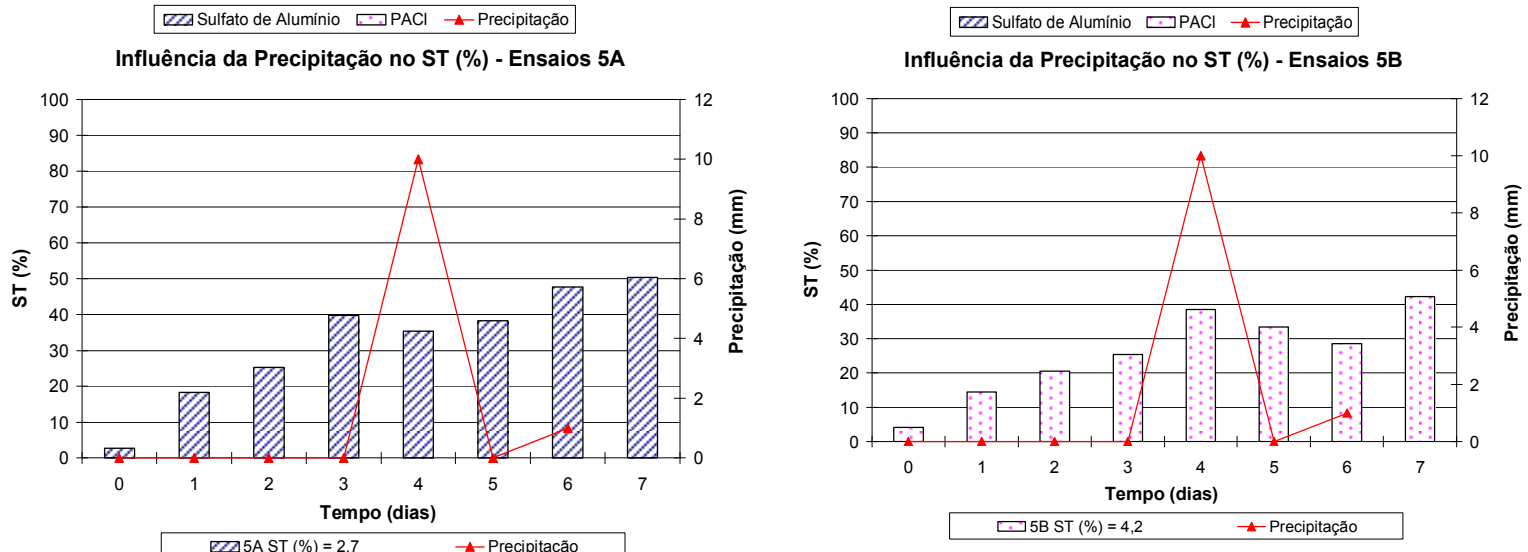

Figura 6.44 - Variação da precipitação em $(\mathrm{mm})$ e do teor de sólidos totais (\%ST) para cada ensaio de desaguamento por Leito de Drenagem (Fase de Secagem).

Na Figura 6.45 são apresentados os resultados de umidade relativa do ar.

Nos Ensaios 3 e 4, ocorreu a elevação acentuada do teor de sólidos dos lodos de sulfato de alumínio e de $\mathrm{PACl}$, à medida que a umidade relativa do ar diminui. No Ensaio 2, quando a umidade relativa do ar apresentou valores próximos ou acima de $70 \%$, a secagem foi prejudicada. Nos Ensaios 1, 5A e 5B, a umidade relativa do ar permaneceu sempre acima 
de $70 \%$ e a secagem estabilizou com valores de teor de sólidos próximos de $30 \%$, e em alguns casos até $50 \%$.

Portanto, apesar das diferentes condições de ensaios quanto aos tipos, características e volume de aplicação das amostras de lodos no Leito de Drenagem, a umidade mostrou-se determinante na evolução e velocidade de secagem, pois é fundamental no equilíbrio da relação de pressão de vapor da água do sistema lodo-ar.
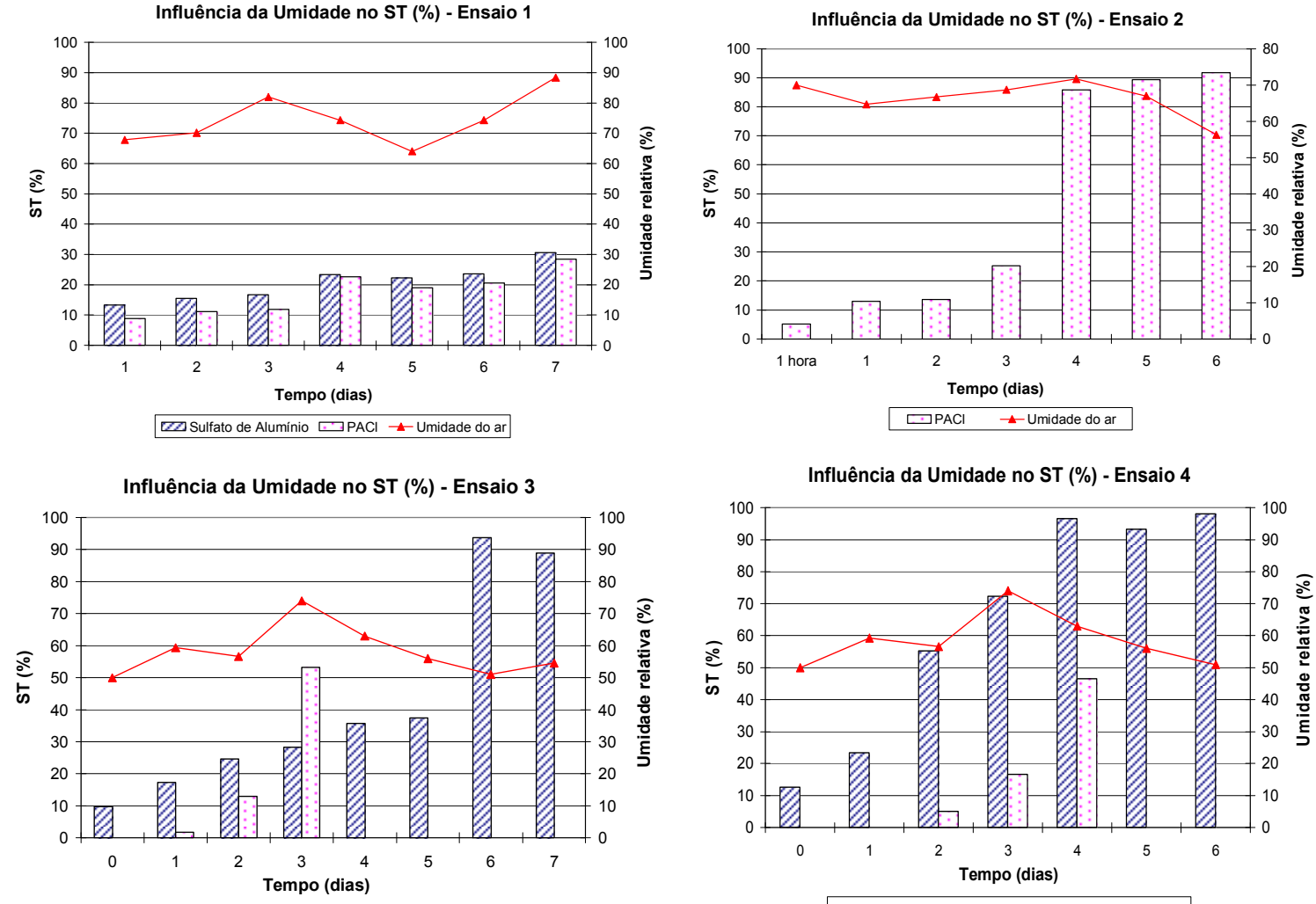

$\square \triangle$ Sulfato de Aluminio $\square \mathrm{PACl} \rightarrow$ Umidade do ar
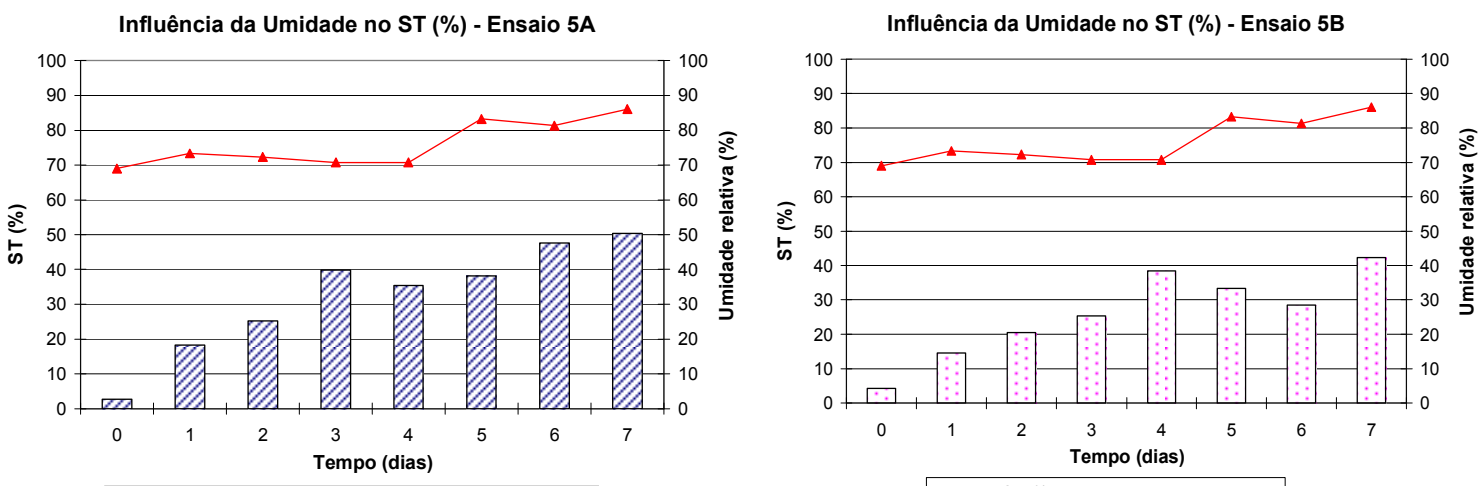

$-5 \mathrm{~B} \mathrm{ST}(\%)=4,2 \quad \neg$ Umidade do ar

Figura 6.45 - Variação da umidade relativa do ar em (\%) e do teor de sólidos totais (\%ST) para cada ensaio de desaguamento por Leito de Drenagem (Fase de Secagem). 
A insolação pode ser compreendida como, a variável que fornece a energia térmica necessária para evaporação da água contida na massa de lodo (fluxo de massa de água evaporada). Os resultados de insolação são fornecidos em horas e constam na Figura 6.46.

Nos Ensaios 1, 5A e 5B, ocorreu a diminuição brusca do valor de insolação, a partir do quarto dia e foi acompanhada da estabilização dos valores de teor de sólidos ST para os dois tipos de lodos estudados. Ressalta-se que a umidade relativa do ar apresentou valores acima de $70 \%$. Por outro lado, a elevação acentuada da insolação nos Ensaios 2, 3 e 4 foi acompanhada do aumento do teor de sólidos.

Dessa forma, os resultados relativos aos valores de insolação mostraram-se decisivos para a velocidade de secagem, e conseqüentemente no desempenho do leito de drenagem. Pode-se inferir que a variável insolação teve relação diretamente proporcional com a variação de teor de sólidos nas amostras de lodos desaguados no leito de drenagem. 

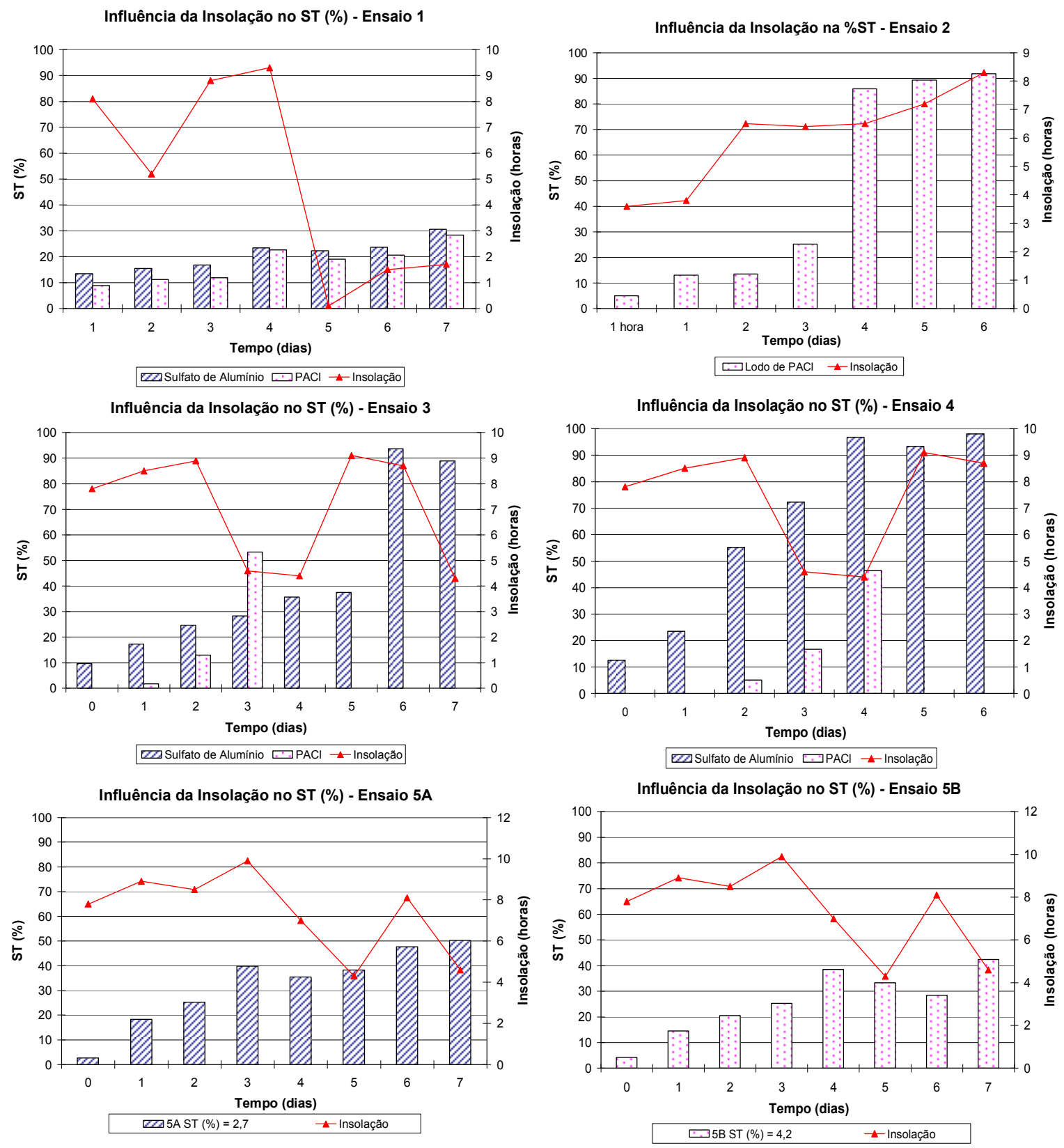

Figura 6.46 - Variação da insolação (horas) e do teor de sólidos totais (\%ST) para cada ensaio de desaguamento por Leito de Drenagem (Fase de Secagem).

A evaporação pode ser uma forma indireta de indicar ou representar o fluxo de umidade perdida do lodo, ao invés de uma variável determinante na secagem de lodos.

Os resultados da variação de evaporação para cada ensaio de desaguamento são apresentados na Figura 6.47. 
No Ensaio 1, os valores de evaporação foram baixos e variaram aproximadamente de 1 a $3 \mathrm{~mm}$. No Ensaio 2, a evaporação no primeiro dia de ensaio foi de $1 \mathrm{~mm}$, depois os valores variaram de 3 a $8 \mathrm{~mm}$ e coincidiu com elevado aumento no teor de sólidos nas amostra de lodo de PACl.

Nos Ensaios 3 e 4, os valores de evaporação situaram-se acima de $3 \mathrm{~mm}$, variando até $8 \mathrm{~mm}$. Porém, para o Ensaio 3, a velocidade de secagem (variação de teor de sólidos) apresentou relação diretamente proporcional à variação dos resultados de evaporação, enquanto para o Ensaio 4 esta relação mostrou-se evidente somente para os dois dias iniciais do ensaio de desaguamento. A causa dos comportamentos distintos pode estar relacionada com os valores de teor de sólidos inicial na fase de secagem e conseqüentemente aos distintos mecanismos de secagem da massa de lodo.

Nos Ensaios 5A e 5B os valores de evaporação foram elevados nos primeiros dias, cerca de $5 \mathrm{~mm}$. Após o segundo dia, os valores de evaporação decresceram e coincidiram com a diminuição da secagem das amostras de lodos (estabilização da secagem). 

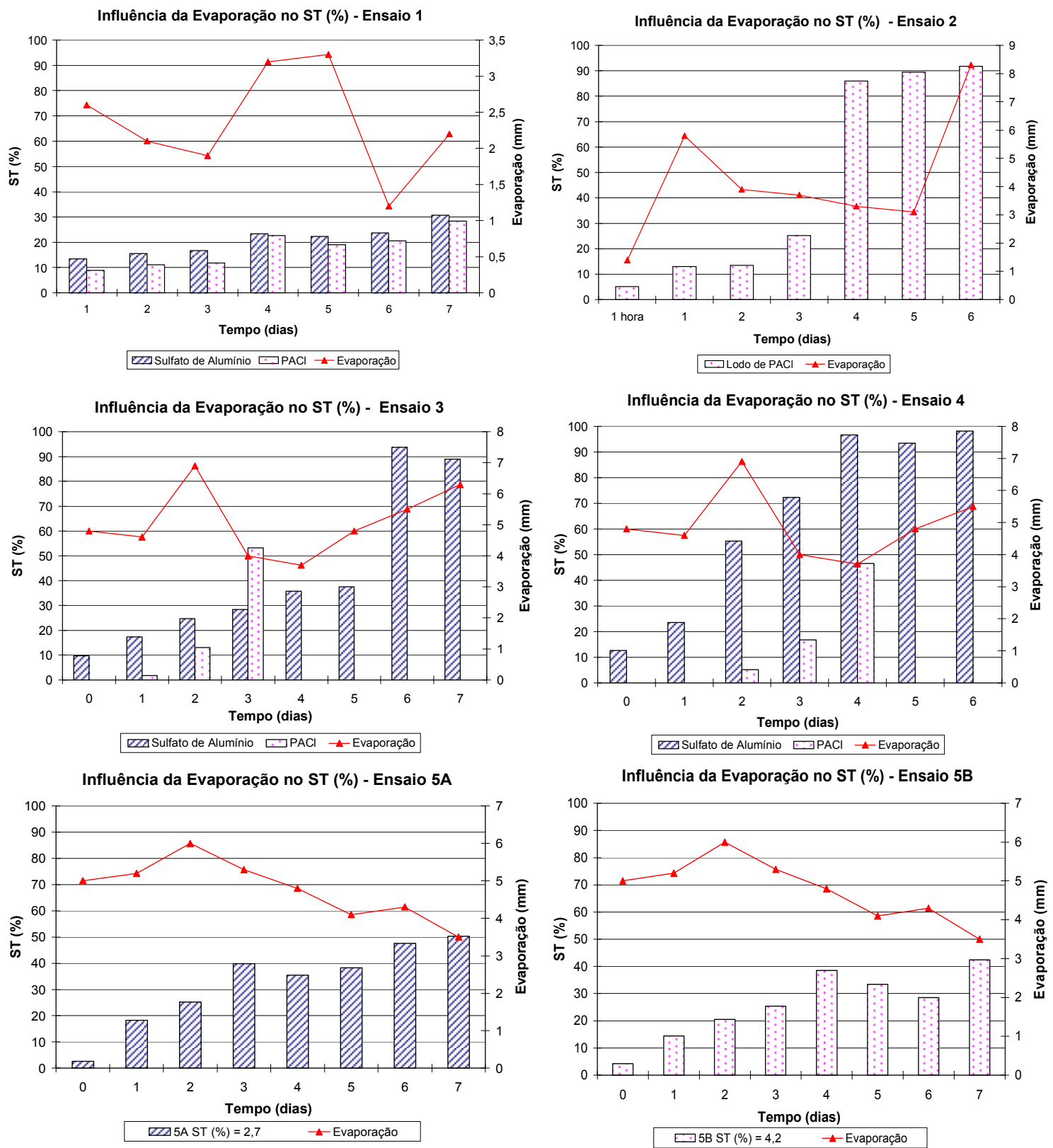

Figura 6.47 - Variação da evaporação $(\mathrm{mm})$ e do teor de sólidos totais $(\% \mathrm{ST})$ para cada ensaio de desaguamento por Leito de Drenagem (Fase de Secagem).

Na Figura 6.48 são apresentados os resultados da variação diária de vento em $\mathrm{m} / \mathrm{s}$ incidente aos leitos de drenagems usados nos ensaios de desaguamento.

A ação do vento é responsável pela movimentação do fluxo de umidade, ou seja, pela troca de umidade imediatamente superior a massa de lodo.

A curva gerada de variação diária da velocidade de vento assemelhou-se a curva de evaporação. 
A intensidade e velocidade de vento nos Ensaios 1 e 2 foram consideravelmente superiores aos resultados dos Ensaios 3, 4, 5A e 5B.

Nos Ensaios 1 e 2, os valores de vento foram superiores a $4 \mathrm{~m} / \mathrm{s}$ e os valores de teores de sólidos não ultrapassaram o valor de $30 \%$, como para o Ensaio 1, ou não foram suficientes para elevar o teor de sólidos, com no caso do Ensaio 2.

Para os Ensaios 3 e 4, os valores de velocidade de vento situaram em torno de 1,0 a 2,5 m/s. Apesar disso, a variação da curva de vento foi acompanhada pela variação do teor de sólidos das amostras de lodo desaguado. Contudo, para os Ensaios 5A e 5B, os valores de velocidade de vento situaram em torno de 1,0 a $2,5 \mathrm{~m} / \mathrm{s}$. A variação do teor de sólidos das amostras de lodo desaguado foi acompanhada pela variação da curva de vento.
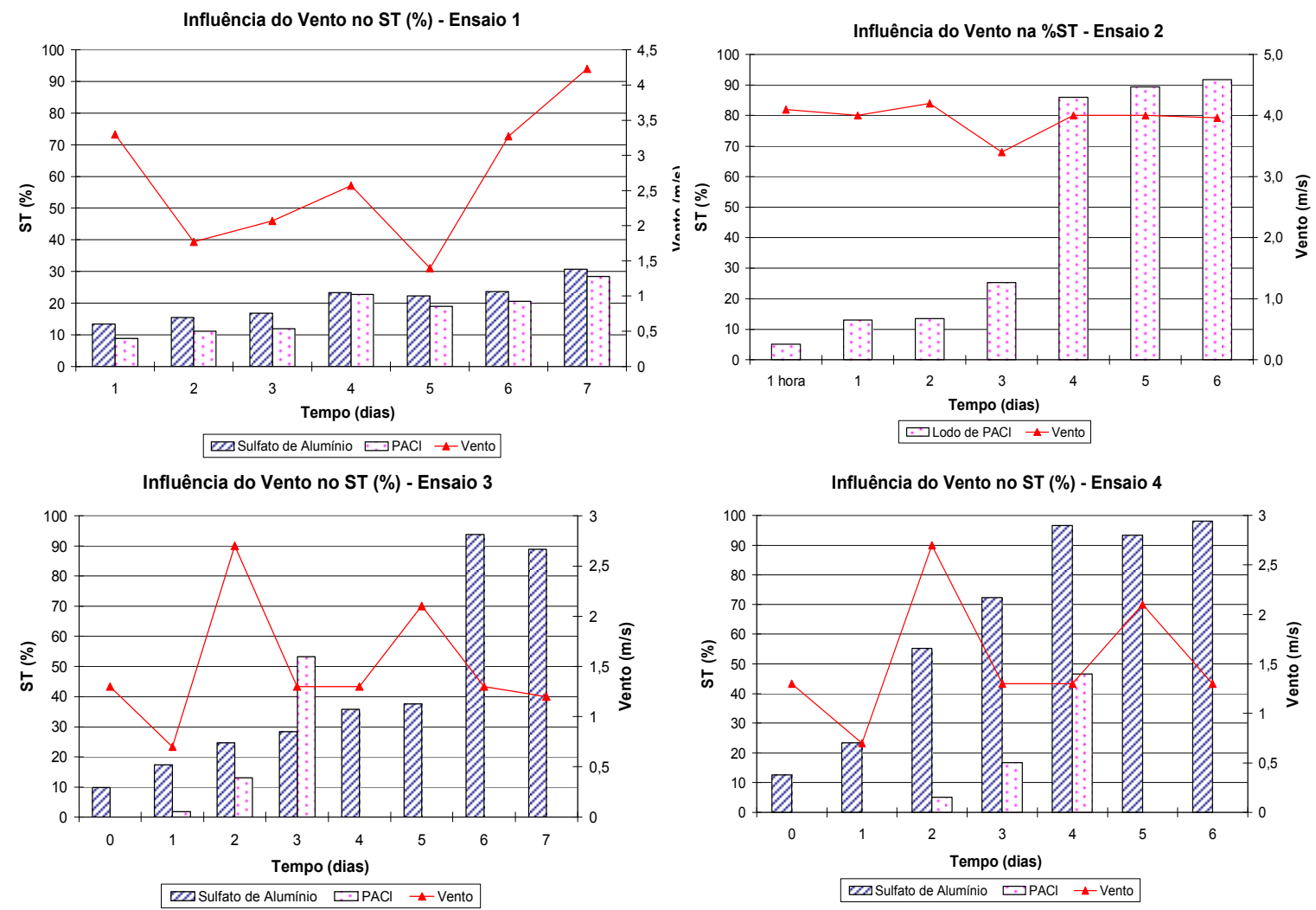

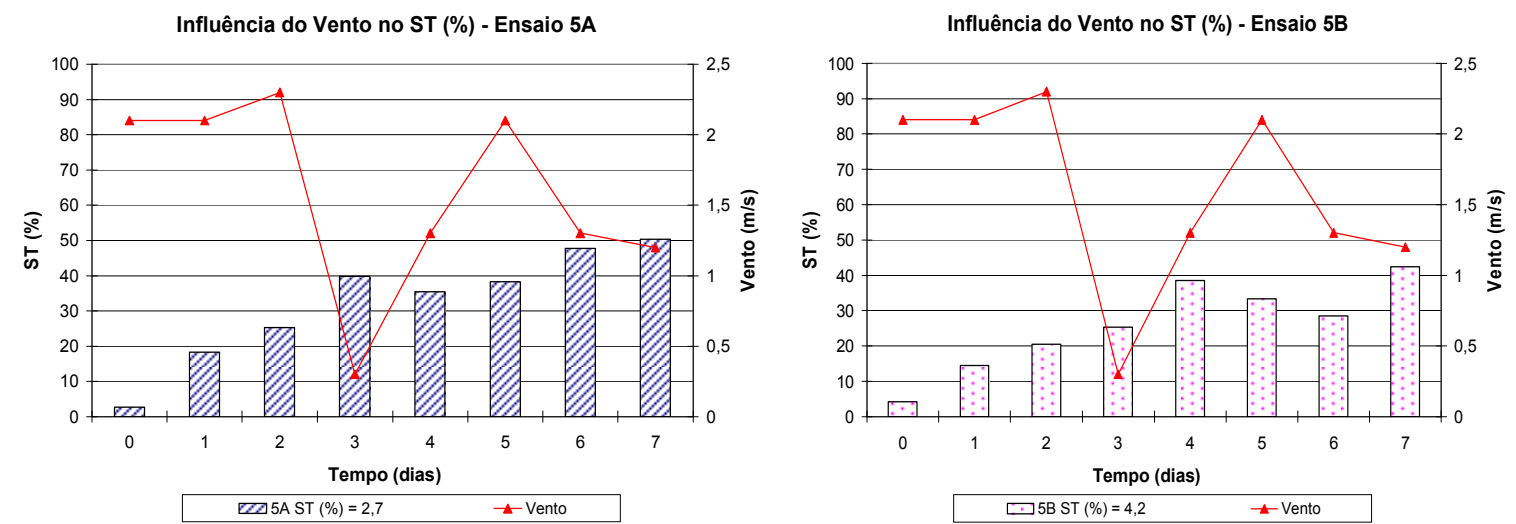

Figura 6.48 - Variação do vento $(\mathrm{m} / \mathrm{s})$ e do teor de sólidos totais $(\% \mathrm{ST})$ para cada ensaio de desaguamento por Leito de Drenagem (Fase de Secagem).

A Figura 6.49 mostra a variação da temperatura do ar durante a realização dos ensaios de desaguamento por leito de drenagem.

Os valores de temperatura do ar variaram para todos os ensaios, entre 20 e $28^{\circ} \mathrm{C}$, exceto para os Ensaios 1, 5A e 5B, em que apresentaram valores abaixo de $20^{\circ} \mathrm{C}$ nos últimos dois dias de ensaio.

A temperatura do ar pode ser considerada fundamental nos mecanismos de fluxo de massa de umidade e transmissão de energia para a massa de lodo e mostrou-se potencialmente favorável a secagem. 

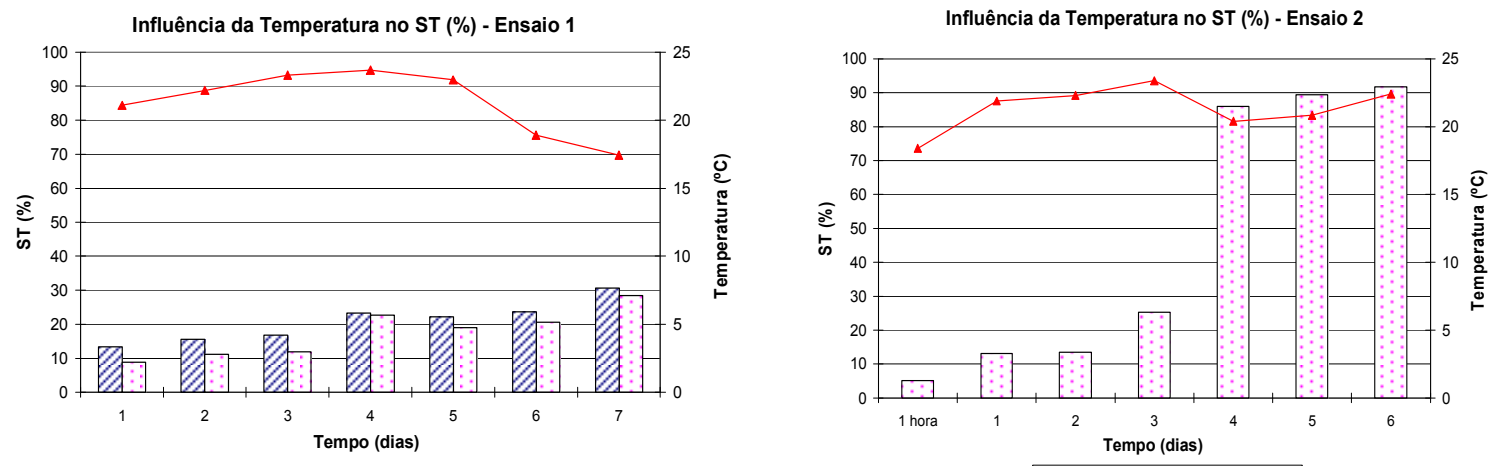

『Sulfato de Aluminio $\square \mathrm{PACl} \&$ - Temperatura

Influência da Temperatura no ST (\%) - Ensaio 3

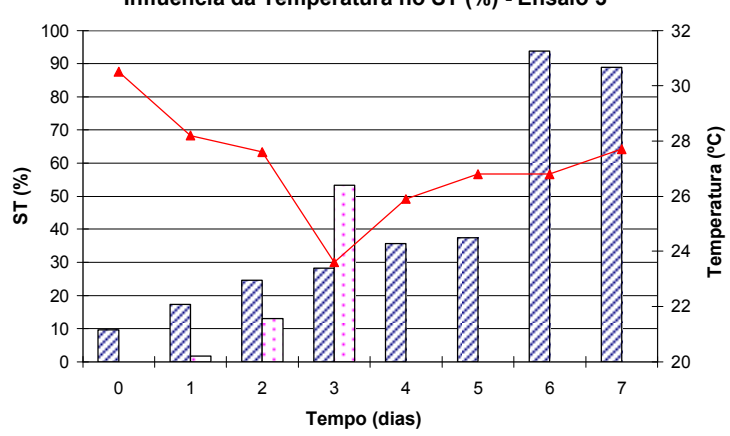

$\square$ Lodo de PACI \&-Temperatura

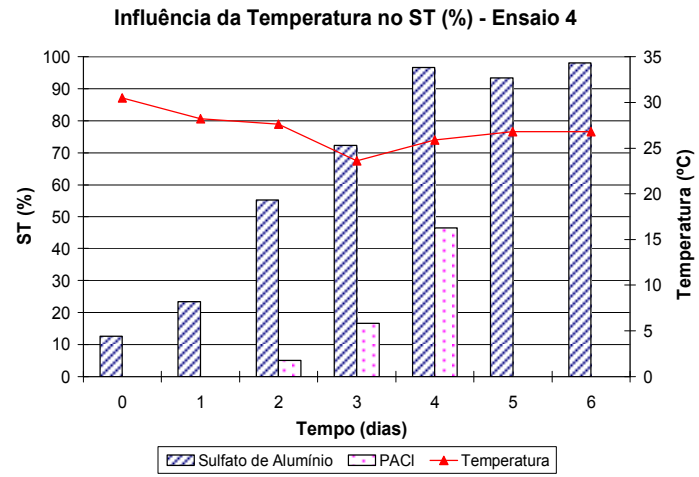

Zu Sulfato de Aluminio $\square \mathrm{PACl} \perp$ Temperatura

Influência da Temperatura no ST (\%) - Ensaio 5A
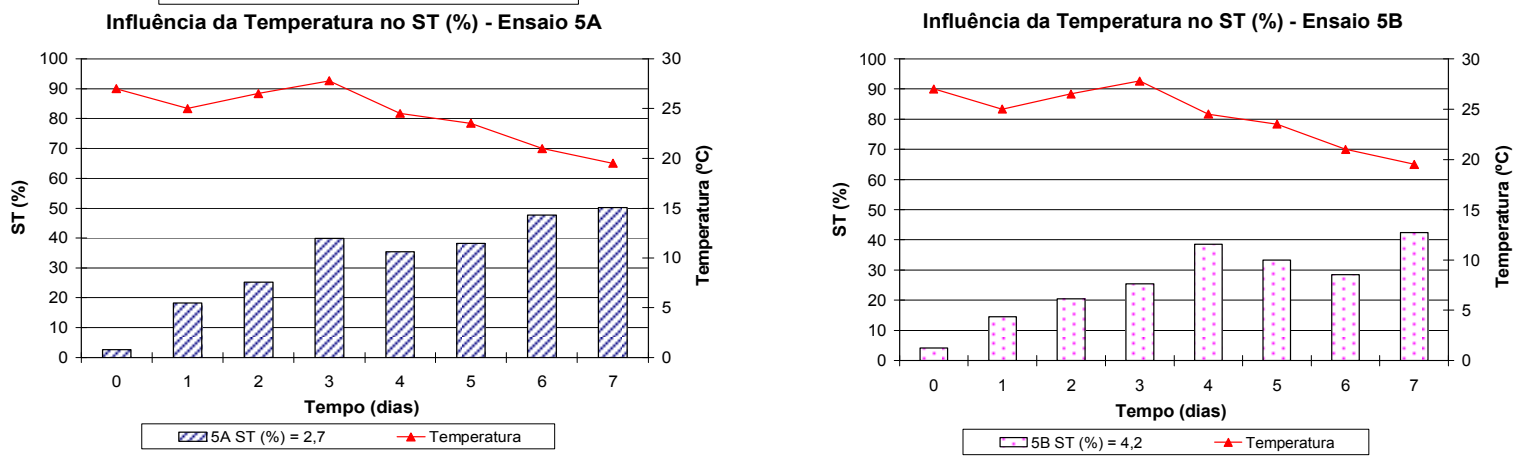

Figura 6.49 - Variação da temperatura do ar $\left({ }^{\circ} \mathrm{C}\right)$ e do teor de sólidos totais $(\% \mathrm{ST})$ para cada ensaio de desaguamento por Leito de Drenagem (Fase de Secagem).

$\mathrm{Na}$ avaliação da influência das variáveis climáticas, o autor deixa claro que as observações supracitadas a respeito possuem o caráter de anunciar indicações, portanto não se esgotam.

Há necessidade de realização de estudos específicos nesse sentido, com levantamento de mais dados de variáveis climáticas que propiciem uma análise multivariada, de maneira a compreender as relações existentes entre as variáveis, bem como os efeitos antagônicos ou sinergéticos de efeito mútuo entre as variáveis. 
A insolação assume a característica de ser determinante para outras variáveis climáticas, tais como a evaporação, temperatura e umidade relativa do ar. Além disso, a insolação pode ser considerada, prioritariamente, a fonte de energia necessária para a transmissão de calor e radiação responsável por promover o fluxo de massa da umidade da massa de lodo para o ar, (David, 2002).

A precipitação como fator isolado não mostrou-se determinante na velocidade de secagem. Porém, quando da permanência de alta umidade relativa do ar, advindo com a chuva pode prejudicar decisivamente o desempenho do desaguamento.

O cálculo da expressão fluxo de massa de água evaporada da massa de lodo permitiu realizar as seguintes observações.

Os resultados de variação diária de fluxo de água evaporada das massas de lodos evidenciaram as diferenças quanto à evolução e velocidade de secagem, para os dois tipos de lodos estudados.

Via de regra, os lodos de $\mathrm{PAC} \ell$ iniciaram com baixos valores de fluxo de massa de água evaporada e apresentam tendência crescente. Os lodos de sulfato de alumínio apresentaram comportamento inverso.

Ressalta-se mais uma vez, que os valores distintos de teor de sólidos entre os dois tipos de lodos podem ser responsáveis pelos diferentes comportamentos. Como já explicado, pode ter relação com a formação de filme líquido (mecanismos de secagem) e com a natureza, arranjo e estrutura da massa de lodo.

A compreensão dos mecanismos de secagem e dos fatores intervenientes pode contribuir para o desenvolvimento tecnológico e de projetos de Leitos de Drenagem usados para o desaguamento de lodos de ETAs. 


\subsubsection{Avaliação qualitativa dos ensaios de desaguamento por leito de drenagem - micro e macropropriedades}

A partir da avaliação das características qualitativas da fração sólida dos lodos e das mantas geotêxteis usadas nos ensaios, espera-se contribuir para compreensão dos mecanismos de secagem e, quiçá, para todo o processo de desaguamento por leito de drenagem.

Assim, são relatados os resultados das análises de microscopia eletrônica de varredura acoplada a espectroscopia por dispersão de energia de raios X (MEV-EDS), de difração de Raios X e determinação da distribuição de tamanho de partículas.

\subsubsection{Análises em amostras de lodo bruto e lodo desaguado de sulfato de alumínio e PAC $\ell$ por MEV/EDS}

A análise de Microscopia Eletrônica de Varredura acoplada a Espectroscopia por Dispersão de Energia de Raios-X (MEV-EDS) possibilitou gerar a micrografia das superfícies das amostras sólidas de lodo e a identificação qualitativa dos elementos químicos presentes nas amostras de lodos brutos e desaguados (retidos na manta).

Os resultados foram obtidos para os lodos de sulfato de alumínio (Ensaio 4) e de PACl (Ensaio 2) e são apresentados a seguir. A determinação dos constituintes químicos por EDS e difração de raios X é feito por comparação com padrões ICDD (International Centre for

Diffraction Data). Assim, buscou-se auxílio e indicação de valores encontrados na literatura brasileira na identificação qualitativa dos elementos químicos presentes em amostras de lodos de sulfato de alumínio, conforme apresentado na Tabela 6.28 . 
Tabela 6.28 - Valores dos componentes químicos, valor médio em (\% em massa) encontrados para amostras de lodo bruto de sulfato de alumínio, reportados na literatura brasileira.

\begin{tabular}{|c|c|c|c|}
\hline Componentes & $\begin{array}{c}\operatorname{Dias}(2002)^{\mathrm{c}} \\
(\%)\end{array}$ & $\begin{array}{c}\text { Oliveira (2004) } \\
(\%)\end{array}$ & $\begin{array}{c}\text { Santos et al. (2001) } \\
(\%)\end{array}$ \\
\hline $\mathrm{MgO}$ & 0,23 & 0,37 & 0,69 \\
\hline $\mathrm{Al}_{2} \mathrm{O}_{3}$ & 26,40 & 31,71 & 28,30 \\
\hline $\mathrm{SiO}_{2}$ & 27,80 & 35,92 & 34,8 \\
\hline $\mathrm{K}_{2} \mathrm{O}$ & 0,27 & 0,58 & 0,57 \\
\hline $\mathrm{CaO}$ & 0,05 & 0,10 & 0,40 \\
\hline $\mathrm{TiO}_{2}$ & 0,95 & 1,10 & 0,94 \\
\hline $\mathrm{Fe}_{2} \mathrm{O}_{3}$ & 13,50 & 12,79 & 6,60 \\
\hline $\mathrm{MnO}$ & - & 0,09 & 0,17 \\
\hline $\mathrm{Na}_{2} \mathrm{O}$ & 0,13 & 0,06 & 0,23 \\
\hline $\mathrm{P}_{2} \mathrm{O}_{5}$ & - & 0,35 & - \\
\hline $\mathrm{PF}^{*}$ & 24,50 & 16,93 & - \\
\hline
\end{tabular}

PF* - Perda ao fogo.

Para as amostras de lodo bruto e lodo desaguado (retido no leito de drenagem) de sulfato de alumínio do Ensaio 4, os resultados das micrografias (MEV) e análise qualitativa dos componentes das partículas (EDS) são apresentados, respectivamente, nas Figuras 6.50 e 6.51 

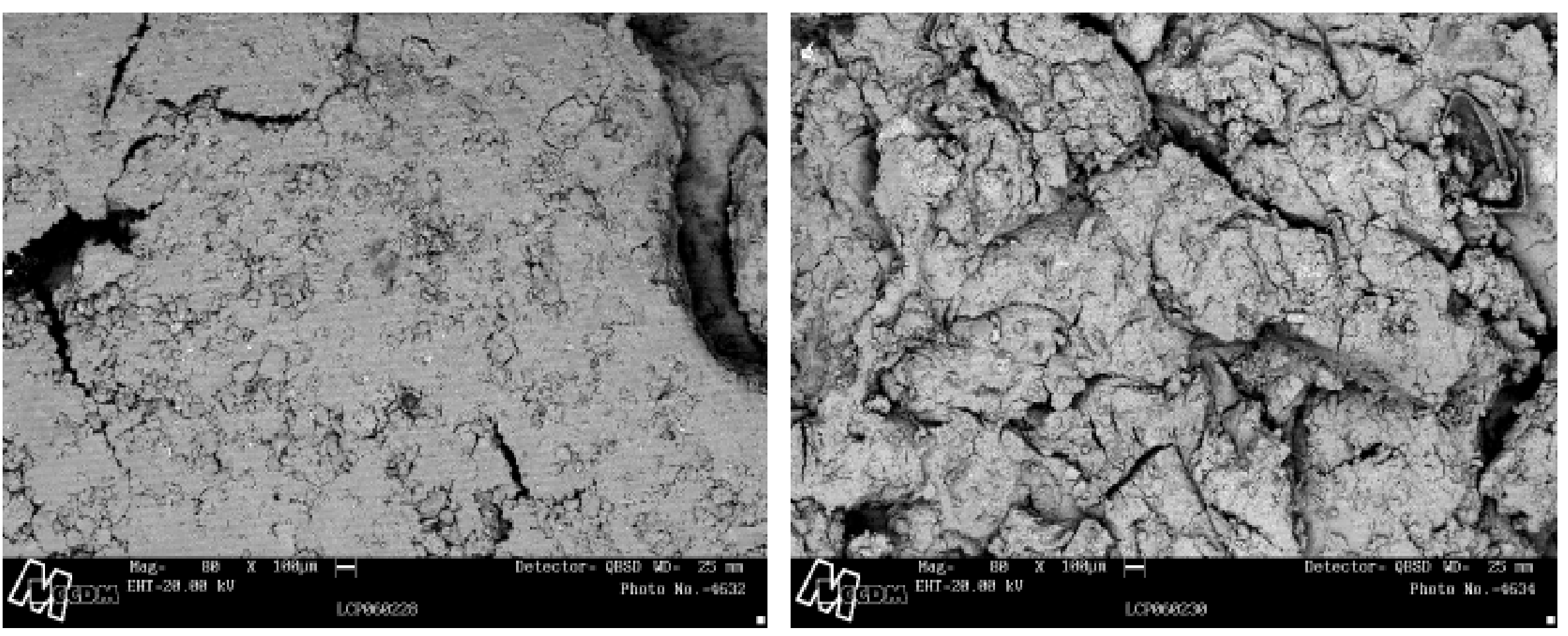

(a) amostra de lodo bruto de sulfato de alumínio.

(b) amostra de lodo desaguado de sulfato de alumínio.

Figura 6.50 - Micrografias obtidas por MEV das amostras de lodo de sulfato de alumínio do Ensaio 4. (a) micrografia de amostra de lodo bruto aplicado no Leito de Drenagem e (b) micrografia de amostra de lodo desaguado (retido na manta geotêxtil). 
A partir da Figura 6.50 observa-se que a morfologia do lodo bruto de sulfato de alumínio (a) possui superfície com aspecto regular (liso), mas de composição heterogênea de partículas com presença evidente e elevada quantidade de partículas com diâmetros em torno de $100 \mu \mathrm{m}$. Já para a amostra de lodo desaguado (b) a superfície apresenta aspecto irregular (revolvido) com vazios e aberturas. Não há presença evidente e em grande quantidade de partículas com diâmetros, cerca de $100 \mu \mathrm{m}$.

A análise qualitativa dos elementos constituintes das amostras de lodo bruto e lodo desaguado (retido na manta geotêxtil) de sulfato de alumínio é apresentada na Figura 6.51.

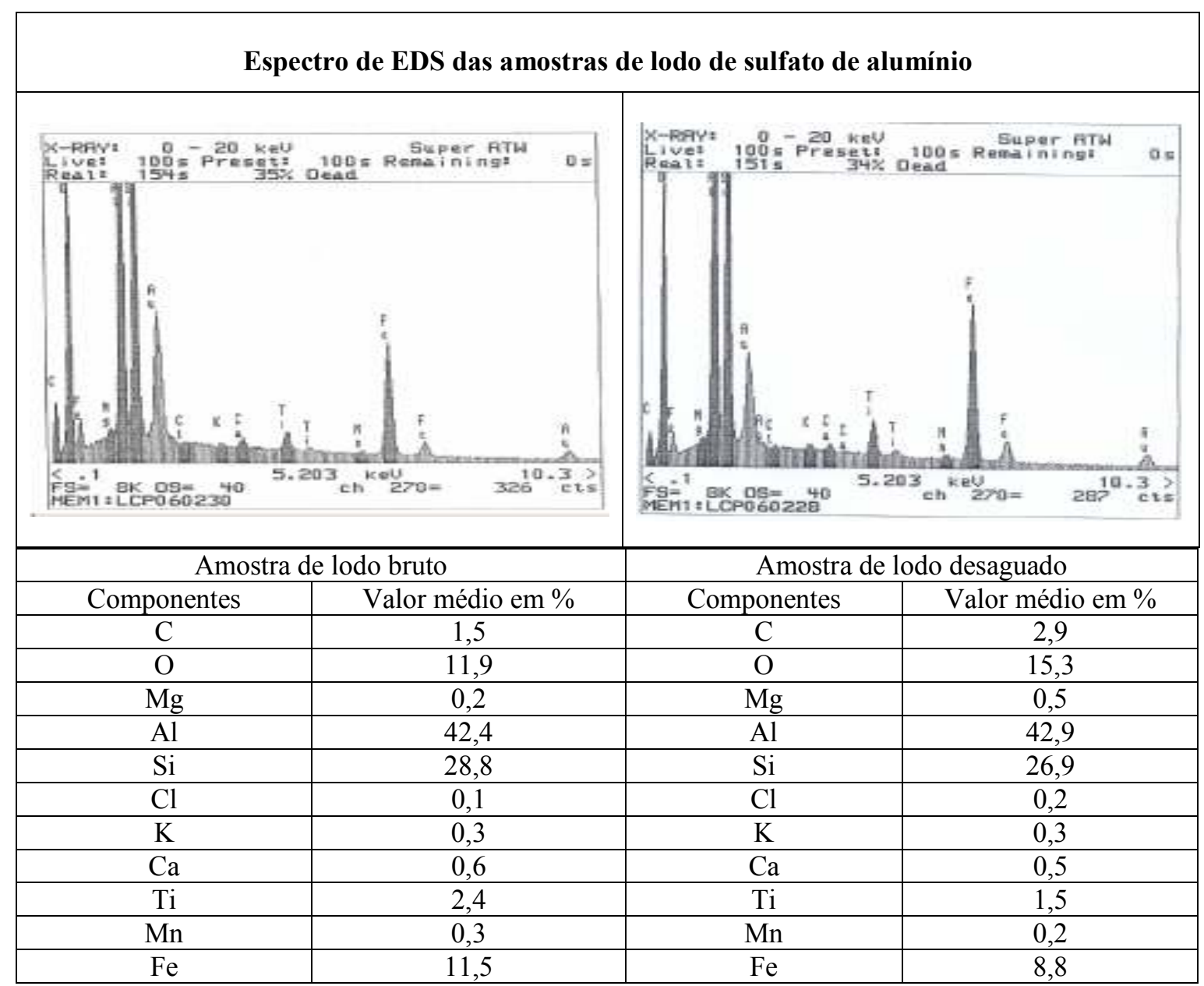

Figura 6.51 - Resultado da análise de EDS para amostras de lodo de sulfato de alumínio bruto (a) e lodo desaguado, retido no Leito de Drenagem (b). 
A Figura 6.51 mostra o predomínio dos elementos alumínio, silício e ferro nas amostras de lodo bruto e desaguado de sulfato de alumínio. Pode-se considerar que não houve variação na composição percentual para as duas amostras (a) e (b), exceto para o elemento carbono que modificou sua contribuição percentual no lodo desaguado (aumentou de 1,45 para $2,99 \%)$.

A composição predominante de Alumínio concorda com o reportado por Dias (2002), em que cita predominância de argilominerais tais como a caulinita e gibsita (compostos de Al) e quartzo (compostos com $\mathrm{Si}$ ) no lodo de sulfato de alumínio.

Salienta-se que em função do reúso, como aproveitamento em produtos cerâmicos, desejam-se lodos desaguados com alto teor de $\mathrm{Al}$ e $\mathrm{Si}$.

A confirmação exata do tipo de estrutura cristalina e mais particularmente dos argilominarais pode ser confirmado pela realização de difração de raios X.

Para as amostras de lodo bruto e lodo desaguado (retido no leito de drenagem) de PACl do Ensaio 2, os resultados das micrografias (MEV) e análise qualitativa dos componentes das partículas (EDS) são apresentados, respectivamente, nas Figuras 6.52 e 6.53 . 

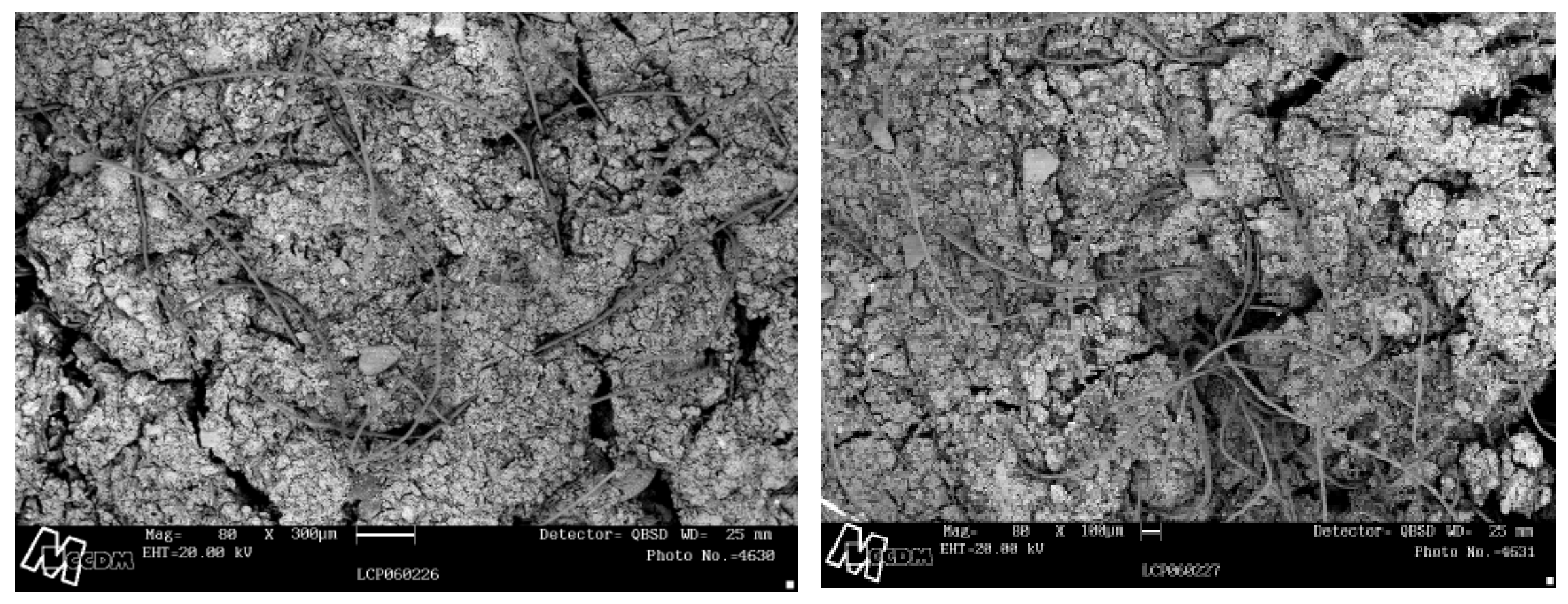

(a) amostra de lodo bruto de PACl.

(b) amostra de lodo desaguado de PACl.

Figura 6.52 - Micrografias obtidas por MEV das amostras de lodo de PACl do Ensaio 2. (a) micrografia de amostra de lodo bruto aplicado no Leito de Drenagem e (b) micrografia de amostra de lodo desaguado (retido na manta geotêxtil). 
A partir da Figura 6.52 observa-se que a morfologia do lodo bruto de $\mathrm{PAC} \ell$ (a) apresentou superfície com aspecto irregular e composição heterogênea de partículas. Mostrase elevada quantidade de partículas com diâmetros em torno de $100 \mu \mathrm{m}$. Já para a amostra de lodo desaguado a superfície evidencia a presença de vazios e aberturas. Contudo, permanece evidente a presença de partículas com diâmetro com cerca de $100 \mu \mathrm{m}$.

A análise qualitativa dos elementos constituintes, obtidas por EDS, das amostras de lodos de PACl é apresentada na Figura 6.53.

\begin{tabular}{|c|c|c|c|}
\hline \multicolumn{4}{|c|}{ Espectro de EDS das amostras de lodo de PAC $\ell$} \\
\hline \multicolumn{2}{|c|}{ 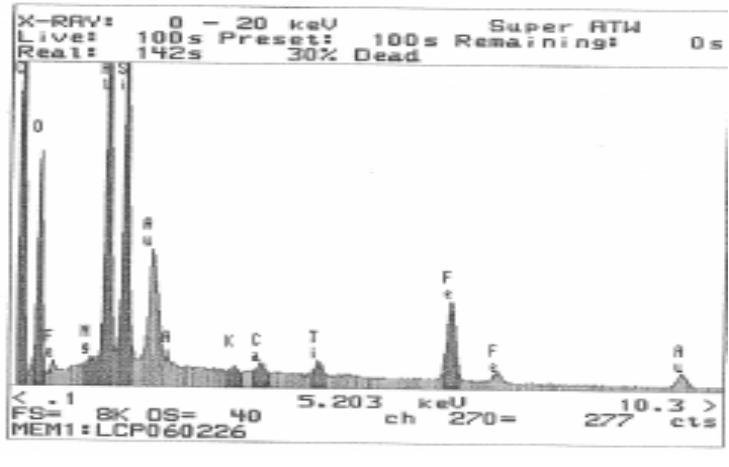 } & \multicolumn{2}{|c|}{ 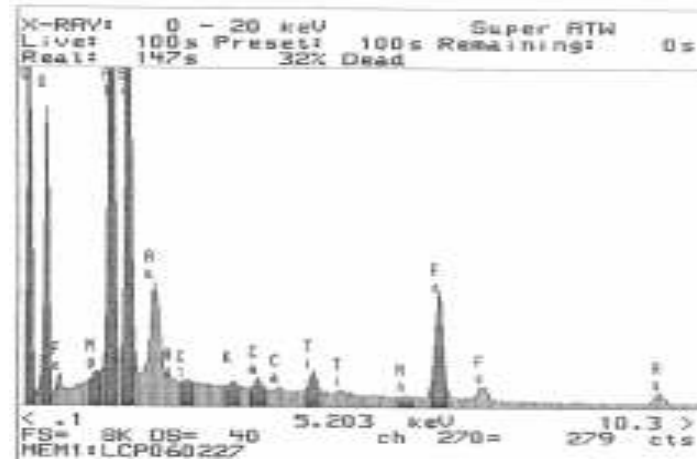 } \\
\hline \multicolumn{2}{|c|}{ Amostra de lodo bruto } & \multicolumn{2}{|c|}{ Amostra de lodo desaguado } \\
\hline Componentes & Valor médio em \% & Componentes & Valor médio em \% \\
\hline $\mathrm{C}$ & 30,7 & $\mathrm{C}$ & 17,6 \\
\hline $\mathrm{O}$ & 10,3 & $\mathrm{O}$ & 10,5 \\
\hline $\mathrm{Mg}$ & 0,3 & $\mathrm{Mg}$ & 0,2 \\
\hline $\mathrm{Al}$ & 26,7 & $\mathrm{Al}$ & 34,6 \\
\hline $\mathrm{Si}$ & 23,3 & $\mathrm{Si}$ & 27,6 \\
\hline $\mathrm{K}$ & 0,3 & $\mathrm{Cl}$ & 0,2 \\
\hline $\mathrm{Ca}$ & 0,7 & $\mathrm{~K}$ & 0,3 \\
\hline $\mathrm{Ti}$ & 1,2 & $\mathrm{Ca}$ & 0,6 \\
\hline $\mathrm{Fe}$ & 6,5 & $\mathrm{Ti}$ & 1,3 \\
\hline- & - & $\mathrm{Mn}$ & 0,2 \\
\hline- & - & $\mathrm{Fe}$ & 6,9 \\
\hline
\end{tabular}

Figura 6.53 - Resultado da análise de EDS para amostras de lodo de PAC $\ell$ bruto (a) e lodo desaguado (retida no leito de drenagem) (b). 
A Figura 6.53 mostra o predomínio dos elementos alumínio, silício, carbono e ferro nas amostras de lodo bruto (a) e desaguado (b) de PACl. Nesse caso houve variação na composição percentual entre as duas amostras (a) e (b).

O lodo desaguado de $\mathrm{PACl}$ (b) apresentou aumento percentual para os elementos $\mathrm{Al}$ (variou de 26,67 para 34,56 \%), Si (de 23,3 para 27,65 \%) e diminuição percentual de C (de 30,7 \% para 17,63\%). Além disso, "surgiu” Mn com 0,17\% e $\mathrm{Cl}$ com 0,22\%.

A constatação do aumento percentual de Al na amostra de lodo desaguado de PACl pode indicar que o desaguamento por Leito de Drenagem apresenta potencial de aproveitamento e reuso dos lodos de $\mathrm{PACl}$, tais como na produção cerâmica.

\subsubsection{Análises por MEV/EDS em amostras de manta geotêxtil usada nos ensaios de desaguamento}

Nas Figuras 6.54 e 6.55 são apresentadas, respectivamente, as micrografias de amostra da manta geotêxtil usada (lado oposto à aplicação de lodo) no Leito de Drenagem I, durante os ensaios de desaguamento de lodos de sulfato de alumínio e de manta geotêxtil virgem (manta não usada). As micrografias foram obtidas em regiões distintas das mantas geotêxteis de poliéster, com aumentos de 50 e 250x (vezes). 


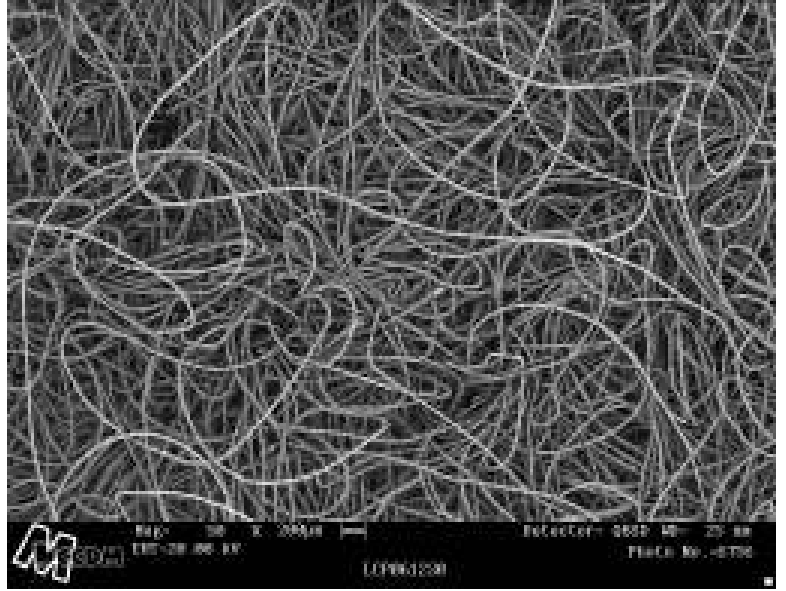

(a)

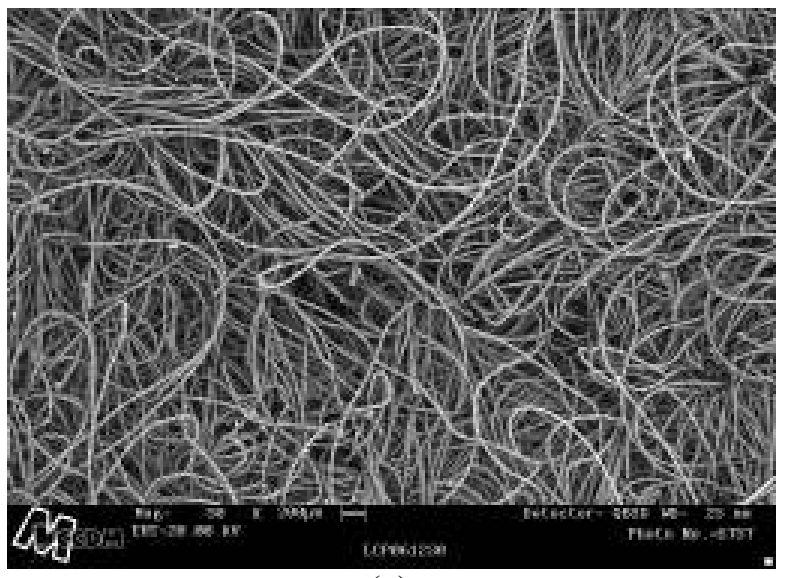

(c)

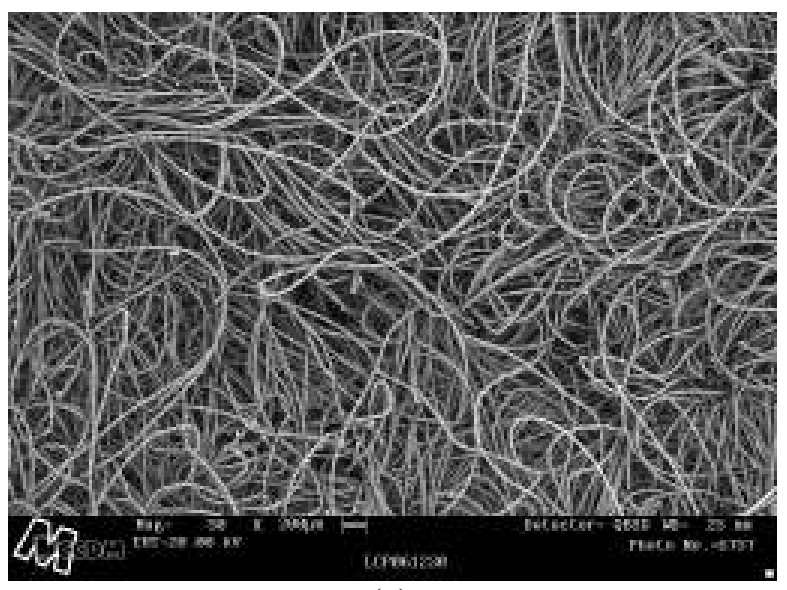

(e)

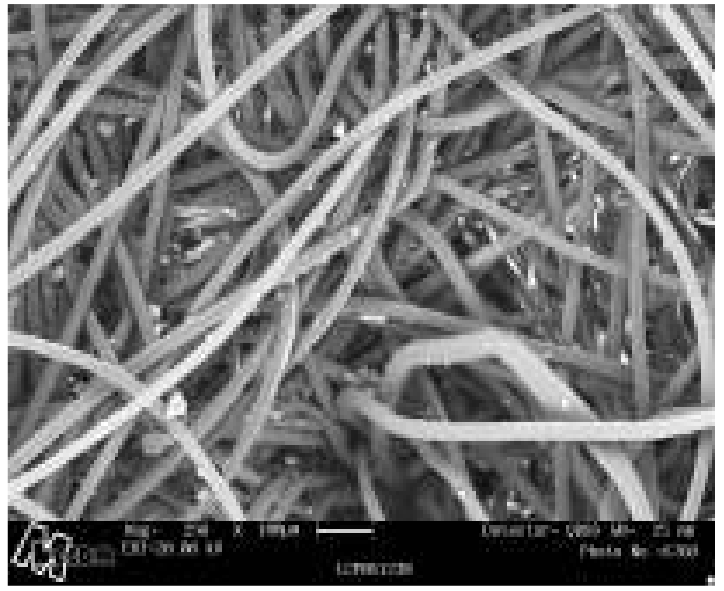

(b)

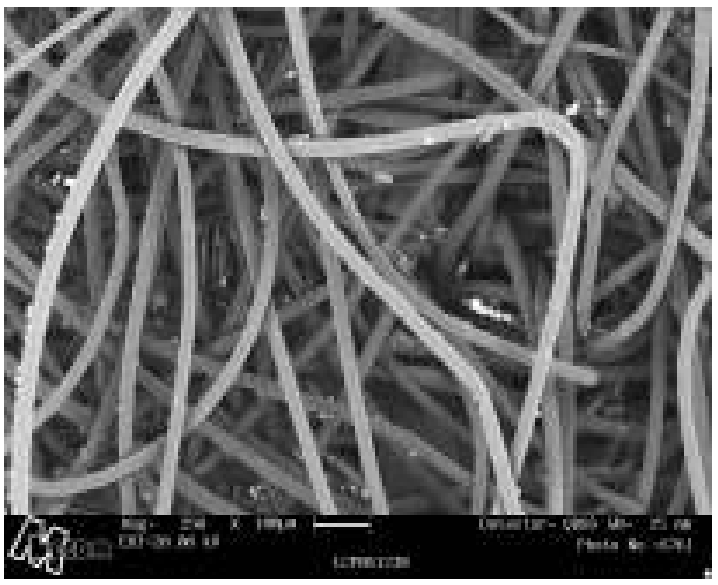

(d)

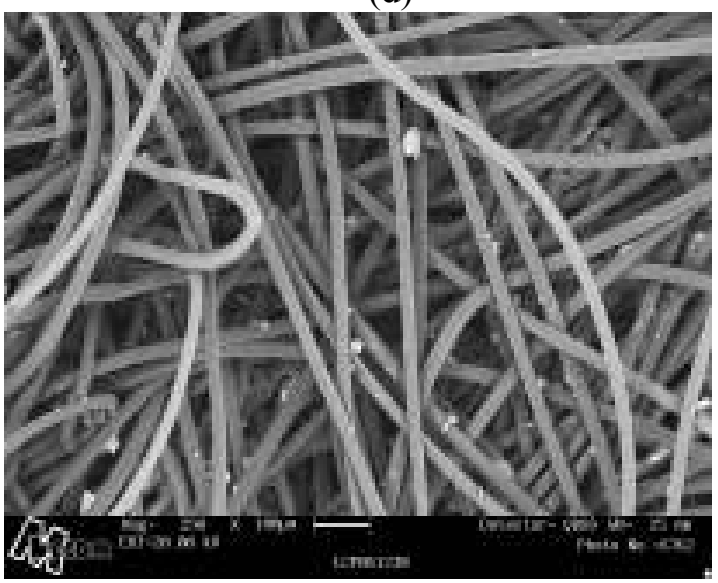

(f)

Figura 6.54 - Micrografias da amostra de manta geotêxtil usada. Vista do lado oposto à aplicação de lodo de sulfato de alumínio. (a), (c) e (e) aumento de 50x e (b), (d) e (f) aumento de 250x. 
As micrografias da Figura 6.54 fornecem uma vista geral da manta geotêxtil não tecida e mostra a disposição aleatória das fibras. Há vários pontos claros localizados sobre e entre as fibras das mantas usadas nos ensaios de desaguamento. Estes pontos claros são partículas de morfologia irregular, cujo tamanho pode variar entre 5 e $50 \mu \mathrm{m}$.

Os resultados dos elementos químicos identificados nestas partículas, obtidos a partir de análises de EDS são apresentados na Tabela 6.29. Os elementos químicos foram considerados majoritários quando detectados nas cargas acima de 10\%, minoritários entre 1 e $10 \%$ e elementos traços abaixo de $1 \%$.

Tabela 6.29 - Elementos químicos identificados por EDS nas partículas encontradas na amostra de manta geotêxtil usada nos ensaios de desaguamento de lodo de sulfato de alumínio por Leito de Drenagem.

\begin{tabular}{c|c|c|c}
\hline \multirow{2}{*}{ Tipo de amostra } & \multicolumn{3}{|c}{ Elementos químicos } \\
\cline { 2 - 4 } & Majoritários & Minoritários & Traços \\
\hline Partículas & $\mathrm{C}, \mathrm{Al}, \mathrm{Si}, \mathrm{Fe}$ & $\mathrm{O}, \mathrm{Ti}$ & $\mathrm{Mg}, \mathrm{K}, \mathrm{Ca}$ \\
\hline
\end{tabular}

As partículas analisadas (Tabela 6.29) apresentaram altas concentrações de alumínio, silício (estes dois elementos podem estar na forma de algum aluminossilicato) e ferro. Titânio (possivelmente como dióxido de titânio) foi determinado como elemento minoritário.

Em outra partícula analisada foram determinados praticamente os mesmos elementos químicos, porém a concentração de cálcio (possivelmente como carbonato de cálcio) estava acima de 10\%, caracterizando-o assim, como elemento majoritário.

As micrografias da amostra de manta geotêxtil virgem (lado oposto à aplicação de lodo) estão apresentadas na Figura 6.55. 


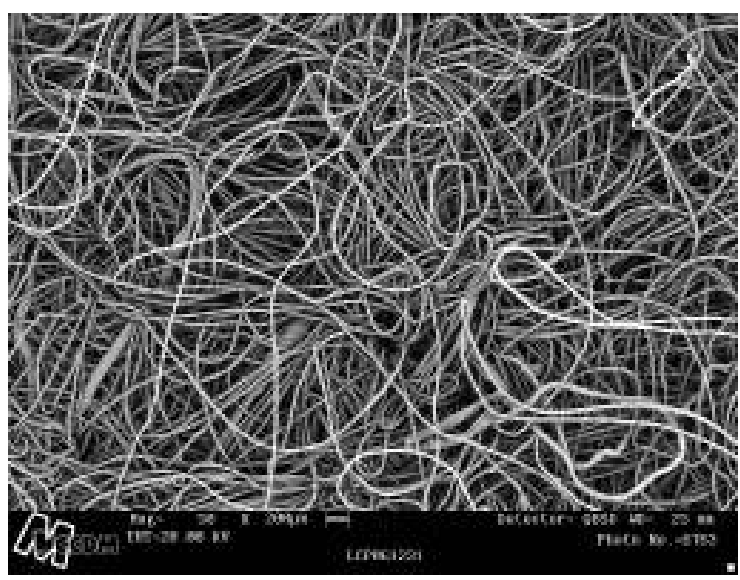

(a)

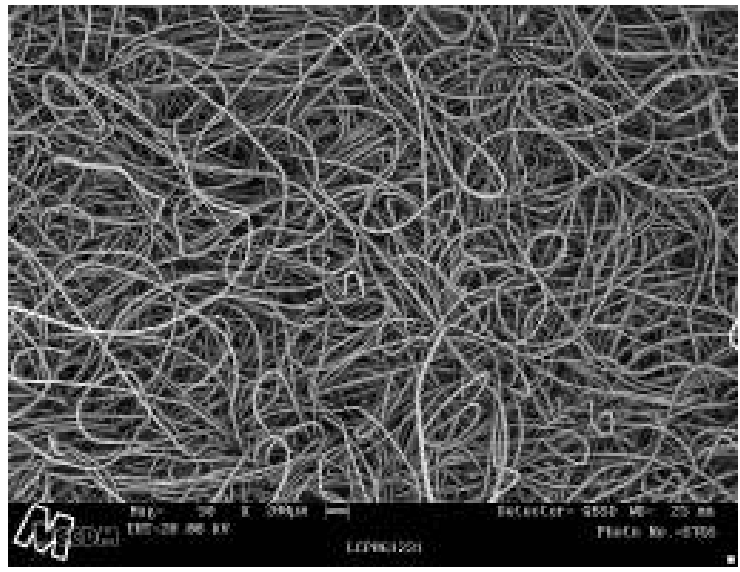

(c)

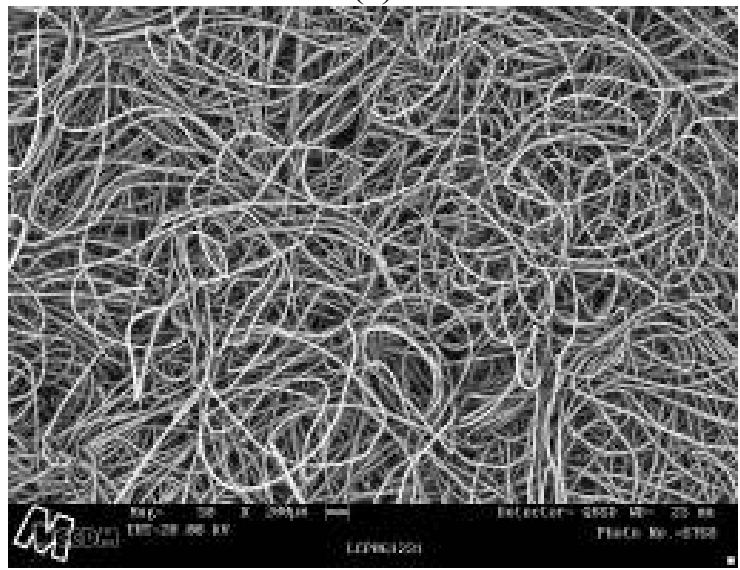

(e)

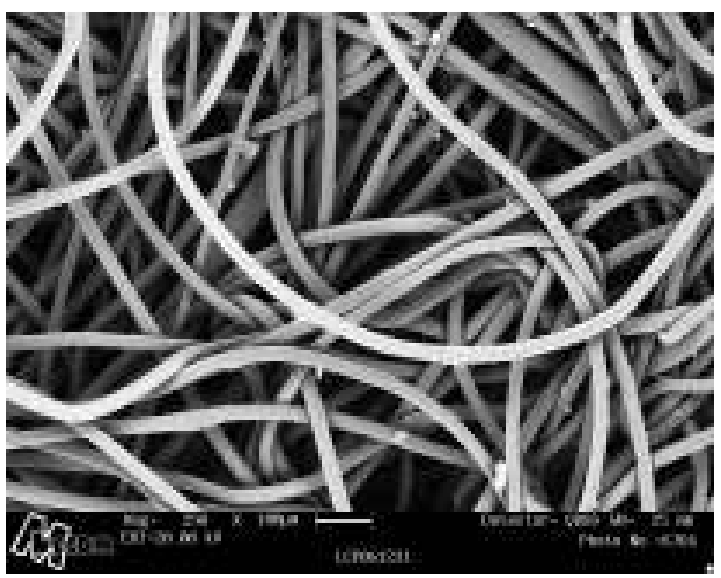

(b)

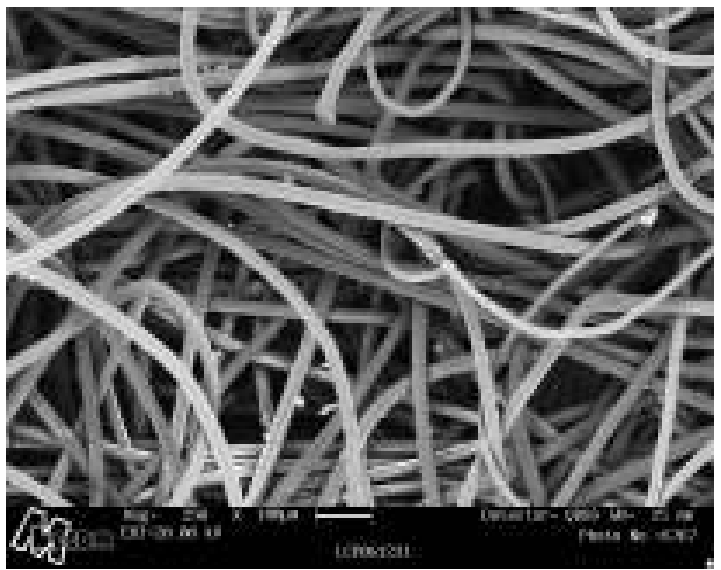

(d)

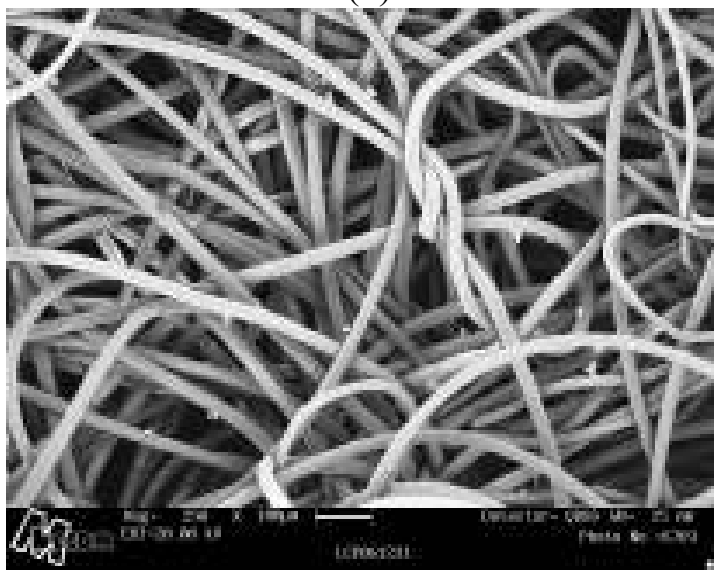

(f)

Figura 6.55 - Micrografias da amostra de manta geotêxtil virgem, (a), (c) e (e) aumento de $50 x$ e (b), (d) e (f) aumento de 250x.

A amostra de manta geotêxtil virgem apresentou algumas partículas sobre suas fibras (Figura 6.55). Entretanto, a quantidade destas partículas é menor que a observada na amostra de manta geotêxtil usada. 
O tamanho destas partículas está entre 5 e $25 \mu \mathrm{m}$ e foram analisadas por EDS. A Tabela 6.30 apresenta os elementos químicos identificados nestas partículas.

Tabela 6.30 - Elementos químicos identificados por EDS nas partículas encontradas na amostra de manta geotêxtil virgem (não usada).

\begin{tabular}{c|c|c|c}
\hline \multirow{2}{*}{ Tipo de amostra } & \multicolumn{3}{|c}{ Elementos químicos } \\
\cline { 2 - 4 } & Majoritários & Minoritários & Traços \\
\hline Partículas & $\mathrm{C}$ & $\mathrm{O}, \mathrm{Al}, \mathrm{Si}, \mathrm{Ca}$ & $\mathrm{Mg}, \mathrm{Cl}, \mathrm{K}, \mathrm{Ti}, \mathrm{Fe}$ \\
\hline
\end{tabular}

As partículas analisadas (Tabela 6.30) são ricas em alumínio, silício e carbonato de cálcio. Também foi encontrado partícula com maior concentração de ferro (em porcentagem característica de elemento minoritário) e de cálcio (em porcentagem característica de elemento majoritário).

\subsubsection{Análises em amostras de lodo bruto e lodo desaguado de sulfato de alumínio e PAC $\ell$ por Difração de Raios $X$}

A análise de Difração de raios X possibilitou a análise mineralógica qualitativa das amostras de lodos de sulfato de alumínio e de PACl.

$\mathrm{O}$ difratograma de raios $\mathrm{X}$ das amostras de lodo bruto e desaguado de sulfato de alumínio e de PAC $\ell$ estão apresentadas em conjunto na Figura A1, em Anexo.

$\mathrm{Na}$ Tabela 6.31 são apresentados os resultados de identificação mineralógica qualitativa dos elementos químicos presentes nas amostras de lodos brutos e desaguados de sulfato de alumínio e de $\mathrm{PAC} \ell$ obtidos pela analise de difração de raios X. 
Tabela 6.31 - Valores dos componentes químicos, valor médio em (\% em massa) encontrados para lodo de $\mathrm{PACl}$ e sulfato de alumínio (Difração de Raios X).

\begin{tabular}{c|c|c|c|c}
\hline \multirow{2}{*}{ Composição } & \multicolumn{2}{|c|}{ Lodo de sulfato de alumínio } & \multicolumn{2}{c}{ Lodo de PACl } \\
\cline { 2 - 5 } & $\begin{array}{c}\text { Lodo bruto } \\
\text { LSC1 (\%) }\end{array}$ & $\begin{array}{c}\text { Lodo desaguado } \\
\text { LSC2 (\%) }\end{array}$ & $\begin{array}{c}\text { Lodo bruto } \\
\text { LPAC1 (\%) }\end{array}$ & $\begin{array}{c}\text { Lodo desaguado } \\
\text { LPAC2 (\%) }\end{array}$ \\
\hline $\begin{array}{c}\text { Caulinita } \\
\left(\mathrm{Al}_{2} \mathrm{Si}_{2} \mathrm{O}_{5}(\mathrm{OH})_{4}\right) .\end{array}$ & 6,97 & 8,38 & 9,47 & 9,37 \\
\hline $\begin{array}{c}\mathrm{Gibsita} \\
\left(\mathrm{Al}(\mathrm{OH})_{3}\right)\end{array}$ & 11,81 & 11,15 & - & - \\
\hline $\begin{array}{c}\text { Quartzo } \\
\left.(\mathrm{SiO})_{2}\right)\end{array}$ & 8,3 & 8,58 & - & - \\
\hline $\begin{array}{c}\mathrm{Hematita} \\
\left(\mathrm{F}_{2} \mathrm{O}_{3}\right)\end{array}$ & - & - & 6,14 & 8,33 \\
\hline
\end{tabular}

O difratograma de raios $\mathrm{X}$ para as amostras de lodos de sulfato de alumínio bruto (LSC1) e desaguado (LSC2) é apresentado na Figura 6.56.

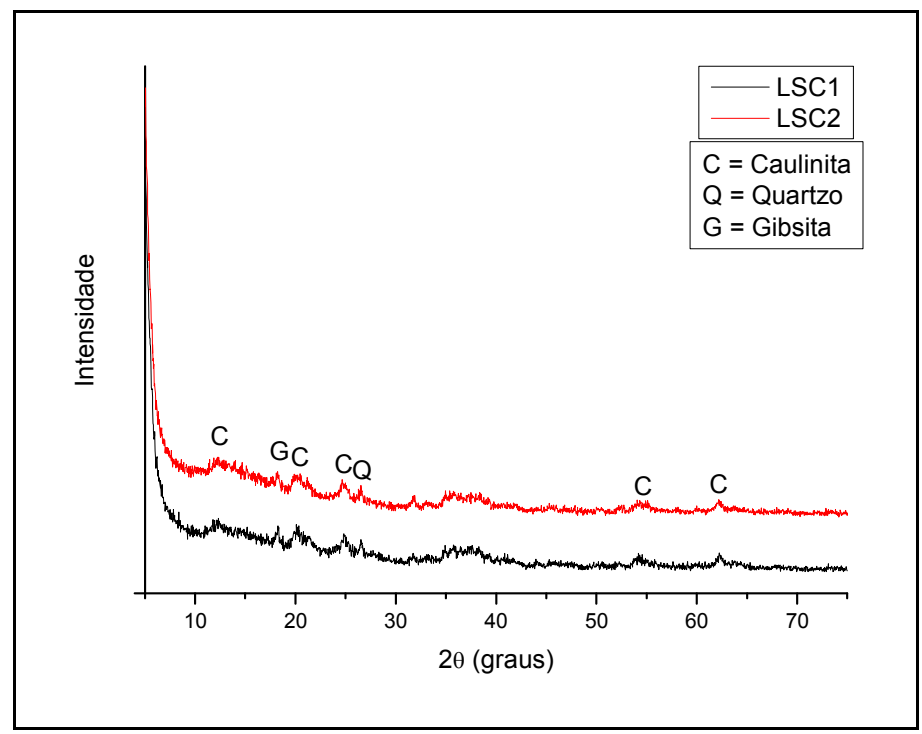

Figura 6.56 - Difratograma de raios $\mathrm{X}$ das amostras de lodo de sulfato de alumínio bruto (LSC1) e lodo desaguado (LSC2).

A Figura 6.56 mostra picos de difração de baixa intensidade para as duas amostras analisadas. Contudo, os picos são característicos das fases cristalinas referentes aos 
argilominerais caulinita $\left(\mathrm{Al}_{2} \mathrm{Si}_{2} \mathrm{O}_{5}(\mathrm{OH})_{4}\right)$, gibsita $\left(\mathrm{Al}(\mathrm{OH})_{3}\right)$ e quartzo $\left(\mathrm{SiO}_{2}\right)$. Os resultados estão de acordo com as avaliações reportadas na literatura brasileira.

No lodo bruto de sulfato de alumínio (LSC1), os principais constituintes químicos foram: $\mathrm{Al}_{2} \mathrm{Si}_{2} \mathrm{O}_{5}(\mathrm{OH})_{4} \operatorname{com} 6,97 \%, \mathrm{Al}(\mathrm{OH})_{3} 11,81 \%$ e $\mathrm{SiO}_{2} .8,3 \%$. Nas amostras de lodo desaguado de sulfato de alumínio os principais elementos foram os mesmos e variaram pouco as porcentagens: $8,38 \%$ de $\mathrm{Al}_{2} \mathrm{Si}_{2} \mathrm{O}_{5}(\mathrm{OH})_{4}, 11,15 \%$ de $\mathrm{Al}(\mathrm{OH})_{3}$ e $8,58 \%$ de $\left(\mathrm{SiO}_{2}\right)$, como pode ser observado na Tabela 6.32 .

Portanto, as indicações apontadas pela análise de MEV/EDS foram confirmadas destacando a presença predominante de argilominerais. Salienta-se mais uma vez, o potencial de reutilização dos lodos de sulfato de alumínio estudados, devido à presença de caulinita e gibsita em sua composição.

As amostras de lodos de $\mathrm{PACl}$ também geraram difratogramas com picos de difração de baixa intensidade (Figura 6.57). A Figura 6.57 mostra picos de difração característicos das fases cristalinas referentes à hematita $\left(\mathrm{F}_{2} \mathrm{O}_{3}\right)$ e a caulinita $\left(\mathrm{Al}_{2} \mathrm{Si}_{2} \mathrm{O}_{5}(\mathrm{OH})_{4}\right)$.

No lodo bruto de PACl (LPAC1), os principais constituintes químicos foram: $\mathrm{F}_{2} \mathrm{O}_{3}$ com $6,14 \%$ e $\mathrm{Al}_{2} \mathrm{Si}_{2} \mathrm{O}_{5}(\mathrm{OH})_{4}$ com 9,47\%. Nas amostras de lodo desaguado de PACl, os principais elementos foram os mesmos, variando pouco as porcentagens: $8,33 \%$ de $\mathrm{F}_{2} \mathrm{O}_{3}$ e $9,37 \%$ de $\mathrm{Al}_{2} \mathrm{Si}_{2} \mathrm{O}_{5}(\mathrm{OH})_{4}$, como pode ser observado na Tabela 6.31 .

Interessante observar a presença de ferro e ausência de outros argilominerais, a base de alumínio. A presença do elemento ferro pode indicar potencial de aproveitamento para uso na cerâmica vermelha. 


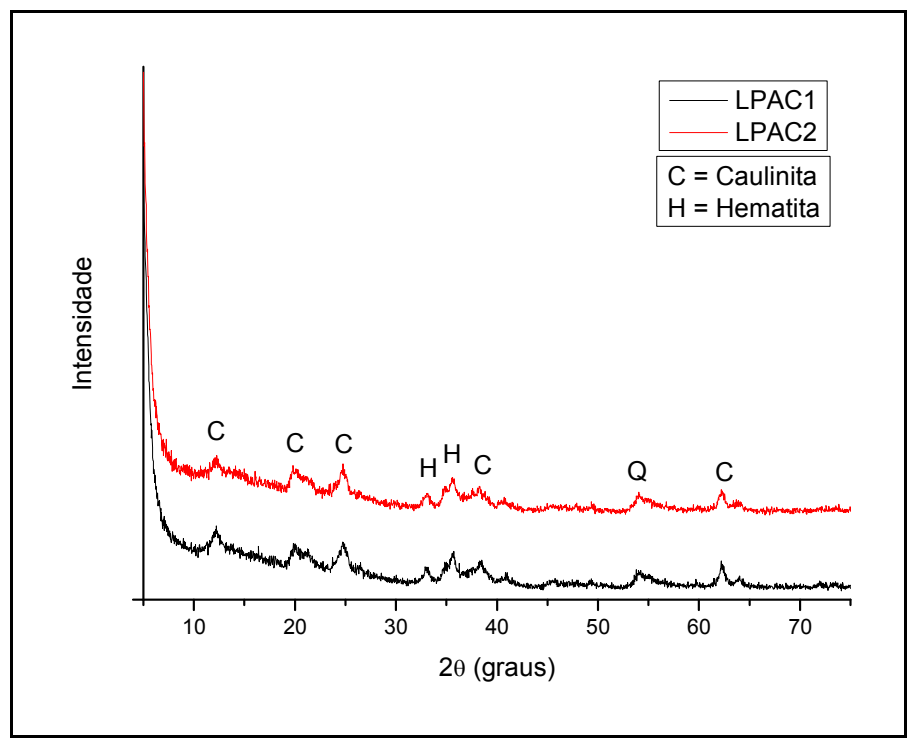

Figura 6.57 - Difratograma de raios X das amostras de lodo de PAC $\ell$ bruto (LPAC1) e lodo desaguado (LPAC2).

Com a realização das análises de difração de raios $\mathrm{X}$, confirmou-se a presença majoritária de argilominerais, principalmente a caulinita para os dois tipos de lodos estudados. Mais uma vez, ressalta-se que os argilominerais compreendem tamanho de partículas na faixa de $2 \mu \mathrm{m}$, a ser confirmada nas determinações de distribuição de tamanho de partículas. A presença de outros argilominerais não foi observada. Porém, os difratogramas apresentaram picos com baixa intensidade que pode apontar a necessidade de preparo de amostras calcinadas de lodos de sulfato de alumínio e de PACl.

A tendência de aumento relativo de alumínio na composição percentual dos lodos desaguados não se mostrou evidente, conforme indicava os resultados das análises de EDS. Não se pode negligenciar o fato que a diminuição elevada do percentual de carbono no lodo desaguado, seja "compensado" pelo aparente aumento percentual de alumínio na composição dos lodos de ETAs. Entretanto, pesquisas específicas são necessárias para esclarecimento dos comportamentos aqui observados. 
Os resultados de EDS e difração de raios $\mathrm{X}$ indicaram elevado teor de carbono em determinadas amostras e, indiretamente a migração de carbono através do leito de drenagem. Nesse sentido, algumas considerações podem ser enunciadas.

A composição majoritária de carbono e em alguns caso de cálcio pode concorrer para colmatação química da manta geotêxtil e pode contribuir nos mecanismos de retenção de partículas destacadamente menores que as aberturas das mantas.

De maneira geral, os resultados das micrografias obtidas por MEV nas amostras das mantas geotexteis (usada e não usada) mostraram a retenção de partículas muito pequenas, bem menores que a abertura de filtração da manta geotêxtil usada nos Leito de Drenagem.

Tal constatação evidenciou ocorrência de dois mecanismos de retenção das partículas, a autofiltração e a formação de uma rede de arcos, conforme cita Freitas (2003).

$\mathrm{Na}$ autofiltração, a ação de filtro não se restringiu apenas a manta geotêxtil, mas propagou-se à camada adjacente, formando uma espécie de pré-filtro.

Por outro lado, as partículas retidas adjacentes às aberturas superficiais, tendem a redistribuir as tensões verticais devido à força de percolação e força da gravidade, e pode formar arcos que dificultam a passagem de partículas com diâmetros menores que das aberturas. A presença desses arcos pode ser confirmada por análise de imagens. Porém, no desenvolvimento dessa pesquisa não foi possível a realização dessas imagens.

O contraste entre o tamanho das partículas retidas e a abertura do poro da manta geotêxtil também permite inferir nos mecanismo de colmatação da manta.

Salienta-se que as causas da colmatação podem ser físicas, químicas ou químicobiológicas e em determinadas situações podem ocorrer simultaneamente.

A causa física da colmatação apresenta-se em três formas distintas denominadas bloqueamento, cegamento e colmatação propriamente dita, conforme cita Freitas (2003). Nas 
mantas geotexteis usadas nos ensaios de desaguamento podem ter ocorrido essas três formas de colmatação, mas com intensidades diferentes.

O uso contínuo das mantas não foi acompanhado de significativa colmatação levando a crer na predominância da colmatação propriamente dita, em que partículas com diâmetros próximos e/ou menores às aberturas do geotêxtil migram junto com o fluido percolante, penetram no geotextil e ficam retidas no seu interior ao longo da espessura. Estas partículas retidas no interior da espessura da manta podem ser removidas eventualmente em função da tensão de cisalhamento atuante promovendo, muitas vezes, uma colmatação branda. Adicionalmente, pode ter ocorrido colmatação por causa química, como no caso da formação de cristais resultante de carbonatos e sulfatos dissolvidos no fluido que atravessa o geotextil e que ocupam os espaços vazios nos meios porosos, quando a água evapora sob condições atmosféricas.

Assim, os mecanismos de retenção de partículas, por autofiltração e pela formação de uma rede de arcos, combinados com os mecanismos de colmatação, por causa química e física de predominância da forma "propriamente dita" podem ser responsáveis pela efetividade do leito de drenagem em reter partículas muito menores que as aberturas dos poros das mantas geotêxteis.

Por outro lado, os resultados das análises de MEV/EDS e difração de raios-X para as amostras de lodos brutos e desaguados de sulfato de alumínio e de $\mathrm{PACl}$ indicaram a melhora do potencial de reutilização do lodo após o desaguamento no leito de drenagem, uma vez que mostrou o aumento percentual de alumínio nas amostras de lodo desaguado, principalmente de lodo de PACl. Contudo são necessários mais estudos específicos.

Os resultados também permitiram visualizar a constituição da estrutura cristalina, principalmente quanto aos tipos de argilominerais predominantes, tais como a presença de 
caulinita e montmorilinita que influenciam na composição das frações de água contidas no lodo e por conseqüência na dificuldade em drenagem e secagem.

Salienta-se que os argilominerais comumente encontrados nos lodos de ETAs (sulfato de alumínio) como, por exemplo, a caulinita (presença de Al) geralmente apresentam tamanho de partículas $<2,0 \mu \mathrm{m}$ (Oliveira, 2004). O referido autor enfatiza que quanto maior a fração de partículas com tamanho menor que 2,0 $\mu \mathrm{m}$, mais rico é o lodo do ponto de vista de reuso e aproveitamento cerâmico.

Assim, a confirmação dos percentuais predominantes de argilominerais encontrados nas amostras de lodos de sulfato de alumínio e de PACl pode ser obtida pelos resultados de distribuição de tamanho de partículas.

\subsubsection{Distribuição de tamanho de partículas nas amostras de lodo de sulfato de alumínio e de PACl}

As Figuras 6.58 e 6.59 apresentam, respectivamente, os resultados de determinação de distribuição de tamanho de partículas nas amostras dos lodos brutos e desaguados de sulfato de alumínio e de $\mathrm{PACl}$.

As amostras analisadas dos lodos brutos e desaguados de sulfato de alumínio e de PACl apresentaram uma larga distribuição de tamanho de partículas, compreendida entre 0,2 a $100 \mu \mathrm{m}$.

As amostras dos lodos de sulfato de alumínio, bruto e desaguado, apresentaram elevado teor de partículas abaixo de $2 \mu \mathrm{m}$, característico da fração argila-argilominerais (Figura 6.58). 


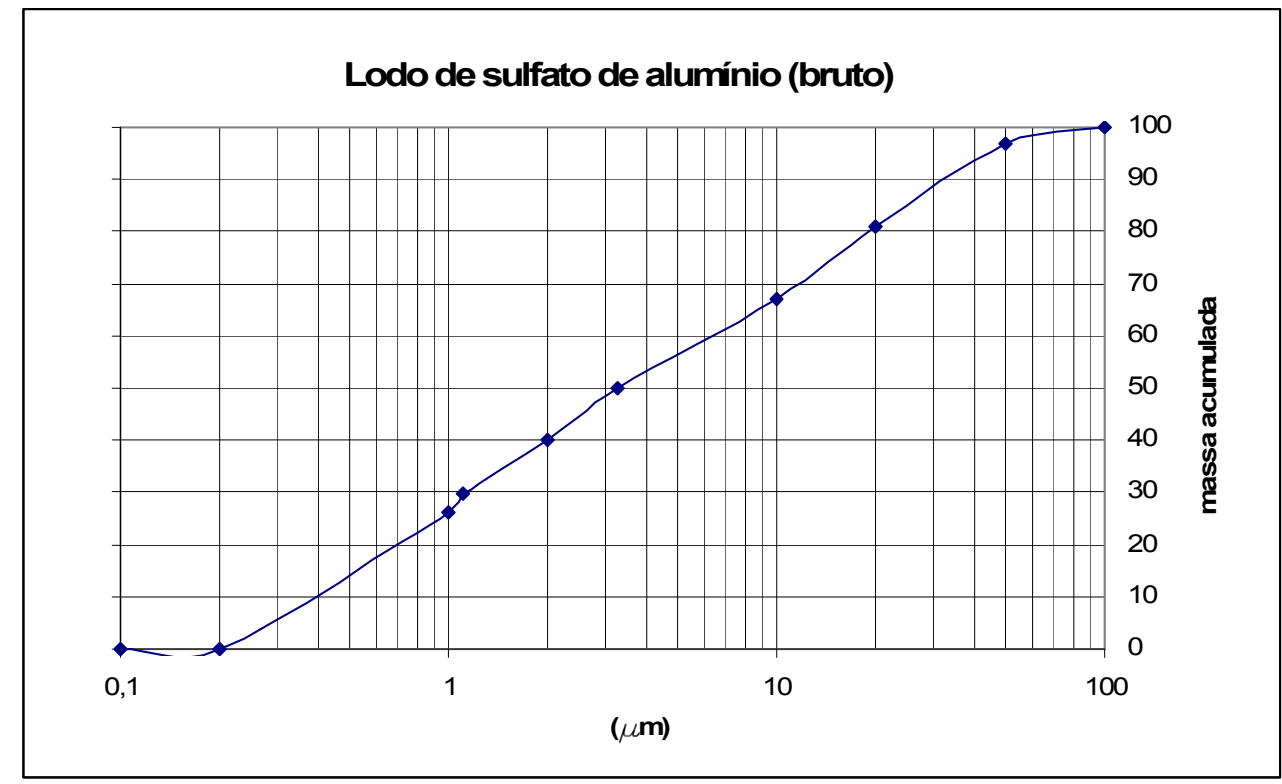

(a)

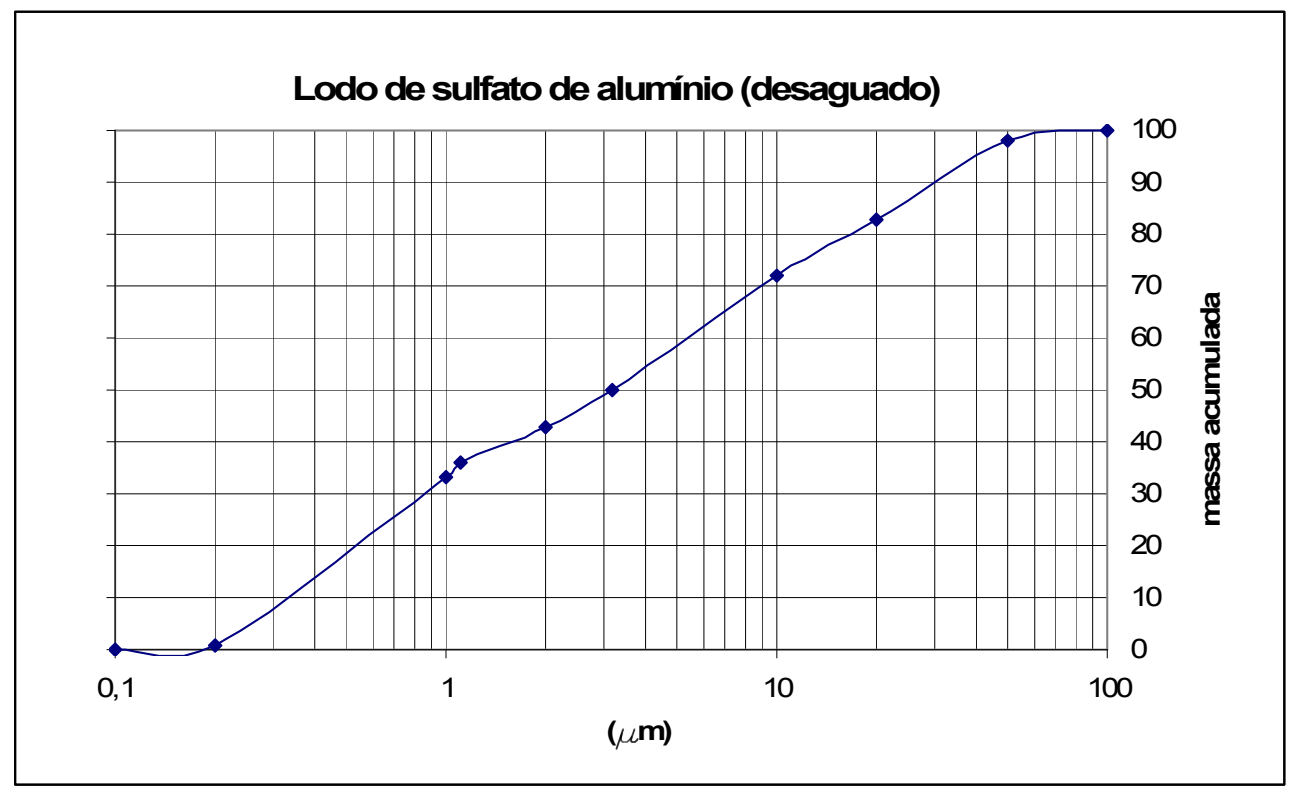

(b)

Figura 6.58 - Curva de distribuição de tamanho de partículas em massa acumulada que passa (\%) por diâmetro de esfera equivalente $(\mu \mathrm{m})$ para amostra bruta de lodo de sulfato de alumínio (a) e amostra de lodo desaguado de sulfato de alumínio (b), (Ensaio 4). 
No lodo desaguado, a porcentagem de partículas abaixo de $2 \mu \mathrm{m}$ foi ligeiramente maior, cerca de $43 \%$ que no lodo bruto, 40\%. A elevação percentual da fração de argilominerais (partículas menores que $2 \mu \mathrm{m}$ ) no lodo desaguado foi mostrada indiretamente pelos resultados das análises de MEV/EDS e difração de raios X.

Para as amostras de lodo de $\mathbf{P A C l}$, os resultados de determinação da distribuição de tamanho de partículas são apresentados na Figura 6.59.

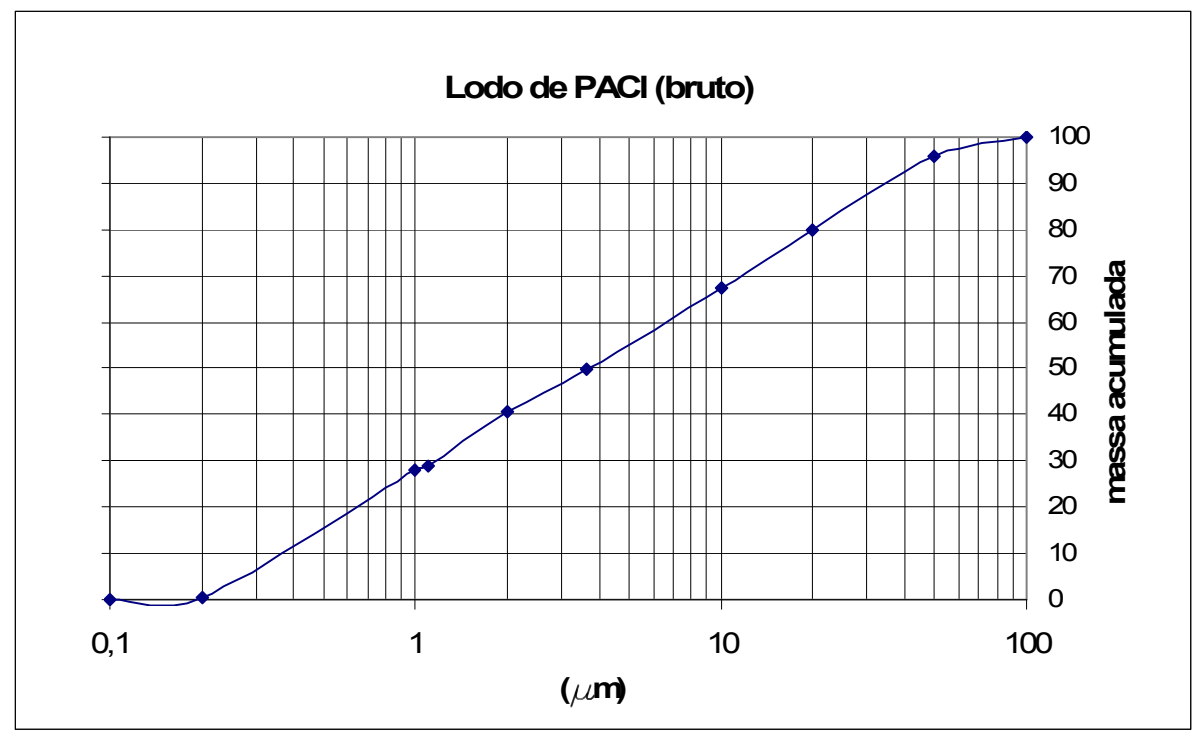

(a)

Figura 6.59 - Curva de distribuição de tamanho de partículas em massa acumulada que passa (\%) por diâmetro de esfera equivalente $(\mu \mathrm{m})$ para amostra bruta de lodo de PACl (a) e amostra de lodo desaguado de $\mathrm{PACl}$ (Ensaio 4).

As curvas de distribuição de tamanho de partículas para os distintos lodos, sulfato de alumínio e de $\mathrm{PAC} \ell$ apresentaram valores muito próximos.

Tal aspecto pode indicar que as diferenças observadas na Fase de Drenagem, quanto a velocidade de drenagem e qualidade da água drenada, estão mais relacionadas com a morfologia ou arranjo das partículas (micrografias por MEV/EDS) ou com a fração volumétrica de partículas (taxa de aplicação de sólidos/teor de sólidos). 
Estas características, aliadas a composição química das amostras de lodos podem conferir propriedades reológicas distintas e conseqüentemente comportamentos diferentes durante os ensaios de desaguamento.

Por outro lado, há de considerar as limitações do método de análise SEDIGRAPH, no que tange à não determinação de tamanho de partículas floculentas atuantes durante a sedimentação e drenagem das asmostras de lodos aplicadas no Leito de Drenagem.

Nas análises de distribuição de tamanho de partículas também foram fornecidas as densidades, com valor aproximado de $2,48 \mathrm{~g} / \mathrm{cm}^{3}$ para os dois tipos de lodos. O valor da densidade das partículas das amostras de lodos concorda com a predominância de argilominerais, caulinita $\left(2,58 \mathrm{~g} / \mathrm{cm}^{3}\right)$, quartzo $\left(2,70 \mathrm{~g} / \mathrm{cm}^{3}\right)$ e gibsita $\left(2,42 \mathrm{~g} / \mathrm{cm}^{3}\right)$.

Os resultados mostraram que cerca de $80 \%$ das partículas estão abaixo de $20 \mu \mathrm{m}$ (Figura 6.58 e 6.59). O valor médio de tamanho de partícula, ou seja, $50 \%$ das partículas apresentam diâmetros de esfera equivalente menores que 3,3 $\mu \mathrm{m}$ para lodo de sulfato de alumínio, 3,2 $\mu \mathrm{m}$ lodo de sulfato de alumínio desaguado e 3,7 $\mu \mathrm{m}$ para lodo de PACl.

A Tabela 6.32 foi construída a partir das curvas de distribuição de tamanho de partículas para os lodos de sulfato de alumínio e $\mathrm{PACl}$ e apresenta comparativamente resultados para lodo de sulfato de alumínio relatados na literatura brasileira, (Morita, 2002; Cordeiro, 2001). A comparação deve ser feita com ressalvas devido a possíveis diferenças no preparo e análise das amostras. 
Tabela 6.32 - Valores de distribuição de tamanho de partículas para lodos de sulfato de alumínio e PACl (bruto e desaguado) e valores correspondentes reportados no Brasil.

Massa acumulada de partículas com diâmetro de esfera equivalente (\%)

\begin{tabular}{|c|c|c|c|c|c|c|c|}
\hline \multirow{2}{*}{$\begin{array}{l}\text { Diâmetro } \\
\text { equivalente } \\
(\mu \mathrm{m})\end{array}$} & \multicolumn{3}{|c|}{ Amostras do Ensaio 2 e 4} & \multicolumn{4}{|c|}{ Reportados na literatura brasileira* } \\
\hline & $\begin{array}{l}\text { Lodo de } \\
\mathrm{Al}_{2} \mathrm{SO}_{4}\end{array}$ & $\begin{array}{l}\text { Lodo } \\
\text { desaguado } \\
\text { de } \mathrm{Al}_{2} \mathrm{SO}_{4}\end{array}$ & $\begin{array}{l}\text { Lodo de } \\
\text { PACl }\end{array}$ & $\begin{array}{l}{ }^{\mathrm{a}} \text { Lodo de } \\
\mathrm{Al}_{2} \mathrm{SO}_{4} \\
\text { (I) }\end{array}$ & $\begin{array}{l}{ }^{\mathrm{a}} \text { Lodo de } \\
\mathrm{FeCl}_{3}\end{array}$ & $\begin{array}{l}{ }^{\mathrm{a}} \text { Lodo de } \\
\mathrm{Al}_{2} \mathrm{SO}_{4} \\
\text { (II) }\end{array}$ & $\begin{array}{l}{ }^{\mathrm{b}} \text { Lodo } \\
\text { de } \mathrm{FeCl}_{3}\end{array}$ \\
\hline$<2,0$ & 40 & 43 & 40 & 28 & 20 & 21 & 3 a 6 \\
\hline$<10$ & 68 & 72 & 68 & 70 & 45 & 58 & - \\
\hline$<20$ & 80 & 84 & 81 & 59 & 42 & 61 & 63 a 74 \\
\hline 2,0 a 20 & 40 & 41 & 41 & 59 & 42 & 61 & 60 a 68 \\
\hline
\end{tabular}

(I) lodo de sulfato de alumínio da ETA Rio Claro

(II) lodo de sulfato de alumínio da ETA São Carlos

*Fonte: a - retirado de Cordeiro (2001); b - Morita (2002).

De maneira geral, os lodos estudados apresentaram partículas majoritariamente abaixo de $20 \mu \mathrm{m}$, com parcela considerável na faixa entre 2,0 a $20 \mu \mathrm{m}$ e outra parte com diâmetro menor que 2,0 $\mu \mathrm{m}$. Contudo, os resultados mostraram-se diferenciados dos valores encontrados na literatura, principalmente para as frações de partículas menores que 2,0 $\mu \mathrm{m}$. Os lodos estudados apresentaram valores em torno de 40 a $43 \%$, enquanto na literatura encontra-se entre 20 a $28 \%$ (Cordeiro, 2001) e de 3 a $6 \%$ (Morita, 2002).

Mais uma vez, os resultados mostraram que a presença de finos foi maior para o lodo desaguado em relação às amostras de lodo bruto. Com relação a tendência de elevação da fração de partículas mais finas $(<2,0 \mu \mathrm{m})$ nas amostras de lodo desaguado podem ser feitas algumas considerações.O autor sugere que tal aspecto pode ter relação com a sedimentação diferencial entre partículas maiores e menores.

As partículas maiores (diâmetro equivalente maior que $10 \mu \mathrm{m}$ ) apresentam elevada velocidade de sedimentação, estas sedimentam rapidamente e ficam inicialmente retidas na 
superficie e no interior da malha da manta conforme mostrou as micrografias obtidas por MEV ou ainda são arrastados junto com a água drenada.

Parte das partículas menores (diâmetro equivalente menor que $10 \mu \mathrm{m}$ ) é carreada junto com a água drenada e a outra parte, com baixa velocidade de sedimentação e livre da força de arraste da água drenada, é depositada e acumulada sobre a malha da manta geotêxtil e sobre a camada natural de partículas maiores funcionando como leito filtrante. Contudo são necessários estudos mais específicos para elucidação dos mecanismos.

Por outro lado, há de considerar as limitações da técnica usada de distribuição de tamanho de partículas. Pois, o método de análise SEDIGRAPH baseia-se na sedimentação de partículas discretas (Equação de Stokes) e não permite a determinação de tamanho das partículas floculentas que atuam durante a sedimentação e drenagem (fase de drenagem) no desaguamento por leito de drenagem.

\subsubsection{Considerações e conclusões parciais.}

Os resultados apresentados e discutidos neste capítulo possibilitam realizar as seguintes observações.

Os valores de velocidade de sedimentação máxima apresentaram diferenças substanciais entre as amostras de lodo de sulfato de alumínio e de lodo de PACl. Para as amostras de lodo sulfato de alumínio $\left(\mathrm{ST}_{\mathrm{o}}=2,60 \% ; \mathrm{ST}_{\mathrm{o}}=7,60 \% ; \mathrm{ST}_{\mathrm{o}}=0,76 \% ; \mathrm{ST}_{\mathrm{o}}=2,70\right.$ $\% ; \mathrm{ST}_{\mathrm{o}}=4,20 \%$ ), a maior velocidade de sedimentação máxima foi menor que $3,5 \mathrm{~mL} / \mathrm{min}$. Já nas amostras de lodo de PAC $\ell\left(\mathrm{ST}_{\mathrm{o}}=1,40 \% ; \mathrm{ST}_{\mathrm{o}}=0,22 \% ; \mathrm{ST}_{\mathrm{o}}=0,04 \% ; \mathrm{ST}_{\mathrm{o}}=0,26 \% ; \mathrm{ST}_{\mathrm{o}}\right.$ $=0,28 \% ; \mathrm{ST}_{\mathrm{o}}=0,21 \%$ ), a menor velocidade de sedimentação máxima foi de $13 \mathrm{~mL} / \mathrm{min}$. Os valores de concentração de sólidos mostraram-se determinantes na definição da velocidade de sedimentação das amostras de lodo de sulfato de alumínio e de PAClestudados. 
Na Fase de Drenagem foi constatado que independente do tipo (sulfato de alumínio e $\mathrm{PACl}$ ) e volume de lodo aplicado no Leito de Drenagem, a vazão de drenagem foi maior quanto menor foi o valor da taxa de aplicação de sólidos - TAS $\left(\mathbf{k g} / \mathbf{m}^{2}\right)$ e secundariamente menor teor de sólidos. Além disso, para a fase de drenagem podem ser feitas as seguintes considerações:

- Para todos os ensaios realizados neste trabalho, considerando as distintas condições de ensaio (volume de amostra aplicado, concentração, TAS, espécie de protótipo), o tempo de drenagem, Td para o lodo de sulfato de alumínio foi $T d<8$ horas e para o lodo de $\mathrm{PACl}, T d<60 \mathrm{~min}$. A redução de volume (Vtd/Vaplicado) foi maior que $50 \%$ para os lodos de sulfato de alumínio e maior que $74 \%$ para os lodos de PACl.

- De maneira geral, a água drenada de lodo de sulfato de alumínio apresentou baixos valores de cor e turbidez, cerca de $80 \%$ do volume drenado com turbidez $<20 \mathrm{uT}$, enquanto a água drenada de lodo de $\mathrm{PACl}$ apresentou comparativamente valores mais elevados. Contudo, a qualidade da água drenada obtida no desaguamento dos dois tipos de lodos estudados pode ser considerada boa, face a efetiva remoção de sólidos.

- O leito de drenagem mostrou-se efetivo na remoção de metais, sólidos, cor e turbidez. No que diz respeito às variáveis cor e turbidez os valores considerados “elevados" encontrados para a água drenada de lodo de $\mathrm{PACl}$, ainda sim, apresentaram valores equivalentes a águas superficiais usadas para produção de água potável.

A Fase de Secagem evoluiu de maneira distinta entre os lodos de sulfato de alumínio e de PACl. Para o primeiro, o fluxo de massa água evaporada foi elevado no inicio e diminuiu com o tempo, enquanto para o lodo de $\mathrm{PACl}$, ocorreu o inverso, menor fluxo de água evaporada no início, elevação do fluxo e novamente diminuição do fluxo até ocorrer absorção da umidade relativa do ar (dessorção). Este comportamento distinto pode estar relacionado 
com a formação de um filme contínuo de água na massa de lodo que evapora independente da interação sólido-líquido (David, 2002).

A formação ou não do filme contínuo de água pode ser função do teor de sólidos no início da secagem (parcela de água de ligação ou água livre não drenada) e também com as propriedades distintas dos lodos tais como, arranjo físico, propriedades reológicas (tamanho das partículas, viscosidade, tensões superficiais e cisalhantes).

Com relação as variáveis climáticas, a umidade e a insolação mostraram-se determinantes na velocidade de secagem das massas de lodos. A umidade relativa do ar acima de $70 \%$ dificultou a evolução da secagem, ainda que houvesse considerável ação do vento e temperatura do ar elevada em torno de $25^{\circ} \mathrm{C}$.

A precipitação como fator isolado não mostrou ser determinante na velocidade de secagem. Porém, quando da permanência de alta umidade relativa do ar, advindo com a chuva pode prejudicar decisivamente o desempenho do desaguamento.

A insolação apresentou relação diretamente proporcional a secagem e, além disso, afirmou-se como determinante das demais variáveis, tais como temperatura, evaporação e umidade relativa do ar. Haja vista, constituir-se na fonte de energia necessária para a transmissão de calor e radiação responsável por promover o fluxo de massa da umidade da massa de lodo para o ar, conforme reporta David (2002).

No estudo das micropropriedades e macropropriedades dos lodos, as análise realizadas por EDS indicaram aumento percentual de Al (possívelmente caulinita ou gibsita) e diminuição de carbono nas amostras de lodo desaguado em comparação as amostras de lodo bruto de $\mathrm{PACl}$. Já em relação aos lodos de sulfato de alumínio essa tendência não foi verificada. Tais indicações foram confirmadas com a realização da análise de difração de raios $\mathrm{X}$. 
O aumento percentual de argilominerais como a caulinita observado no lodo retido foi coerente com o ligeiro aumento de finos observados na determinação de distribuição de tamanho de partículas, uma vez que os argilo-minerais, principalmente caulinita e gibsita (presença de Alumínio) possuem tamanhos menores que $2 \mu \mathrm{m}$.

A predominância de SVT encontrado nas amostras de água drenada mostrou-se coerente com os resultados das análises de EDS e difração de raios X, em que ocorreu a indicação de diminuição percentual de "material orgânico". O aumento de COT nas águas drenadas pode ter correlação direta com a diminuição percentual de carbono nas amostras de lodo desaguado.

As análises de MEV/EDS realizadas nas amostras das mantas geotexteis (usada e não usada) mostraram a retenção de partículas muito pequenas, bem menores que a abertura de filtração da manta geotêxtil usada nos Leito de Drenagem. A forma como ocorre a retenção dessas partículas pode ter relação com a combinação de mecanismos de retenção de partículas, por autofiltração e pela formação de uma rede de $\operatorname{arcos}$ e mecanismos de colmatação, por causa química e física de predominância da forma "propriamente dita". 


\subsection{Proposição: Esclarecimento sobre o Desaguamento de lodos de ETAs por sistemas naturais (Leito de Drenagem)}

O desafio de compreender e sistematizar os fenômenos naturais envolvidos no desaguamento de lodo por sistemas naturais, particularmente o Leito de Drenagem, foi confrontado ao longo do desenvolvimento dessa pesquisa. Apesar das dificuldades encontradas pretende-se expor e elucidar os mecanismos envolvidos no desaguamento de lodos por leito de drenagem, baseados nos resultados, conceitos e definições estudados e discutidos na presente pesquisa.

A realização de trabalho, onde se requer um mínimo de energia é condição básica para qualquer tipo de atividade, seja humana, natural ou artificial. Os processos e operações industriais e do saneamento não fogem a esse princípio básico. Nesse contexto é que está o cerne e desafio do desaguamento dos lodos de ETAs, bem como de ETEs.

O desaguamento de lodos consiste, tão somente, na redução de volume mediante separação das frações sólida e líquida. Para tanto, é necessário o consumo de uma quantidade de energia que vai ser função das frações de água existentes no lodo, como citado ao longo do desenvolvimento da tese.

O uso de sistemas naturais de remoção de água, mais particularmente do uso de leito de drenagem caracteriza-se por usar eficientemente a energia fornecida pela força de gravidade, característica na Fase de Drenagem e uso de energia térmica proveniente do sol, e em menor intensidade energia eólica (ação do vento) na Fase de Secagem.

Na Fase de Drenagem busca-se a remoção da água livre (não ligada à fração sólida), enquanto na Fase de Secagem procura-se remover o residual de água livre e demais frações de água (água de ligação: água intersticial, viscinal e de hidratação).

$\mathrm{Na}$ Fase de Drenagem para retirar água livre dos lodos e suspensões requer suficiente energia para tornar irreversível o processo interno, tais como a fricção entre a massa de lodo 
e meio filtrante, no caso as mantas geotêxteis. A Lei de Darcy modificada é tipicamente usada para descrever esta força de friç̧ão. Segundo (Chu, Lee e Chang, 2005), a soma da força de ligação mais a força associada à perda por fricção indica teoricamente a parcela mínima de trabalho para desaguar uma suspensão ou lodo.

Assim, a remoção da água da massa de lodo requer: (1) que a força de ligação entre água adjacente e superfície sólida seja quebrada, sem remoção físíca da parcela de água; e (2) a água seja movida da posição original na suspensão para fora do sistema através da massa de lodo e meio filtrante. A energia necessária para separar a água adjacente da superfície sólida pode ser denominada como Eb, e a energia requerida para mover a água através da massa de lodo e meio filtrante é Ef. Portanto, a energia mínima requerida para desaguar um volume de lodo é dado por $(E b+E f)=$ Eefet. Se a energia consumida por um dispositivo de desaguamento Ev for maior que Eefet $=(E b+E f)$, o processo de desaguamento ocorrerá e se tornará irreversível.

Logo, a Fase de Drenagem terá sucesso, se somente se satisfizer a Equação (6.4).

$$
\mathrm{Ev}>\text { Eefet }=(\mathrm{Eb}+\mathrm{Ef})
$$

Na Fase de Drenagem, a energia Ev é fornecida pela força de gravidade, mas somente parte da energia fornecida é efetivamente usada durante o desaguamento. O resultado é a existência de uma eficiência média $\eta$, expressa na forma $(\eta \times \mathrm{Ev})$. Como Ev, é energia fornecida pela força de gravidade, $\eta$ pode ser entendido como característica da natureza do lodo (seja frações de água e propriedades reológicas) e do meio filtrante.

Portanto, como Ev (força de gravidade) praticamente constante, pode-se verificar os limites ou melhorar o desempenho do sistema conhecendo ou interferindo no fator $\eta$.

Na Fase de Secagem, Ev pode ser substituído por Et (energia térmica) fornecida pelo sol e Ev (energia eólica). A eficiência $\eta_{v}$, nesse caso relaciona-se com a natureza da massa de 
lodo (arranjo, distribuição de tamanho e estrutura da fração sólida) e com as variáveis climáticas.

Assim tem-se, na Fase de Desaguamento, a necessidade de atender a relação proposta pela Equação 6.5, para que ocorra o processo irreversível de desaguamento (perda de umidade do lodo por evaporação).

$$
(\eta+\eta v) . \text { Et }>\text { Eefet }=(E b+E f)
$$

Em sistemas naturais, como o leito de drenagem, a demanda por energia Ev e Et, é satisfeita sem ônus e com elevada disponibilidade. O que parece ser na teoria simples e vantajoso, revela na prática dificuldades que por sua vez deve ser transposta trabalhando em cima dos fatores $\eta e \eta_{v}$.

Após a explanação dos requisitos de energias envolvidos nos sistemas de desaguamento através de leito de drenagem, expõem-se os mecanismos envolvidos.

Na Fase de Drenagem, a transferência contínua de sólidos para o fundo dos leitos de drenagens decorre de duas ações distintas. A primeira é a sedimentação propriamente dita, por ação da gravidade. A segunda é o arraste dos sólidos pelo líquido que se desloca para baixo em movimento determinado pela drenagem da água livre do fundo através da manta geotextil e camada suporte de brita.

A taxa de transferência dos sólidos para baixo é denominada fluxo de sólidos, o qual é definido como a massa de sólidos que atravessa a unidade de área de uma seção horizontal na unidade de tempo. Assim, pode-se constatar que em amostras de lodos de ETAs submetidas ao desaguamento por Leito de Drenagem, o fluxo de sólidos total $G T$ expresso em $\left(\mathrm{kg} / \mathrm{m}^{2}\right) /$ unidade de tempo, é a soma do fluxo de sólidos por gravidade $G G$ com o fluxo de sólidos por arraste devido drenagem $G d$. Em que Gd é função das propriedades reológicas do lodo, tais como, teor de sólidos, distribuição de tamanho de partículas, tensão de cisalhamento, viscosidade entre outros. 
Sejam $X i[\mathrm{mg} / \mathrm{L}]$, a concentração de sólidos na seção considerada, $V i[\mathrm{~m} / \mathrm{h}]$ a velocidade de sedimentação do lodo com esta concentração $X i$ e $U$ [m/h] a velocidade descendente do líquido devido à drenagem de água livre. Os fluxos de sólidos por gravidade $G g i\left[\mathrm{~kg} / \mathrm{m}^{2} . \mathrm{dt}\right]$, por arraste devido drenagem $G d r i\left[\mathrm{~kg} / \mathrm{m}^{2} . \mathrm{dt}\right]$ e total $G T i\left[\mathrm{~kg} / \mathrm{m}^{2} . \mathrm{dt}\right]$ através da seção analisada são dadas, respectivamente, pelas equações 6.6, 6.7 e 6.8:

$$
\begin{aligned}
& \mathbf{G}_{G}=X i \cdot V i \cdot 10^{-3} \\
& \mathbf{G}_{d, r}=X i \cdot Q d \cdot 10^{-3} \\
& \mathbf{G}_{T}=(X i \cdot V i+X i \cdot Q d) \cdot 10^{-3}
\end{aligned}
$$

A ocorrência destes dois fatores, Gg e Gdr, aliados as propriedades reológicas do lodo, especialmente a distribuição de tamanho de partículas podem ser determinantes para as formas de retenção de partículas e definição do tipo de colmatação das mantas geotêxteis usadas, e conseqüentemente no desempenho e vida útil (operacional) do sistema.

\section{Explicando e compreendendo a Fase de Secagem}

Ao término da Fase de Drenagem, o lodo retido na manta mantém considerável teor de umidade que pode impossibilitar o manuseio e/ou adequada disposição.

Assim, a Fase de Secagem compreende a etapa destinada a remover a água não drenada contida na massa de lodo, para um meio gasoso insaturado, como no caso do ar, através da vaporização térmica, (David, 2002). A perda de água por evaporação ocorre a temperatura inferior àquela de ebulição da água, devido à relação de pressão de vapor da água no ar e no lodo.

Após a drenagem da água livre, a massa de lodo retida com determinado teor de sólidos (STd), é exposta a ação das variáveis climáticas sob temperatura (T), pressão de vapor da água no ar(Par) e umidade relativa do ar (Wr). O teor de sólidos na massa de lodo tende a evoluir até atingir o equilíbrio térmico com o meio e apresenta um valor STi, maior ou menor que STd. 
O equilíbrio térmico com o meio, bem como todo o processo de secagem é governado pela relação pressão de vapor na água contida no ar e pressão de vapor na água contido no sólido, (David, 2002). Quando a pressão de vapor da água no ar é maior que a pressão de vapor da água no material sólido, o material retira água do ar (diminuição de teor de sólidos) até equilibrar as pressões, sendo denominado de sorção. Por outro lado, se a pressão de vapor da água no ar (Par) é menor que a pressão de vapor da água no lodo (Pv), o ar retira água do lodo (aumento de teor de sólidos) até equilibrar as pressões, fenômeno denominado por desorção e de especial interesse para o desaguamento do lodo.

Para atingir a condição de equilíbrio de pressões de vapor é necessário que o meio de secagem, no caso o ar, tenha temperatura superior a do lodo para permitir um fluxo de calor e conseqüente vaporização da água contida na mesma. Para a continuidade do processo deve-se remover (ação do vento) a camada de umidade posicionada rente e superior a massa de lodo, conforme pode ser visualizado na Figura 6.60.

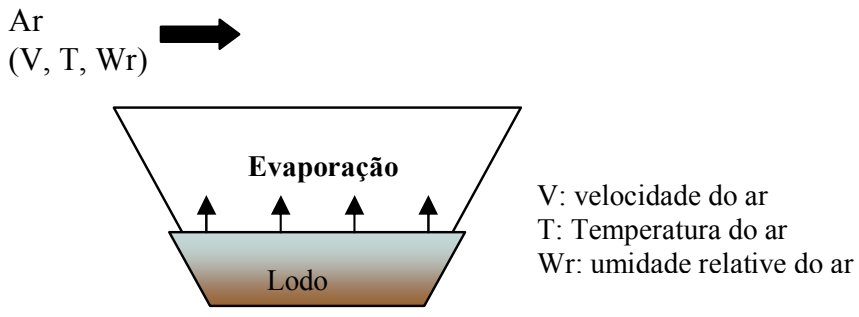

Figura 6.60 - Ilustração demonstrando a ação do vento na retirada de camada de umidade subjacente a superfície do lodo desaguado.

O calor transferido para o lodo forma um gradiente de temperatura da superfície para o interior do sólido, que causa a migração da umidade do interior para a superfície por mecanismos de escoamento capilar, difusão e diferenças de pressão interna. A continuidade da secagem faz com que a massa de umidade da superfície seja removida e substituída pela água que vem do interior do sólido. 
A intensidade da perda da água por evaporação é de especial interesse para o desempenho do leito de drenagem, pode ser entendida como a velocidade de secagem ou fluxo de massa de umidade que é retirada do lodo por unidade de área de exposição e por unidade de tempo, expresso por $\mathrm{kg}$ água/m $\mathrm{m}^{2} . \mathrm{T}$ (unidade de tempo). Pode ser representada pela Equação 6.9, a qual foi usada no capitulo 6.3.5 durante a avaliação da Fase de Secagem.

$$
\mathrm{F}_{\mathrm{mar}}=\mathrm{Md} / \mathrm{A} \times(\mathrm{dW} / \mathrm{dt})
$$

Em que:

$$
\begin{aligned}
& \mathrm{Md}=\text { massa de sólidos na base seca }(\mathrm{kg}) ; \\
& \mathrm{A}=\text { área de exposição (transferência de vapor de água) }\left(\mathrm{m}^{2}\right) ; \\
& \mathrm{dW}=\text { variação de umidade do lodo em base seca }(\%) ; \\
& \mathrm{dt}=\text { variação do tempo (dia). }
\end{aligned}
$$

Os fatores que influenciam a velocidade de secagem ou o fluxo de massa de água estão relacionados com: o mecanismo interno de fluxo de água através da massa de lodo; o coeficiente de transferência de massa e de calor; a área de exposição e a diferença de temperatura, umidade e pressão de vapor entre o ar e a massa de lodo.

O mecanismo interno de fluxo de água através da massa de lodo é função da natureza da massa de lodo, ou melhor, de suas propriedades reológicas (frações de água, tamanho de partículas, viscosidade e etc.) e constituição química. O coeficiente de transferência de massa e de calor e a área superficial de exposição são determinados pela configuração e concepção do sistema de desaguamento (leito de drenagem). Por ultímo, a necessária diferença de temperatura, umidade e pressão de vapor de água entre o ar e massa de lodo está relacionado com as condições climáticas.

Nesse contexto, a execução dessa tese deparou-se com a extensa gama de variáveis supracitadas e mostrou que os mecanismos de secagem do lodo da ETA por desaguamento através de leitos de drenagem são complexos e de difícil interpretação. 


\subsection{ANÁLISE CRÍTICA DOS RESULTADOS}

No desenvolvimento da pesquisa, bem como na discussão dos resultados foi seguido uma seqüência lógica, na qual as três hipóteses assumidas na concepção e desenvolvimento da tese foram, uma a uma, verificadas à medida que os objetivos específicos da tese foram cumpridos.

O Capítulo 4, relativo às referências bibliográficas reuniu diversos conceitos e definições da área do saneamento e das mais diferentes áreas do conhecimento, destacadamente da área de geotecnia e ciências dos materiais. A convergência dessas áreas no estudo de desaguamento de lodos de ETAs mostrou-se promissora e necessária, mas notadamente complexa pela deficiência de comunicação entre os atores envolvidos.

O Capítulo 6, seção 6.1, foram relatados os resultados dos estudos de conceituação e análise de determinas micropropriedades do lodo de ETA. O estudo de determinação das frações de água no lodo não logrou exito, contudo indicou a potencialidade do uso de energia térmica, na forma de congelamento e descongelamento, como alternativa de condicionamento ou espessamento de lodos de ETAs. Adicionalmente realizaram-se ensaios preliminares de desaguamento por leito de drenagem (Fase 01), fundamentais na sistematização dos ensaios da Fase 02.

A seção 6.2 (Fase 02) relatou os resultados dos ensaios e análises que subsidiaram ao cumprimento do objetivo principal da tese. Nesse contexto, pode-se dizer que:

Na Fase de Drenagem, o valor de TAS $\left(\mathrm{kg} / \mathrm{m}^{2}\right)$ e/ou ST (\%) mostrou-se determinante na definição da vazão de drenagem inicial de água livre. Esta observação assume importância no sentido de potencializar o uso de TAS como parâmetro de projeto.

A fração volumétrica de partículas, entendida nesse trabalho como a taxa de aplicação de sólidos (TAS) incidente sobre o leito de drenagem mostrou-se mais determinante no 
desempenho do leito de drenagem, que isoladamente as propriedades de concentração de sólidos ou de distribuição de tamanho de partículas.

O conhecimento mais aprofundado das características dos lodos, com destaque a distribuição do tamanho de partículas, sua relação com os mecanismos de sedimentação (sedimentação por gravidade e por arraste devido drenagem da água livre) e conseqüente propriedade de empacotamento do lodo durante a fase de drenagem podem concorrer para o desenvolvimento tecnológico do sistema de desaguamento. Além disso, pode contribuir para o potencial "enriquecimento" de Alumínio ou caulinita no lodo desaguado.

A análise da distribuição de tamanho de partículas mostrou-se extremamente importante para a compreensão dos mecanismos de desaguamento do lodo de ETAs. A tentativa de obter uma metodologia apropriada e de baixo custo, baseado nos procedimentos descritos por Balmat (1957), não teve êxito. Porém, não se tratava do objetivo desse trabalho. A técnica SEDIGRAPH usada nesta pesquisa mostrou-se mais adequada para as amostras de lodo desaguado (fração sólida). Para o lodo bruto constituído de partículas floculentas apresentou-se inadequada, posto que o preparo das amostras afeta a integridade das amostras.

Na Fase de Secagem, a velocidade de secagem mostrou ser influenciada pelo arranjo físico e estrutura cristalina da massa de lodo retido na manta geotêxtil, uma vez que estão relacionados com a capacidade de transporte por difusão do vapor de água através da massa de lodo e conseqüente evaporação (fluxo de umidade do lodo para o ar).

As variáveis climáticas, insolação (fonte de energia térmica), e umidade, responsável pelo equilíbrio da relação de pressão de vapor da água no lodo e pressão de vapor de água no ar, podem ser consideradas determinantes na velocidade de secagem (fluxo de umidade) e consequente desempenho do desaguamento por leito de drenagem. Contudo, faz-se necessário realizar estudos específicos que asseverem tal indicação. 
O material dreno/filtrante usado no leito de drenagem constituído pelas mantas geotêxteis promoveu a capacidade drenante da água livre das amostras de lodos e apresentou uma distribuição de tamanho de poros capaz de reter partículas floculentas ou sólidas. Dessa forma mostraram-se efetivos na remoção de sólidos, metais, turbidez e cor. Contudo, os resultados de variação de $\mathrm{pH}$ indicaram influência na capacidade drenante da manta, (qualidade da água drenada) possivelmente por interferir na colmatação por causas químicas.

Nesse sentido, a eficiência das mantas geotexteis durante a Fase de Drenagem pode ser explicada pela combinação de mecanismos de retenção de partículas (por autofiltração e formação de uma rede de arcos) e mecanismos de colmatação (por causa química e causa física).

O desenvolvimento desta pesquisa não permite afirmar que lodos originários de diferentes coagulantes como no caso, sulfato de alumínio e de cloreto de polialumínio (PACl), conferem, por si só, diferentes desempenhos no desaguamento por Leito de Drenagem. As características da água bruta e condições operacionais em que este lodo é produzido determinam à fração volumétrica de partículas (teor de sólidos, forma e distribuição de tamanho de partículas) relacionadas com as propriedades reológicas do lodo. As micro e macropropriedades concernentes a fração volumétrica estudadas na presente pesquisa mostraram-se determinantes no desempenho do desaguamento por leito de drenagem.

Diante da afirmativa supracitada, pode-se argumentar que os ensaios de desaguamento poderiam ser realizados considerando amostras com mesma concentração de sólidos. O autor afirma, mais uma vez, que a pesquisa teve caráter exploratório e tecnológico, e procurou representar as condições existentes nas ETAs. Tal atitude pode incorrer em limitações quanto à obtenção de conclusões definitivas entre os dois tipos de lodos estudados, porém permitiu ampliar a magnitude dos fenômenos observados no desaguamento de lodo por Leito de drenagem. 


\section{CONCLUSÕES}

Na presente pesquisa observaram-se avançados métodos e técnicas, especialmente em outros setores industriais e áreas de pesquisas, de caracterização e análise de comportamento dos materiais. A incorporação e interação com esses setores pode potencialmente contribuir para soluções mais eficientes no gerenciamento dos resíduos gerados na indústria da água.

Assim, a proposição da tese teve como cerne o caráter exploratório e baseado na apropriação tecnológica de diferentes áreas. Tal postura, por si só, encerra a busca de conclusões definitivas, ao contrário do que se teria em uma abordagem específica e dirigida, a respeito dos fenômenos envolvidos no desaguamento de lodos de ETAs por sistemas naturais, mais particularmente, com uso do Leito de Drenagem.

A contraditória complexidade de um processo natural, aparentemente simples, revelou-se no desenvolvimento desta pesquisa. A dificuldade de agregar e estabelecer comunicação entre distintas áreas do conhecimento, em certa medida pelo próprio autor, na direção de estudar as propriedades não tradicionais do lodo foi confrontado passo a passo ao desafio de compreender e sistematizar os fenômenos naturais envolvidos.

Durante a realização da tese tornou-se evidente a necessidade em aprofundar o conhecimento das características (micro e macropropriedades) e dos mecanismos mais fundamentais envolvidos no desaguamento de lodos de ETAs.

Assim, a partir da concepção e desenvolvimento desta pesquisa e conseqüentes resultados obtidos, são apresentadas as principais conclusões desta tese.

- Os resultados comprovaram o desempenho do Leito de Drenagem para redução de volume, da ordem de $90 \%$ e 80 \% para os lodos de Sulfato de Alumínio e de PACl, e teor de sólidos final de 30 a $90 \%$, sem consumo de energia ou adição de produtos químicos. 
- Na Fase de Drenagem, independente do tipo e volume de lodo aplicado, a vazão de drenagem foi maior quanto menor o valor da taxa de aplicação de sólidos - TAS $\left(\mathrm{kg} / \mathrm{m}^{2}\right)$ (fração volumétrica de partículas). Este aspecto torna-se importante, pois pode constituir-se de um parâmetro de projeto.

- O material dreno/filtrante, constituído pelas mantas geotêxteis, usado no leito de drenagem promoveu a capacidade drenante da água livre das amostras de lodos e apresentou uma distribuição de tamanho de poros, capaz de reter partículas floculentas ou sólidas. A eficácia das mantas geotexteis durante a Fase de Drenagem pode ser explicada pela combinação de mecanismos de retenção de partículas (por autofiltração e formação de uma rede de arcos) e mecanismos de colmatação (por causa química e causa física).

- A qualidade da água livre drenada teve relação direta com a concentração de sólidos inicial dos lodos de sulfato de alumínio e de PACl usados nos ensaios de desaguamento por Leito de Drenagem.

- As características da água livre drenada indicaram efetiva remoção de sólidos e metais nas amostras de lodos de sulfato de alumínio e de PACl.

- O teor de sólidos inicial da Fase de Secagem e possívelmente as propriedades reológicas da massa de lodo desaguado foram determinantes para diferentes mecanismos de secagem e influência na velocidade de secagem. Adicionalmente, a avaliação das estruturas cristalinas dos lodos brutos e desaguados permitiu inferir na compreensão da influencia da distribuição de tamanho de partículas nas frações de água.

- A avaliação qualitativa das frações sólidas dos lodos de sulfato de alumínio e de PACl baseado nas análises de MEV/EDS e difração de raios X confirmaram a composição predominante de argilominerais principalmente a caulinita, gibsita e quartzo. No lodo de $\mathrm{PAC} \ell$ teve ocorrência de hematita.

- O uso do conceito Fluxo de massa de umidade mostrou-se uma importante ferramenta para avaliação da Fase de secagem no desaguamento dos lodos de ETAs por Leito de Drenagem.

- As variáveis climáticas, umidade e insolação mostraram-se determinantes na secagem do lodo. A evaporação apresentou potencialidade para monitoramente e previsão da velocidade de secagem, principalmente de lodos com alto teor de sólidos. 
- No estudo das frações de água dos lodos, observou-se que o uso de energia térmica, mediante congelamento e descongelamento do lodo de ETAs mostrou-se efetivo para desaguamento de residuos de ETAs, porquanto eleva a velocidade de sedimentação e promove separação das frações sólidas e líquidas dos residuos de ETAs.

- O estudo das micro e macropropriedades do lodo mostram-se decisivos para balisarem pesquisas de desenvolvimento dos sistemas de desaguamento e de reúso dos lodos de ETAs.

Por fim, pode-se afirmar que a busca de respostas e esclarecimentos, diante da ampliação dos fenômenos observados na presente pesquisa, terá êxito mediante a incorporação de conhecimentos advindos das mais diversas áreas do conhecimento. 


\section{SUGESTÕES}

Tendo em vista o que foi apresentado e discutido nesta tese sugere-se:

- Avaliar a realização de caracterização tradicional e "não tradicional" de lodo bruto e de lodo desaguado provenientes de sulfato de aluminio e de $\mathrm{PAC} \ell$, com vistas a potencial de reutilização.

- Estudar valores de TAS (taxa de aplicação de sólidos) mais adequados para o melhor desempenho do desaguamento por Leito de Drenagem. Entende-se como melhor desempenho, aquele em que a velocidade de drenagem é maior e qualidade do drenado atenda os requisitos minimos para determinado destino.

- Estudar a necessidade de desenvolver procedimentos específicos de preparo de amostras e de técnicas de análises relativos a caracterização quantitativa e qualitativa da fração sólida dos lodos de ETAs mediante uso de Microscopia eletrônica de varredura (MEV), espectroscopia por dispersão de energia de Raios X (EDS) e Difração de Raios-X.

- Estudar técnica mais adequada para determinação de distribuiçao de tamanho de partículas para as amostras de lodo de ETAs, destacadamente das partículas floculentas envolvidas no processo de sedimentação/drenagem durante a Fase de Drenagem no desaguamento por Leito de Drenagem.

- Desenvolver estudos, baseado nos procedimentos descritos por Balmat (1957) e outros autores, no sentido de obter uma metodologia apropriada e de baixo custo, para determinação da distribuição de tamanho de partículas em lodos de ETAs, mais adequada a realidade das companhias de saneamento no Brasil.

- Desenvolver estudos específicos sobre as propriedades reológicas do lodo, destacamente relacionado com a capacidade empacotamento.

- Estudar aproveitamento de concentradores de energia solar com uso de espelhos ou embalagens de "tetrapark" como forma de intensificar o fornecimento de energia térmica durante a secagem do lodo atraves do leito de drenagem. 


\section{REFERÊNCIAS BIBLIOGRÁFICAS}

ACHON, C.L.; CORDEIRO, J.S. Gerenciamento de lodo de ETAs - Remoção de água livre através de Leitos de Secagem e Lagoas. Anais do $22^{\circ}$ Congresso Brasileiro de Engenharia Sanitária e Ambiental - Joinville, 2003. cd. I-047.

ACHON, C. L.; CORDEIRO, J. S. Gerenciamento de lodo de ETAs remoção de água livre através de leitos de secagem e lagoas. In: $10^{\circ}$ CONGRESSO DE INICIAÇÃO CIENTÍFICA, Florianópolis, 2002.

ALMEIDA, H. Comunicação sobre ensaios realizados visando a utilização de lodo decantado como auxiliar de tratamento. Anais do $6^{\circ}$ Congresso Brasileiro de Engenharia Sanitária Salvador, 1975.

AMERICAN PUBLIC HEALTH ASSOCIATION; AMERICAN WATER WORKS ASSOCIATION - WATER ENVIRONMENT FEDERATION. Standard methods for the examination of water and wastewater. 21. ed. Washington DC, USA, 2005.

AMERICAN WATER WORKS ASSOCIATION; AMERICAN SOCIETY OF CIVIL ENGINEERS; U. S. ENVIROMENTAL PROTECTION AGENCY. Management of Water Treatment Plant Residuals. American Society of Civil Engineers, New York, 1996.

ANDRADE, P. S. Avaliação do impacto ambiental da utilização de resíduos de estações de tratamento de água em indústrias de cerâmica vermelha: Estudo de caso. Dissertação (Mestrado) - Universidade Estadual de Campinas/UNICAMP, Faculdade de Engenharia Civil. Campinas, 2005.

ARMITHRAJAH, A.; MILLS, K.M. Rapid-Mix Design for Mechanisms of Alum coagulation. Journal AWWA, Vol. 74, pp.210-216, 1982.

ASSOCIAÇÃO BRASILEIRA DE NORMAS TÉCNICAS - ABNT. NBR 10.004 - Resíduos sólidos - Classificação, São Paulo, 2004. 
BALMAT, J. L. Biochemical oxidation of various particulate fractions of sewage. Sew. Ind. Waste, v. 29, n. 7, pp. 757-761, 1957.

BARBOSA, R.M. Avaliação do impacto de efluentes (lodos) de ETAs à biota aquática através de testes de toxicidade. Tese (Doutorado). Escola de Engenharia de São Carlos, 199p, São Carlos, 2000.

BARRoso, M. M. Problemática dos metais e sólidos no tratamento de água (estação convencional de ciclo completo). Dissertação (Mestrado) - Escola de Engenharia de São Carlos, 140p, São Carlos, 2002.

BRAGA, W. M.; GONCALVES, R. F. Influência do comportamento reológico dos filtrados sobre a resistência específica à filtração de lodos de ETE's condicionados com polieletrólitos. In: XI Simpósio Luso-Brasileiro de Engenharia Sanitária e Ambiental, 2004, Natal. Anais do XI SILUBESA, 2004.

CARVALHO, E. H. Disposição de resíduos de estações de tratamento de água em estações de tratamento de esgoto com decantação primária. Tese (Doutorado). Escola de Engenharia de São Carlos, 171p, São Carlos, 2000.

CHAO, I. R. S. Remoção de fósforo de efluentes de estações de tratamento biológico de esgotos utilizando lodo de estação de tratamento de água. Dissertação (Mestrado). Escola Politécnica da Universidade de São Paulo, 160 p, São Paulo, 2006.

CORDEIRO.J.S. Disposição, tratabilidade e reuso de estações de tratamento de águas. Dissertação (Mestrado), Escola de Engenharia de São Carlos, 155p, 1981.

. O problema dos lodos gerados em decantadores de estações de tratamento de águas, EESC/USP - SHS, tese de doutorado, Escola de Engenharia de São Carlos, 342p, 1993.

. Processamento de Lodos de Estações de tratamento de água (ETA). In:

FINEP, CNPq,CEF. (Org.). Resíduos Sólidos do Saneamento: Processamento, Reciclagem e Disposição Final. Rio de Janeiro: RIMA-ABES, v. 1, pp. 119-142, 2001. 
CORNWELL, D.A.; BURMASTER, J.W.; FRANCIS, J.L.; FRIEDLINE Jr., J.C.; HOUCK, C.; KING, P.H.; KNOCKE, W.R.; NOVAK, J.T.; ROLAN, A.T.; SAN GIACOMO, R. Committee Report: Research Needs for Alum Sludge Discharge. Journal AWWA, v.79, p.99$105,1987$.

CORREA, C.A. Microscopia eletrônica de transmissão. In: CANEVAROLO JR, S.V. (Ed.) Técnicas de caracterização de polímeros. São Paulo: Artliber, pp.177-199, 2003.

CHU, C.P.; LEE, D.J.; CHANG, C.Y. Energy demand in sludge dewatering. Water Research v. 39, pp. 1858-1868, 2005.

DAVID, A. C. Secagem térmica de lodos de esgoto: determinação da umidade de equilíbrio. São Paulo, Dissertação (Mestrado). Escola Politécnica da Universidade de São Paulo, 151 p, São Paulo, 2002.

DENTEL, S. K. Evaluation and role of rheological properties in sludge management. Water Science and Technology, v. 36, n. 11, p. 1-8, 1997.

DHARMAPPA, H. B.; HASIA, A.; HAGARE, P. Water treatment plant residuals management. Water Science and Technology, vol 35 n. 8, pp 45-56, 1997.

DIAS, L. M.; BATOLIONE, G.; MORAIS, F. U.; FERNANDES SOBRINHO, J.; RIBEIRO, M. C.; LISBOA, M. S. Alternativa de Destinação Final do Lodo de Estação de Tratamento de Água - Fabricação de Blocos Cerâmicos. In: XXVIII Congreso Interamericano de Ingenieria Sanitaria y Ambiental, 2002, Cancun. XXVIII Congreso. México: AIDIS, 2002.

DI BERNARDO, L.; DANTAS, A. D. B. Métodos e Técnicas de Tratamento de Água. 2. ed. São Carlos: Rima Editora, v. 2, 2005.

DULIN, B.E.; KNOCKE, W.R. The impact of incorporated organic matter on the dewatering characteristics of aluminum hydroxide sludges. Journal $A W W A$, v. 81, n. 5, pp.74-79, May, 1989. 
FEITZ, A. J.; GUAN, J.; WAITE, T. D. Size and structure effects on centrifugal dewatering of digested sewage sludge. Water Science and Technology. v. 44, n. 2, pp. 427-435, 2001.

FERNANDES, A. N. Balanço de massa e produção de lodo da estação de tratamento de água Alto da Boa Vista - SABESP. São Paulo. Dissertação (Mestrado) - Escola Politécnica da Universidade de São Paulo. 203 p, São Paulo, 2002.

FONTANA, A.O. Sistema de Leito de Drenagem e Sedimentador Como Solução Para Redução de Volume de Lodo de Decantadores e Reuso de Água de Lavagem de Filtros Estudo de Caso - ETA Cardoso. Dissertação (Mestrado) - Universidade Federal de São Carlos/UFSCAR. São Carlos, 2004.

FREITAS, R. A. S. Comportamento de geotêxteis como filtro em resíduos - Fosfogesso e Lama vermelha. Dissertação (Mestrado). COPPE/Universidade Federal do Rio de Janeiro. 122p, Rio de Janeiro, 2003.

GATTES, C. D., MCDERMOTT, R. P. Characterization and conditioning of water treatment plant sludge. Journal AWWA. Denver, v. 60, n. 3, pp. 33144, mar, 1968.

GONÇALVES, M.C. Microscopia eletrônica de varredura. In: CANEVAROLO JR, S.V. (Ed.) Técnicas de caracterização de polímeros. São Paulo: Artliber, pp.165-175, 2003.

GOMES, R. M. O. Modelo de implantação de um laboratório de geossintéticos. Dissertação de mestrado - Instituto Tecnológico da Aeronáutica. Divisão de Engenharia de Infra-estrutura Aeronáutica - ITA/IEI, pp. 126, São José dos Campos, 2002.

GRANDIN, S. R. Desidratação de lodos produzidos nas estações de tratamento de água. Dissertação (Mestrado). Escola Politécnica-USP. São Paulo, 1992. 
HOEHN, R.C.; DIXON, K.L.; MALONE, J.K.; NOVAK, J.T.; RANDALL, C.W. (1984).

Biologically induced variations in the nature and removability of THM precursors by alum treatment. Journal AWWA, pp. 134-141, 1984.

IBGE - INSTITUTO BRASILEIRO DE GEOGRAFIA E ESTATÍSTICA, DEPARTAMENTO DE POPULAÇÃO E INDICADORES SOCIAIS (2000). Pesquisa Nacional de Saneamento Básico. Disponível em

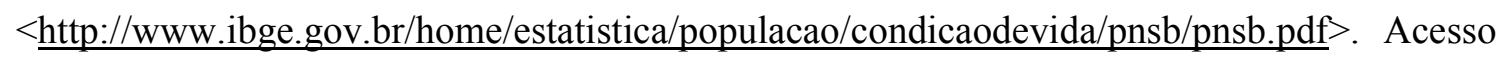
em nov, 2004.

JOHN N. W. M. Geotextiles. New York. Chapman and Hall, 1987.

JORDÃO, E. P.; PESSÔA, C. A. Tratamento de Esgotos Domésticos. 4a Edição (2005). Rio de Janeiro: ABES, 932p, 1995.

LAWLER, D. F. Particle size distribution in treatment processes: theory and practice. Water Science and Technology. v. 36, n. 04, pp. 15-23, 1997.

MARTEL, C. J.; AFFLECK, R.; YUSHAK, M. Operational parameters for mechanical freezing of alum sludge. Water Research, v. 32, n.9, pp. 2646-2654, 1998.

MIKI, M. K. Utilização de polímeros para condicionamento de lodo de ETE para desidratação em filtro prensa de placas. Dissertação (Mestrado). Escola politécnica da Universidade de São Paulo. Departamento de Engenharia Hidráulica. São Paulo, 1998.

MORAES, E M.; PAIM, A P S.; ZAIAT, M.; REALI, M. A. P. Determinação da DQO em Águas com baixas Concentrações de Matéria Orgânica. Engenharia Sanitária e Ambiental, v. 8, n. 3, pp. 182-186, 2003.

MORITA, D. M.; SAMPAIO, A. O.; MIKI, M. K.; DAVID, A. C. Incorporação de lodos de estações de tratamento de água em blocos cerâmicos. Revista SANEAS, v. 14, pp. 7-12. São Paulo, 2002. 
OLIVEIRA, E. M. S.; MACHADO, S. Q.; HOLANDA, J.N.F. Caracterização de resíduo (lodo) proveniente de estação de tratamento de águas visando sua utilização em cerâmica vermelha. Cerâmica, v. 50, pp. 324-330. Rio de Janeiro, 2004.

ORMECI, B.; VESILIND, P. A. Effect of dissolved organic material and cations on freezethaw conditioning of activated and alum sludges. Water. Research. v. 35, n. 18, pp. 4299 4306, 2001.

ORTEGA, F. S.; PANDOLFELli, V. C.; RODRIGUES, J. A.; SOUZA, D. P. F. ARTIGO REVISÃO: Aspectos da Reologia e da Estabilidade de Suspensões Cerâmicas. Parte I: Fundamentos. Cerâmica, v. 43, n. 279, pp. 5-10, 1997.

PARKER, P. J.; COLLINS, A. G. Ultra-rapid freezing of water treatment residuals. Water Research, v. 33, n. 10, pp. 2239 $\pm 2246,1999$.

REALI, M.A.P. Principais características quantitativas e qualitativas do lodo de ETAs. In: REALI, M.A.P (Coord.). Noções gerais de tratamento e disposição final de lodos de estações de tratamento de água. Projeto PROSAB, Rio de Janeiro: ABES, p.250, 1999.

SABESP - Companhia de Saneamento do Estado de São Paulo. Recuperação das águas de lavagens, tratamento e disposição de resíduos sólidos das ETAs da RMSP. Revista DAE, v.47, n. 150, pp.216-219, dez, 1987.

SAMPAIO, R. M. B.; VIDAL, D.; URASHIMA, D. C. Simulação do processo de carreamento e retenção de partículas em filtro têxteis. In: VI ENCITA 6rd Encontro de Iniciação Cientifíca e Pós-Graduação do ITA, 2000, São José Campos. VI ENCITA 6rd Encontro de Iniciação Cientifíca e Pós-Graduação do ITA, 2000.

SANTOS, I. S. S., RAMIRES, M. V. V., KAZMIERCZAK, C. S., KERN, A. P., CAMARGO, S. A. Reciclagem do Resíduo (lodo) da Estação de Tratamento de Água do Município de São Leopoldo - RS In: $45^{\circ}$ Congresso Brasileiro de Cerâmica $6^{\circ}$ do Mercosul, 2001, Florianopólis. São Paulo: Associação Brasileira de Cerâmica, 2001. 
SANTOS, H. R.; PRADO, G. S.; VIDAL, C. M. S.; MORUZZI, R. B.; CAMPOS, J. R. Aplicabilidade das Técnicas de Determinação de Tamanho de Partículas em Sistemas de Tratamento de Água e Esgoto Sanitário. Revista Engenharia Sanitária e Ambiental. v.9, n.4, pp.291-300. Out/Dez, 2004.

SANTOS, B. F.; GIORDANO, A (2005). Proposta de um método de cálculo do tempo de sedimentação no tratamento de esgotos por lodos ativados em bateladas. Revista Engenharia Sanitária e Ambiental. 185 Vol.10 - No 3 - Jul-Set 2005, pp. 185-193, 2005.

SILVA JÚNIOR, A. P. Tratabilidade do lodo de decantadores convencional e de alta taxa. Dissertação (mestrado) - Universidade Estadual de Campinas/UNICAMP, Faculdade de Engenharia Civil. Campinas, 2003.

SLATTER, PT. Sludge pipeline design. Water Science and Technology. v. 44, n. 10, pp. 9-18, 2001.

The rheological characterisation of sludges. Water Science and Technology. v. 36, n. 11, pp. 9-18, 1997.

SMOLLEN, M.; KAFAAR, A. Electroosmotically enhanced sludge dewatering: Pilot-Plant Study. Water Science Technology. v. 30, n.8, pp. 159-168, 1994.

SOUZA FILHO, A.G.; Di BERNARDO, L. Caracterização e clarificação da água de lavagem dos filtros de uma ETA que utiliza cloreto férrico como coagulante primário. (CD ROM) In: $20^{\circ}$ Congresso Brasileiro de Engenharia Sanitária e Ambiental, 1999. Rio de Janeiro, Anais. Rio de Janeiro, ABES. II-058, 1999.

SOUZA, F. G. C. Ocorrência de sólidos e metais na água tratada e nos resíduos gerados em ETA convencional de ciclo completo com descargas diárias. Dissertação (Mestrado) - Escola de Engenharia de São Carlos, Universidade de São Paulo, São Carlos, 2004. 
URASHIMA, D. C.; VIDAL, D. Dimensionamento por Teoria Probabilística de Filtros em Geotêxteis não-tecido. In: II Simpósio Brasileiro sobre Aplicação de Geossintéticos, 1995, São Paulo. II Simpósio Brasileiro sobre Aplicação de Geossintéticos, pp. 267-276, 1995.

VAN BENSCHOTEN, J.E.; EDZWALD, J.K. Chemical aspects of coagulation using aluminum salts - I. Hydrolytic reactions of alum and polyaluminum chloride. Water Research. v. 24, n. 12, pp. 1519-1526, 1990.

VAN VLACK, L.H. Princípios de ciência e tecnologia dos materiais. 4. ed. Rio de Janeiro: Campus, 1984.

VESILIND, P.A.; HSU, C.C. Limits of sludge dewaterability. Water Science Technology. v. 36, n.11, pp. 87-91, 1997. 
Anexos 
Tabela A1 - Descrição das variáveis climatológicas fornecidas pela Estação Climatológica Clássica (CP São Carlos, n. 83726) localizada na UFSCar.

\begin{tabular}{|c|c|}
\hline Variáveis Climatológicas & Descrição \\
\hline TEMPERATURA DO AR & $\begin{array}{l}\text { valor do termômetro seco depois de feita a } \\
\text { correção instrumental. }\end{array}$ \\
\hline TEMPERATURA DO BULBO ÚMIDO & $\begin{array}{l}\text { leitura do termômetro úmido depois de feita a } \\
\text { correção instrumental. }\end{array}$ \\
\hline TEMPERATURA MÁXIMA & $\begin{array}{l}\text { leitura do termômetro de máxima depois de feita } \\
\text { a correção instrumental. }\end{array}$ \\
\hline TEMPERATURA MÍNIMA & $\begin{array}{l}\text { leitura do termômetro de mínima depois de feita a } \\
\text { correção instrumental. }\end{array}$ \\
\hline UMIDADE RELATIVA & $\begin{array}{l}\text { valor extraído da tabela psicométrica depois de } \\
\text { feita a correção de altitude.. }\end{array}$ \\
\hline VENTO (DIREÇÃO DE VELOCIDADE) & valor encontrado no momento da observação. \\
\hline PRECIPITAÇÃO TOTAL & soma das precipitações das $06,12,18$ e 24 horas. \\
\hline EVAPORAÇÃO & $\begin{array}{l}\text { registro do valor correspondente à água } \\
\text { evaporada. }\end{array}$ \\
\hline INSOLAÇÃO DIÁRIA & $\begin{array}{l}\text { registro do valor da insolação (hora e décimos) } \\
\text { conforme a tira heliográfica }\end{array}$ \\
\hline NEBULOSIDADE & quantidade de nuvens calculada em décimos. \\
\hline VISIBILIDADE & $\begin{array}{l}\text { lançamento do número correspondente à distância } \\
\text { (conforme quadro de visibilidade do posto). }\end{array}$ \\
\hline PRECIPITAÇÃO & $\begin{array}{l}\text { registro da quantidade de água recolhida na hora } \\
\text { da observação. }\end{array}$ \\
\hline GÊNERO DE NUVENS & $\begin{array}{l}\text { as estações possuidoras do atlas de nuvens } \\
\text { preencherão as colunas lançando somente os } \\
\text { gêneros das nuvens observadas. }\end{array}$ \\
\hline INSOLAÇÃO HORÁRIA & $\begin{array}{l}\text { valor correspondente ao registro horário da tira } \\
\text { heliográfica (horas ou décimos). }\end{array}$ \\
\hline
\end{tabular}

Fonte - Mapa de observações metereológicas do Instituto Nacional de Metereologia. 
Tabela A2 - Cálculo dos valores de Taxa de Aplicação de Sólidos TAS $\left(\mathrm{kg} / \mathrm{m}^{2}\right)$.

\begin{tabular}{|c|c|c|c|c|c|}
\hline Amostras & $\begin{array}{c}\text { Vol.(L) } \\
{[\text { I] }}\end{array}$ & $\begin{array}{c}\text { ST (\%) } \\
\text { [II] }\end{array}$ & 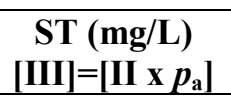 & $\begin{array}{c}\operatorname{massa}(\mathrm{mg}) \\
{[\mathrm{IV}]=[\mathrm{I}] \times[\mathrm{III}]}\end{array}$ & $\begin{array}{l}\text { TAS (kg/m2) } \\
{[\mathrm{V}]=[\mathrm{IV}] / \mathrm{A}_{\mathrm{i}}}\end{array}$ \\
\hline \multicolumn{6}{|l|}{$\begin{array}{c}\text { Ensaio 1 } \\
\text { (Leito de Drenagem I) }\end{array}$} \\
\hline Lodo de $\mathrm{Al}_{2} \mathrm{SO}_{4}$ & 25 & 2,6 & 23572,1 & 589301,9 & 3,43 \\
\hline Lodo de PACl & 25 & 1,4 & 12785,4 & 319634,7 & 1,86 \\
\hline \multicolumn{6}{|l|}{$\begin{array}{c}\text { Ensaio 2 } \\
\text { (Leito de Drenagem I) }\end{array}$} \\
\hline Lodo de PACl & 20 & 0,22 & 2009,1 & 40182,6 & $\mathbf{0 , 2 3}$ \\
\hline \multicolumn{6}{|l|}{$\begin{array}{c}\text { Ensaio } 3 \\
\text { (Leito de Drenagem II) }\end{array}$} \\
\hline Lodo de $\mathrm{Al}_{2} \mathrm{SO}_{4}$ & 8 & 7,6 & 68902,89 & 551223,93 & 7,35 \\
\hline Lodo de PACl & 8 & 0,04 & 365,29 & 2922,4 & 0,04 \\
\hline \multicolumn{6}{|l|}{$\begin{array}{c}\text { Ensaio } 4 \\
\text { (Leito de Drenagem I) }\end{array}$} \\
\hline Lodo de $\mathrm{Al}_{2} \mathrm{SO}_{4}$ & 55 & 0,76 & 6890,29 & 378966,5 & 2,2 \\
\hline Lodo de PACl & 55 & 0,26 & 2374,43 & 130593,6 & 0,76 \\
\hline \multicolumn{6}{|l|}{$\begin{array}{c}\text { Ensaio 5A } \\
\text { (Leito de Drenagem II) }\end{array}$} \\
\hline Lodo de $\mathrm{Al}_{2} \mathrm{SO}_{4}$ & 8 & 2,7 & 24478,7 & 195829,6 & 2,61 \\
\hline Lodo de PACl & 8 & 0,28 & 2557,1 & 20456,6 & $\mathbf{0 , 2 7}$ \\
\hline \multicolumn{6}{|l|}{$\begin{array}{c}\text { Ensaio 5B } \\
\text { (Leito de Drenagem II) }\end{array}$} \\
\hline Lodo de $\mathrm{Al}_{2} \mathrm{SO}_{4}$ & 8 & 4,2 & 38077,97 & 304623,75 & 4,06 \\
\hline Lodo de PACl & 8 & 0,21 & 1917,81 & 15342,466 & $\mathbf{0 , 2 0}$ \\
\hline $\begin{array}{l}\text { A1 - Leito de Drenagem } \\
\text { A2 - Leito de Drenagem } \\
p_{a}=1,103 \text { (valor adotad } \\
p_{p a c}=1,095 \text { (valor adota }\end{array}$ & $\begin{array}{l}\text { Área d } \\
\text { I - Área c } \\
\text { de peso }\end{array}$ & $\begin{array}{l}\text { fundo }(\mathrm{m} \\
\text { e fundo (n } \\
\text { specífico }\end{array}$ & $\begin{array}{r}(0,40 \times 0,43)= \\
-(0,2 \times 0,30)= \\
\text { odo de } \mathrm{Al}_{2} \mathrm{SO}_{4}\end{array}$ & $\begin{array}{l}172 \\
75\end{array}$ & \\
\hline
\end{tabular}


Tabela A3 - Caracterização das amostras obtidas no Ensaio 1 (02/07/2004) e Ensaio 2 (05/07/2004) de fracionamento com determinação da serie de sólidos e volume acumulado.

\begin{tabular}{|c|c|c|c|c|c|c|}
\hline \multicolumn{7}{|l|}{ Ensaio 1} \\
\hline & $\begin{array}{c}\text { Volume } \\
\text { amostragem } \\
(\mathrm{mL})\end{array}$ & $\begin{array}{c}\text { Volume } \\
\text { acumulado } \\
(\mathrm{mL})\end{array}$ & ST (mg/L) & STF (mg/L) & STV (mg/L) & Massa (g) \\
\hline Lodo bruto & 25 & 184,0 & 84860,0 & 5672,8 & 79187,2 & 15,61 \\
\hline$>74(\mu \mathrm{m})$ & 52 & 159,0 & 34248,1 & 2462,9 & 31785,2 & 5,45 \\
\hline $53(\mu \mathrm{m})$ & 55 & 107,0 & 62120,0 & 4419,1 & 57700,9 & 6,65 \\
\hline $38(\mu \mathrm{m})$ & 52 & 52,0 & 68275,0 & 4498,7 & 63776,3 & 3,55 \\
\hline \multicolumn{7}{|l|}{ Ensaio 2} \\
\hline & $\begin{array}{c}\text { Volume } \\
\text { amostragem } \\
(\mathrm{mL}) \\
\end{array}$ & $\begin{array}{c}\text { Volume } \\
\text { acumulado } \\
(\mathrm{mL})\end{array}$ & ST (mg/L) & STF $(\mathrm{mg} / \mathrm{L})$ & STV (mg/L) & Massa (g) \\
\hline Lodo bruto & 50 & 550,0 & $14.368,0$ & $8.066,0$ & $6.302,0$ & 7,90 \\
\hline$>74(\mu \mathrm{m})$ & 50 & 500,0 & $3.358,0$ & $2.420,0$ & 938,0 & 1,68 \\
\hline $53(\mu \mathrm{m})$ & 50 & 450,0 & $6.350,0$ & $4.660,0$ & $1.690,0$ & 2,86 \\
\hline $38(\mu \mathrm{m})$ & 80 & 400,0 & $5.743,7$ & $4.217,5$ & $1.526,3$ & 2,30 \\
\hline $20(\mu \mathrm{m})$ & 80 & 320,0 & $1.600,0$ & 89,1 & $1.510,9$ & $\mathbf{0 , 5 1}$ \\
\hline $8(\mu \mathrm{m})$ & 80 & 240,0 & $1.351,2$ & 51,5 & $1.299,7$ & $\mathbf{0 , 3 2}$ \\
\hline $5(\mu \mathrm{m})$ & 80 & 160,0 & $1.022,5$ & 55,0 & 967,5 & 0,16 \\
\hline $1,2(\mu \mathrm{m})$ & 80 & 80,0 & 987,5 & 65,0 & 922,5 & $\mathbf{0 , 0 8}$ \\
\hline
\end{tabular}

Tabela A4 - Resultado de ensaio de sólidos sedimentáveis (mL/L) das amostras de lodo bruto e descongelado (após congelamento) dos Ensaios 1 e 2.

\begin{tabular}{c|c|c|c|c}
\hline \multirow{2}{*}{$\begin{array}{c}\text { Tempo } \\
\text { (horas })\end{array}$} & \multicolumn{2}{|c|}{ Ensaio $1\left(\mathrm{ST}_{\mathrm{o}}=1,6 \%\right)$} & \multicolumn{2}{c}{ Ensaio 2 $\left(\mathrm{ST}_{\mathrm{o}}=1,6 \%\right)$} \\
\cline { 2 - 5 }$(\mathrm{mL} / \mathrm{L})$ & $\begin{array}{c}\text { Lodo bruto } \\
(\mathrm{mL} / \mathrm{L})\end{array}$ & $\begin{array}{c}\text { Lodo bruto } \\
(\mathrm{mL} / \mathrm{L})\end{array}$ & $\begin{array}{c}\text { Lodo descongelado } \\
(\mathrm{mL} / \mathrm{L})\end{array}$ \\
\hline 1 & 998 & 660 & 980 & 660 \\
\hline 2 & 998 & 360 & 960 & 320 \\
\hline 24 & 996 & 300 & 950 & 290 \\
\hline 48 & 996 & 290 & 950 & 270 \\
\hline
\end{tabular}

Tabela A5 - Resultados dos valores dos ensaios em coluna de sedimentação (mL) das amostras de lodos de sulfato de alumínio e de PACl.

\begin{tabular}{c|c|c}
\hline $\begin{array}{c}\text { Ensaio 1 } \\
\text { Tempo } \\
(\mathbf{m i n})\end{array}$ & $\begin{array}{c}\text { Lodo de Sulfato de Alumínio } \\
(\mathbf{S T}=\mathbf{2 , 6 \%})\end{array}$ & $\begin{array}{c}\text { Lodo de PACl } \\
(\mathbf{S T}=\mathbf{1 , 4 \%})\end{array}$ \\
\hline 10 & 960 & 800 \\
\hline 20 & 910 & 660 \\
\hline 30 & 890 & 540 \\
\hline 60 & 680 & 470 \\
\hline 900 & 410 & 450 \\
\hline 1440 & 400 & 440 \\
\hline 2880 & 390 & 440 \\
\hline
\end{tabular}




\begin{tabular}{|c|c|c|}
\hline Ensaio 2 & & \\
\hline $\begin{array}{l}\text { Tempo } \\
\text { (min) }\end{array}$ & "Não teve amostra" & $\begin{array}{c}\text { Lodo de PACl } \\
(\mathrm{ST}=0,22 \%)\end{array}$ \\
\hline 0 & - & 1000 \\
\hline 5 & - & 880 \\
\hline 10 & - & 760 \\
\hline 15 & - & 640 \\
\hline 20 & - & 525 \\
\hline 25 & - & 450 \\
\hline 30 & - & 400 \\
\hline 35 & - & 360 \\
\hline 40 & - & 320 \\
\hline 45 & - & 310 \\
\hline 50 & - & 300 \\
\hline 55 & - & 295 \\
\hline 60 & - & 290 \\
\hline 90 & - & 265 \\
\hline 43200 & - & 255 \\
\hline $24 \mathrm{~h}$ & - & 250 \\
\hline \multicolumn{3}{|l|}{ Ensaio 3} \\
\hline $\begin{array}{l}\text { Tempo } \\
\text { (min) }\end{array}$ & $\begin{array}{l}\text { Lodo de Sulfato de Alumínio } \\
(\mathrm{ST}=7,6 \%)\end{array}$ & $\begin{array}{l}\text { Lodo de PACl } \\
(\mathrm{ST}=0,04 \%)\end{array}$ \\
\hline 0 & 1000 & 1000 \\
\hline 5 & 995 & 1000 \\
\hline 10 & 995 & 1000 \\
\hline 15 & 960 & 1000 \\
\hline 20 & 800 & 1000 \\
\hline 25 & 670 & 1000 \\
\hline 30 & 550 & 1000 \\
\hline 35 & 460 & 995 \\
\hline 40 & 390 & 995 \\
\hline 45 & 320 & 995 \\
\hline 50 & 240 & 995 \\
\hline 55 & 190 & 995 \\
\hline 60 & 100 & 995 \\
\hline 120 & 50 & 950 \\
\hline \multicolumn{3}{|l|}{ Ensaio 4} \\
\hline $\begin{array}{c}\text { Tempo } \\
\text { (min) }\end{array}$ & $\begin{array}{l}\text { Lodo de Sulfato de Alumínio } \\
(\mathrm{ST}=0,76 \%)\end{array}$ & $\begin{array}{l}\text { Lodo de PACl } \\
(\mathrm{ST}=0,26 \%)\end{array}$ \\
\hline 5 & 1000 & 1000 \\
\hline 10 & 1000 & 1000 \\
\hline 15 & 350 & 800 \\
\hline 20 & 290 & 505 \\
\hline 25 & 260 & 100 \\
\hline 30 & 250 & 60 \\
\hline 45 & 210 & 50 \\
\hline 60 & 190 & 50 \\
\hline 120 & 160 & $<50$ \\
\hline
\end{tabular}


Tabela A6 - Variação dos valores absolutos de volume acumulado e percentuais por volume aplicado para cada ensaio de desaguamento realizado com lodos de sulfato de alumínio e de $\mathrm{PACl}$.

\begin{tabular}{|c|c|c|c|c|}
\hline Ensaio 1 & \multicolumn{4}{|c|}{ Volume aplicado de amostras de lodo $=25 \mathrm{~L}$} \\
\hline \multirow[b]{2}{*}{$\begin{array}{l}\text { Tempo } \\
\text { (min) }\end{array}$} & \multicolumn{2}{|c|}{$\begin{array}{l}\text { Lodo de sulfato de alumínio } \\
(\mathrm{ST}=2,6 \%)\end{array}$} & \multicolumn{2}{|c|}{$\begin{array}{c}\text { Lodo de PACl } \\
(\mathrm{ST}=1,4 \%)\end{array}$} \\
\hline & $\begin{array}{l}\text { Volume } \\
\text { acumulado } \\
(\mathrm{mL})\end{array}$ & $\begin{array}{l}\text { Vol. Acumulado/Vol. } \\
\text { Aplicado } \\
(\%)\end{array}$ & $\begin{array}{l}\text { Volume } \\
\text { acumulado } \\
(\mathrm{mL})\end{array}$ & $\begin{array}{l}\text { Vol. Acumulado/Vol. } \\
\text { Aplicado } \\
(\%)\end{array}$ \\
\hline 0 & 0 & 0,0 & 0 & 0,0 \\
\hline 2 & 1800 & 7,2 & 6000 & 24,0 \\
\hline 12 & 5200 & 20,8 & 9000 & 36,0 \\
\hline 42 & 7400 & 29,6 & 16000 & 64,0 \\
\hline 60 & 9250 & 37,0 & 17950 & 71,8 \\
\hline 180 & 15250 & 61,0 & 18350 & 73,4 \\
\hline 240 & 17250 & 69,0 & 18385 & 73,5 \\
\hline 300 & 18650 & 74,6 & 18495 & 74,0 \\
\hline Ensaio 2 & \multicolumn{4}{|c|}{ Volume aplicado de amostras de lodo $=20 \mathrm{~L}$} \\
\hline \multirow{2}{*}{$\begin{array}{l}\text { Tempo } \\
(\mathrm{min})\end{array}$} & \multicolumn{2}{|c|}{ Não tem amostra } & \multicolumn{2}{|c|}{$\begin{array}{l}\text { Lodo de } \mathrm{PACl} \\
(\mathrm{ST}=0,22 \%)\end{array}$} \\
\hline & $\begin{array}{l}\text { Volume } \\
\text { acumulado } \\
(\mathrm{mL})\end{array}$ & $\begin{array}{c}\text { Vol. Acumulado/Vol. } \\
\text { Aplicado } \\
(\%)\end{array}$ & $\begin{array}{c}\text { Volume } \\
\text { acumulado } \\
(\mathrm{mL})\end{array}$ & $\begin{array}{l}\text { Vol. Acumulado/Vol. } \\
\text { Aplicado } \\
(\%)\end{array}$ \\
\hline 0 & & & 0 & 0,0 \\
\hline 0,5 & & & 0 & 0,0 \\
\hline 2 & & & 4615 & 23,1 \\
\hline 4 & & & 8145 & 40,7 \\
\hline 7 & & & 11600 & 58,0 \\
\hline 15 & & & 14600 & 73,0 \\
\hline 30 & & & 14600 & 73,0 \\
\hline 60 & & & 16000 & 80,0 \\
\hline Ensaio 3 & \multicolumn{4}{|c|}{ Volume aplicado de amostras de lodo $=8 \mathrm{~L}$} \\
\hline \multirow[b]{2}{*}{$\begin{array}{l}\text { Tempo } \\
(\mathrm{min})\end{array}$} & \multicolumn{2}{|c|}{$\begin{array}{c}\text { Lodo de sulfato de alumínio } \\
(\mathrm{ST}=7,6 \%)\end{array}$} & \multicolumn{2}{|c|}{$\begin{array}{c}\text { Lodo de } \mathrm{PACl} \\
(\mathrm{ST}=0,04 \%)\end{array}$} \\
\hline & $\begin{array}{l}\text { Volume } \\
\text { acumulado } \\
(\mathrm{mL})\end{array}$ & $\begin{array}{c}\text { Vol. Acumulado/Vol. } \\
\text { Aplicado } \\
(\%)\end{array}$ & $\begin{array}{l}\text { Volume } \\
\text { acumulado } \\
(\mathrm{mL})\end{array}$ & $\begin{array}{c}\text { Vol. Acumulado/Vol. } \\
\text { Aplicado } \\
(\%)\end{array}$ \\
\hline 0 & 0 & $\mathbf{0}$ & 0 & 0 \\
\hline 0,5 & 300 & 3,8 & 5000 & 62,5 \\
\hline 1 & 600 & 7,5 & 6800 & 85,0 \\
\hline 5 & 850 & $\mathbf{1 0 , 6}$ & 7550 & 94,4 \\
\hline 15 & 1250 & 15,6 & 7600 & 95,0 \\
\hline 30 & 1550 & 19,4 & 7650 & 95,6 \\
\hline 60 & 2000 & 25,0 & & \\
\hline 120 & 2475 & 30,9 & & \\
\hline 180 & 2925 & 36,6 & & \\
\hline 240 & 3150 & 39,4 & & \\
\hline 300 & 3325 & 41,6 & & \\
\hline 480 & 3925 & 49,1 & & \\
\hline
\end{tabular}




\begin{tabular}{|c|c|c|c|c|}
\hline Ensaio 4 & \multicolumn{4}{|c|}{ Volume aplicado de amostras de lodo $=55 \mathrm{~L}$} \\
\hline \multirow{2}{*}{$\begin{array}{l}\text { Tempo } \\
(\mathrm{min})\end{array}$} & \multicolumn{2}{|c|}{$\begin{array}{l}\text { Lodo de sulfato de alumínio } \\
(\mathrm{ST}=0,76 \%)\end{array}$} & \multicolumn{2}{|c|}{$\begin{array}{l}\text { Lodo de } \mathrm{PACl} \\
(\mathrm{ST}=0,0,26 \%)\end{array}$} \\
\hline & $\begin{array}{c}\text { Volume } \\
\text { acumulado } \\
(\mathrm{mL})\end{array}$ & $\begin{array}{c}\text { Vol. Acumulado/Vol. } \\
\text { Aplicado } \\
(\%)\end{array}$ & $\begin{array}{c}\text { Volume } \\
\text { acumulado } \\
(\mathrm{mL})\end{array}$ & $\begin{array}{c}\text { Vol. Acumulado/Vol. } \\
\text { Aplicado } \\
(\%)\end{array}$ \\
\hline 0 & 0 & 0 & 0 & 0,0 \\
\hline 1 & 13500 & 24,5 & 20800 & 37,8 \\
\hline 5 & 18700 & 34,0 & 35800 & 65,1 \\
\hline 10 & 23200 & 42,2 & 41000 & 74,5 \\
\hline 15 & 26400 & 48,0 & 44500 & 80,9 \\
\hline 30 & 31200 & 56,7 & 49500 & 90,0 \\
\hline 60 & 36800 & 66,9 & 52500 & 95,5 \\
\hline 120 & 42300 & 76,9 & - & - \\
\hline 180 & 45400 & 82,5 & - & - \\
\hline 240 & 47400 & 86,2 & - & - \\
\hline 300 & 48200 & 87,6 & \begin{tabular}{l|l}
- & \\
\end{tabular} & - \\
\hline Ensaio 5A & \multicolumn{4}{|c|}{ Volume aplicado de amostras de lodo $=8 \mathrm{~L}$} \\
\hline \multirow{2}{*}{$\begin{array}{l}\text { Tempo } \\
(\mathrm{min})\end{array}$} & \multicolumn{2}{|c|}{$\begin{array}{l}\text { Lodo de sulfato de alumínio } \\
(\mathrm{ST}=2,7 \%)\end{array}$} & \multicolumn{2}{|c|}{$\begin{array}{l}\text { Lodo de PACl } \\
(\mathrm{ST}=0,28 \%)\end{array}$} \\
\hline & $\mathrm{V}$ acumul. & $\begin{array}{c}\% \text { Vol. } \\
\text { Acumulado }\end{array}$ & V acumul. & $\begin{array}{c}\% \text { Vol. } \\
\text { Acumulado }\end{array}$ \\
\hline 0 & 0 & 0 & 0 & 0,0 \\
\hline 0,5 & 400 & 5,0 & 4600 & 57,5 \\
\hline 1 & 800 & 10,0 & 6400 & 80,0 \\
\hline 3 & 1180 & 14,8 & 7400 & 92,5 \\
\hline 5 & 1480 & 18,5 & 7650 & 95,6 \\
\hline 10 & 2030 & 25,4 & 7650 & 95,6 \\
\hline 15 & 2480 & 31,0 & - & - \\
\hline 30 & 3410 & 42,6 & - & - \\
\hline 60 & 4410 & 55,1 & - & - \\
\hline 120 & 4650 & 58,1 & - & - \\
\hline Ensaio 5B & \multicolumn{4}{|c|}{ Volume aplicado de amostras de lodo $=8 \mathrm{~L}$} \\
\hline \multirow{2}{*}{$\begin{array}{l}\text { Tempo } \\
(\mathrm{min})\end{array}$} & \multicolumn{2}{|c|}{$\begin{array}{l}\text { Lodo de sulfato de alumínio } \\
(\mathrm{ST}=4,2 \%)\end{array}$} & \multicolumn{2}{|c|}{$\begin{array}{c}\text { Lodo de } \mathrm{PACl} \\
(\mathrm{ST}=0,21 \%)\end{array}$} \\
\hline & V acumul. & $\begin{array}{l}\% \text { Vol. } \\
\text { Acumulado }\end{array}$ & V acumul. & $\begin{array}{c}\% \text { Vol. } \\
\text { Acumulado }\end{array}$ \\
\hline 0 & 0 & 0 & 0 & 0,0 \\
\hline 0,5 & 300 & 3,8 & 3000 & 37,5 \\
\hline 1 & 500 & 6,3 & 5000 & 62,5 \\
\hline 3 & 950 & 11,9 & 7000 & 87,5 \\
\hline 5 & 1250 & 15,6 & 7700 & 96,3 \\
\hline 10 & 1530 & 19,1 & 7700 & 96,3 \\
\hline 15 & 1880 & 23,5 & - & - \\
\hline 30 & 2580 & 32,3 & - & - \\
\hline 60 & 3530 & 44,1 & - & - \\
\hline 120 & 3980 & 49,8 & - & - \\
\hline
\end{tabular}


Tabela A7 - Resultados dos cálculos de fluxo de umidade ou de água evaporada das amostras de lodo de sulfato de alumínio e de PACl desaguados por Leito de Drenagem - Fase de Secagem.

\begin{tabular}{|c|c|c|c|c|c|c|}
\hline \multirow{2}{*}{ Ensaio 1} & \multicolumn{3}{|c|}{ Lodo de sulfato de alumínio } & \multicolumn{3}{|c|}{ Lodo de PACl } \\
\hline & \multicolumn{3}{|c|}{ TAS $=3,43$} & \multicolumn{3}{|c|}{ TAS $=1,86$} \\
\hline Tempo & ST (\%) & $\begin{array}{c}\mathrm{Wd}=[(1 / \mathrm{ST})- \\
1] / 100\end{array}$ & $\begin{array}{c}\text { Fluxo } \mathrm{N}= \\
(\mathrm{TAS} \times \Delta \mathrm{Wd})\end{array}$ & ST (\%) & $\begin{array}{c}W d= \\
(1 / \mathrm{ST})-1\end{array}$ & $\begin{array}{c}\text { Fluxo } N= \\
\text { (TAS x } \\
\Delta \mathrm{Wd} \text { ) }\end{array}$ \\
\hline 0 & 2,59 & 10,24 & Fluxo N & 1,43 & 11,20 & \\
\hline 5 horas & 8,90 & 6,48 & 0,00 & 8,20 & 10,30 & $-1,66$ \\
\hline 1dias & 13,38 & 5,44 & $-16,32$ & 8,85 & 7,97 & $-4,33$ \\
\hline 2 dias & 15,52 & 4,96 & $-3,55$ & 11,15 & 7,43 & $-1,01$ \\
\hline 3 dias & 16,77 & 3,29 & $-1,65$ & 11,87 & 3,41 & $-7,47$ \\
\hline 4 dias & 23,32 & 3,49 & $-5,74$ & 22,66 & 4,26 & 1,57 \\
\hline 5 dias & 22,26 & 3,23 & 0,71 & 19,03 & 3,87 & $-0,72$ \\
\hline 6 dias & 23,64 & 2,26 & $-0,90$ & 20,55 & 2,52 & $-2,50$ \\
\hline 7 dias & 30,64 & & $-3,32$ & 28,39 & & \\
\hline \multirow{2}{*}{ Ensaio 2} & \multicolumn{3}{|c|}{ Lodo de PACl } & & & \\
\hline & \multicolumn{3}{|c|}{ TAS $=\mathbf{0 , 2 3}$} & & & \\
\hline Tempo & ST (\%) & $\begin{array}{c}\mathrm{Wd}=[(1 / \mathrm{ST})- \\
1] / 100\end{array}$ & $\begin{array}{c}\text { Fluxo } \mathrm{N}= \\
(\mathrm{TAS} \times \Delta \mathrm{Wd})\end{array}$ & & & \\
\hline 0 & 0,22 & 18,61 & 0,00 & & & \\
\hline $1 \mathrm{~h}$ & 5,10 & 6,68 & $-2,74$ & & & \\
\hline 1 & 13,02 & 6,39 & $-0,07$ & & & \\
\hline 2 & 13,53 & 2,96 & $-0,79$ & & & \\
\hline 3 & 25,22 & 0,16 & $-0,64$ & & & \\
\hline 4 & 85,94 & 0,12 & $-0,01$ & & & \\
\hline 5 & 89,37 & 0,09 & $-0,01$ & & & \\
\hline 6 & 91,76 & & & & & \\
\hline
\end{tabular}




\begin{tabular}{|c|c|c|c|c|c|c|}
\hline \multirow{3}{*}{$\begin{array}{c}\text { Ensaio } 3 \\
\\
\text { Tempo }\end{array}$} & \multirow{2}{*}{\multicolumn{3}{|c|}{$\begin{array}{c}\text { Lodo de sulfato de alumínio } \\
\text { TAS }=\mathbf{7 , 3 5}\end{array}$}} & \multirow{2}{*}{\multicolumn{3}{|c|}{$\begin{array}{c}\text { Lodo de PACl } \\
\text { TAS }=\mathbf{0 , 0 4}\end{array}$}} \\
\hline & & & & & & \\
\hline & ST (\%) & $\begin{array}{l}\mathrm{Wd}=[(1 / \mathrm{ST} \\
)-1] / 100\end{array}$ & $\begin{array}{c}\text { Fluxo } \mathrm{N}= \\
(\mathrm{TAS} \times \Delta \mathrm{Wd})\end{array}$ & ST (\%) & $\begin{array}{c}\mathrm{Wd}=(1 / \mathrm{ST})- \\
1\end{array}$ & $\begin{array}{c}\text { Fluxo } \mathrm{N}= \\
(\mathrm{TAS} x \\
\Delta \mathrm{Wd})\end{array}$ \\
\hline 0 & 7,62 & 9,28 & 0,00 & 0,04 & 54,77 & 0,00 \\
\hline 0,33 & $\mathbf{9 , 7 2}$ & 4,77 & $-49,49$ & 1,79 & 6,68 & $-1,92$ \\
\hline $1 \mathrm{dia}$ & 17,33 & 3,06 & $-12,60$ & 13,02 & 0,88 & $-10,79$ \\
\hline 2 dias & 24,64 & 2,53 & $-3,86$ & 53,25 & & \\
\hline 3 dias & 28,31 & 1,80 & $-5,38$ & & & \\
\hline 4 dias & 35,71 & 1,67 & $-0,98$ & & & \\
\hline 5 dias & 37,50 & 0,07 & $-11,76$ & & & \\
\hline 6 dias & 93,70 & 0,12 & 0,42 & & & \\
\hline 7 dias & 88,90 & & & & & \\
\hline \multirow{2}{*}{ Ensaio 4} & \multicolumn{3}{|c|}{ Lodo de sulfato de alumínio } & \multicolumn{3}{|c|}{ Lodo de PACl } \\
\hline & \multicolumn{3}{|c|}{ TAS $=2,20$} & \multicolumn{3}{|c|}{ TAS $=0,76$} \\
\hline Tempo & ST (\%) & $\begin{array}{l}\mathrm{Wd}=[(1 / \mathrm{ST} \\
)-1] / 100\end{array}$ & $\begin{array}{c}\text { Fluxo } \mathrm{N}= \\
(\mathrm{TAS} \times \Delta \mathrm{Wd})\end{array}$ & ST (\%) & $\begin{array}{c}\mathrm{Wd}= \\
(1 / \mathrm{ST})-1\end{array}$ & $\begin{array}{c}\text { Fluxo } \mathrm{N}= \\
(\mathrm{TAS} \times \Delta \mathrm{Wd})\end{array}$ \\
\hline 0 & 0,76 & 6,94 & 0,00 & 0,26 & 18,61 & 0,00 \\
\hline 0,21 & 12,60 & 3,27 & $-10,21$ & 5,10 & 4,98 & $-0,55$ \\
\hline 1 dia & 23,41 & 0,81 & $-5,41$ & 16,73 & 1,15 & $-7,12$ \\
\hline 2 dias & 55,21 & 0,38 & $-0,94$ & 46,55 & & \\
\hline 3 dias & 72,31 & 0,03 & $-0,77$ & & & \\
\hline 4 dias & 96,67 & 0,07 & 0,08 & & & \\
\hline 5 dias & 93,33 & 0,02 & $-0,11$ & & & \\
\hline 6 dias & 98,10 & & & & & \\
\hline \multirow{2}{*}{ Ensaio 5A } & \multicolumn{3}{|c|}{ Lodo de sulfato de alumínio } & \multicolumn{3}{|c|}{ Lodo de PACl } \\
\hline & \multicolumn{3}{|c|}{ TAS $=2,61$} & \multicolumn{3}{|c|}{ TAS $=\mathbf{0 , 0 4}$} \\
\hline Tempo & ST (\%) & $\begin{array}{l}\mathrm{Wd}=[(1 / \mathrm{ST} \\
)-1] / 100\end{array}$ & $\begin{array}{c}\text { Fluxo } \mathrm{N}= \\
(\mathrm{TAS} \times \Delta \mathrm{Wd})\end{array}$ & ST (\%) & $\begin{array}{c}\mathrm{Wd}= \\
(1 / \mathrm{ST})-1\end{array}$ & $\begin{array}{c}\text { Fluxo } \mathrm{N}= \\
(\mathrm{TAS} \times \Delta \mathrm{Wd})\end{array}$ \\
\hline 0 & 2,66 & 4,48 & 0,00 & 0,28 & - & - \\
\hline $1 \mathrm{dia}$ & 18,26 & 2,96 & $-3,95$ & & & \\
\hline 2 dias & 25,24 & 1,51 & $-3,79$ & & & \\
\hline 3 dias & 39,81 & 1,82 & 0,81 & & & \\
\hline 4 dias & 35,44 & 1,61 & $-0,54$ & & & \\
\hline 5 dias & 38,25 & 1,10 & $-1,35$ & & & \\
\hline 6 dias & 47,67 & 0,99 & $-0,29$ & & & \\
\hline 7 dias & 50,30 & & & & & \\
\hline
\end{tabular}




\begin{tabular}{|c|c|c|c|c|c|c|}
\hline \multirow{2}{*}{ Ensaio 5B } & \multicolumn{3}{|c|}{ Lodo de sulfato de alumínio } & \multicolumn{3}{|c|}{ Lodo de PACl } \\
\hline & \multicolumn{3}{|c|}{$\mathrm{TAS}=4,19$} & \multicolumn{3}{|c|}{ TAS $=0,27$} \\
\hline Tempo & ST (\%) & $\begin{array}{c}\mathrm{Wd}=[(1 / \mathrm{ST} \\
)-1] / 100\end{array}$ & $\begin{array}{c}\text { Fluxo } \mathrm{N}= \\
(\mathrm{TAS} \times \Delta \mathrm{Wd})\end{array}$ & ST (\%) & $\begin{array}{c}\mathrm{Wd}= \\
(1 / \mathrm{ST})-1\end{array}$ & $\begin{array}{c}\text { Fluxo } \mathrm{N}= \\
(\mathrm{TAS} \times \Delta \mathrm{Wd})\end{array}$ \\
\hline 0 & 4,19 & 22,85 & 0,00 & 0,21 & - & - \\
\hline 1 dia & 14,49 & 5,90 & 0,00 & & & \\
\hline 2 dias & 20,50 & 3,88 & $-8,21$ & & & \\
\hline 3 dias & 25,35 & 2,95 & $-3,79$ & & & \\
\hline 4 dias & 38,52 & 1,60 & $-5,48$ & & & \\
\hline 5 dias & 33,32 & 2,00 & 1,65 & & & \\
\hline 6 dias & 28,54 & 2,50 & 2,04 & & & \\
\hline 7 dias & 42,35 & & & & & \\
\hline
\end{tabular}

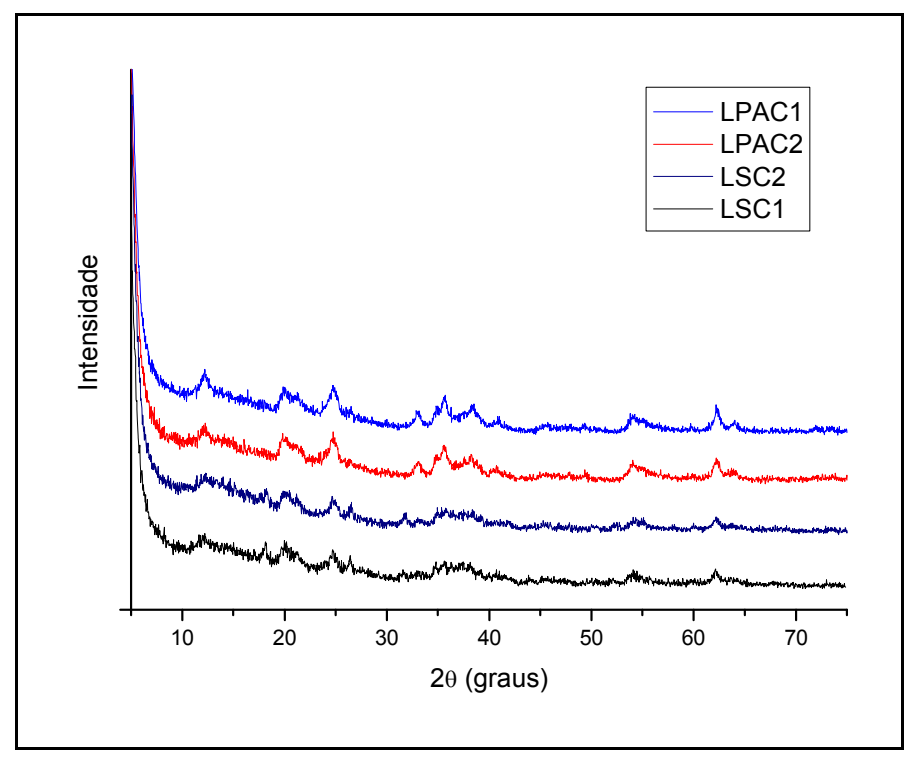

Figura A1 - Difratograma de raios $\mathrm{X}$ das amostras de lodo de sulfato de alumínio bruto (LSC1) e lodo desaguado (LSC2) e amostras de lodo de PAC $\boldsymbol{\ell}$ bruto (LPAC1) e lodo desaguado (LPAC2). 